
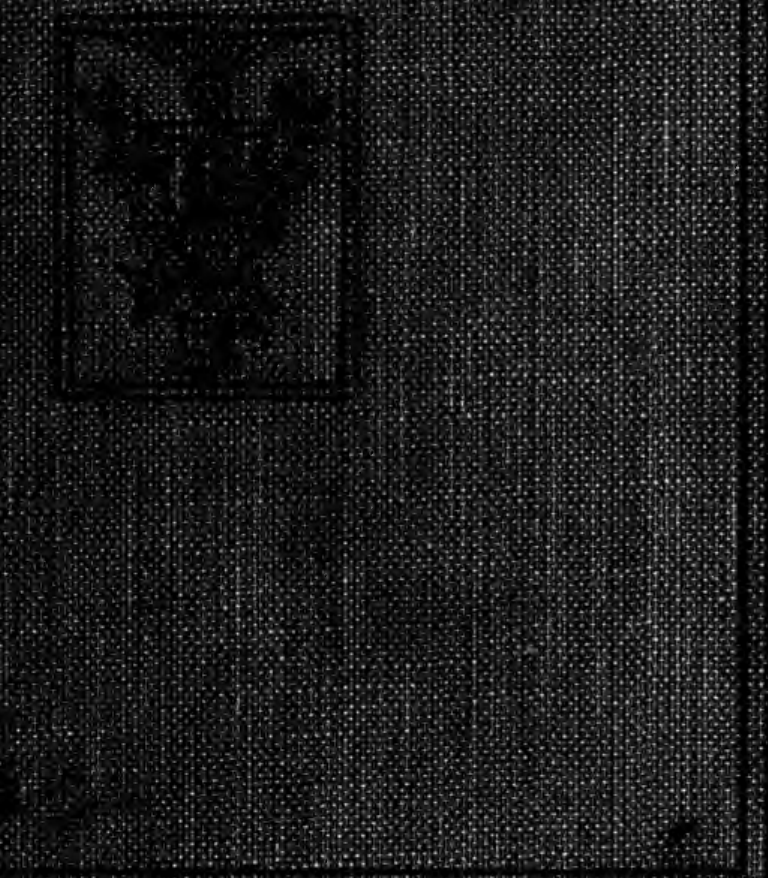

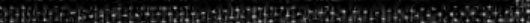



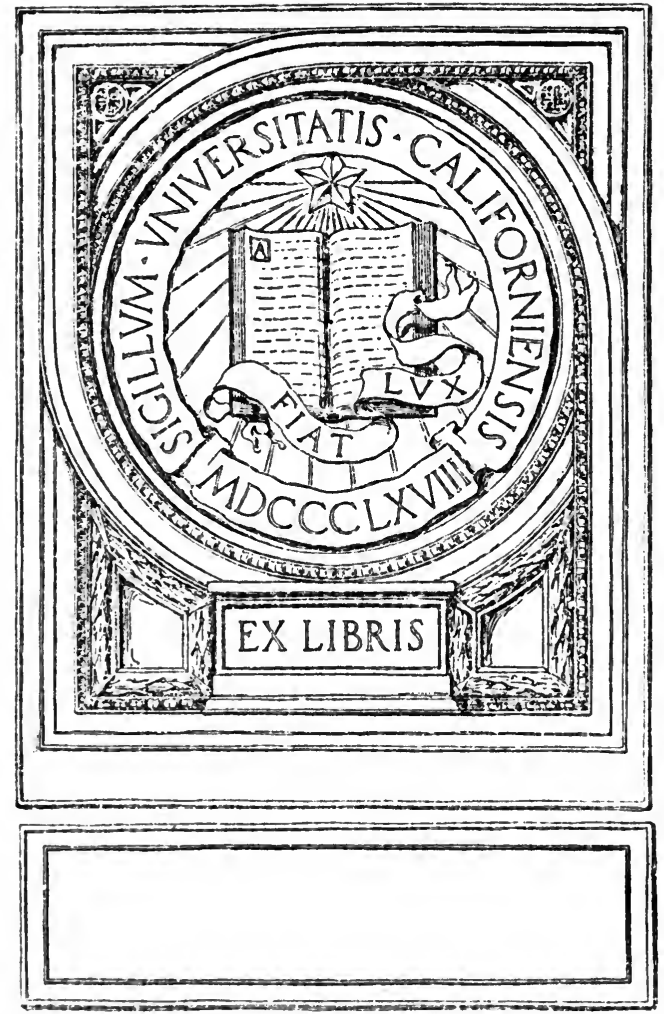


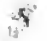




\section{Digitized by the Internet Archive in 2007 with funding from Microsoft Corporation}


BELL'S GEOGRAPHICAL SERIES

Edited by Al.bert Wilmore, D.Sc.(Lond.), F.G.S.

\section{THE GROUNDWORK OF MODERN GEOGRAPHY}




\section{BELL'S GEOGRAPHICAI, SERIES}

EDITED BY

ALBERT WILMORE, D.Sc.(Lond.), F.G.S.

THE BRITISH EMPIRE BEYOND THE SEAS An Introduction to World Geography. By MARION I. Newbigin, D.Sc.(Lond.). With upwards of 30 Maps. Third Edition. Crown 8vo, 4s. 6d.

THE GROUNDWORK OF MODERN GEOGRAPHY.

An Introduction to the Science of Geography. By Albert Wilmore, D.Sc.(Lond.), F.G.S.

Other Volumes in preparation.

LONDON: G. BELL AND SONS LTD. 


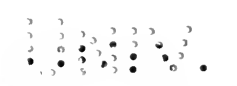




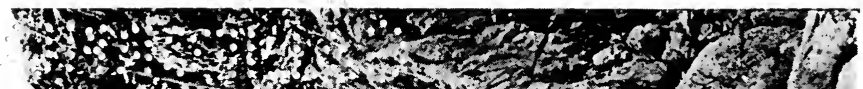

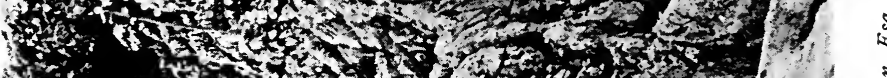
10. if

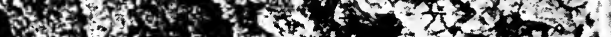

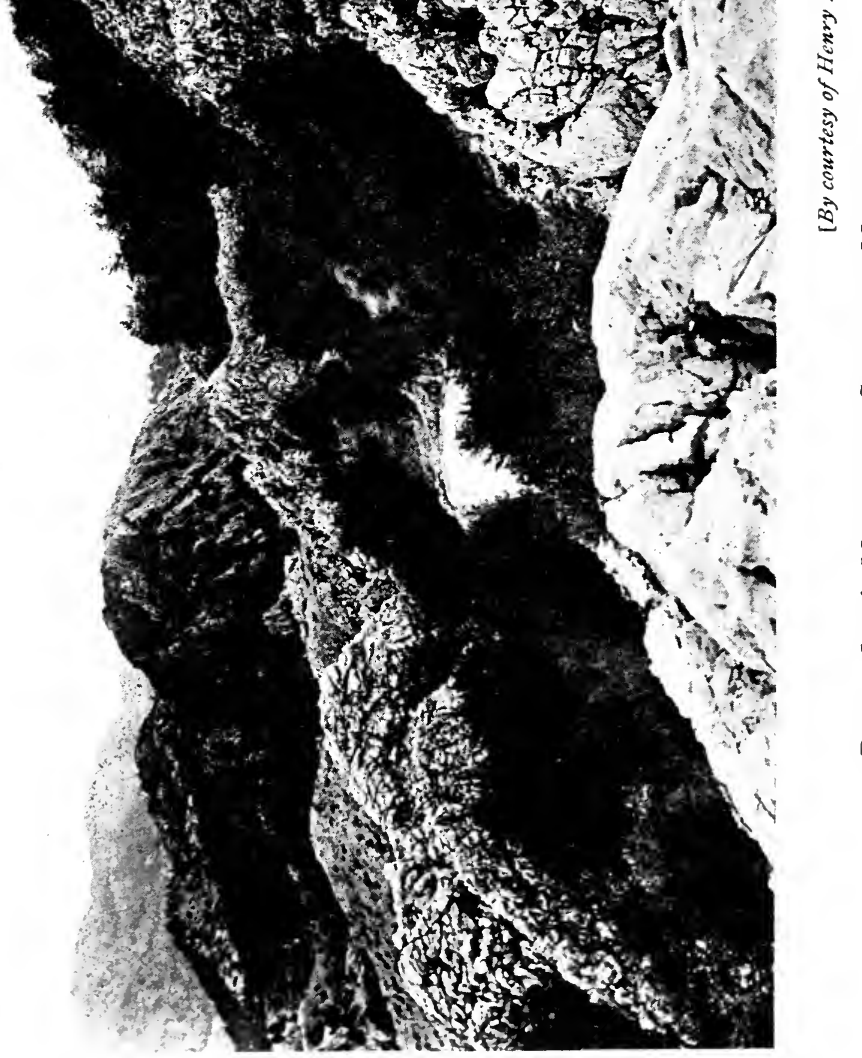

(2)

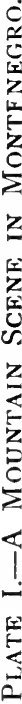




\title{
THE GROUNDWORK OF
}

\section{MODERN GEOGRAPHY}

\author{
AN INTRODUCTION TO \\ THE SCIENCE OF GEOGRAPHY
}

BY

ALBERT WILMORE, D.Sc.(Lond.), F.G.S. ASSISTANT MASTER, MANCHESTER GRAMMAR SCHOOL.

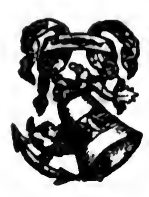

LONDON

G. BELL AND SONS LTD.

I 920 
$7 D^{55}$
$V^{5}$

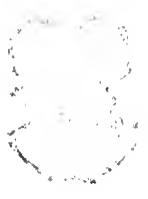

Ii... 


\section{TO HIS FRIEND}

A. L. T.

THE AUTHOR INSCRIBES THIS BOOK IN GRATEFUL ACKNOWLEDGMENT OF MUCH SYMPATHY AND HELP IN HIS WORK AS A TEACHER OF GEOGRAPHY 



\section{P R E F A C E}

THE writer of a book on Geography can scarcely hope to be really original ; but every writer or teacher may emphasise those parts of the science which appeal most strongly to him, or which seem to him to be most important. In this book the author has exercised this privilege freely, and has followed what appears to him to be a natural sequence. It is perfectly obvious, however, that other writers may prefer a different order, and may choose to emphasise other aspects of this wide science.

Limits of space have necessitated the sacrifice of Mathematical Geography and Cartography, and the important branch Oceanography is only incidentally mentioned. The author has had in view a book which may provide, within moderate compass, an introduction to the so-called "New Geography." It is hoped that not only the student but also the intelligent general reader may find the book of some interest, and that it may serve as a preparation for, and a stimulus to, the reading of one or more of the excellent monographs or "Regional Geographies" now available in English. The admirable series "The Regions of the World," edited by Mr. Mackinder, and the stimulating " Europe," by Prof. Lyde, may be mentioned as examples of books to which the present "groundwork" may possibly serve as an introduction. 
The writer has had no special syllabus in mind while writing the book, nor does it claim to be peculiarly adapted to any examination, but it is hoped that students reading for the following examinations may find it useful :-The Oxford and Cambridge Senior Locals and Higher Locals; the Matriculation and Intermediate Examinations of the Universities; the Preliminary Certificate and Certificate Examinations of the Board of Education; and the Examinations in Geography set by the Civil Service Commissioners.

It is impossible for a writer in Geography to express or even to know how much he owes to his predecessors. The present writer freely acknowledges his great indebtedness to many well-known teachers and writers. Among the present-day Geologists who have exercised a great influence on Geography, he would especially mention Prof. G. A. J. Cole and Prof. J. W. Gregory, to whose writings all geographers are so much indebted. Other Geologists who have exercised a great influence on the teaching of Physical Geography within the present generation are Sir A. Geikie, the late Prof. James Geikie, the late Prof. Judd, Canon Bonney, Dr. Marr, and Prof. Garwood. Every Geographer of to-day must be familiar with much that they have written. The writings of some famous American Geologists are mentioned in the Bibliographies at the ends of chapters.

Among the Geographers who are not usually regarded as Geologists, Mr. Mackinder, Prof. Lyde, Dr. Mill, Mr. Chisholm, and the late Prof. Herbertson have been our masters, and no one who teaches Geography can be guilty of over-rating the debt our modern science owes to them. The author would especially mention. the name of Prof. Wm. M. Davis, the distinguished American geographer, whose work and influence 
reaches to the utmost limits of modern geographical teaching. To all these the present writer expresses his obligations.

Many friends have kindly furnished illustrations for this work ; these are acknowledged in the Text. Illustrations have, however, been used somewhat sparingly, so as to keep the book within moderate compass. The maps are quite simple and are such as the student may readily draw for himself.

Mr. A. N. Wilmore, formerly of St. John's College, Cambridge, has greatly helped by reading the proof sheets.

It goes without saying that the reader must always have the Atlas at his elbow; to read the book without the constant help of an atlas would be of very little value.

The Examination Questions at the end of the book are reproduced by kind permission of the various examination bodies mentioned below, to whom I express my grateful acknowledgments :-

The Delegates of the Local Examinations, University of Oxford.

The Local Examinations and Lectures Syndicate, University of Cambridge.

The Senate of the University of London.

The Joint Matriculation Board of the Universities of Manchester, Liverpool, Leeds, and Sheffield.

The Controller of His Majesty's Stationery Office. 


\section{CONTENTS}

PAGE

INTRODUCTION

\section{SECTION A}

THE STRUCTURE OF THE EARTH'S SURFACE,

OR THE PRINCIPLES OF STRLCTURAL GEOGRAPHY

CHAP

I. ThE MATERIALS OF WhICH THE EARTH'S CRUST

IS $M$ I A •

II. LAND-FORMS $\quad$ - $\quad$ - $\quad$ - 22

III. Land-Forms (Continued). Volcanoes axd Vol-

Canic Mountains • • • • . 43

IV. LAND-Foris (Continued). Residual Mountains 58

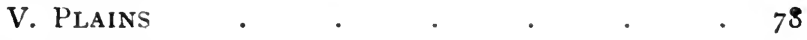

VI. VAlleys AND Basins . . . . 102

VII. Lakes and LaKe Basins . . . . . 117

VIII. Coast-Lines and Inlets of the SEa . - I33

IX. Economic Geography of the Rocks • • 156

X. Economic Geography of the Rocks (Contd.) 178 $\mathrm{xi}$ 


\section{SECTION B}

THE PRINCIPLES OF CLIMATIC GEOGRAPHY CHAP.

XI. The Atmosphere. Winds, Rainfall, and TEMPERATURE

Xil. Some Concrete Studies in Climate . 210

\section{SECTION C}

\section{BIOLOGICAL GEOGRAPHY}

XIII. Plant Geography $\quad$ • $\quad$ • 243

XIV. Plants and Plant-Products of Economic I IIPORTANCE . . . . . 262

XV. Plants of Economic Importance (Continued) 290

XVI. Geographical Distribution of Animals • 307 XVII. MAN ON THE EARTH . . . . 324 XVIII. The Distribution of Population and the LOCATION OF TOWNS $\quad \cdot \quad \cdot 338$

\section{APPENDIX}

QUESTIONS SELECTED FROM THE EXAMINATION PAPERS IN GEOGRAPHY SET BY VARIOUS WELLKNOWN EXAMINING BODIES . . . 353

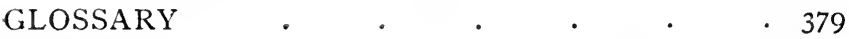

INDEX $\quad . \quad+\quad . \quad \cdot \quad \cdot \quad \cdot 385$ 


\section{LIST OF PLATES}

PLATE

I. A Mountain Scene in Montenegro . Frontispiece By courtesy of Hexky Hewitt-Deas, Esq., J.P.

FACING PAGE

II. Mythen, OVERLCOKING LAKE LUCERne - 30 .

III. Rosentaui, Wellhorn, AND Wetterhorn (Bernese Obertand) • • • • • $3 \mathrm{I}$

IV. "The Remarkables," Alpine Mountains, South ISLAND, NEW ZEaland • . 32

By courtesy of the $\mathrm{H}$ gh Commissioner for New Zealand.

V. View of the Rocky Mountains in Alberta

By courtesy of the High Commissioner for Caneda.

Vi. The Tarim River, Central Asia ; an "Inter.-

Nal Drainage" River . . . . 38 Reproduced from Central. Asia, by Dr. Sren HediN.

ViI. Parasitic Cones in Eruption, Mount Etna •: 48

Vili. Kilanea, the Seconi Crater of Mauna loa, SANDWICH ISLANDS, THE WORLD'S LARGEST Volcano $\therefore 49$

IX. INGleborough SEen fron the West . • 66 xiii 
X. A Mountain of Horizontal Torridon SandSTONE, ENCLOSING A MOUNTAIN OF LEWISIAN GNEISS

Photo by Geological Survey.

XI. The Via Mala, a Typical Transverse Gorge in THE RHAETIAN AlpS . . . II3

XII. Marjeelen See and Aletsch Glacier . 120

XiII. Alluvial Flat between Lakes DerwentWATER AND BASSENTHWAITE, ENGlish LAKE DISTRICT . . . .

By courtesy of J. Ravson, Esq., F.G.S.

XIV. A FIORD IN NEW ZEALAND: "Milford

Sound," NEIV ZEALAND . •
By courtesy of the High Commissioner for New Zealand.

XV. The Bocche di Cattaro, the Fanous ComPLEX OPENING IN THE "BlaCK MOUNTAINS"

XVI. Dissected Coast in Cornwall, Shoiving EROSION

XVII. A SubMerged Forest at Leasowe, in ChESHIRE . . . . . I5I By courtesy of J. RANson, Esq., F.G.S.

XVIII. Tropical Forest, Congo Basin, SHOWING Rich UNDERgRowth aNd Parasitic CREePERS • . . . . . 244

XIX. Sandwich Islands. An Hawailan Sugar Plantation . $\quad$. $\quad$. 245 
PLATE

FACING PAGE

XX. Coco-nut Palms, Ceylon

278

XXI. Cotron Picking, South-EAsteri United States

XXII. Olives at Falicon, above Nice * . 282

XXIII. A Canadian Wheatfield

By courtesy of the Canadian Pacific Railway Co.

XXIV. The Canel, the Animal of the Desert, AND ITS ENVIRONMENT . . . 3 IO

XXV. The AMerican Bison (or Buffalo), bos Americanus, Wainwright National Park. A Typical Prairie Animal - 3i I

XXVI. Characteristic Arctic Upland Scene: A HERD OF REINDEER, NORTHERN SCANDINAVIA. - 317

XXVII. Implenents of the Stone Age . From Specimens in the Pritish Museum. 



\section{THE GROUNDWORK OF MODERN GEOGRAPHY}

\section{INTRODUCTION}

GEOGRAPHY is the science which describes the relief of the earth's surface, and which deals with the phenomena taking place upon that surface. The strict etymology of the word Geography (ge, the earth; grapho, I write or describe) might appear to limit it to a mere description, but by almost universal consent the science now includes not only a description of the surface forms of the earth's crust, but investigates and describes phenomena and endeavours to explain results.

It is a composite and synthetic science, relying for its data on the more distinctive or specialised sciences, such as astronomy, geology, meteorology, and biology. There is no definite limit between astronomy and geography, or between geology and geography. On the other side, history and geography have much ground in common. The science is as composite in character as it is synthetic in its relationships, and consequently contains many interrelated and well-understood subdivisions. Dr. H. R. Mill, in the stimulating Introduction to The International Geography, edited by him, gives a graphical representation of the departments of this synthetic science, and their relation to each other. Geography he represents as a pyramid with a broad 
base of Mathematical Geography. On this rests Physical Geography, and on this again Biological Geography. Anthropogeography rests on Biological Geography, and the apex of the pyramid is Political Geography.

It is obvious that in such a synthetic and composite science different writers and teachers may attach different degrees of importance to the various branches of the subject. In the present volume, Geography is especially regarded as the science which deals with the earth's surface as the home of man. The various surfaceforms and the rock-contents very largely limit and determine man's varied activities; and to these must be added the factors of climate, which constitute another phase of man's " physical environment." The distribution of the ordinary animal and plant life is more regularly limited and controlled by surface-form and climate, but man has learnt to react upon and control his environment, and to combat his limitations.

The book begins, therefore, with Structural GeoGRAPHY, including in this an account of surface-forms and rock-contents, and then passes on to the elements of Cimatic Geography. Biological Geography follows naturally after these, and the Geography of Man (ANTHROPOGEOGRAPHY) falls in its place at the end of this branch of the science. The last chapters contain brief considerations of some aspects of Political and EcoNOMIC GEOGRAPHY, these obviously being only particular aspects of human geography. 


\title{
SEGTIONA
}

\section{THE STRUCTURE OF THE EAR'TH'S SURFACE, OR THE PRINCIPLFS OF STRUCTURAL GEOGRAPHY}

\author{
C H A P T E R I
}

THE MATERIALS OF WHICH THE EARTH'S CRUST IS MADE

THE earth, on whose surface we live, is almost spheroidal in shape. This globe has an irregular surface, which is partly covered by water and wholly by the atmosphere. The surface, and a very slight distance below, are the only parts which are accessible to man and which he can directly study by experiment and observation. The diameter of the earth is about 8000 miles; the thin surface layer which man has been able to study directly is not more than Io miles in thickness at the most. The borings which have been made in search of coal, or metals, or water, are the merest pin-pricks in the great globe.

This comparatively thin outer crust is of very great importance to man, however, not only because he lives on it, but because its nature and contents influence him at every point. It consists of different kinds of rocks, 
and hence is known as the crust of the lithosphere ${ }^{\mathbf{1}}$; the covering of air and the partial covering of water are known as the atmosphere and the hydrosphere ${ }^{1}$ respectively.

The rocks of the crust may be seen by removing the superficial covering of vegetation and soil ; they may be studied in sea-cliffs and river-cuttings, in many a hillside and mountain scarp, and in excavations made by man for various purposes. By comparing the rocks in different exposures it is seen that there is a great variety of them; in one place the rock may be hard granite, in another soft white chalk, in another fissile shale or slate. The geographer soon realises that the whole character of a region depends very largely upon the rocks which occur at the surface, and it is obviously desirable that he should know something of the origin and classification of these rocks.

The intimate study of the nature and origin of rocks and the method of their classification is a branch of the science of Geology. Rocks will be studied here more from a geographical than from a geological point of view, borrowing from the latter science just as much as may enable the student to understand how the varied features of the earth's surface "depend upon the nature and position of the rocks.

Sedimentary Rocks. - The most cursory examination of many rocks shows them to be similar in composition and in general character to the deposits which are now being formed in shallow seas, and especially in gulfs and estuaries and lakes. Thus the gravel beds of Blackheath are very similar to the gravels or pebblebeds seen on many parts of the sea-coast. The sandstones which form so large a part of the Pennines are in general composition quite like the deposits of the

${ }^{1}$ Greek: lithos, a stone; atmos,' the air; hydor, water; and sphaira, a sphere. 
shallower parts of such an estuary as the Dee, or Morecambe Bay, or Solway Firth. The clays of the "Clayvale," which extends diagonally across England from Oxford to the Wash, are very similar to the muds formed in the estuaries of some of the larger rivers of Western Europe.

All such rocks consist for the most part of material which has been worn from pre-existing rocks by the ordinary processes of erosion, chiefly by frost, rain, and rivers, and by the sea. They are called Sedimentary ${ }^{1}$ from the way in which the material has been deposited. They are also known as Aqueous, because they have been deposited in water usually. The names Aqueous and Sedimentary are not strictly interchangeable, however, as some sedimentary rocks are wind-formed. This is the case with many desert sands, which largely consist of particles detached from rocks by great and sudden changes of temperature. In deserts small rock fragments may be driven by the prevalent, steady winds for great distances, and immense deposits of such sands are found in and near many of our tropical and sub-tropical deserts. The Loess of China-a deposit which has a maximum thickness of over 3000 feet -is clearly sedimentary, but it is not aqueous as a rule. It is probably for the most part wind-borne, and consists of fine rock-dust blown outwards from the middle of the great Eurasian continent by the winds which blow with such regularity from the regions of winter high pressure.

It is quite obvious, too, that mingled with the mud and sand deposited in shallow seas, there will be many kinds of remains of organisms, especially of those with hard parts which are not dissolved readily, such as corals, crinoids, and mollusca. Under certain circum-

1 Latin: sedeo, sedere, to sit, to settle. Latin noun, sedimentum. 
stances, and more especially in the warmer, shallow seas, organic remains predominate over the other constituents, and an organic rock is formed, in this case called a limestone, because the organic fragments are chiefly composed of Calcium Carbonate or Carbonate of Lime $\left(\mathrm{CaCO}_{3}\right)$. On this account, limestones may be grouped with the sedimentary or aqueous rocks.

There is yet another group of rocks which may be included loosely with the above. Deposits of vegetable origin are formed, either on the land where the vegetation has grown, or in shallow lakes and lagoons into which drifted vegetation has been carried in large quantity, and where it has mingled with the aquatic vegetation of the lagoon itself. The peat of the moorlands has been formed by the long-continued death and decay of moorland vegetation, such as sphagnum or " bog-moss," sedges, rushes, ferns, and other plants. Fen-peat has been formed similarly in marshy lowlands by the accumulation of decayed vegetation such as that which grows so luxuriantly in the fen-lands of England, the Netherlands, and North-Western Germany. In a somewhat similar way coal-beds of different kinds were formed in past ages of the earth's history from different kinds of plants which then grew in great luxuriance. It is quite clear that such rocks are not strictly of the same class as sandstones and shales; they may not be, in all cases, even aqueous, but it is convenient to group them with the sedimentary and aqueous rocks for purposes of study and description.

This great class of rocks, therefore, may be classified by the geographer as follows:

\section{Sedimentary and Aqueous Rocks}

(a) Sands, sandstones, coarse sandstones or grits, consolidated pebble-beds or conglomerates. The 
rocks of this group may be termed the sandy or arenaceous sub-class.

(b) Muds, clays, shales, slates. This is the clay-shale or argillaceous sub-class.

(c) Limestones, made up chiefly of the hard calcareous parts of sea-organisms, animal, or plant (the former predominating). This is the calcareous sub-class.

(d) Rocks of vegetable origin; peat, brown-coal or lignite, coal, cannel-coal, anthracite. This is the carbonaceous sub-class.

Igneous Rocks.-This great class of rocks is quite different in origin from those considered above. The common feature of these rocks is that they have all solidified from the molten condition; but just as in the case of the sedimentary class, there are great differences in the characters of the numerous rocks included in the igneous class.

The simplest and most obvious sub-class includes those rocks which have been poured out in the molten condition from cracks and fissures in the earth's crust, or from the craters or flanks of volcanoes. These are the lavas, which, when cooled and solidified, are named volcanic rocks. Lavas vary very considerably not only in their chemical and mineralogical composition, but also in their physical properties; some are more liquid than others-they possess a lower meltingpoint, and hence when poured out on the earth's surface from a crater or fissure they flow much more perfectly and extend to a greater distance. Some lava-flows are thus of great extent while others are much more limited in area. Modern lavas from the volcanoes of Iceland have covered scores of square miles, while, on the other hand, in many parts of the world there have been poured out viscid lavas which 
have flowed very imperfectly and which have solidified somewhat after the manner of the tallow on an oldfashioned tallow candle. The outpourings of highly liquid lava are of importance to the geographer because extensive plateau areas in the Deccan of India, in South Africa, in Eastern Africa, and in the region west of the Rocky Mountains in. North America are largely occupied by these solidified fissure-lavas or plateaulavas, as they are often called.

Another type of volcanic product consists of the fragmentary material ejected in explosive outbursts; this may vary from the finest impalpable dust to large bombs or irregular fragments, and the solidified deposits thus formed may vary in texture from a finegrained " ash" to a breccia made up of large, irregular fragments. The explosive outbursts of some volcanoes, such as, for example, Vesuvius, scatter enormous quantities of such fragmentary material over the region in the immediate neighbourhood of the volcano. It was chiefly such showers of volcanic ash that buried the cities of Herculaneum, Pompeii, and Stabiæ in the classic eruptions of A.D. 79 .

It may be pointed out that some deposits formed in this manner have certain features in common with many of the sedimentary rocks already described. Submarine deposits of fragmentary volcanic matter are known which contain fossils, and stratification is often a marked feature of these "tuffs" or beds of volcanic ash. At the summit of Snowdon may be seen beds of wellstratified volcanic ash in which fossils are quite common.

In many volcanic regions these fragmentary volcanic rocks cover vast areas, and provide by their weathering a very fertile soil. They are thus of considerable interest to the geographer as well as to the geologist. In a subsequent chapter dealing with "land-forms," 
it will be shown how the familiar mountains known as volcanoes are in large measure built up of volcanic ash, breccias, and lava-flows.

Another group of igneous rocks includes those which have not a superficial origin, but which have solidified below the surface and have come within the scope of the geographer by the removal of the overlying rocks by denudation. Those which are of greatest importance are as follows:

(a) Sheet-like intrusions of molten matter, the latter having come from some subterranean source, and the intrusions having been thrust into rocks already existing, more or less along their beddingplanes or planes of stratification. 1 Such sheets are known as " sills" ; they are not easily distinguishable from lava-flows in many cases, and their geographical relationships are often very similar.

$\left(a_{1}\right)$ Intrusions having a more or less vertical direction or trend, which may be in the nature of vertical or highly inclined sheets, "pipes" of varying size and extent, which probably communicated with some deep-seated reservoir of molten rock, and which probably served as feeders for longcontinued outpourings of lava. To these may be added the solidified matter in necks and cauldrons of volcanoes from the craters of which lava was poured out and fragmentary material ejected.

(b) Large masses or bosses of varying size and shape which have solidified at somewhat greater depths within the crust; which have in consequence of their depth solidified slowly and under great pressure, and the individual constituent minerals of whose rocks have been more perfectly developed in consequence.

${ }^{1}$ Latin: stratum, a layer or bed. 
Those under $(b)$ are the sub-class known as Plutonic Rocks; those under $(a)$ and $\left(a_{1}\right)$ are generally termed Intrusive Rocks. It is not easy, in many cases, to decide whether a rock should be described as plutonic or intrusive.

In addition to differences in mode of origin Igneous Rocks may be classified according to their composition, and as the names in common use depend upon the chemical and mineral composition, it is necessary to indicate very briefly the basis of the classification. The commonest chemical compound present in igneous rocks is Silica, or oxide of silicon, $\mathrm{SiO}_{2}$. This constituent is comparatively easy to estimate by analysis, and hence it is used as a basis of classification. Those rocks which contain a very large proportion of silica are known as Acid, those with a relatively low proportion are Basic, and those with an intermediate proportion are known as Intermediate.

\section{TABle of Chief Igneous Rocks}

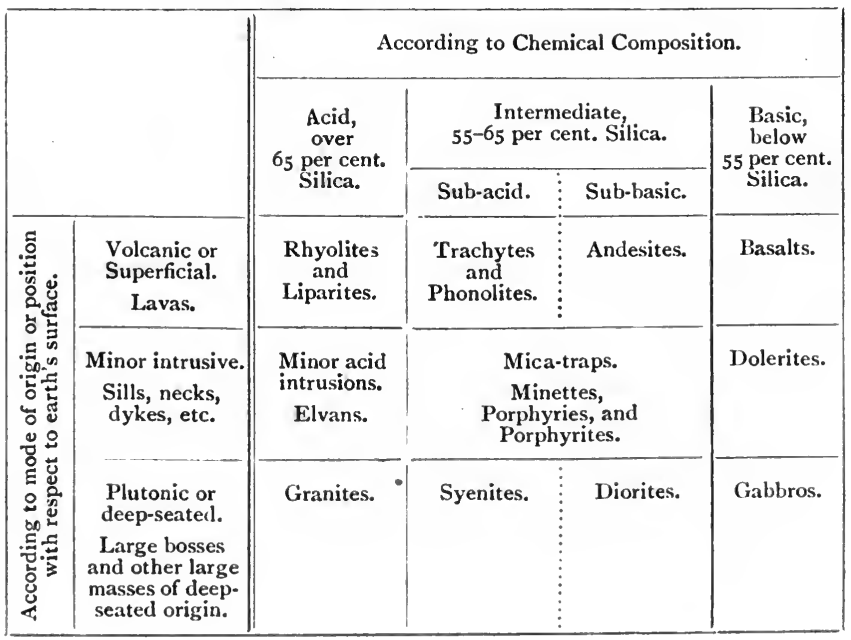




\section{MATERIALS OF EARTH'S CRUST}

Thus, by combining both the ultimate chemical composition and the mode or circumstance of origin, we may make a table which includes the best known kinds of igneous rocks, and which is sufficiently elaborate for the geographer (see opposite page).

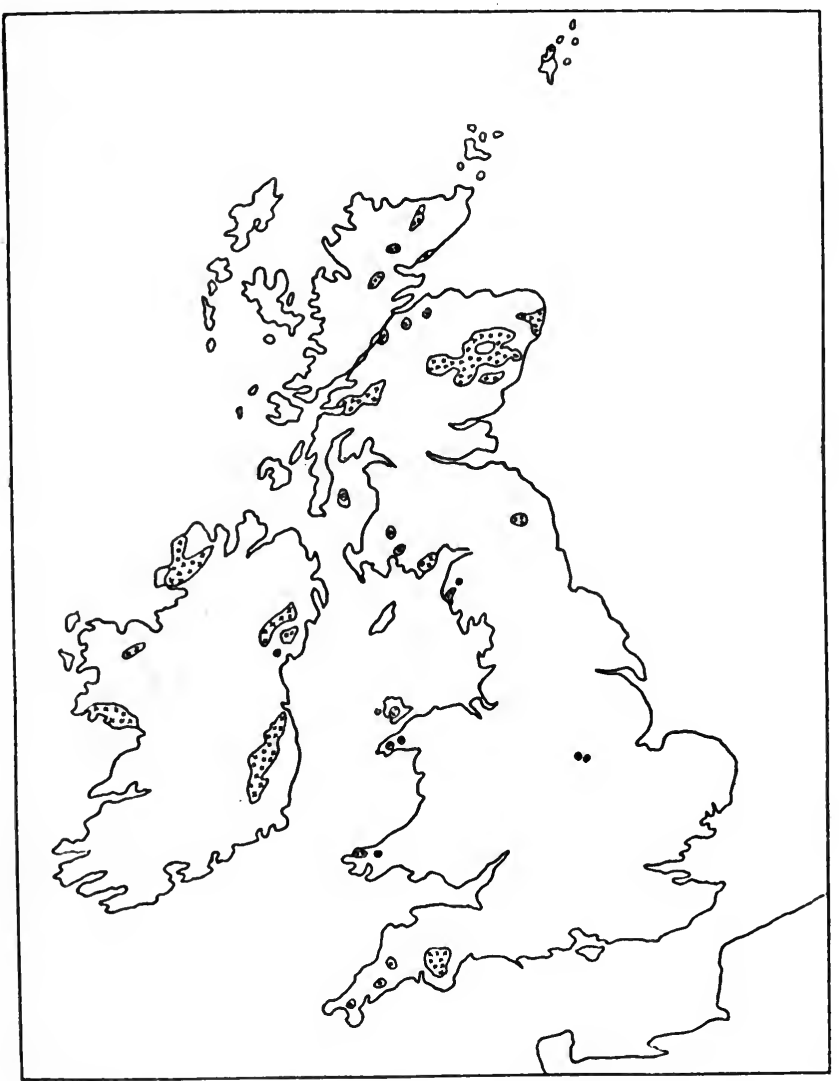

The regions where granite crops out at the surface are shown

Fig. I.-Chief Granite Areas in British Isles. 
Among the Plutonic rocks granites are the most important to the geographer, and basalts among the Volcanic rocks sub-class, because these are found in larger quantities than the other types. Granite forms the surface rock in several of the wilder mountain districts in the British Isles. This rock now appears at the surface because the rocks under which it consolidated at considerable depths have been removed by denudation. Basalt and rocks closely related to it in composition form the greater part of the volcanic plateau of Antrim, including the interesting rocks of Giant's Causeway. Fingal's Cave, in the island of Staffa, is a remnant of a similar wide sheet of basaltic rocks of the same age as those of Antrim.

Metamorphic Rocks.-The rocks of which the earth's crust is composed are always being acted upon by many natural forces and agents which produce in them some kind of change, either chemical or physical. Water penetrates those which are readily permeable, and flows along the bedding-planes and cracks of those which are less permeable, and by means of its own solvent action and the substances it contains in solution it effects, in the course of time, great changes in the rocks through which it passes. At great depths, where the temperature is higher than at the surface, water exerts a greater influence and causes changes of a more extensive character. Other hot liquids and gases are no doubt present at these greater depths, and changes in chemical composition and physical character must be caused by their action. We must take into account the influence of great pressure, both that which is due to the mere weight of overlying rocks and which is called static pressure, and that which is due to great lateral movements in the earth's crust and which is called dynamic pressure. It is not suggested that these various 
forces and agents act separately or independently, or even that they can be separated from each other logically. Sometimes one or other is of greater importance, but usually their actions are interdependent.

Great changes are thus produced in all rocks, the amount of change depending on the time during which the rocks have been acted upon, and on the intensity and character of the agents and forces concerned. There are some rocks which have been changed so completely that their original characters are practically destroyed, and it is by no means easy in many cases to determine the original nature of the rock. Such completely changed rocks were called metamorphic ${ }^{1}$ by the great geological teacher Lyell, and in his day (his teaching extended from about I830 to I875, and he first used the term metamorphic in his "Principles of Geology" in I859) very little was really known of the origin of the rocks of this great class. Thanks to modern studies, however, we now know that they were originally igneous or aqueous rocks, which have been so changed in character as to deserve a new name. It is to this great class of re-formed or re-moulded rocks that the name metamorphic is applied now.

Such rocks are of widespread occurrence, and as they give rise to distinctive types of scenery, and are often found to contain considerable quantities of metallic ores and other " minerals," they are of great importance to the geographer. The chief kinds are those named Gneiss 2 and the Crystalline Schists. ${ }^{3}$ Most gneisses are almost certainly altered plutonic rocks; many crystalline schists are just as certainly altered aqueous rocks. A

${ }^{1}$ Greek: meta, beyond or change from; morpha, form or character.

2 Gneiss, a German word of unknown origin.

3 Greek : schistos, divided. 
typical gneiss consists of irregular folia of a number of minerals, such as quartz, felspar, and mica; such a gneiss is probably a plutonic rock of the granite sub-class completely altered. A schist usually consists of finer folia of quartz and a mineral such as mica. Metamorphic rocks cover very large areas of the earth's surface.

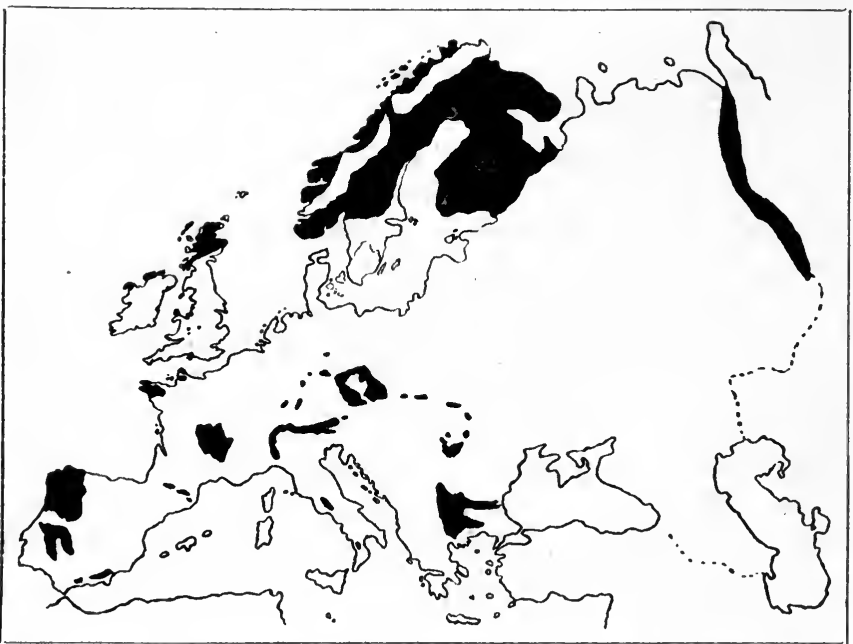

Fig. 2.-Map of Metamorphic Areas in Europe.

The map (Fig. 2) shows the European regions where such rocks are predominant.

There are thus three great classes of rocks :

Aqueous and Sedimentary Rocks.

Igneous Rocks.

Metamorphic Rocks.

The surface of the earth consists of these in very different proportions in different regions. Sometimes one class occupies a very wide area, as, for example, the metamorphic rocks of Finland and Northern Scandinavia. 
On the other hand, the British Isles contain representatives of all the classes and almost all the sub-classes, though, as we shall - see later, certain well-defined geographical districts in the British Isles are occupied almost solely by one kind of rock.

The geographer must constantly ask what are the rocks which occur in a region, because the scenery, the fertility of the soil, and the occupations of the people are so largely dependent upon the rocks. As already indicated, granites, for example, are hard, and usually give rise to infertile moorland or mountain conditions. Recent volcanic rocks, especially of the more basic types, weather into very good soil and give rise to some of the most fertile regions on the face of the earth. Much of the wonderfully fertile soil of Japan is derived from volcanic ash, as also is the highly productive soil in the neighbourhood of Naples. Metamorphic rocks are generally hard, and are associated with rugged scenery and infertile soil. Aqueous rocks are usually associated with gentler and softer scenery and with more fertile soil, though there is a considerable difference between the conditions produced by the various types. In the chapters dealing with land forms, and in the section dealing with economic geography, further reference will be made to some of the characters and properties of the different classes of rooks.

\section{The Relative Age of Rocks}

There is another point of view from which rocks must be considered by the geographer, and that is their relative age. The actual age of even the youngest rocks is practically unknown, certain exceptions being, of course, some volcanic rocks and aqueous rocks formed within historic times. We can make more or 
less plausible estimates of the age of some of the stratified' aqueous rocks, and of the time required for their formation, but at the best they are only estimates, and may possibly be very wide of the mark. We can, however, distinguish older from younger rocks, and so make a relative chronology of their formation.

In the case of some of the igneous rocks, more especially the plutonic sub-class, age is not of very much importance to the geographer, as plutonic rocks of very different ages, but of the same general composition, produce, on the whole, the same general types of scenery. Thus the granites of the central Highlands of Scotland, of Dartmoor, of the Wicklow Hills and of the Mourne Mountains give rise to very similar geographical conditions, though they are probably of different ages.

It is, however, somewhat different with the aqueous rocks. Here age is of very great importance, and the student of geography must be acquainted with the elementary principles and the terms used. The stratigraphical geologist determines their relative ages by using two well-understood principles. The first is that of superposition: it is obvious that, in the case of normal aqueous rocks occupying their original positions, newer rocks must overlie older ones; that follows from the method of formation. This point may be briefly illustrated. The Chalk of the English North Downs and the Chiltern Hills rests on a variable deposit of sand, and this in turn on a clay. The clay, called the Gault, is obviously the oldest or earliest formed of these three formations, and the Chalk is the newest. The sequence is as follows :

Chalk.

Sand ("Greensand ").

Clay ("Gault").

In the Pennine moorlands and on their flanks are the 
beds containing our coal-seams ; the series is called the Coal Measures. These rest on a thick series of coarse sandstones or grits; and these in their turn overlie a thick series of beds which are mostly calcareous. The coal measures are the newest of these three formations ; the limestones (the calcareous series) are the oldest. Tabulating as before, the sequence is :

Coal Measures.

Grits (" Millstone Grit.").

Limestone Series ("Carboniferous Limestone ").

The second principle used is not so obvious, but its enunciation came as the result of patient research combined with brilliant insight, just as with so many other important scientific generalisations. William Smith, an English engineer, a little more than a century ago, not only clearly stated and emphasised the principle of superposition briefly outlined above, but he was the first to lay down the principle that rocks of the same age contain, broadly speaking, the same kinds of fossils, and succeed each other in the same general order. It is thus possible to compare rocks in different regions. For example, there are rocks in North America which contain the same general fossils as those found in the limestones of the Pennines, and we have no hesitation in saying that the two sets of rocks are of the same age approximately. The well-known shellbeds of East Anglia contain the same fossils, in general, as certain beds in the plains of Western France; we unhesitatingly say that these East Anglian and French formations are of about the same age. The fossils in these latter beds are absolutely different from those found in the Pennine rocks. Hence these deposits are not of the same age as the East Anglian beds.

Relying on these principles, the geologist has been able to arrange a table of aqueous rocks according to 
their relative ages, using descriptive names derived in some cases from a region where the particular rocks either were first studied, or are very well developed, or from some fairly obvious feature of the rocks themselves. The student of geography continually uses the geologist's time-series of rocks. It is therefore given here for reference :

Table of the Systems of Sedimentary Rocks with SOME BRITISH AND OTHER EXAMPLES.

\begin{tabular}{|c|c|c|c|}
\hline Group. & System. & Examples. & $\begin{array}{l}\text { Prominent } \\
\text { Life-forms. }\end{array}$ \\
\hline $\begin{array}{c}\text { CaInozoic } \\
\text { OR } \\
\text { Tertiary. }\end{array}$ & 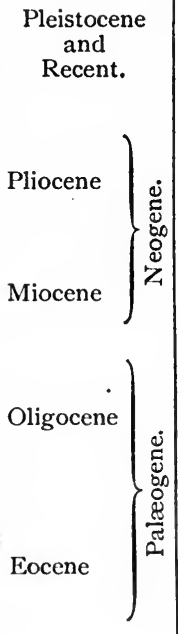 & $\begin{array}{l}\text { Alluvial deposits of the Fen- } \\
\text { lands. River gravels. } \\
\text { Old sea beaches. Glacial } \\
\text { deposits. Peat beds. } \\
\text { Gravels, sands, etc., of } \\
\text { East Anglia. Thick } \\
\text { marine beds of the Apen- } \\
\text { nines. } \\
\text { No undoubted British ex- } \\
\text { amples. Swiss conglome- } \\
\text { rates of Rigi, etc. } \\
\text { Sands, clays, etc., of Hamp- } \\
\text { shire Basin. Upper beds } \\
\text { of Paris Basin. Lower } \\
\text { Fresh-water Molasse of } \\
\text { Switzerland. } \\
\text { Sands, gravels, clays, etc., } \\
\text { of London Basin. Lower } \\
\text { beds of Paris Basin. } \\
\text { Numulitic limestone of } \\
\text { the Alps. }\end{array}$ & $\begin{array}{l}\text { Manmals be- } \\
\text { come very } \\
\text { c o } m \mathrm{~m} \text { o n, } \\
\text { and varied in } \\
\text { type. }\end{array}$ \\
\hline $\begin{array}{c}\text { MESOZOIC } \\
\text { OR } \\
\text { SECONDARY. }\end{array}$ & Cretaceous. & $\begin{array}{l}\text { Chalk of Downs, Chilterns, } \\
\text { Flamborough, etc. } \\
\text { Greensand, Gault clay, } \\
\text { Wealden beds. Quader } \\
\text { Sandstone of Saxony. } \\
\text { Lower Flysch sandstones } \\
\text { of Vienna Basin. }\end{array}$ & Birds appear. \\
\hline
\end{tabular}




\begin{tabular}{|c|c|c|c|}
\hline Group. & System. & Examples. & $\begin{array}{l}\text { Prominent } \\
\text { Life-forms. }\end{array}$ \\
\hline \multirow[t]{2}{*}{\begin{tabular}{|c|} 
MESOZOIC \\
OR \\
SEconDARY. \\
(contiuued)
\end{tabular}} & $x^{2}$ & $\begin{array}{l}\text { Limestones of Portland; } \\
\text { Bath, etc. Sandstones } \\
\text { of North Yorkshire. Ox- } \\
\text { ford clay. Shales and } \\
\text { limestones of Whitbyand } \\
\text { of Lyne Regis. Lime- } \\
\text { stones, etc., of Jura, } \\
\text { Plateau de Langres. } \\
\text { Ironstones of Cleveland, } \\
\text { Lincolnshire, Northamp- } \\
\text { tonshire, Wiltshire, Pla- } \\
\text { teau de Langres, Lor- } \\
\text { raine. }\end{array}$ & $\begin{array}{l}\text { Reptilean life } \\
\text { very varied } \\
\text { and in great } \\
\text { profusion. }\end{array}$ \\
\hline & $\begin{array}{l}\text { Trias or } \\
\text { Triassic. }\end{array}$ & $\begin{array}{l}\text { New Red Sandstone of } \\
\text { Cheshire and the Mid- } \\
\text { lands. Salt deposits of } \\
\text { Cheshire. Limestones } \\
\text { of the Tyrol. }\end{array}$ & $\begin{array}{l}\text { Mammals first } \\
\text { appear. }\end{array}$ \\
\hline \multirow[t]{3}{*}{$\begin{array}{c}\text { PAL.FozOIC } \\
\text { (Upper). }\end{array}$} & Permian. & $\begin{array}{l}\text { Red Sandstones of North } \\
\text { Nottinghanshire. Dolo- } \\
\text { mitic limestone of Dur- } \\
\text { ham, Yorkshire, and } \\
\text { Nottinghamshire. Some } \\
\text { pebble-beds of Midlands. } \\
\text { Zechstein of Germany. } \\
\text { Sandstones, shales, and } \\
\text { limestones of Perm in } \\
\text { Russia. }\end{array}$ & $\begin{array}{l}\text { Reptiles ap- } \\
\text { pear. }\end{array}$ \\
\hline & Carboniferous. & $\begin{array}{l}\text { Sandstones, shales, and } \\
\text { coal-seams of the coal- } \\
\text { measures of Britain, } \\
\text { France, Belgium, etc. } \\
\text { Oilshales of Scotland. } \\
\text { Millstone Grit of the } \\
\text { Pennines. Pennant Grit } \\
\text { of South Wales. Lime- } \\
\text { stones of Pennines, North } \\
\text { Wales, Mendips, Central } \\
\text { Irish Plain. }\end{array}$ & $\begin{array}{l}\text { Amphibia ap- } \\
\text { pear. Plant } \\
\text { life varied } \\
\text { and profuse. }\end{array}$ \\
\hline & Devonian. & $\begin{array}{l}\text { Limestones, slates, etc., of } \\
\text { llfracombe,South Devon, } \\
\text { Cornwall. Old Red Sand- } \\
\text { stone beds of Cheviots, } \\
\text { Central and North-East } \\
\text { Scotland. Limestones of } \\
\text { Eifel and Middle Rhine. }\end{array}$ & $\begin{array}{l}\text { Fishes very } \\
\text { common. }\end{array}$ \\
\hline
\end{tabular}




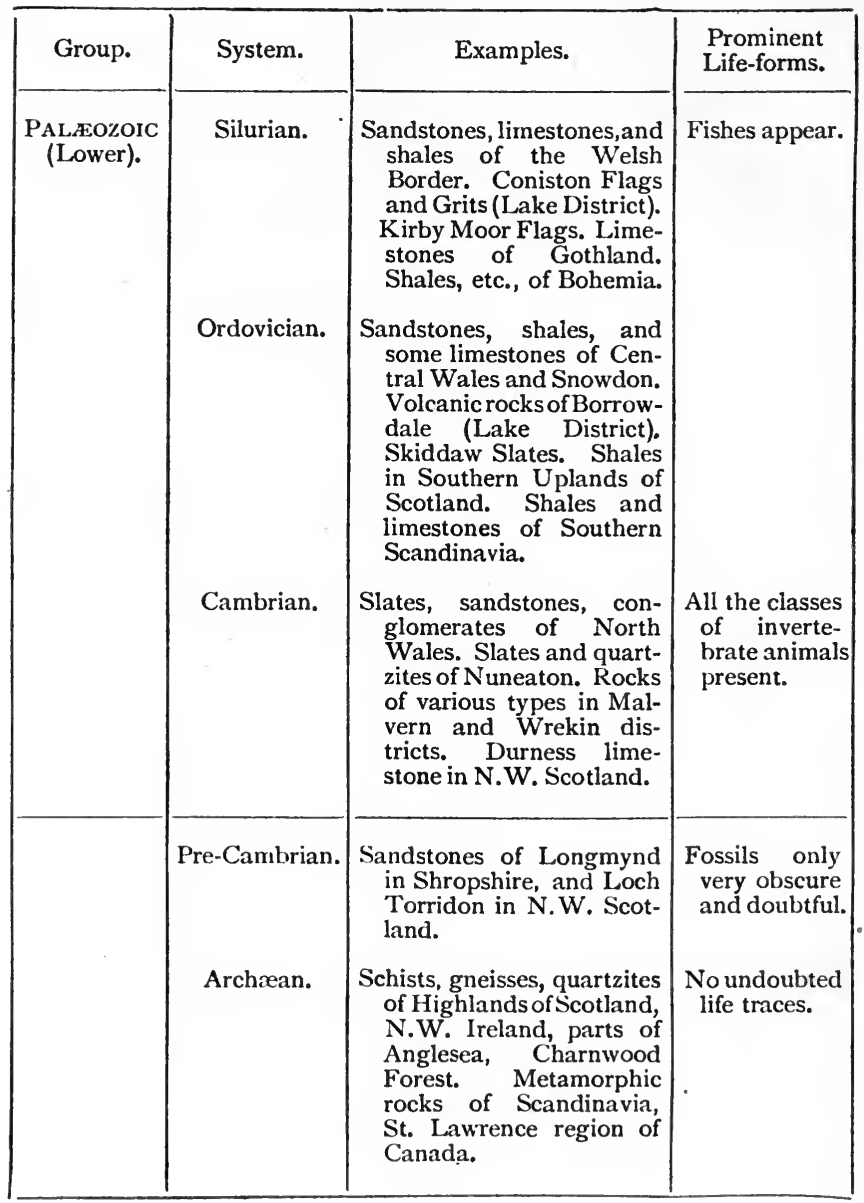




\section{BIBLIOGRAPHY.}

Elementary Geology-

(I) An Introduction to Geology. C. I. Gardiner. G. Bell \& Sons.

(2) A First Book of Geology. A. Wilmore. Macmillan \& Co.

(3) Geology for Beginners. W. W. Watrs. Macmillan $\&$ Co.

(4) Rocks and their Origins. G. A. J. Cole. Cambridge University Press.

More Advanced Text-Books of Geology-

(5) $A$ Text-Book of Geology. LAKE \& Rastall. E. Arnold.

(6) The Student's Lyell. J. W. JudD. John Murray.

(7) A Text-Book of Geology. Sir A. GeIkiE. Mar,millan \& Co.

Books on Special Branches of the Subject-

(8) The Building of the British Isles. JukES-Browne. E. Stanford.

(9) Stratigraphical Geology. Jukes-Browne. E. Stanford.

(10) Stratigraphical Geology. J. E. MARR. Cambridge University Press.

(I I) Text-Book of Petrology. F. H. HATch. Sonnenschein.

(12) Petrology for Students. A. Harker. Cambridge University Press.

(13) Volcanoes. J. W. JUDD. International Scientific Series : Kegan Paul, Trench \& Co.

(14) Volcanoes. T. G. Bonney. John Murray. 


\section{CHAPTER I I}

\section{LAND-FORMS}

THE rocks of which the earth's crust is composed seldom remain in the unaltered condition or in their original position. The strata of the sedimentary rocks are rarely horizontal, most of them having been bent, folded, and fractured. These changes in position and relationship are intimately associated with the various types of land-relief existing on the earth's surface. Land-forms are almost infinite in their variety, and grade into each other so imperceptibly that there is much difficulty in classifying them, and there is, as yet, no really satisfactory classification. We shall attempt an arrangement of convenience, from a geographical point of view, in this and the succeeding chapters.

\section{Movements of the EARTh's Crust}

It is necessary to realise, at the outset, that the earth's crust is in an unstable condition; even those regions which seem to be the most stable being subject to frequent, though minute, disturbances. The region of the British Isles is popularly regarded as typically stable, but modern refined methods of observation show that it is disturbed by very frequent small earthtremors. Many parts of the British Isles are subject to slight earthquakes. These seem to be most frequent near the great boundary fault, or line of dislocation, which separates the Grampian Highlands from the 
Midland Valley of Scotland. It has been shown that earth-shocks of very slight intensity may occur there at the rate of two or three per day.

In many parts of the world earthquakes of greater intensity are of frequent occurrence, and their effects are too obvious and notorious to need emphasis here. It may, however, be pointed out that the geographical effects of even the greatest earthquakes are usually very slight. They produce a great impression upon the human mind, and are very destructive of man's work, but they usually change the surface of the earth but little. Occasionally greater effects are produced, as in the famous example studied by Charles Darwin in Chile in I835, where he showed that the coast of that unstable region had been relatively raised to the extent of 8 or Io feet. In the destructive earthquake of San Francisco in I906 there was some vertical and horizontal displacement of the ground along a line of fault. In the Alaskan earthquake of I899 the beach was raised in places by over 40 feet, and barnacles could be seen, several years after the shock, still attached to the rocks far above high-water mark. Again, in the earthquake of South Calabria in December Igo8 there was measurable displacement of the surface. To anticipate somewhat, it may be remarked that the area affected by the last-mentioned earthquake lies on the inner or concave side of a great curve of "fold-mountains." The earth's crust inside this curve is, in all probability, still sinking, and the Tyrrhenian deep sea is a recently foundered part. The rim of this sinking part is, therefore, subject to frequent earthquakes. This is frequently the case on the inner or concave side of such fold-mountain curves.

There are movements going on in the earth's crust which are not so obvious as those connected with the 
greater earthquakes, but which are much wider in scope, and affect larger areas. These slow movements have long been studied in Sweden where the pioneer naturalists, Celsius and Linnæus, made their now classic observations. To the north of Stockholm the land is rising at the rate of at least 2 or 3 feet per century; in Scania (Southern Sweden) the land is sinking probably at rather more variable rates. In the north of Norway the land must have risen at least some hundreds of feet in Pleistocene and recent times. Similar evidence has now been accumulated from many parts of the world, and there is not the least doubt that great areas of the crust are sinking, and in other regions great areas are relatively rising. The cause of these great crustal movements is not quite clear; it has been held that it is connected with a secular cooling of the earth, but there is now considerable doubt whether that will furnish a satisfactory explanation. The facts are clear; the full explanation is a matter for future research, and its further discussion outside the scope of this book.

Two broad, general types of crustal movements are now recognised, namely, those which act in a radial direction, and those which act in a tangential direction. The former cause elevation or depression of large areas; that is, movements away from or towards the centre of the earth. These movements have been termed continent-building, but the term is open to considerable objection. The latter act in a direction more or less parallel to the earth's surface, and are often known as mountain-building movements. The two types of movement are not independent of each other; on the contrary, they usually seem to have been closely associated. They produce, respectively, some of the most important and well-defined of the land-forms. 
Folded or Alpine Mountains.-The most conspicuous features in the structure of most of the continents are long lines of mountains composed of intensely folded strata, and carved by the forces of erosion into the sierra-like forms so familiar in the Alps and other mountain ranges of Southern Europe. As the Alps have been studied with great thoroughness by both geologists and geographers, and as their structure seems to be quite typical, the descriptive name, "Alpine mountains," is often applied to such mountain chains everywhere.

Such mountain ranges are mainly the result of forces acting in a tangential direction; and the first apparent result of such forces is the production of folds in the strata. Earth-folds may be illustrated in a very effective and simple manner by placing weights on a thick, heavy tablecloth and then pushing the latter across the surface of the table. According to the nature of the cloth, the intensity of the thrusting force, and the resistance offered, the folds will vary from quite simple ones to those of a complex character.

The simplest folds in the rocks are those in which the strata are bent fairly equally into the form of an arch or trough, known in geology as the anticline and syncline. The south-eastern quadrant of England furnishes excellent illustrations of these simpler folds. Let an observer travel from Aylesbury to London and then from London to Brighton, and let him observe the nature and position of the rocks. $\mathrm{He}$ will, in the course of his journey, meet with three lines of low chalk hills. The first are the Chiltern Hills ; these are chalk downs presenting a relatively sharp face to the northwest and a gentler slope towards London. The latter is the " dip-slope," and the strata dip or slope at a low angle towards the Thames Basin. At Watford or 
Rickmansworth the chalk surface is left behind and the Tertiary strata of the London or Thames Basin begin. From this point to near Croydon the Tertiary rocks continue at the surface, though the chalk has been proved to occur below them in numerous borings

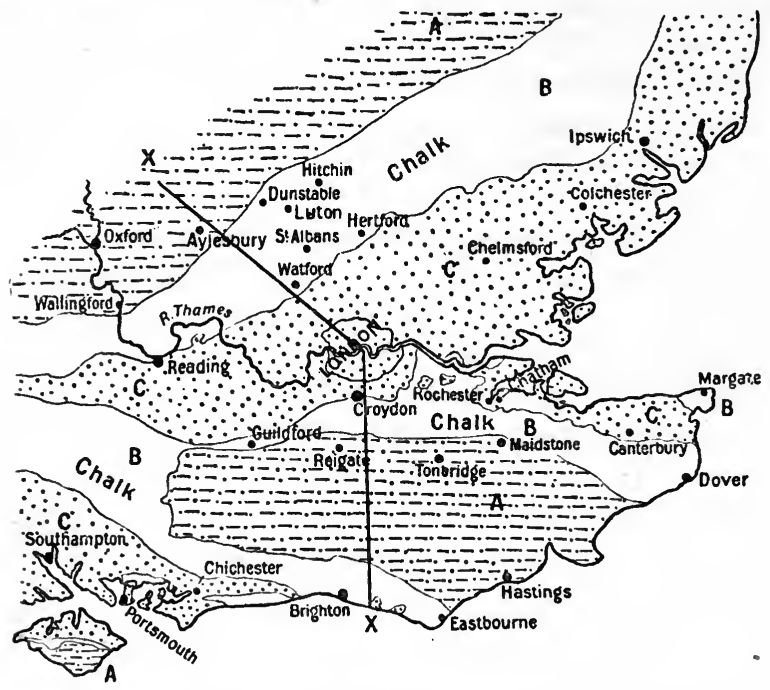

Fig. 3.-A Geological Map of the South-Eastern QUADRANT OF ENGLAND.

A. Rocks older than the Chalk. B. Chalk of Chilterns, North Downs, etc. C. Tertiary strata, newer than the Chalk. $\mathbf{X}$-X Line of section shown in Fig. 4 .

for water. The chalk reappears at the surface in the North Downs, these hills, however, having the dipslope towards the north and the sharper cut edge (called the escarpment face) towards the south. At Reigate or Red Hill strata older than the chalk are seen, and these continue across the Weald until the chalk reappears in the South Downs. In these hills the sharp 
edge faces the north and the gentler dip-slope is toward the English Channel. The observer has thus passed over a downfold or syncline, and an arch or anticline, the summit of which has been removed by long-continued denudation. The Chilterns, the London Basin, the North Downs, the Weald, and the South Downs thus form parts of a great earth-wave consisting of an anticline and a syncline. This wave represents a distant part of the great "Alpine Storm" of Europe. The relations of these rocks of South-Eastern England are shown

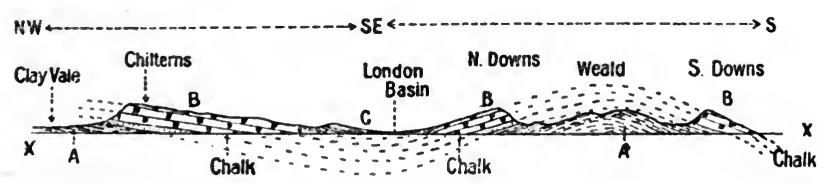

Fis. 4.-A Section from near Aylesbury to London, AND TO BRIGHTON.

A. Rocks older than the Chalk. B. Chalk of Chilterns, North Downs, etc. C. Tertiary strata, newer than the Chalk. (See Map, Fig. 3.)

in the geological map and diagrammatic section (Figs. 3 and 4), which should be carefully studied.

Some regions show much more complex folding than that of the Thames Basin and the Weald. The Jura Mountains on the Franco-Swiss border consist of Mesozoic rocks thrown into a sharp succession of anticlines and synclines, with much faulting or dislocation of the strata. The same "Alpine Storm" which produced the folding of South-Eastern England displayed greater intensity in the Jura region, and produced the more complicated folding.

Very much more complex, however, are the earth storm effects in the Alps, where there is much compli- 
cated overfolding and often displacement of strata by huge thrusts. Here the tangential pressure-forces have acted from one side more than from the other, hence the folding produced is of a pronounced asymmetric character. Not only have great folds been produced, but they have been flattened out afterwards, and portions have often been detached, and older rocks have been pushed over newer ones.

The Alps consist for the most part of rocks of later Palæozoic, Mesozoic, and early Cainozoic Age. The great tangential folding movements combined with some vertical uplift took place in Middle Cainozoic times chiefly, and were so intense that the shortening of the arc of the earth's crust has been estimated at from 70 to Ioo miles.

Evidence of this complex folding of the strata may be readily seen in many parts of the Alps. Standing on the northern slopes of the Dent du Midi and looking across the Rhone Valley to the mighty walls of the Dent de Morcles and the Diablerets beyond, the observer may see immense folds involving thousands of feet of strata. The mountain walls have been trenched by vast rock-falls, and on the gigantic, precipitous rock-faces the great bends of the Mesozoic rocks may be seen miles away (see Fig. 5). At Martigny, in the Gorge of the Lizerne, and in the Trient Valley, similar evidences of stupendous folding may be seen.

A most interesting district for the study of Alpine folding is the neighbourhood of Lake Lucerne. In Fig. 6 a study of a well-known section is given, in which the complex folding of the Mesozoic and Cainozoic rocks, forming the Bürgenstock and the Musen Alp, are seen to have reached the stage of complete inversion. The older Trias and Jura are folded over on top of the 
newer Cretaceous and Eocene, and to the left of the section the whole vast system of folded rocks is thrust

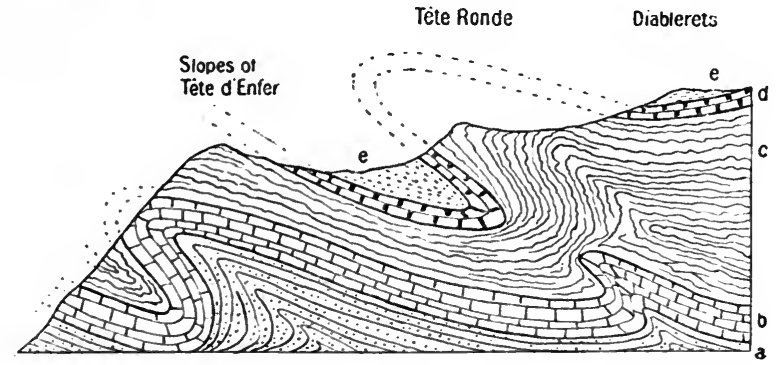

Fig. 5.-Diagrammatic Section throvgh the Rocks on the Southern Face of THE Diablerets, Western END OF THE Bernese Oberland, and overlooking the Rhone Valley.

a. Upper Triassic Rocks. b. Lower Jurassic Rocks. c. Lower Cretaceous Rocks. d. Upper Cretaceous Rocks. e. Eocene Rocks. The Eocene Rocks are folded in, between the older Lower Cretaceous Rocks.

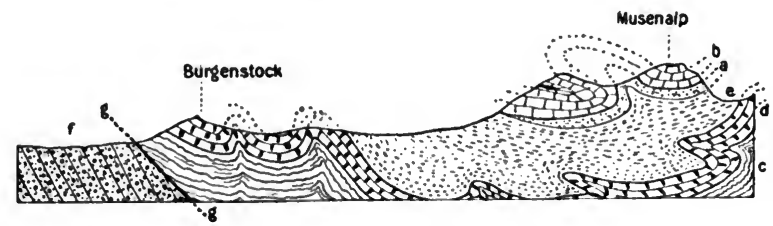

Fig. 6. -A Diagrammatic Section through the Rocks of THE BÜrgenstock and MUSEN Aly, NEAR LAKe LUCERNe.

$a$. Triassic Rocks. b. Jurassic Rocks. c. Lower Cretaceous Rocks. d. Upper Cretaceous Rocks. e. Eocene Rocks. $f$. Miocene Conglomerate (Nagelfluh). The older rocks, $a, b$, have been folded over above the newer Eocene, $e$. The whole of the Mesozoic and Lower Tertiary rocks have been thrust over the newest rocks of the section, the Miocene. A "thrust-plane" is shown at $g \ldots g$.

against and partly over the more recent Miocene conglomerate.

Uplift and folding constitute one phase in Alpine 
history, erosion and denudation a second phase. Erosion proceeds with great rapidity in these high mountains. One only needs to see the state of Alpine torrents after a rainstorm on the mountains, or to notice the evidence of rock-falls, which occur so frequently, to realise how rapid is the process of erosion, and how quickly the great masses of folded rocks are being carved into ranges of contrasted peaks and deep valleys, and the whole system reduced to a lower level.

The rapid erosion gives the sierra character, with the series of sharp peaks so characteristic of Alpine ranges. The descriptive Spanish word, "sierra" 1 is, therefore, frequently used to describe the profile of Alpine ranges, of which the Sierra Nevada range in Southern Spain is another good example. There is a succession of names in the Alps which bears eloquent testimony to their sierra character. In the Mont Blanc region are the famous Aiguilles (Fr. aiguille, needle); examples:Aiguille Rouge, Aiguille Verte, Aiguille du Dru. Among the mountains adjoining the Rhone Valley the name dent (Fr. dent, tooth) is of frequent occurrence; examples:-Dent du Midi, Dent de Morcles, Dent Blanche. In the Pennine Alps and the Bernese Oberland are the famous horns (Teutonic, horn), such as the Matterhorn, Wetterhorn, Weisshorn, Schreckhorn, and a score of others. In Canton Glarus, piz (akin to the northern spitz, pointed peak) occurs over and over again ; examples :-Piz Linard, Piz Bernina, etc.

Alpine ranges are notched by valleys of greater or lesser depth, which provide access to the middle of the chains. It often happens that two river-valleys from opposite sides have cut back so far that a low notch results, and a pass is formed. From end to end of the Alps passes occur which are famous as the routes ${ }^{1}$ Sierra: Spanish, saw-like, from Latin, serra, a saw. 


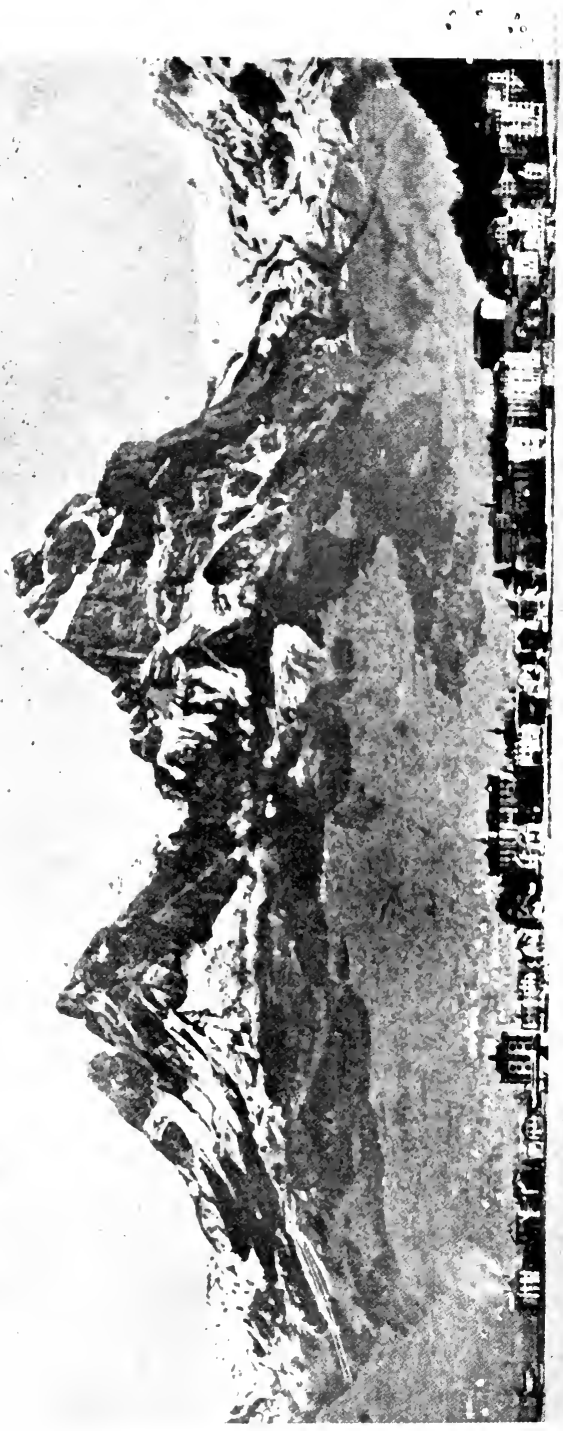

(4)

(1)

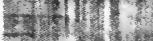

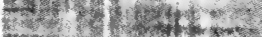
Ma of
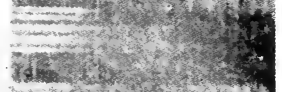

ברב

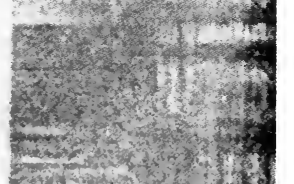

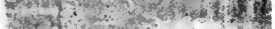

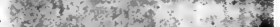
(2)

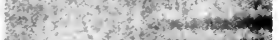

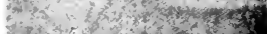
and $x$.

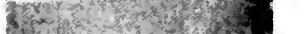

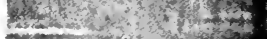

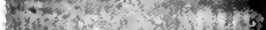
2. con $-1,1$.

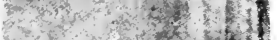
(5)

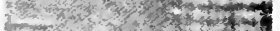

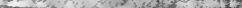

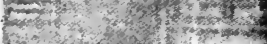

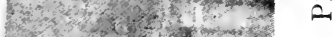

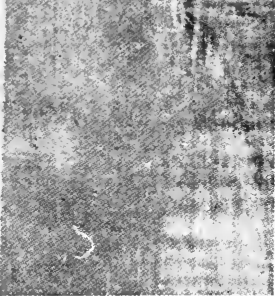




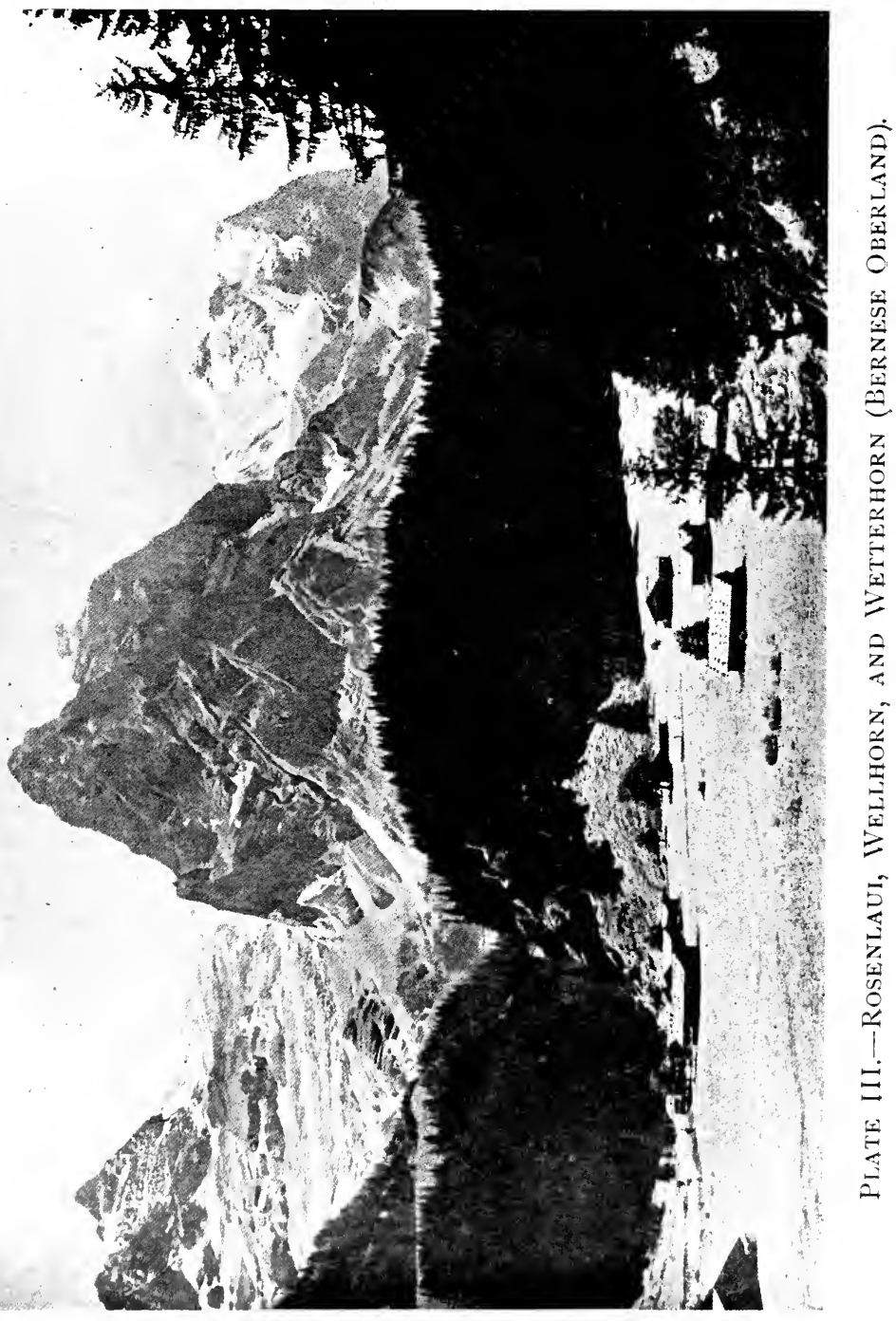


across which, in peace and in war, men have traversed the mighty ranges. The more famous passes sometimes determine the divisions of the Alps as used by the geographers; for example, the Pennine Alps are usually held to extend from the Great St. Bernard Pass to the Simplon Pass, and the Lepontine Alps from the Simplon Pass to the group of passes near the head of the Hinter Rhine. Similarly, in other great ranges of Alpine type, there are passes, higher or lower, as the case may be. Most of the passes in the high Alps are between 6000 feet and 8000 feet above sea-level; those in the lower Carpathian range are between $I_{500}$ feet and 3000 feet above sea-level; those of the mighty Himalaya are above 15,000 feet and at least one of over 20,000 feet above sea-level is in fairly regular use.

Young mountain ranges of the general Alpine type occur in all the continents; they are characterised by the same general features-rock-folding of a complex character, notching by erosion into sierra lines of sharp contrast, with means of communication across passes of varying height and difficulty. Each great system has its own individual characteristics, as may be expected. For example, in some ranges there are active volcanoes which introduce another element into the structure of the chain. No recently active volcanoes occur in the European Alpine system strictly so-called, but in the Caucasus and Elburz ranges, which link the lesser European system to the greater one of Asia, there are volcanoes which are dormant or which have become extinct in comparatively recent times.

The Eurasian system includes the following welldefined ranges :

Pyrenees, Alps, Carpathians, Balkans.

Sierra Nevada, Atlas (N. Africa), Apennines. 
Dinaric Alps, Pindus Mountains, Mountains of Crete, Taurus, and Anti-Taurus.

Mountains of Southern Crimea, Caucasus, Kopet Dagh, Mountains of Khorassan, Hindu Kush.

Pontic Mountains, Armenian Mountains, Elburz Mountains.

Kurdistan Mountains, Zagros Mountains.

Pamirs, Sulaiman Mountains, Karakorum, Himalaya, Kuen-Lun, Thian Shan.

The student should study this great system of foldmountains on a good orographical map.

In Eastern Asia, in the islands of Malaysia, and in New Zealand there are great loops or festoons of volcanic mountainous islands which are probably an immense Alpine system, large parts of which are below sea-level. The mountains of Kamchatka, of Japan, of Sumatra and Java are quite Alpine in character, though studded with numerous active volcanoes. The New Zealand Alps possess the typical features of an Alpine range, and the name is well-deserved. In North America a triple line of fold-mountains extends from Alaska in the north-west to the Mexican plateau. The Rocky Mountains form the eastern rampart of the great elevated region of Western North America. On the Pacific side of this western system of highlands are the coast-ranges overlooking the deep ocean, and an inner system of which the Sierra Nevada and Cascade ranges are the best known. In Mexico, Central America, and the West Indies, is a system somewhat comparable in form to that of Eastern Asia. The general trend of the mountain-lines is here east and west, with concentric curves or festoons of volcanic mountains and mountainous islands. The triple line of the Cordilleras of the Andes in South America corre- 


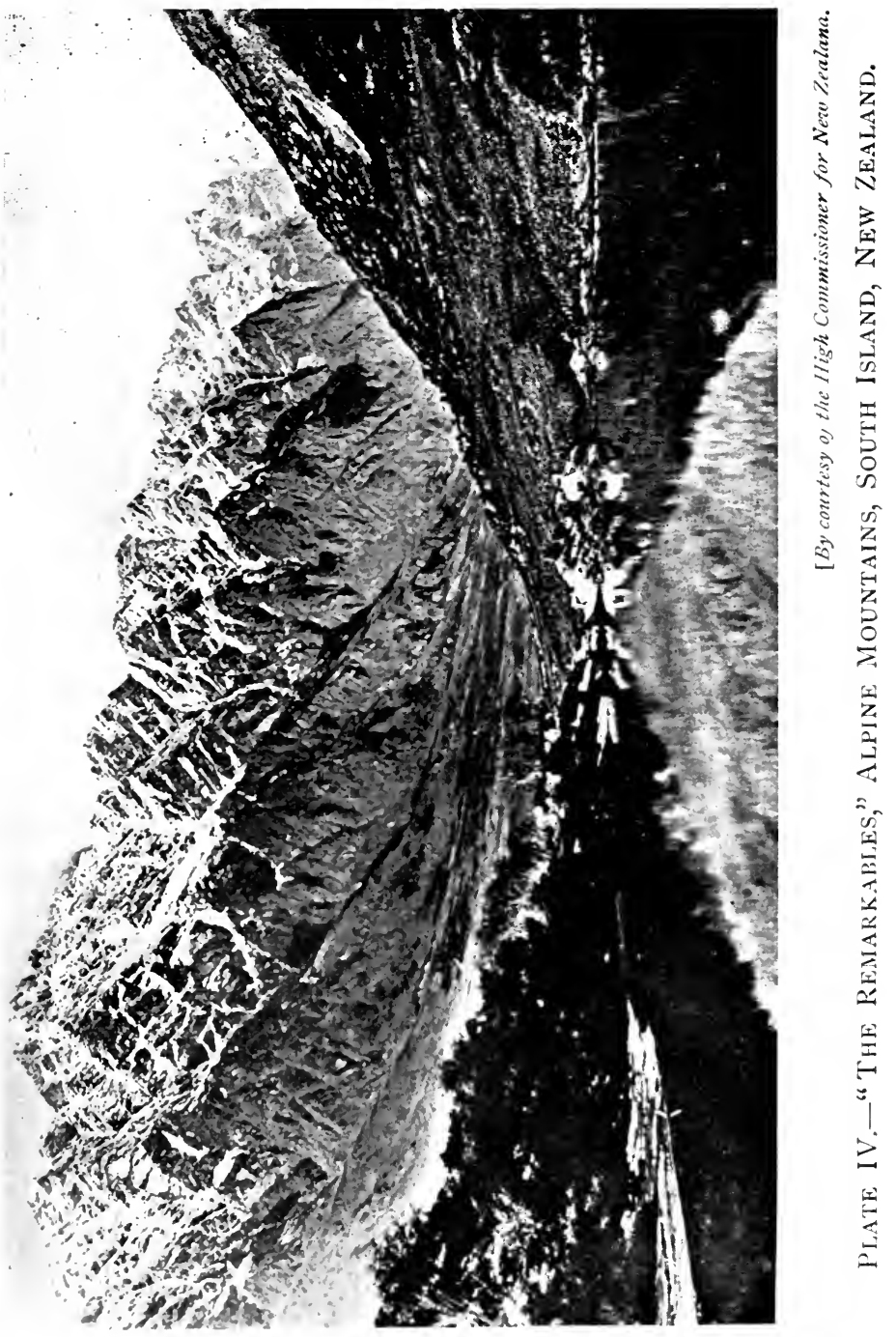




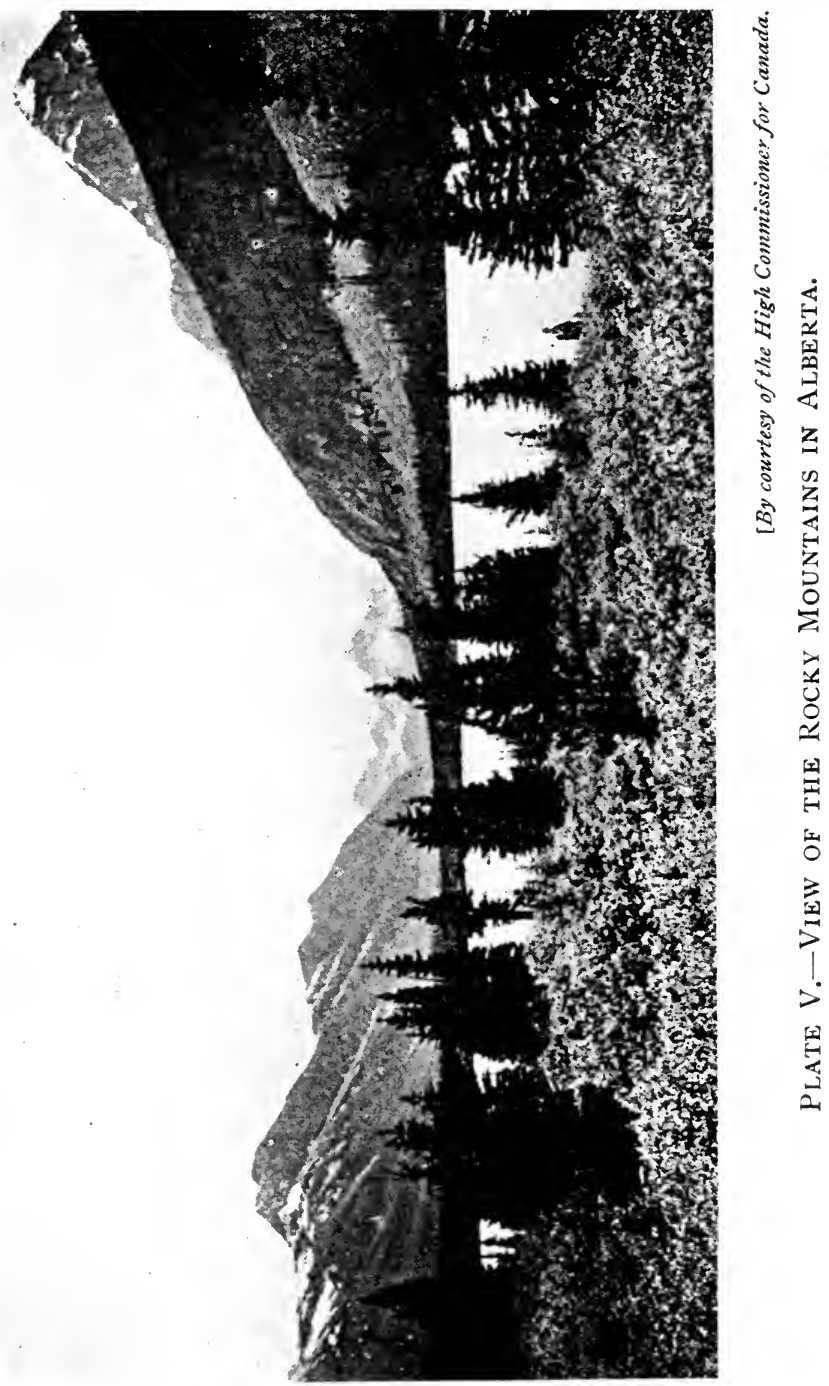


sponds generally with that of the North American ranges, but while the latter widen out to more than Iooo miles in their middle part, the South American system barely reaches half that width in its widest part.

Older Alpine Mountain Ranges.-It is clear from the consideration of Alpine mountains that they are prominent features in the structure of the continents. The ranges enumerated in the preceding section have acquired their present general form and structure in the later geological periods. Most of them date from Cainozoic times. It seems reasonable to suppose that similar folding, followed by an erosion phase, must have occurred in the older geological periods, and the wrecks of older folded mountains may reasonably be expected among the various land masses. As a matter of fact all the continents show traces of older continents, and the grain of old mountain ranges may often be seen partly obliterated by the more recent mountain-building movements. This subject may be illustrated by examples.

\section{Caledonian Range of North-West Europe}

In the Devonian period a vast continent stretched across what is now the North Atlantic and most of Northern Europe. Across this northern continent tangential pressures in the earth's crust produced an old Alpine range, just as pressure in the crust produced the present Alps in Tertiary times. This ancient range stretched at least from the west of Ireland to the northeast of Scandinavia, and was probably as extensive as the modern Himalaya. The long-continued erosion phase began towards the close of the Devonian period and was continued through the Carboniferous and later geological periods, The erosion of its plutonic and 
metamorphic rocks, and probably of its sediments, provided, during the Carboniferous period, the material for the formation of the immense deposits of the Millstone Grit of the north of England. Since that time the range has been subject to many geological " accidents," and now only its worn-down and broken relics are left as the Highlands of north-west Ireland, the Highlands of Scotland, and the plateau-highlands of Scandinavia.

Armorican and Variscan Mountain Fragments of Europe

Another ancient mountain system, or perhaps two distinct systems, dating from Permian times, long existed in the region of Central and Western Europe. This range or ranges was probably not so complex in structure as the Alpine Caledonian chain. Its denuded and broken fragments form the series of low mountains of middle and western Europe, including the Riesen, Erz, Fichtel, Thuringer, Harz, and Rhön mountains, the Westerwald, Taunus, Black Forest, and Vosges. These fragments have been named the Variscan mountains. The Hunsrück, Eifel, Ardennes, the Auvergne of Central France, the rocky highlands of the Cotentin, Brittany, Devon and Cornwall, and Southern Ireland, with possibly the Meseta of Spain-have been named the Armorican Mountains. These Armorican highlands may be a little older than the Variscan highlands. Both of them suffered erosion and denudation during the long Mesozoic and Cainozoic eras, and both took part in resisting and giving direction to the Alpine earth-storm. The denuded and broken fragments stand in the modern continent as reminders of a Europe long since passed away. These residual blocks of the Armorican and Variscan systems lead us naturally to a consideration of "Block Mountains."

Block Mountains, - These are portions of the earth's 
crust which have been uplifted bodily above the surrounding country, or which have been left standing when adjacent blocks have subsided. A classic instance, and one of the best possible illustrations, is furnished by the old blocks of the Vosges and Black Forest, with the depressed valley of the middle Rhine between them,the "Rift Valley" of the Rhine. The relation of these crust-blocks will be best understood from a brief history of the whole region. At the end of the Jurassic period the eroded, irregular surface of the old Variscan mountains had been depressed below sea-level and was covered with $\mathrm{a}_{\text {。 }}$ thick mantle of Mesozoic rocks. This stage is represented in the diagrammatic section, Fig. 7A. During the earlier Tertiary Alpine movements there was depression of the whole region, involving not only the Mesozoic strata but also the underlying granites, gneisses, and Palæozoic sediments. A middle-European sea flowed over a sunken part in the Oligocene period, on the floor of which were deposited the marine Oligocene strata now found under the covering of the Rift Valley. The section (Fig. $7 \mathrm{~B}$ ) represents the condition of things at the end of the phase.

The great folding-movements of the Alps took place, as already stated, in Miocene times, and the region under consideration was again subjected to disturbance. Two paraliel lines of faults were initiated, which let down the Rhine rift valley between the horsts ${ }^{1}$ of the

${ }^{1}$ A horst is a crust-block left standing during the subsidence of the adjoining region more or less on two sides. The following are well-known examples: The Grampian Highlands of Scotland bounded by the fault line of Glenmore and the Highland boundary fault; the Thuringer Wald; the small plateau of Morvan in Central France; the mass of Sinai with the sunken Red Sea on one side and the Gulf of Akaba on the other; and Korea, between the sunken areas of the Yellow Sea and Japan Sea. 
Vosges and Black Forest. Subsequent erosion removed most of the Mesozoic strata from the higher

A
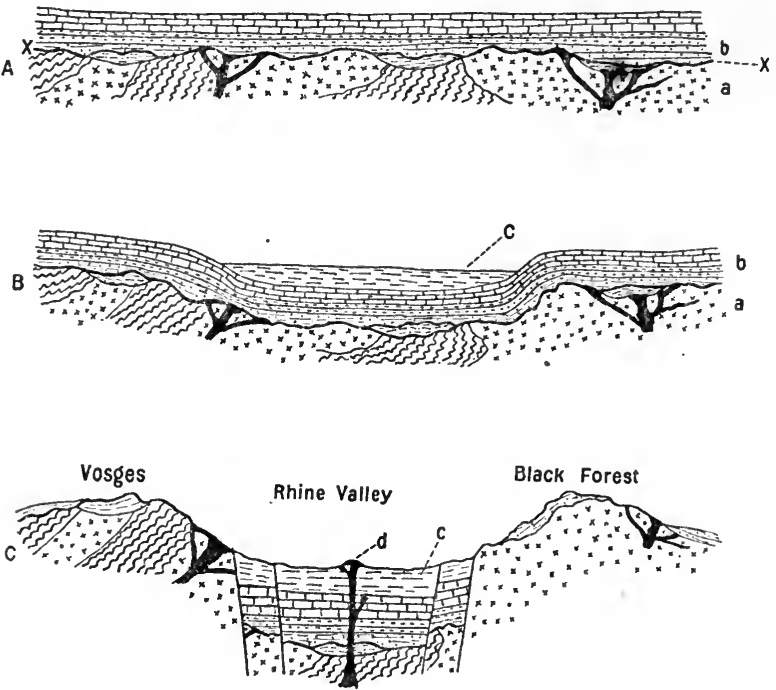

Fici. 7 A, B, C.-Diagrammatic Transverse Sections across The Rhine Rift-Valley and the Adjacent Crust-Blocks at different Geological Periods.

A. At the end of the Jurassic period. B. At the beginning of the Miocene period before the great "Alpine Storm" occurred. C. At the present time.

$a$. Palæozoic, and older Igneous, and Metamorphic rocks. b. Mesozoic rocks. $c$. Oligocene rocks. $d$. Later Igneous rocks forming the Kaiserstuhl. A pre-Mesozoic land-surface is shown at $\mathbf{X}$...... in Fig. 7 A.

parts of the region. This final stage is represented by the section, Fig. $7 \mathrm{C}$.

The Vosges and Black Forest thus stand up as Block Mountains with the rift-valley of the Rhine between them. The Feldberg of the Black Forest is 4900 ffeet high, 
the Belchen of the Vosges 4700 feet, the rift valley has an average elevation of about 600 feet. The Rhine flows through a plain of recent deposits, at Basle at a height of 870 feet; near Strassburg, of 470 feet; at Mannheim, of 300 feet.

The other parts of the Variscan and Armorican ranges were broken up in various ways. Deep and long fractures cut the ranges into blocks which rose or fell independently, and thus the old fragments stand up as the block mountains of middle and western Europe. Many of these are now worn into the condition of a plateau; especially is this the case with the Belgian Ardennes and the Eifel.

Plateaux.-From the consideration of block mountains we may now pass to the closely related areas of uplift, generally of greater extent and usually of more even surface, known as Plateaux. It has already been mentioned that movements of displacement of large portions of the earth's crust, from or towards the centre of the earth (radial movements), are interdependent with the tangential movements which produce folded mountains. At the time of the folding which produced the younger Eurasian mountains, for example, great areas of depression were formed on the inner or concave side of the mountain curves. Thus were produced the depression of the Hungarian Sea, afterwards to be filled with sediments and to become the Hungarian Plain; the Adriatic Sea, a part of which has already been filled with sediments to form the Plain of Lombarcly; and the Tyrrhenian Deep, enclosed between Italy, Sicily, and Sardinia. During the same long period uplift of great masses took place, chiefly earthblocks already in existence, some of which were unevenly tilted and frequently broken in the process. The Meseta of Spain, the Auvergne plateau, and the 
lozenge-shaped plateau of Bohemia, with its irregular surface, then took on their modern form.

In Asia, the plateaux whose positions and relations were then determined are on the stupendous scale. The fold-mountains of that great continent are intimately related to the areas of elevation and depression of large earth-blocks, just as in the case of Europe. The plateau of Anatolia or Asia Minor is bounded by the Pontic Mountains on the north and by the Taurus and Anti-Taurus Mountains in the south and southeast. The plateau of Iran is surrounded by Alpine ranges,-Kopet Dagh, Hindu Kush, Sulaiman Mountains, Zagros Mountains, Kurdistan Mountains, and Elburz Mountains. The greatest and highest plateau in the world,--that of Thibet,- -has round it the Pamirs, the Karakorum, the Himalaya and Trans-Himalaya, and the Kuen Lun and Thian Shan mountain ranges, whose length and height are commensurate with the mighty crust-block they surround. The Tarim basin is a plateau of lesser elevation among the enormous masses of mid-Asia. Situated almost in the middle of the continent, and almost surrounded by mighty walls of Alpine mountains, it is a relative depression with an average elevation of about three thousand feet above sea-level.

The Arabian plateau and the Deccan of India are not so obviously related to any lines of Alpine mountains. They are probably part of an ancient continent which included much of the present Africa and Australia, as well as the semi-detached parts of Southern Asia. This ancient continent seems to have been remarkably free from such lines of sharp folding as are characteristic of Eurasia and the Americas, hence its relics are plateaux which have been the theatre of long-continued denudation, and subject to many accidents of earth-movement 


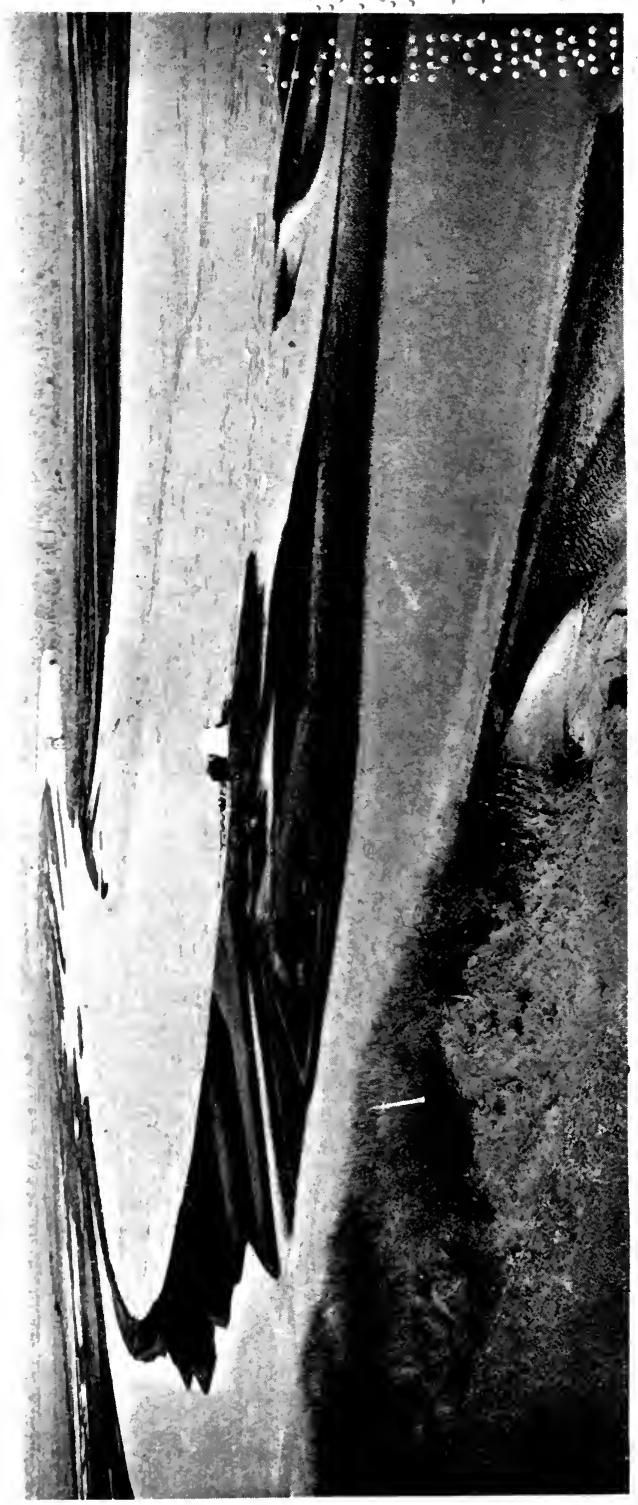

$\frac{\pi}{\Sigma}$

5

ลे

$\Rightarrow \frac{1}{2}$

¿

₹ $=$

¿

ป

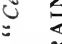

ล

ช

¿ूँ

$\Xi$

z

岕

2

宓

1) 
since Permian or Triassic times. The recognisable parts of this ancient continent are the plateaux-regions of Africa, Arabia, the Deccan, and Australia.

The great plateaux and basins of North America are closely related to the long lines of Alpine mountains in much the same way as those of Eurasia are to the similar mountains of the Old World. An orographical map of North America shows a succession of plateaux and elevated basins between the Rocky Mountains and the western coast-ranges. These plateaux are mainly large blocks of the earth's crust bounded by faults or by simple folds. The Mexican and Colorado plateaux, the Utah basin, the Columbia, Frazer, and Yukon plateaux are structural divisions which the student will readily understand.

In South America the western mountain-system is threefold as in North America, but its parallel ranges are too close together to allow of table-lands as large as those of the northern continent. In latitude $18^{\circ} \mathrm{S}$., Lake Titicaca occupies the same relative position with respect to the mountains of South America that the Great Salt Lake occupies in North America.

It may be mentioned here that there are immense plateaux of a different type in North America east of the Rocky Mountains. These vast plateaux slope gradually from heights of over 6000 feet to the comparatively low alluvial plains in the middle of the continent, and present monotonous stretches of prairie dissected by the great rivers which drain to Hudson Bay and the Gulf of Mexico. The "Bad Lands" of Dakota consist of plateaux-blocks deeply scored by the White River and its tributaries. The rivers have cut so deeply that some portions of the dissected regions are almost inaccessible. These plateaux are related, in all except their elevation, to the plains of alluvium and recent sedimentation to be 
discussed later, more than to the crust-blocks already described. They are mentioned here in order to emphasise again the difficulty of establishing hard-and-fast divisions of land-forms.

Mountain-rims of Plateaux.-Plateaux of the crustblock type have frequently elevated, scarped edges, which from neighbouring lowlands appear as considerable mountain-chains, but which present only a moderate elevation when seen from the surface of the plateaux. The following well-known examples may be quoted: the Cevennes 'range' is the eastern rim of the tilted Auvergne crust-block, the Sierra Morena is the southern edge of the Meseta of Spain, the Erz Gebirge and Riesen Gebirge form the northern edge of the Bohemian crustblock plateau, and the Western Ghats form the sharp mountainous western edge of the Deccan of India.

Fractured Crust-blocks.-The fracturing of the Variscan and Armorican mountain-systems prepares us for the frequent fracturing of the residual fragments. Such fracture-lines are of frequent occurrence, and are geological accidents which have produced important geographical consequences. The lozenge-shaped plateau-massif of Bohemia has been extensively fractured; and from the cracks there have been extrucled sheets of lava, and showers of volcanic ash ejected. The famous hot springs of Carlsbad, and other well-known hot springs in Bohemia, are relics of these disturbances and of the volcanic phase existing in Tertiary times. Occasional earthquakes show that the region is yet somewhat unstable. Similar fractures in the central plateau of France allowed of the formation of Tertiary volcanoes. The Puys of Auvergne are obviously very recent structures, whose activity seems to have continued almost or quite to the human period. Numerous hot springs again remind us that there is 
heated material probably at no great depth, and that the fracture-lines offer facilities for the heated waters to reach the surface. The hot springs of the Vosges, Black Forest, Taunus, Hunsrück, Eifel, and Ardennes are probably of similar origin. Many crust-blocks, in different parts of the world, have been subjected to similar geological accidents, to which much of their variety of surface is due.

Plateaux of Denudation.-Some plateaux are due to long-continued denudation acting on old block-mountains or on very old Alpine mountains. The "felds" of Scandinavia are irregular plateaux produced by the denudation of the old Caledonian Range already described. Farther east, in Finland, denudation has reduced the system to the condition of a comparative lowland, over which are scattered innumerable lakes. In the Highlands of Scotland the same old mountainsystem has been worn down to the condition of a plateau, dissected by the deep, irregular glens so characteristic of such a highland region. The British part of the Caledonian mountain-system is thus intermediate in character and in elevation between the Kiolen and Dovrefeld of Scandinavia and the Archæan lowland of Finland. This is another illustration of the difficulty of obtaining a rigid classification of land-forms.

The Laurentian Highlands, north of the St. Lawrence, and the greater part of Labrador, consist of very ancient rocks which have been worn down approximately to the condition of a peneplane. ${ }^{1}$

Plateaux in Dry Regions. - In regions of very low rainfall plateaux remain, on the whole, fairly level, because hollows produced either by earth-movements or by previous denudation are rapidly filled with wind-borne material. The rare rains which occur are usually tor- 
rential, and loose material from the exposed rock-surfaces is swept into the hollows. The vast plateaux of such dry regions have, therefore, undulating surfaces quite unlike the dissected plateaux of regions of moderate or heavy regular rainfall. The Arabian plateau and the Western Highlands of Scotland may be contrasted as extreme types in this respect.

Many block-mountains, crust-block plateaux, and plateaux of denudation have not been mentioned. The aim has been to show, by means of well-known examples, the nature and origin of some of the land-forms, and especially to emphasise the close relationship between the various types mentioned.

\section{BIBLIOGRAPHY}

(I) Geography: Structural, Physical, and Comparative. J. W. Gregory. Blackie \& Son.

(2) The Growth of Europe. G. A. J. ColE. Home University Library: Williams \& Norgate.

(3) Earth Features and their Meaning. W. H. Новвs. The Macmillan Company.

(4) Earth Sculpture; or, the Origin of Land-Forms. J. Geikie. Progressive Science Series : John Murray.

(5) The Scenery of Scotland. Sir A. GrikiE. Macmillan \& Co.

(6) The Scientific Study of Scenery. J. E. MARr. Methuen. 


\section{LAND-FORMS (Contimued)}

\section{Volcanoes and Volcanic Mountains}

THE surface-form of the earth is profoundly affected by the ejection of material from within the crust. Not only is its contour modified, but the presence of ejected material and the frequency and manner of its ejection are of great importance to man in connection with the habitability of various regions. Hence we must make at least an elementary study of the results of volcanic phenomena. The physics of eruptions, the study of underlying causes, and the precise sequence of events belong to the domain of Physical Geology, and they will only receive incidental reference here. We are concerned with the geographical aspect of the subject.

For our purpose a volcano may be defined as a vent from which gaseous and also either solid or liquid materials, or both, are ejected. The important substances to the geographer are the liquid rock-material called lava, and the solid material known by various names.

Lava, or molten rock-material, varies very considerably in chemical composition and in physical properties. All lavas consist chiefly of mixtures of the silicates of alumina, soda, potash, lime, magnesia, and iron oxide. As already explained, those lavas which contain large porportions of the oxides of lime, magnesia, and iron are called basic lavas. These have lower 
melting-points, and thus remain liquid much longer than the acid lavas which have higher melting-points. It is clear, therefore, that the chemical composition and associated physical properties of lavas will have a great influence on the form of accumulation produced by their extrusion from the earth's crust.

Much of the material which was undoubtedly molten within the crust is not ejected in that condition. It has already become solid within the "volcano," and is ejected in explosive outbursts as showers of solid matter of varying form and size. The larger pieces are known as volcanic bombs; smaller and more or less rounded pieces are known by the Italian name, lapilli. Very fine volcanic dust is often ejected in large quantities; the name needs no explanation. Volcanic ash is a vague term used to describe indefinite mixtures of dust, lapilli, and irregular fragments. When this has set and hardened it is usually spoken of as triff; if a number of the fragments of which it is composed are somewhat angular and irregular in form and size, the resultant consolidated deposit is a volcanic breccia.

The fragments in an ash or breccia will obviously show some or other of the characters of the lavas from which they have been derived. Some fragments are glassy, some are ropy. If they are "cindery" in appearance the term scoria is generally applied. The name pumice is used for highly vesicular material, which is clearly the solidified froth or scum at the surface of a lava-flow, the vesicular character being caused by the escape of steam. There are, as may be expected, all sorts of combinations of these various states. Many schools, colleges, and museums have good collections of examples. If at all possible the readershould inspect such a collection.

Extrusion of Lava.-It is now generally accepted that lava may be extruded from two kinds of vents. 
Almost all the lavas which have been poured out within the historic period have come from some localised opening in the crust, round which, as we shall see later, a volcanic mountain is built up. It is believed now, however, that in addition to these localised lava-centres, molten rock-material has often been poured out from long lines or fissures in the earth's crust.

Fissure-lavas.-It seems highly probable that im mense fissure-lavas have been extruded in more than one comparatively recent geological period, if we may judge from the nature and extent of the resulting lavaplateaux. During the Tertiary era lavas of this type were extruded over vast areas in Washington, Oregon, and Idaho, in the great plateau-regions west of the Rocky Mountains. In the same era immense fissurelavas were poured out in the north-west of the Deccan of India, where there are found some of the most extensive lava-flows known. To the same great era belong the plateau-lavas of the far north-west of the British Isles, including Antrim, Mull, and the more distant Faroes. All these great lava-flows are of basic composition. With the possible exception of certain Icelandic eruptions which took place in the eighteenth century, such fissure-lavas or plateau-lavas do not seem to have been formed within the historic period.

Volcanic Mountains; "Volcanoes."-A volcano, as usually understood, begins with a localised crack or opening in the crust, from which material is ejected. As already pointed out, this ejected matter may be gaseous, liquid, or solid. By the accumulation of the solidified rock-material a mountain is in time built up, which, in the nature of things, will be more or less conical in shape. The conical mountain-popularly known as a volcano-may be composed wholly of solidified lava or wholly of fragmentary matter thrown out by ex- 
plosive outbursts, but in the vast majority of cases the conical pile consists of varying mixtures of the two kinds of ejected matter.

Lava-cones.-In severai volcanic regions there are found conical mountains, built up, entirely or almost entirely, of lava. The shape of the cone depends upon the composition of the extruded molten matter. Acid lavas are highly viscous, with a liquidity somewhat like that of thick treacle or tar, and they tend to form dome-like masses. Such domes, of recent formation,

A

$$
\mathrm{Cr}
$$

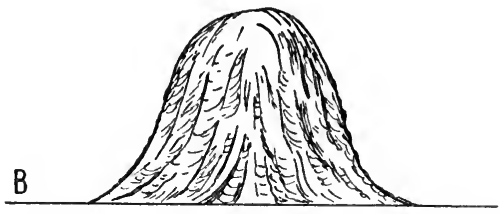

Hig. 8-Hawailan CONe AND "MAMElon."

A. Diagram of a Hawaiian Cone of very basic lava. Crater at $\mathrm{Cr}$.

B. Diagram of a "Mamelon" composed of viscid acid lava.

which occur in the island of Réunion, in the Indian Ocean, are known there as " mamelons." They consist of lava of rhyolitic composition. Cainozoic and Pleistocene lava-cones, which are dome-like in shape, are found in the Auvergne and in Bohemia.

In contrast with the acid lavas, which tend to form domes, the basic lavas flow much more freely, and extend to a greater distance from the vent. The immense lava-cones of the Sandwich Islands, in the Pacific Ocean, are formed of such basic lavas. Mauna Loa consists of little else, and it has an enormous bulk. It rises to 13,000 feet above sea-level, and the inclination of the sides of the cone varies from $4^{\circ}$ to $7^{\circ}$. The extrusion 
of the lava may be judged from the fact that the volcano is over 50 miles in diameter, and that its crater is over Io miles in width. If the dimensions of this immense lava-cone are reckoned from the sea-floor, it is at least 30,000 feet high, and its diameter is about 160 miles. Kilauea, a similar volcano in the same island-group, has a crater even wider than that of Mauna Loa.

Cinder Cones and Debris Cones.-Some volcanoes are made up solely of ejected fragmentary matter. Monte Nuovo, a few miles north of Naples, is a classic example. This volcanic hill was formed in three or four days in 1538 . It is almost perfectly conical in shape, is $44^{\circ}$ feet high, and over 2400 feet in diameter. The structure of the mass may be studied inside the crater, which extends to a depth of about 400 feet from the summit. The cone is built up of fragmentary material, chiefly trachytic scoria and cinder, in which there are occasionally found bits of the sedimentary rock which formed the ground on which the debris cone was built, and through which the eruptive forces had to make a passage. Bits of Roman pottery were found by Lyell during his examination of the mountain in I859. That famous teacher collected in his Principles of Geology excellent contemporary accounts of the formation of this " new mountain," and he also gave a clear description of its structure and relation to neighbouring volcanoes. Similar cinder cones of over Iooo feet high have been known to be built up in a very few hours.

Volcanic mountains, almost or quite exclusively made of debris, are well known in the Auvergne, in Java, and in Mexico. In Java there are mountains reaching over 9000 feet in height, with a diameter of ro miles, which probably consist of fragmentary material. There is a series of small cones on the Mexican plateau, 
of which Jorullo is perhaps the best known. These consist of cinders, scoriæ, and similar rock-fragments, and were formed for the most part in a single series of eruptions in I759. Izalco, in San Salvador, Central America, is another famous example of a cone, mostly built of volcanic debris. This new volcano was apparently first formed in I769. It is still active, and has now reached a height of about 2600 feet.

Composite Volcanic Mountains.-Most volcanoes consist of successive lava-flows and alternating showers

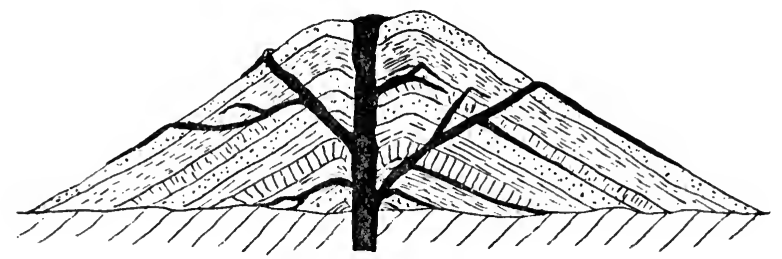

Fig. 9.-Diagrammatic Section across an Ideal Composite Volcano.

The different kinds of shadings represent successive additions to the volcano. The composite volcano is represented as resting on a floor of rocks, through which the lava is forced up from some reservoir below.

of volcanic debris, and represent the efforts of a long series of eruptions. The structure of such a composite cone may be illustrated diagrammatically by such an ideal section as that given in Fig. 9. Vesuvius has obviously such a structure, for its history is known for nearly two thousand years, and the successive lavaflows and deposits of ash, lapilli, etc., have been very carefully studied during the last one hundred and fifty years. Enough is known of the history and structure of Etna, Teneriffe, Cotopaxi, Popocatapetl, Fujiyama, and many other volcanoes to assure us that their 


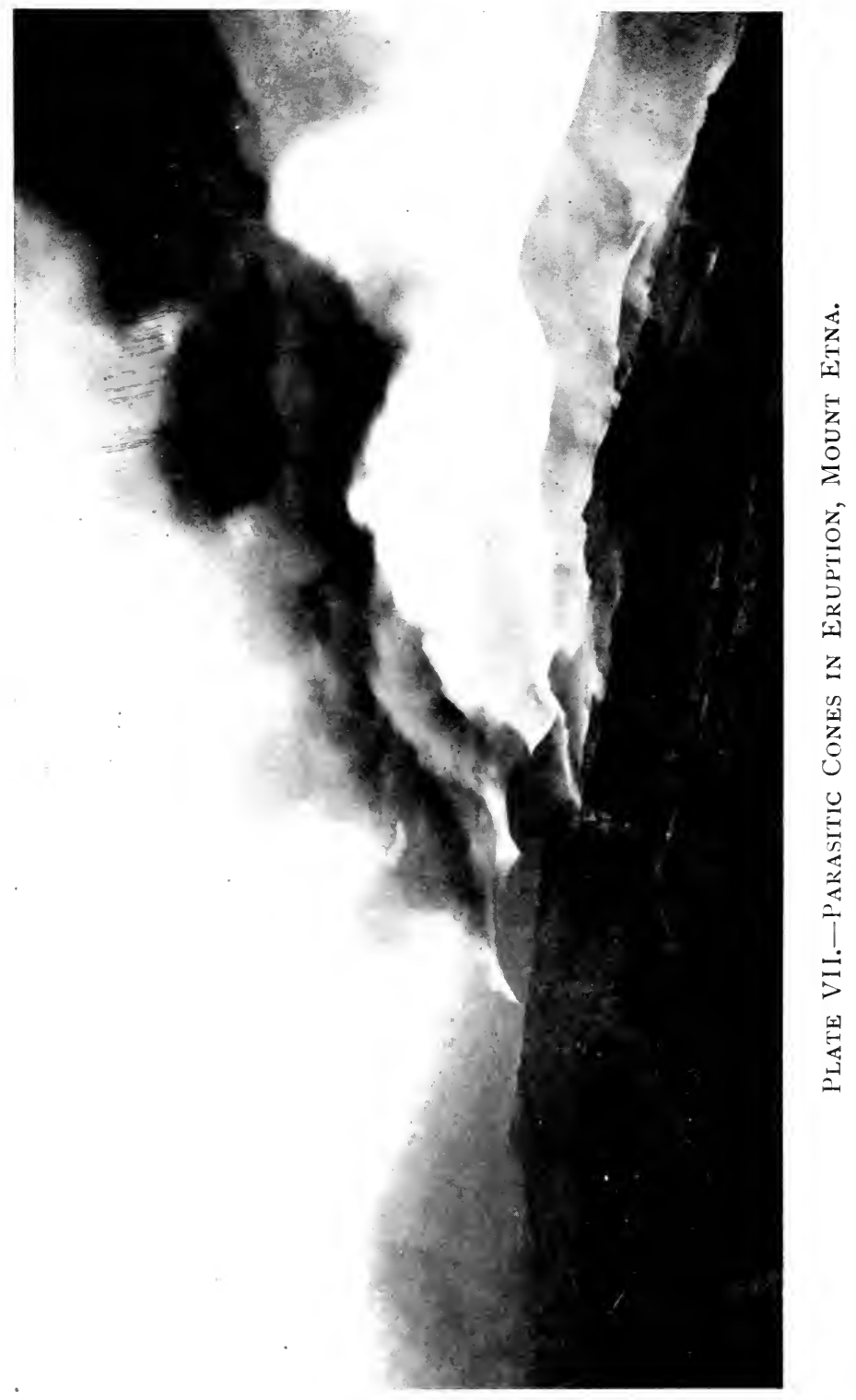




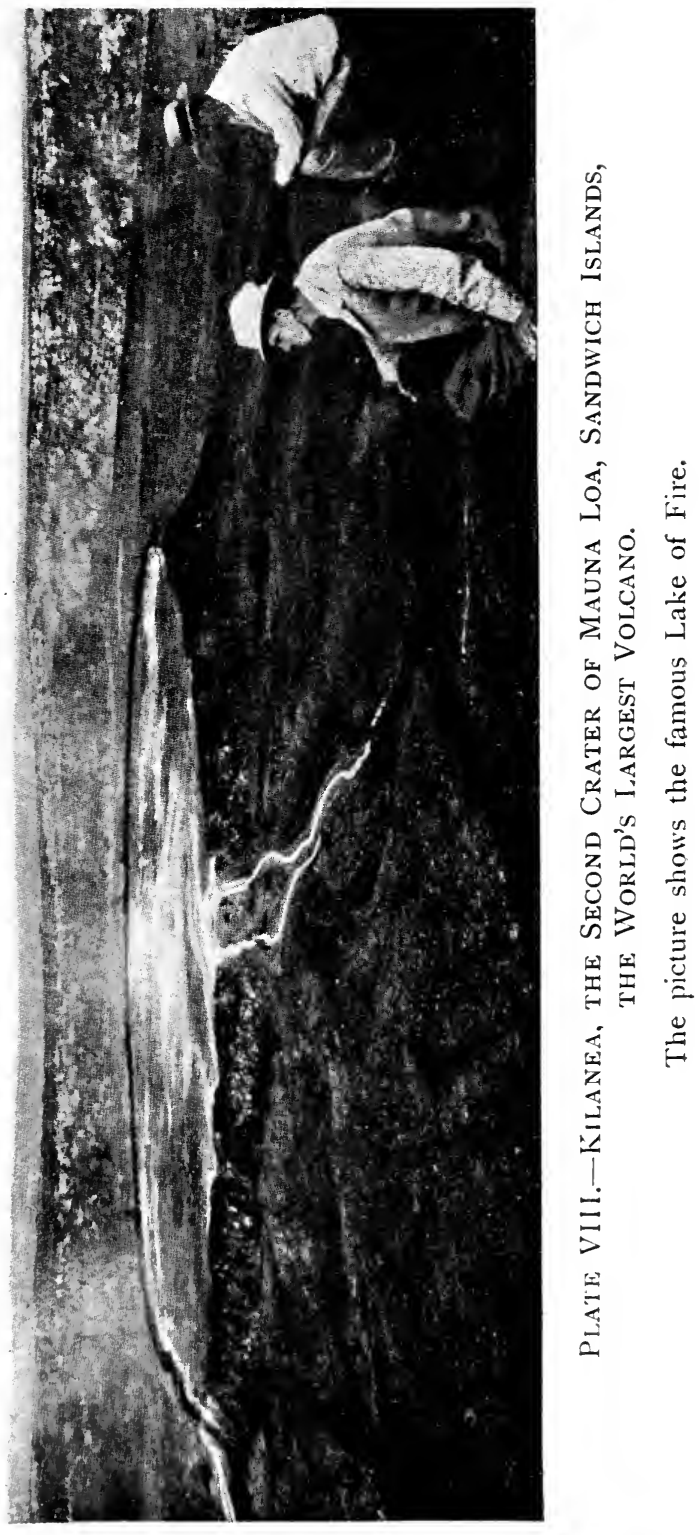


general structure is the same as that of Vesuvius. It has very frequently happened that the internal structure of a volcano might have remained doubtful were it not that erosion by frost, rain, and small streams has proceeded sufficiently far to reveal the successive lavas and showers of debris of which the mountain has been built up.

The building of a large volcano has often commenced with the ejection of cinders and other fragments, and a debris cone has been formed. This has been followed by the ejection of lava, which has either welled up and flowed over the rim of the crater, or has forced a way through cracks in the sloping sides of the mountain. As the volcano has grown bigger the explosive forces have been unable to eject material from the summit of the crater (which has been closed by solidified lava and debris), but have been powerful enough to blow away one side, or a portion of one side, of the mountain. Thus the internal structure of a volcano is often completely revealed. The original greater Vesuvius, known as Somma, was thus breached by the historic outbursts of A.D. 79. The modern active cone is contained within the broken crater of that greater volcano, Somma. Several such breached volcanoes, of a much smaller size, are to be seen in the volcanic Auvergne, and similar structures are common elsewhere.

The structure of a composite cone is frequently further complicated by the extrusion of lava and the ejection of debris at various points on its flanks. Thus a small volcano is built, reproducing most of the features of the parent cone. Such parasitic cones are a wellknown feature of Europe's greatest modern volcanoEtna, in Sicily.

Not only do composite cones constitute the majority of volcanoes, but nearly all the larger volcanoes are presumably of this type. The following may be men- 
tioned as examples: Etna, in Sicily, ro,700 feet; Teneriffe, in the Canary Islands, 12,000 feet; the beautiful cone of Fujiyama, in Japan, I2,400 feet; the perfectly formed extinct cone of Shasta, U.S.A., over I4,000 feet; and Cotopaxi, in South America, I9,60o feet. The last named is possibly the highest active volcano in the world. The above are, of course, only selected examples.

It has been mentioned that subsequent erosion may considerably modify the original conical shape of the volcano. This destructive erosion may continue to such an extent that a mountain which is obviously built of igneous matter may show very little indeed of its original shape. Denudation may even proceed so far that little except the central plug of solidified lava - that which filled the neck - is left. The famous trachytic plug of Mont St. Michel in the Auvergne, and the basic neck, Castle Head, Keswick, are wellknown examples of such volcanic necks or plugs. The subject of the denudation of volcanoes will receive further mention in the next chapter.

Distribution of Volcanoes.-Mercalli, an Italian geologist, has estimated that there are $4 \mathrm{I} 5$ volcanoes on the earth's surface, of which 23I have been active since the year I800. Of these latter the distribution is as follows :

America, 76.

Eastern Asia, 39.

Malay Archipelago, 49.

"South Seas," 27.

Atlantic Islands, 20.

Africa, 7, including 2 in Réunion.

Europe, 8.

Continental Asia, ${ }^{1} 3$.

${ }^{1}$ Excluding the eastern peninsulas and islands. 
Many of the active volcanoes are situated on or near the edges of continents, very frequently on peninsulas or islands. The Pacific Ocean is almost girdled by volcanoes, "The Ring of Fire of the Pacific," so often mentioned in books on geography. It is important to notice that round the Pacific are so many of the long lines of younger fold-mountains mentioned in Chapter II., and there can be little doubt that there is some connection between these and the volcanoes. The Atlantic Ocean has no similar series of Alpine mountains with steep, continental edges, and there is no Atlantic girdle of volcanoes. The subject is discussed at length in some of the more advanced treatises on Physical Geography, and in works on Volcanoes.

Of the $4 \mathrm{I} 5$ active and extinct or dormant volcanoes mentioned above no less than 337, or 88 per cent., are either on the coasts of the Pacific or on islands in that great ocean. It is obvious that, in the present geological epoch, the Pacific Hemisphere is the chief seat of volcanic activity. To trace out the coastal series of the Pacific we may begin in North Island, New Zealand. From there we may follow an almost unbroken series of volcanoes, through the New Hebrides, the Philippines, Formosa, the Loo Choo Islands, the Kurile Islands, and Kamchatka. The series is interrupted at the Aleutian Islands to be recommenced on the eastern side of the Pacific, where it may be traced on the western side of the two Americas as a less continuous line. From latitude $62^{\circ} \mathrm{N}$. in Alaska, to latitude $22^{\circ} \mathrm{N}$. in Mexico, recent volcanic rocks are widely spread, and volcanoes recently extinct are numerous, but there is little present-day volcanic activity. In Mexico begins that New World region of volcanic activity, which may be traced with some 
interruptions to the southern limits of the American continent. Six sub-regions are usually distinguished :

(I) The Mexican sub-region:-lat. $22^{\circ} \mathrm{N}$. to lat. $18^{\circ} \mathrm{N}$.

(2) The Central American sub-region:-lat. $I 5^{\circ} \mathrm{N}$. to lat. $9^{\circ} \mathrm{N}$.

(3) The equatorial sub-region of Columbia and Ecuador:-lat. $5^{\circ} \mathrm{N}$. to lat. $3^{\circ} \mathrm{S}$.

(4) The Peru-Bolivia sub-region:-lat. $I 5^{\circ} \mathrm{S}$. to lat. $23^{\circ} \mathrm{S}$.

(5) The Chile-Argentina sub-region :-lat. $23^{\circ} \mathrm{S}$. to lat. $42^{\circ} \mathrm{S}$.

(6) The Patagonia-Tierra-del-Fuego sub-region :lat. $42^{\circ} \mathrm{S}$. to lat. $56^{\circ} \mathrm{S}$.

This Pacific girdle of volcanoes seems to be continued into the Antarctic continent where Mount Erebus and Mount Terror occur.

As already mentioned there is no similar girdle of volcanoes round the Atlantic coasts, and the coasts themselves are quite different in type, there being no long series of younger fold-mountains facing the Atlantic Ocean. In the West Atlantic are the volcanoes of the West Indies, which, beginning near those of Mexico, extend through the West Indian Islands. Mercalli gives nine volcanoes in the Antilles, of which six are active. Soufrière and Pelée are well-known, because of their recent activities.

Extending lengthways along the Atlantic, from Jan Mayen in the north, through Iceland, the Azores, the Canaries, and Cape Verde Islands, is an interrupted volcanic belt, containing thirty-nine volcanoes, of which twenty are said to be active. The majority of these volcanoes are in Iceland.

In Southern Europe there are the famous volcanoes of Italy, Sicily, and the adjacent islands, and those 
of the Grecian Islands. These are the best-known volcanoes in the world, Vesuvius, Stromboli, and Etna having been especially well studied.

Volcanoes, both active and extinct, are found in the Caucasus-Armenian region, where the mighty Mount Demavend in the Elburz range is over I9,000 feet high. This mountain seems to have reached almost the last stages of volcanic activity.

A fine series of volcanoes extends from the Bay of Bengal through Sumatra, Java, and the lesser Sunda Islands to join the great Western Pacific belt, and includes eighty-nine volcanoes, of which forty-nine are considered to be active. The most violent explosive outburst of modern times was that of Krakatoa in August I883, when the greater part of a volcanic island was literally blown away. Krakatoa is in the Sunda Strait, between Sumatra and Java.

Volcanoes and Fold-Mountains.-From what has been said already it is clear that there is some intimate connection between the existence of active volcanoes and the occurrence of long lines of modern Alpine mountains. When we take into account volcanoes which have been active in later Tertiary times, in addition to those active in recent times, the connection becomes more striking. It was pointed out in Chapter II. that most of the Italian and Sicilian volcanoes occur on the inner side of the curve formed by the very modern Apennine Mountains. The Apennines are closely associated with the Atlas and Sierra Nevada chains, the whole forming a great Alpine curve, enclosing a deep sunken block of the earth's crust. There were volcanoes in the neighbourhood of these mountain chains in the Tertiary era. It has recently been shown that there is a remarkable resemblance in chemical composition between the volcanic rocks of different 
parts of this Western Mediterranean region, possibly indicating something approaching a common origin. The rocks belong to the same " petrographical province."

Similarly, inside the long curve of the Carpathians are the numerous extinct volcanoes of Hungary and Transylvania, of which those of Schemnitz, the Matra, Tokay, and the Munkacs district are the best known. The extinct volcanoes of Teschen, in upper Silesia, and Bohemia are outside the Carpathian curve. Professor Judd showed, many years ago, that there is a sharp contrast in composition between the igneous rocks on opposite sides of the Carpathian chain of fold-mountains. The rocks belong to different petrographical provinces. This is another way of emphasising the close connection between the production of tangential folds in the crust and the development of igneous activity. These phenomena, so important in geography, are evidently due to some common cause. In addition to the above examples, the same intimate connection may be illustrated from many parts of the world.

Volcanoes and Rift-Valleys.-One of the more remarkable cases, of a somewhat different kind from those discussed above, is that of the famous rift-valley of East Africa. This well-known line of fracture extends from the north of Syria, through the Dead Sea, the Gulf of Akaba, the Red Sea, across Abyssinia, past Lake Rudolf, to the Zambesi region. Volcanoes, recently extinct or dormant, are associated with this great fracture at various points, more especially in the Red Sea region, where five active and seven extinct or dormant volcanoes have been enumerated. Farther south are Teleki, which was in full eruption in I894; Kenia, an extinct volcano over I8,000 feet high, whose cone is built of lavas and tuffs; and Kilimanjaro, nearly 20,000 feet high, with its peaks clothed in 
snow. A much smaller volcano, not far from the great and probably extinct Kilimanjaro, was in eruption in $\mathrm{r} 88 \mathrm{o}$.

Volcanic action accompanied the formation of other rift-valleys, for example, those of the Rhine and the Midland Valley of Scotland. These rift-valleys are of very different ages, but in each case volcanoes were formed as a consequence of, or at least in connection with, the sinking of portions of the crust. Other illustrations are unnecessary; enough has been said to show that volcanoes are intimately associated both with folding and faulting of portions of the earth's crust, and that both the types of movement mentioned in Chapter II. may be accompanied by some manifestations of volcanic activity.

Volcanoes and Earthquakes.-It will be noticed that the great earthquakes mentioned in Chapter II. occurred in regions where active or recently extinct volcanoes occur. The close association of volcanoes and earthquakes is notorious, and yet it is not quite so complete as many are tempted to think. Every region of active volcanoes is subject to earthquake shocks of considerable intensity. But the converse is not true; every earthquake region is not at present volcanic. Some of the greatest earthquakes of modern times have occurred in non-volcanic regions. As instances may be mentioned the great earthquake of Lisbon in $\mathbf{1 7 5 5}$, and the very numerous and often violent earthquakes of North-Western India. These are far from any region of modern volcanic activity. The subject is mentioned here in connection with the distribution of volcanoes, and their association with areas of movement in the earth's crust. The close study of the fundamental relation between the two phenomena belongs to the science of geology. 
Minor Volcanic Accumulations.-Mud-Volcanoes.Hot water containing much mud in suspension is ejected from fissures in many parts of the world. The mud is usually derived either from sedimentary argillaceous rocks or from fine-grained volcanic ash. Small conical hills with a distinct crater may thus be built up. Such mud-volcanoes are found in regions where volcanic activity is supposed to be on the wane. Some examples are-Baku, on the borders of the Caspian Sea, Sicily, Iceland, Central America, New Zealand, and some of the islands of Malaysia. These small "volcanoes" are of little geographical significance, though of great interest in connection with theories of igneous action.

Geysers.-In many regions hot water only is ejected at regular or irregular intervals. This contains dissolved silica and carbonates, and thus deposits of these substances may be formed. A small mound may thus result in which is a funnel or pipe from which the hot water is thrown out. The Great Geyser of Iceland is the type, and the name has been applied to similar hot-water "volcanoes" elsewhere. If the hot water is ejected from linear fissures and not from a funnel or pipe, terraces rather than cones may be formed. The forms of the siliceous sinter deposits or of calcareous tufa may obviously be most varied. Those of the Yellowstone Park, in North America, and the once famous terraces of North Island, New Zealand, are good examples. The most famous geyser regions are Iceland, Yellowstone Park, and North Island, New Zealand, with others in various parts of the world. Even the valley of the Rhine possesses a small geyser. These deposits are, again, of little geographical importance, but the hot springs from which they are derived throw light on the physics of volcanic action. 


\section{BIBLIOGRAPHY}

(I) Volcanoes. J. W. JUDD. International Scientific Series: Kegan Paul, Trench \& Co.

(2) Volcanoes. T. G. Bonney. John Murray.

(3) The Natural History of Igneous Rocks. A. HARKER. Methuen \& Co.

(4) Ancient Volcanoes of Great Britain. 2 vols. Sir A. Gerkie. Macmillan \& Co. 


\section{LAND-FORMS (Continued)}

Mountains of Erosion, Residual Mountains

ALL the land-forms discussed in the preceding chapters are attacked by the agents of erosion and denudation. In various ways and in different degrees Alpine mountains, block-mountains, plateaux, volcanic accumulations are all attacked by wind, rain, frost, rivers, glaciers, and the sea. The mechanical and chemical action of the atmosphere, the solvent and chemical power of water, the expansive force exerted by water in freezing, the mechanical action of water as rain or rivers, the action of ice and water in glaciers, the force of gravity, the heat of the sun-these act and interact in an infinite variety of combinations. The rocks of which the land-forms are made are frittered away. The word erosion ${ }^{1}$ expresses very well these destructive processes. The removal of the material disintegrated or set free by erosion and the uncovering or exposure of the rocks below is usually described as demudation. ${ }^{1}$ These two complementary processes profoundly modify the land-forms, and produce in them a series of new features. The study of the forces and agents of erosion and denudation belongs to Physical Geography and Geology; we shall, as in the preceding chapters, confine

${ }^{1}$ Latin : erodere, to gnaw or eat away; -e, out; rodo, I gnaw ; denudare, to strip bare; $d e, \underset{58}{\text {; }}$, nudus, naked. 
ourselves to these results which are considered to be of considerable geographical significance, always bearing in mind the conception of Geography, which is the main thesis of this book.

The amount and manner of erosion and denudation, and the rate at which the dissection of the land-forms takes place, will clearly depend upon the following factors :

(a) The nature of the rocks ; their resisting power, depending upon the nature of the individual rockparticles or minerals, and the cementing material in the case of certain fragmentary rocks; their permeability or impermeability to water; and whether much jointed or not;

(b) the position and relationships of the rocks in the field, including in this the dip of the sedimentary rocks, the alignment and mode of occurrence of the igneous rocks; whether the rocks are faulted or not, and, if folded, whether slightly or intensely ;

(c) the intensity of the forces and agents of erosion and denudation, including in this the climatic conditions, such as amount of rainfall, prevalence of much frost, and considerable variations in temperature; and the time during which the original land-forms have been subject to the attack of these forces.

It will be seen in the sequel that what are usually described as residual mountains, mountains of erosion, or mountains of denudation are stages in a great cycle of processes ; and, indeed, these mountains are usually a late stage. The "cycle of erosion" here referred to begins with a newly upheaved land-surface, and continues until erosion and denudation have worn it down to a plain again. It will be convenient to discuss in this chapter some early stages in cycles of erosion 
though the land-forms produced are not mountains at all in the ordinary sense. They are, however, just as important to the geographer, and their study may well be included in this place. We shall study a series of concrete examples which illustrate general principles.

The Dissection of the Loess of China.-The loess of the north-west and west of China is a fine-grained yellowish loam, ${ }^{1}$ sometimes nearly 3000 feet in thickness; it covers an area of over 200,000 square miles in the basin of the Hoang-ho or Yellow River. This immense deposit chiefly consists of very fine grains of quartz and calcium carbonate, and seldom appears to be appreciably stratified. Similar deposits occur in other mid-continental regions, but the finest example is in the steppe region on the north-eastern side of the immense plateau-deserts of mid-Asia. Most geologists, therefore, follow Richthofen in believing that the deposit is wind-borne, and that the extremely small grains of which it consists have been carried from the high-pressure region of the great continent by the steady winter monsoon winds, the process having possibly continued since the establishment of the present general conditions about the beginning of Pleistocene time.

This soft, homogeneous deposit has been dissected in a remarkable manner. The plateau, which it forms, has been cut up by the rivers into blocks, which are separated by a labyrinth of deep valleys with perpendicular or overhanging walls. As the loess, owing probably to slight variations in the nature of the deposit, tends to be cut back almost horizontally on certain horizons, the result is, in places, the formation of a remarkable series of terraces on the flanks of the otherwise perpendicular gorges. The vertical walls of the deep valleys above

1 Loam; cf. German, lehm, a calcareous, sandy clay. 
these terraces have provided ideal conditions for the cutting of vast numbers of the cliff dwellings for which these regions have long been famous.

The "Bad Lands" of Dakota.-In South Dakota, and adjoining parts of Wyoming, there is a wide region occupied by soft horizontal strata, chiefly clays and soft sandstones of Mesozoic Age. The rainfall is not more than fifteen inches per annum, and occurs mostly in winter. The summer is dry and hot, and the smaller streams are then dried up. The soft, horizontal strata have been dissected by numerous steep-sided channels, enclosing " mesas " or blocks of land which are accessible from each other only with some difficulty. The region thus merits the name " mauvaises terres pour traverser" given to it by the early French explorers. Hot and waterless in summer, with irritating alkaline dust blowing, the cliffs and plateau-surfaces almost destitute of vegetation, these deeply dissected lands are of profound interest to the student of Physical Geography, and also to the palæontologist who finds in the soft strata some of the most perfect and wonderful remains of extinct animals yet known.

The Cañons of Colorado.-Probably the most magnificent examples of deep gorges cut in approximately horizontal rocks are the stupendous cañons west of the Rocky Mountains. A vast succession of strata of age varying from Palæozoic to late Mesozoic, capped in places by immense lava-flows, has been dissected by the Colorado and other rivers. The region is a dry one, and there is little of the subaerial weathering which goes on in humid localities. The rivers are fed from the snows of the Rocky Mountains, and flow through the almost rainless plateaux, cutting deep gorges, the sides of which do not recede at the rate they would if the atmosphere contained much moisture, and if the 
ordinary erosion of rain and frost took place. This vast plateau area of almost horizontal strata stands many thousands of feet above the base level of erosion, and so the gorges reach an enormous depth, in places as much as 6000 feet. Immense dissected blocks of the sedimentary and volcanic rocks are the result; these have also been termed mesas by the early Spanish explorers and settlers.

Cañon-like Gorges in other Regions.-Gorges of somewhat similar type are found in many parts of the world, but nowhere on so grand a scale. A remarkable dissected country is that of Southern Abyssinia. The rocks there are chiefly volcanic-trachytes, basalts, and tuffs, and lie almost horizontally. The volcanic plateau, rising to 7000 feet or more above sea-level, has been dissected into a remarkable system of blocks similar to the mesas already mentioned. The rocks, owing to differences in texture at different levels, and to their general horizontal alignment, show magnificent terraces, with mighty walls of 3000 feet rising sheer from them. Some of the cañon-like gorges reach 5000 feet in depth. The summits of the dissected blocks-called "Ambas" in that country-and the less easily accessible terraces, are often crowned by fortresses, or are the seat of monasteries.

We may also instance here the rocks of the Nieuweld plateau in South-East Africa which culminates in the deeply dissected Drakensberg. The rocks are shales, grits, and sandstones, covered by more-resistant igneous rocks. The Drakensberg high plateau has been cut into a series of tabular mountain-blocks, sometimes having the appearance of gigantic fortresses. Giant's Castle, 9000 feet above sea-level, is a well-known example. In the neighbourhood of Mont Aux Sources, on the north-west border of Natal, the magnificent gorges of 
the upper Tugela River are quite cañon-like in character. The gorge known as "The Great Cañon" is five miles in length below the famous Tugela Falls, and in places is not more than 40 feet wide. There are many cliffs which rise almost vertically for thousands of feet; in the middle of one such series the main falls of the Tugela plunge over 2000 feet in three steps. In the Champagne Castle region a little to the south of Mont Aux Sources the Little Drakensberg is separated from the main range by a gorge 7000 feet deep. Throughout the whole of the Drakensberg, but especially in the three regions mentioned, the dissection of the plateau has left magnificent examples of isolated mountains of erosion or denudation; these stand out from the serrated edge of the plateau as giant outliers, separated from each other by the smaller tributaries of the Tugela and other rivers.

We may now turn to similar gorges and dissected blocks, cut out of limestone plateaux. The fine gorges of the Tarn in South-central France may be especially mentioned. The rainfall is there considerable, but the well-jointed limestone allows the rain-water to pass through to form underground streams, and the direct downward cutting of the main stream therefore proceeds more rapidly than the erosion of the side walls. In this way deep gorges are cut in the limestone rock. The smaller gorges of the carboniferous limestone regions of Britain, notably those of the West Riding of Yorkshire, Derbyshire, and the Mendips, are similar to those of the Tarn. The jointed limestone allows of the production of gorges with more or less vertical walls.

Saxon Switzerland and the Swabian Jura.-In the region known as Saxon Switzerland, on the borderland of Bohemia and Saxony, there are well-bedded Cretaceous 
grits which have been dissected into plateau-like blocks by systems of vertical fissures. One of the best examples is the gorge by which the Elbe passes through from Bohemia to Saxony, and which has been described as a good example of a cañon. In the Jurassic region of Swabia the Danube and its northern tributaries, and the feeders of the Neckar, have cut deep gorges, in the bottom of some of which rivers still flow, while many are " dry valleys." In the northern part of this dissected land there are prominent rock-masses with precipitous faces, standing out from the gently sloping tableland as islands or peninsulas.

In regions where there is a moderate or heavy rainfall, and where consequently frost and rain may erode the sides of the river-valleys, the cañon character becomes modified. The valley becomes relatively wider, and the intermediate blocks of land lose something of their plateau character. These effects are best illustrated and studied in regions where the strata are horizontal or only gently inclined, and where sandstones and grits form a considerable portion of the rocks.

The Plateaux of the North Pennines.-There are two distinct Pennine regions. The moorlands north of the Aire Gap have a structure somewhat different from that of the Southern Pennines. The Northern Pennines consist of a series of crust-blocks, bounded to the west by prominent faults. The four chief faults are the Tyne, the Pennine, the Dent, and the Craven, two of which, the Pennine and the. Craven, form distinct features in the Northern Pennines. The positions and relations of the various structural divisions will be better understood by reference to a simplified geological map in which the great faults are shown somewhat diagrammatically (see Fig. Io).

There are, it will be seen, three great blocks of Car- 


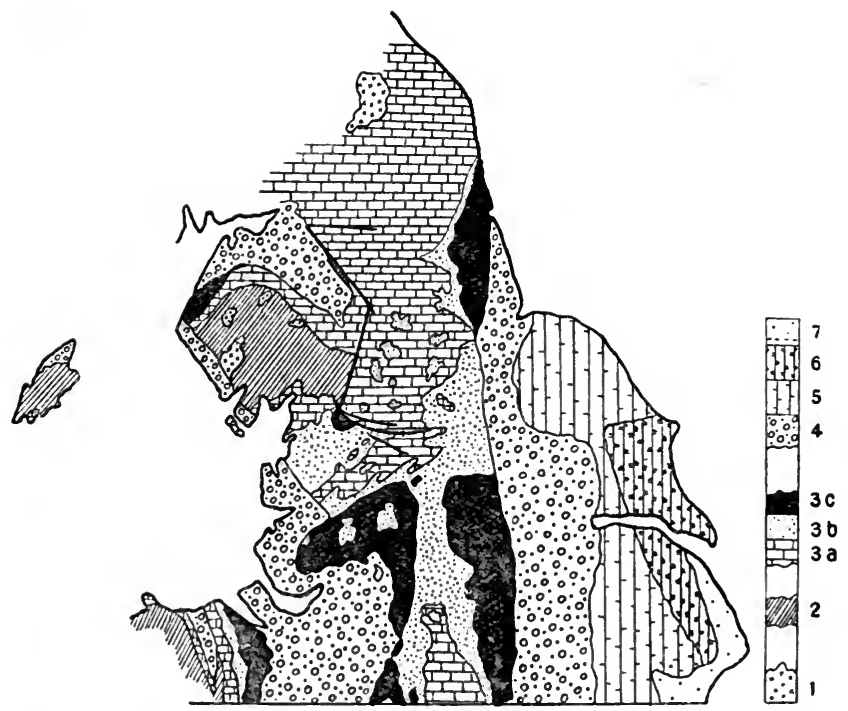

Fig. io.- $\AA$ Simplified Geological Map of the Nortrh of England, to illustrate the Geographical Divisions.

I $=$ Granite masses. $2=$ Lower Palæozoic Rocks. $3 a=$ Carboniferous Limestone. $3 b=$ Millstone Grit. $3 c=$ Coal Measures. $4=\mathrm{New}$ Red Sandstone (Permian, Trias). $5=$ Jurassic Rocks. $6=$ Cretaceous Rocks (Chalk, etc.). $\quad 7=$ Recent deposits.

Note the great Fault Systems of the Northern Pennines. The Faults, reading in order from north to south, are: Tyne Fault, Pennine Fault, Dent Fault, Craven Fault. Each of these faults is more or less complex or compound in structure.

The chief, clearly-defined Geographical divisions, as determined by the rocks, rock-structure, and rock-position, are: The Northern Pennines, chiefly Carboniferous Limestone, with denudation relics of Millstone Grit ; the Southern Pennines, chiefly Millstone Grit, with the two great coal-field systems on the flanks; the Lake District system of Older Palæozoic Rocks, with masses of Granite, and with a rim of Carboniferous Rocks; the Bowland Fells, between the Craven Fault and the North Lancashire Plain, Millstone Grit and Carboniferous Limestone, with the little Ingleton coal-field at the north-eastern corner; the large coal-fields determining the great industrial areas of the north; the New Red Sandstone plains, Lancashire and Cheshire, North-Eastern, and Vale of Eden; the North York Moors, Jurassic Rocks; the Yorkshire Wolds, Chalk rock ; the Lincolnshire Scarps and Wolds; and the part of the Fenlands shown on the map. 
boniferous strata, in which the dominant formation is the Carboniferous Limestone, with irregular cappings of Millstone Grit. These may be called the Cross Fell, the Dent, and the Penygent blocks. Each of these, but more particularly the last-named, illustrates very clearly the dissection of a plateau and the production of well-defined residual mountains. An east and west section-somewhat diagrammatic-through the Craven Fault, Ingleborough, Penygent, and Great Whernside illustrates the whole structure remarkably well, and

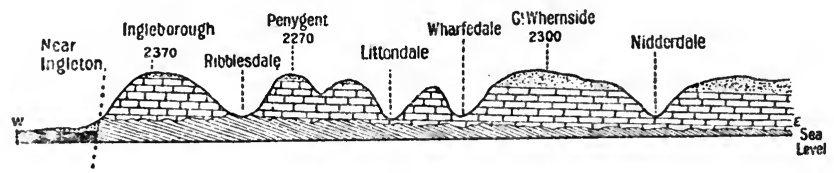

Fig. il.-Diagrammatic Horizontal Section across the Craven fault and the Pennine Moors to the East.

On the east of the fault Millstone Grit overlies Carboniferous Limestone, and the latter lies unconformably on Lower Palæozoic Rocks, which come to the surface in Ribblesdale. On the west of the fault, near Ingleton, Permian Rocks (New Red Sandstone) overlie Coal Measures. The strata are shown diagrammatically, with the vertical scale exaggerated.

shows the relics of the Millstone Grit as the caps of the three conspicuous mountains named, and rising from the platform of the Carboniferous Limestone into which the rivers Ribble and Wharfe have cut their valleys. In Ribblesdale, the river in its cutting-down has reached the Older Palæozoic rocks below the floor of the Carboniferous Limestone.

In the case last considered the residual mountains constitute only a fraction of the original tableland of Carboniferous rocks out of which they have been carved. The lower strata of the Carboniferous Limestone are now in a comparatively early stage of dissection, but 


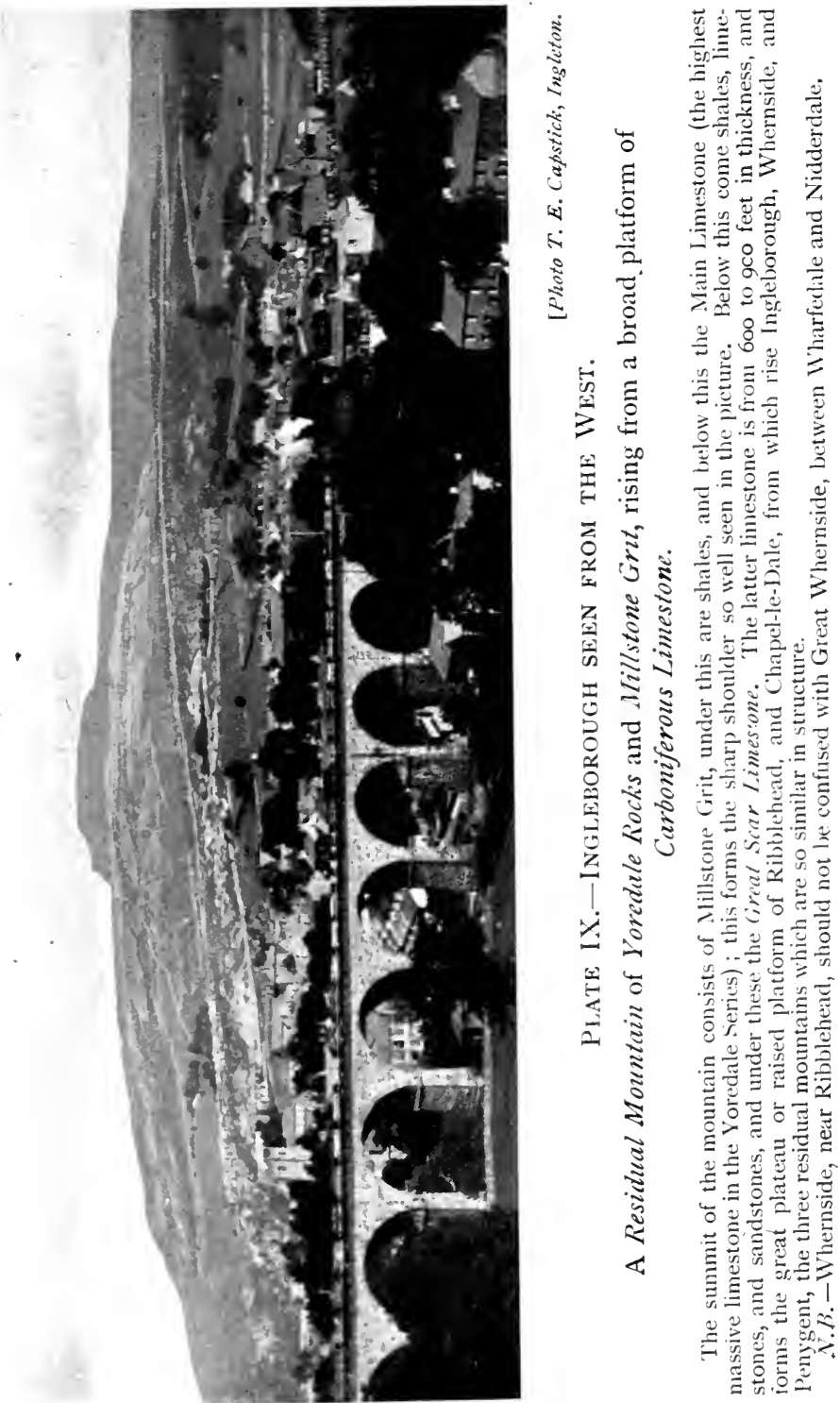




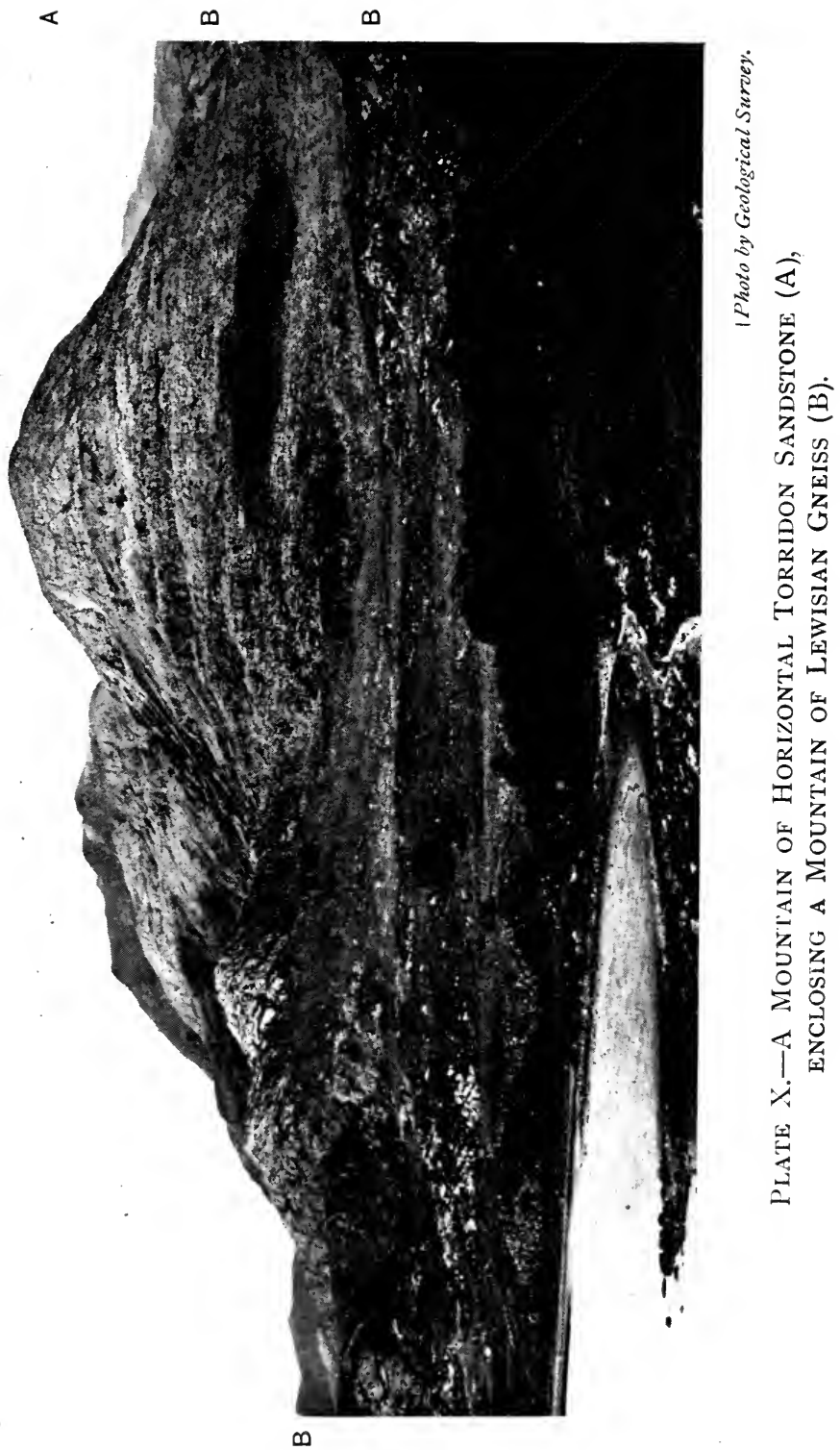


of the upper beds of the same formation very considerable portions have been removed; the Millstone Grit caps of the mountain-masses are only a very small remainder of the once vast extent of that formation. Quite possibly there have once been newer strata overlying the whole of those at present exposed,-Coal Measures, Permian and Mesozoic rocks,-but, if so, they have been completely removed by denudation. It is clear, therefore, that erosion and denudation have proceeded to a comparatively advanced stage. We may now consider cases where the process has reached a more advanced stage.

The Torridonian Mountains of Scotland. - In the extreme north-west of Scotland there are many bold mountains which consist of almost horizontal grits and quartzites of the Torridonian series. These rocks are preCambrian sediments, and are thus of very great geological antiquity. They overlie unconformably the Archæan schists and gneisses of the North-Western Highlands. The pre-Cambrian sediments have clearly once extended over a wide area, but only the merest relics are now left. Through long geological ages erosion and denudation have continued, and nearly the whole of the once widespread strata, 7000 to 8000 feet in thickness, has been removed. A number of isolated mountains may be seen in Sutherland and Ross-shire, the lower parts of which are composed of almost horizontal Torridon Sandstone, capped by bold cones of quartzite, the whole resting on a much denuded platform of Archæan rocks. These are true residual mountains, and the region is now in a late stage of the cycle of erosion.

"Monadnocks."-Similar true residual mountainsthe relics of the dissection of some kind of upland or plateau-are found in many parts of the world. An 
example, which has become famous, is Mount Monadnock, in New Hampshire, U.S.A. This is an Archæan peak of about 3500 feet above sea-level, which now stands up as an isolated mass, and a prominent landmark-the result of the almost complete destruction of an old plateau. The name of this residual mountain has been proposed by Prof. W. M. Davis as a technical name by which all such remnants of dissected uplands should be known. The name is not a euphonious one, but it has already won a place, if a somewhat grudging one, in geographical literature.

Dissection of a Dome-The English Lake District. -In the examples we have studied up to this point the strata have been, for the most part, horizontal, or only dipping at a low angle. We now come to the study of the dissection of upland regions where the rocks are much folded. The first illustration is the English Lake District, a region which furnishes excellent illustrations of residual mountains. Such mountains as Scafell, Helvellyn, and Fairfield, for example, stand out comparatively isolated; but they are clearly relics of a once continuous mass. The Lake District consists essentially of a central region of folded and faulted Older Palæozoic rocks, partly surrounded by a girdle of Carboniferous rocks, with another incomplete outer girdle of New Red Sandstone rocks. The central mass has been uplifted into a sort of elliptical dome, somewhat like a shallow spoon, convex side upwards. The axis of the upfold runs from east to west, and the drainage thus shows a sort of radial arrangement with more emphasis on north and south than on east and west directions. Dr. Marr has shown that the uplift of this dome probably took place in Miocene times. At that period, the older rocks were possibly covered with Jurassic and Cretaceous 
rocks. The drainage then set up has been inherited by the present much-folded and faulted central lake region, some of the complex folding and faulting of which belongs to a much earlier period. It is on this account that the river-valleys so often cut across the grain of the rocks. Aided by numerous faults, the drainage of this region of heavy rains has cut deeply into the dome and produced the striking assemblage of mountains and deeply trenched valleys. It ought to be added that Dr. Marr is of opinion that erosion by glaciers has played a considerable part in the gouging

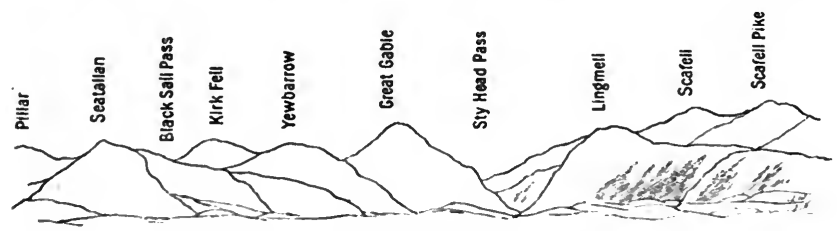

Fig. 12.-A Dissected Dome.

A sketch of the profile of some Lake District mountains as seen from near Seascale. The deep valley is Wastdale, with the famous screes on the slopes above Wastwater

out of some of the valleys. The general question of glacial erosion is still one of the thorny questions of geology, but Dr. Marr has paid so much attention to the physical history of the Lake District that his opinion must carry considerable weight.

Snowdon as a Residual Mountain. - From this brief summary of the dissection of a dome we may conveniently pass to the study of Snowdon as a type of residual mountains of another character, but in many respects not unlike some of the Lake District mountains. Just as Dr. Marr has interpreted for us the structure and the history of the Lake District, so Prof. Fearnsides has done for the mountains of North Wales. 
He has taught us the successive phase in the history of this interesting region. In the three long periods of Older Palæozoic time - the Cambrian, Ordovician, and Silurian-the building up of the material took place. There are immense thicknesses of sedimentary rocks of Cambrian, Ordovician, and Silurian Age, and, in addition, there are volcanic rocks formed in the Ordovician period. These include acid and intermediate lavasrhyolites and andesites-and thick deposits of volcanic ash, of which a good example is the well-known fossiliferous ash which forms the summit of Snowdon. Most, if not all, of the volcanic rocks of the Snowdon district are of submarine origin, and both beds of volcanic ash and lavas are interbedded with ordinary sediments. These Older Palæozoic periods were, so far as North Wales is concerned, practically one long marine epoch when immense thicknesses of their rocks were laid down.

The second phase in the history of Snowdonia began at the end of Silurian or in early Devonian time. The formation of the folded Caledonian Alps in the Devonian continent has already been mentioned. The modern Alpine ranges have their fringing-ranges or foreland mountains, such as, for example, the Jura; so the Caledonian range of Devonian times had its foreland mountains. Such a "Jura range" seems to have extended along a line through Anglesea and the Southern Lake District. The production of this foreland range included what is termed the regional folding of the rocks of Snowdonia. This sub-stage was followed, probably in later Devonian time, by intense local folding, including much compression and faulting. Taking these two correlated processes, regional folding and local crumpling, as one great compound phase, it may be said that in the Devonian period the larger anticlines 
and synclines of the region were produced, in addition to those local changes, such as the production of slaty cleavage in the fine-grained sediments of North Wales. In this immediate study it is important to realise that one broad and shallow synclinal fold included what is now Snowdon Mountain with its sedimentary and igneous rocks.

The last stage in the production of the mountain system as it now exists was, of course, the dissection and partial destruction of the uplifted and folded rocks. Much of the history of this stage is still obscure. During the vast time which has elapsed since the dawn of the

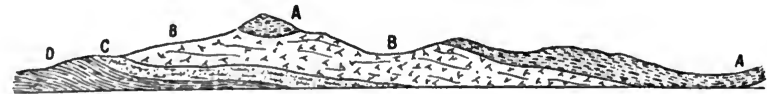

Fig. 13.-A Diagrammatic Section across the Rocks of SNOWDON to SHOW THAT IT IS A "Residual MOUNTAIN," RESUlting From the LONG-CONTINUED Denudation of A Series of Lower Palfozoic Rocks.

A. Beds of volcanic Ash, containing fossils. B. Acid lavas. C. Grit beds. D. Slates. The whole shown quite diagrammatically.

Carboniferous period, the region now under discussion has been subject to many vicissitudes. Possibly the whole of North Wales was covered by the widespread upper Cretaceous sea, but this is by no means universally accepted. It is sufficient to say that erosion and denudation, including the erosive work of ice in the glacial period, have removed vast quantities of material, and have cut deep into the original system. Snowdon itself remains a magnificent monument of these various stages, a residual mountain carved out of folded and faulted aqueous and igneous rocks belonging to ancient geological periods. A diagrammatic section of the rocks of Snowdon may render the structure and history clearer (see Fig. I3). 
A modern foreland range clearly offers the same kind of opportunity for the forces of erosion and denudation. The Jura of the Franco-Swiss border has been already mentioned as a type of a foreland range. As may be expected, it is already deeply dissected, and the traveller, by rail from Dôle, through Pontarlier to Lausanne, sees many a reminder that, in this younger range, mountains of denudation are being formed. The Jura range is in a much less advanced stage than the much worn Snowdon range.

We may include here a brief description of Escarpments, with some account of their further dissection. Escarpments are often produced by the denudation of stratified rocks which form one limb or slope of either a simple anticline or a syncline. Some of the most famous examples have been produced in folds of a broad and shallow character; and similar results may follow where horizontal strata, over a wide stretch of country, have received a distinct tilt in one definite direction. An escarpment may be defined as the boundary ridge or inland cliff of a formation, following the line of strike of the strata. It is clear that escarpments may exist in horizontal strata, but the more striking cases occur in formations where the beds have a low dip; in these cases there is a "scarp " edge or cliff facing in one direction and a gently inclined dip-slope in the direction at right-angles to the line of the escarpment. The reader may refer again to Figs. 3 and 4, showing the Jurassic limestone and chalk escarpments of middle England and the chalk escarpments of the North and South Downs.

The series of escarpments in eastern France is worth more than a passing mention, as the whole system illustrates remarkably well the denudation of a region consisting of alternations of hard and soft stratified rocks succeeding each other regularly, and having a low 
dip. The traveller from the Zabern Gate (north of the Vosges) to Paris passes over three well-defined escarpments, separated by belts of lowland formed of lessresistant strata.

(I) The Jurassic escarpment of the upper Meuse region and the Plateau de Langres.

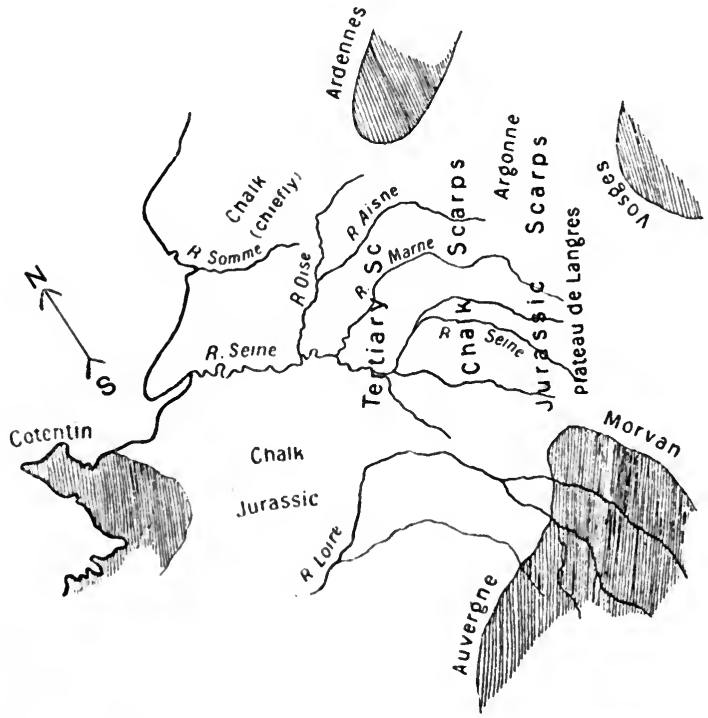

Fig. I4.-A Diagram-Map of the Paris Basin to SHOW ITS STRUCTURE.

The wider "basin" is surrounded by a number of blocks of much older

Rocks. The Tertiary (inner) "basin" is surrounded by Mesozoic

Rocks. (See the section, Fig. I 5 )

(2) The chalk escarpment of the Argonne and the Champagne.

(3) The Tertiary escarpment of the Soissonais and the Laonnais nearer to Paris. 
The rivers converging on Paris flow across these terrains as dip-slope streams. Beginning on the high ground of the Plateau de Langres they flow down its gentle slopes towards the north until the sharp cliffs of the chalk Argonne are reached. The rivers cut through this in defiles which have been famous in all the wars which have had Paris as their objective. After passing the chalk region, the converging rivers cut through the Tertiary limestones by such gaps as the famous one at Soissons. Thus the whole country has been dissected

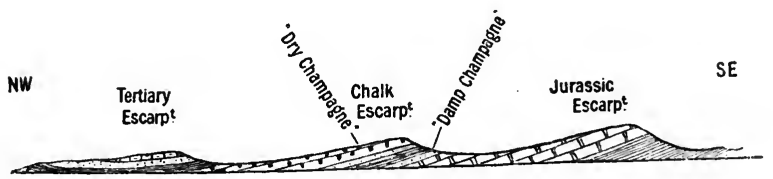

Fig. I5. - A Diagrammatic Section from N.W. to S.E., from the Paris Basin to the Region beyond the JURAssic Limestone Plateau, and through the Series of Famous ESCARPMENTS.

into a series of blocks having, on the whole, a gentle tilt towards the north-west. Paris is the natural focus of these lands.

The English North Downs are cut through by the Wey, Mole, and Medway; the Thames has cut through the chalk at Goring and Maidenhead, thus separating the Chilterns from the Berkshire Downs; and there are numerous old valleys through the Chilterns, dry valleys or "wind-gaps," through which the railway routes from the plains beyond the escarpments converge on London.

The plateau of the Swabian Jura, already referred to in this chapter, is a very gently sloping dip-slope, which has its escarpment or inland cliff edge facing Stuttgart, and the valley of the Neckar to the north-west. The dip-slope is towards Ulm and the upper Danube Valley. 
The Dissection of Alpine Mountain Ranges.-From the study of the dissection of Alpine forelands and some escarpments of Alpine origin we may pass naturally to the dissection of Alpine mountains themselves. The structure and origin of these complex mountain systems have been discussed in Chapter II. It only remains, in this chapter, to emphasise that most of the prominent mountain "peaks " of an Alpine system are true residual mountains. To repeat what was said in the earlier chapter, the forces of erosion are particularly active and dissection proceeds very rapidly. Hence the ranges are being cut up into the sierra-like form that is characteristic of these mountain systems. For example, the famous Aiguilles of the Mont Blanc group are obviously dissected pinnacles carved out of a mighty complex. When the great Alpine investigator, de Saussure, first saw the residual fragments of Mesozoic strata overlying the older rocks in the middle of the range, and realised that these newer rocks had once been continuous from one side of the mighty range to the other, he caught probably the first glimpse of the important part played by erosion and denudation in the production of a sierra-like folded mountain range.

The Production of a Peneplane.-If we imagine the denudation of a mountain range of any type to be continued sufficiently long, it is conceivable that the rivers may finally carry away the gradually dwindling mountains of denudation until a worn-down, fairly even surface is produced, with a gradual slope towards the sea. Such a final result was termed a Peneplain by Prof. W. M. Davis, of Harvard, U.S.A. Following a suggestion by Prof. J. W. Gregory we use the modified form, peneplane. Most of Finland has already reached that stage; another example is the surface of the Archæan land north of the St. Lawrence, the Laurentian " plateau " of 
some writers. As already mentioned, these particular peneplanes are final stages in the wearing-down of Alpine mountain ranges. It is a disputed question whether any subaerial peneplanes exist in Britain. The late Mr. Jukes-Browne even doubted their possibility, and considered any planes which had been produced as due to marine denudation.

The Highlands of Scotland.--This deeply dissected region consists of a plateau or an old peneplane cut up by a network of river-glens. There is nothing even remotely resembling a mountain chain. The abundant rain of this western edge of the continent has long supplied water for the countless rapid streams. These torrents flow through the deep and narrow glens, which may have been largely initiated by faulting, but which have been afterwards cut down by frost and rivers, and largely modified by ice-action during the glacial period. The immense folds and faults of the once great Alpine system are but faintly reflected in the present topography of this interesting region.

From the study of these various examples it is seen how Alpine-mountains, block-mountains, plateaux, mountains of accumulation, and the various sub-types of residual mountains are all intimately connected, and that the study of one form is bound up with that of others. For purposes of description we find it convenient to use the different names, and it is necessary, in our investigations, to consider somewhat extreme examples. When we apply the knowledge gained from the study of extreme types to the general study of the earth's surface, we are at once struck with the frequency with which mixed or transition types occur. To attempt rigidly to classify, and to place the different mountain-forms in sharply defined classes is contrary to the true spirit of science. 


\section{MOUNTAINS OF EROSION}

We will conclude this chapter by quoting a translation of the final paragraph from the late Prof. A. de Lapparent's Leçons de Géographie Physique, a work to which all students of Geography stand indebted. "We shall not carry further our rapid review of different types of mountains ; stating yet again that our object was not to establish a systematic classification, but rather to show how great was the variety of mountain types, and to indicate, whenever it was possible, the precise relations which must always exist between the geographical aspect and the geological conditions."

\section{BIBLIOGRAPHY}

(See the Bibliography to Chapters II. and III.)

(1) The Building of the British Isles. J. A. JukesBRowne. Stanford.

(2) Mountains: Their Origin, Growth, and Decay. J. GeIKIE. Gurney \& Jackson.

(3) Leçons de Géographie Physique. A. De Lapparent. Paris : Masson et Cie. 


\section{PLAINS}

Plains are areas with a fairly even surface and not very far above sea-level. A large and even surface raised considerably above sea-level and above the surrounding land is better treated as a plateau, though it is not always easy to decide whether a given region should be classed as a plain or plateau. Professor J. W. Gregory divides plains into four groups, two of denudation and two of deposition.

I. Peneplanes have been produced by the planing down of a country by subaerial erosion and river denudation. They have already been mentioned in the preceding chapter.

2. Plains of marine denudation have been formed by. the planing action of the surf attacking the coasts. By the cutting away of the cliffs during storms and at high tides, and the planing down of the belt of land between high and low tides into an even surface, the plain of marine denudation gradually extends back into the land.

3. Alluvial plains or plains of river deposit. The material is brought down from the higher parts of the river and is deposited when the water of the river begins to flow more slowly. The river gradually raises its bed, then breaks through its banks, and by continually changing its direction gradually makes a plain of deposited material. 
4. Coastal plains of deposition which occur on some of the continental margins. They are formed by the deposition of material in shallow water, and are submarine plains of deposit, which have been raised by subsequent uplift above the sea-level.

So many plains combine the characteristics of at least two of the above that we shall study them geographically rather than in genetic groups, at the same time making some mention of what is known concerning their mode of formation. The emphasis may, however, in this book, rightly be on the geographical rather than on the genetic point of view.

It is obvious that plains will not usually reveal so much of their underlying structure and origin as do other land-forms. The surface, and a very little depth below, is all that is exposed in many cases, except in river cuttings and in cliffs where the sea has cut into the rocks of the plain. We owe to occasional borings for water, salt, petroleum, and coal, much of our knowledge of the underlying rocks.

We shall discuss, in the first place, some of the greater plains of the world.

Plains of Eurasia - The Great European Plain.In this is included the great plain stretching across Europe from the low chalk " hills" and chalk cliffs of north-eastern France and the chalk hills of eastern England to the Arctic Ocean, the Urals, and the Caucasus, and including those submerged parts, the North Sea, most of the Baltic, and the White Sea. This plain is obviously of great importance in European geography and is worth somewhat extended study. From it we may readily illustrate some important general principles. Its western part, from the southwestern corner of the North Sea to the river Niemen, is mainly covered with Pleistocene deposits-river allu- 
vium, blown sands, glacial deposits, and peat. The wider eastern part, in Russia, is somewhat different, and consists of Cainozoic, Mesozoic, and Palæozoic rocks more or less covered by glacial beds, modified loess, or steppe sands and dust. The great plain is thus divided into western and eastern parts: the western we may call the Netherlands-Germanic plain ; the eastern part is the Russian plain. These greater divisions are capable of subdivision into lesser regions, each with its peculiar characteristics.

Flanders.-The famous plain of Flanders extends from near Cape Blanc Nez to the mouth of the Scheldt. The surface is sea-mud and sand and river alluvium, under which are clays and sands of Tertiary age. If the soil and subsoil are clayey, the land is extremely fertile, as, for example, the rich lands round Ypres; but if it is sandy it is not nearly so fertile, as may be seen in the comparatively barren land between Ghent and Bruges. The part of the plain between Bruges and Antwerp is a region with sand at the surface, but underneath is Tertiary clay, which keeps the land moist. Long-continued deep ploughing has brought up much of this clay subsoil and mixed it with the sand, making this region of Wass or Waes one of the fertile parts of Flanders. Along the coast from Dunkirk to the mouth of the Scheldt are sand dunes, where the contest between the sea and the land is still going on. Behind the sand dunes are lagoons, the "wadden" of the Flemish.

The Netherlands.-Eastward of the Scheldt estuary is a somewhat new type, the low country par excellence; it is chiefly the delta of the Rhine and Meuse. Here still continues the battle between rivers, winds, and sea, but to explain the present conformation we have also to call in the work of ice in the Pleistocene glacial epoch. Along the almost straight coast of North- 
Western Holland are sand dunes, which, near Haarlem, are three miles in width. These are the work of the wind, which drives them farther and farther inland, leaving the now unprotected coast to the ravages of the waves, but their landward progress has now been somewhat arrested by the planting of "bent-grass," the long roots of which bind the sand. Inside the dunes is the variable belt of wadden and farther inland the great area which was once marsh land. This lowland country reaches 25 miles in width, and extends along the banks of the distributaries of the Rhine. The Rhine mud has been deposited here through long ages, the rivers have raised their beds, and man has been compelled to confine them in well-defined channels by a magnificent system of dykes. The marshy meadows of this country have their surplus water pumped out, chiefly by windmills. Beyond the low marsh country, and farther inland, there is a quite different belt, the Campine of Belgium and the Geest of Holland. This is dry, sandy, infertile, and very thinly peopled. It is mainly covered with brown heath through which little mounds of sand protrude. It is over 300 feet in height in the east of the Veluwe or Bad Island of Holland. This interruption in the flat land is due to the melting ice of the great ice age. The borders of the Scandinavian ice reached this region, and the waters of the melting ice spread out here grit and pebbles from Scandinavia. The Rhine drainage was also bringing down its alluvium and throwing it against this northern drift. Thus was formed the mixture of enormous masses of stones, mud, and sand, found in the mounds of this infertile Campine and Geest.

The sea broke through the eastern cordon of dunes in the thirteenth century, and converted the old Lake Flavo into the immense Zuyder Zee, thus extending a re-conquest which the sea had been making for some 
time. Before the beginning of the glacial period the Rhine seems to have flowed northward over an old land and emptied itself somewhere between the Dogger Bank and Denmark. Since that time, and after the disappearance of the North Sea ice-sheet, the sea, aided by a general sinking of the land, has recovered much of its lost territory.

The plains of Flanders and the Netherlands are thus the work of winds, rivers, glaciers, and the sea, combined with sinking of the land since the glacial period.

From the Zuyder Zee to the Mouth of the Elbe.The types found in the Netherlands are, on the whole, continued to the Elbe region-dunes, wadden, marsh land, and heath; excepting that not much of the marsh land is below sea-level, and dykes are consequently not so numerous. The Campine type of country does not rise to so great an altitude as in the Veluwe of Holland : it is here a flat, barren land. The alluvium of the Ems and the Weser is spread over the lowlands. The line of dunes is on the Frisian Islands-long, low islands having their axes parallel to the coast; and the wadden are represented by the narrow belt of sea between the islands and the mainland. There are immense areas of peaty marshes inland, that of Oldenburg being perhaps the best known. The attacks of the sea, which formed the Zuyder Zee in the thirteenth century, also commenced the formation of the Dollart See and Jade Bay, and broke through the dunes forming the long line of islands.

From the Mouth of the Elbe to the Memel.-The coasts are now more cliff-like, and there is nothing quite like the wadden of the western parts of the great plain. The glacial deposits corresponding to the Campine and Geest now increase in importance because of increasing thickness. The most westerly and most important of these larger glacial moraines is 
the Lüneberg Heath, on the south-west side of the Elbe, at the very beginning of this modified country, where sands are mixed with immense erratics, many of which are of Scandinavian origin. This is the least fertile part of Germany, a land with a few scattered woods, and given over to the grazing of sheep.

Farther east is a distinctly morainic land, with numerous glacial lakes, the whole lying nearly parallel to the Baltic coast until the frontier of Russia is reached. The Masurian Lakes in East Prussia are the most easterly part of this region. Throughout the whole of this part of the plain the morainic " hills" are comparatively infertile, while the "valleys" are covered with river alluvium, and are the granary of this Prussian plain.

On the coast of the Baltic there has been some sinking of the land, and, on the other hand, the latter has been gaining on the sea by means of deposition. As an example of the sinking, the Isle of Rügen is known to have been once part of the mainland. The Frisches Haff, near Dantzig, was formed in $\mathrm{I}_{5}$ Io by an inrush of the sea, probably due to sinking of the land. In all probability the great Kurisches Haff was formed in the same way. The long spits of land, the nehrungs, are like sand dunes in their origin, and are formed by the westerly winds blowing the sand into long extended dunes.

From the cliffs of Calais to the eastern end of the Masurian Lakes almost the whole plain is covered with Pleistocene deposits, except where, in a very few localities, strata older than the Pleistocene are seen at the surface, these usually having been exposed by the rivers cutting through the newer strata and thus revealing the older beds. Very little is known of the strata below the Pleistocene beds. Borings have 
revealed Tertiary strata here and Mesozoic strata there, containing deposits of common salt and gypsum, while, in the Campine of Belgium, coal-beds have been reached.

The Russian Plain and its Divisions.-Almost the whole of European Russia is a great plain. From the Arctic Sea to the Black Sea, from Finland to the Caucasus, and from the Baltic to the Urals, the country is one vast expanse of relatively flat land. The so-called Valdai Hills rise to only IIoo feet above sealevel; they are the highest part of the very slightly elevated plain, a very trifling swelling in an almost illimitable stretch of flat country. In other respects the land is quite unique.

The geological map shows Mesozoic and Palæozoic rocks with a comparatively small area of marine and lacustrine Tertiary and Pleistocene strata in the southeast, with glacial deposits over a large part of Northern Russia.

Under the modern deposits is the Russian Platform of ancient rocks, one of the most stable parts of the earth's crust. Some parts are covered by sediments as old as the Silurian period, which are here horizontal, having been very little disturbed throughout the long periods which have seen folds and crust-block disturbances in other parts of the world. Long-continued erosion has planed down the land, and there have been few invasions of the sea over this vast territory. This, therefore, may be regarded as a great plain, levelled by erosion and denudation acting through very long geological ages.

There are three distinct sub-regions in the great plain outside Finland and the lake region generally, which has been mentioned already. These are: the Tundra, near the Arctic Sea, with the usual typical character of these marshy, icebound plains; next an 
immense zone covered by Pleistocene glacial deposits, now a land of marshes and of forests ; and, finally, the great grass region of the south and south-east, beyond the limits of former ice action; this extends to the Black Sea and the Caspian. These owe their different characteristics chiefly to differences in climate and, in a lesser degree, to differences in the nature of their superficial deposits.

The Tundra. - These icy plains extend from Archangel eastward over the low Timan range to the slopes of the Urals and southward to the zone of coniferous forests. The cold of winter is intense, and the atmosphere is very dry. Precipitation-chiefly snowfall-is consequently slight. The vegetation consists of lichens and mosses and a few heath plants, forest trees being absent, except in a few of the more favoured regions. The ground is perpetually frozen to a considerable depth, and most of the rivers are closed for more than half the year. The frozen deltas compel the rivers to overflow in the early summer, and then their alluvium is spread over the country to be frozen in with the general mass in the next winter. The Tundra plains are alluvial plains, with a surface largely covered with "icy marshes," the whole, in the case of Russia, apparently resting on a platform of Palæozoic and Mesozoic rocks.

The Middle Plain of Russia.-This is distinguished from the other elements of the Russian plain by the frequent presence of erratics and other glacial deposits, thus making it in some respects like the plain of North Germany. Glacial deposits reach a thickness of 650 feet in Poland. The topography is remarkably uniform; the rivers form marshy extensions, and the slopes of the slightly higher ground are covered with immense forests, coniferous in the northern part, and 
deciduous trees in the southern part. The remarkable character of the drainage is seen from the fact that the average fall of the Volga is I in I0,000; one of its tributaries receives some of its water from within Ioo miles of Lake Ladoga. The famous marshes of the Pripet are to some extent the counterpart of the marshy region of Masuria in East Prussia. This once glaciated plain has a substratum of Palæozoic and Mesozoic rocks, which are brought to light in the deeper cuttings of the rivers. It is a second part of the plain of the Russian platform.

The Prairie-Steppe Region of the South and East. -This region outside the glaciated zone is divisible into two sub-regions, depending mainly upon climatic differences; these are the country of the Tchernozoum or the Black Earth region, and the steppe land of the south and south-east. The surface deposits of the Black Earth zone are loess-like loam, probably formed in part like the loess of China, and partly by sands and muds brought by the rivers from the glaciated region. This mixture of sands and clays formed a suitable terrain in which herbaceous plants grew rapidly, and the intermingling of the decayed vegetation with the alluvial, glacial, and æolian deposits has produced the fertile soil of this well-known region.

The Black Earth zone extends from the southwestern parts of the Russian platform, from what Dr. Mill calls "Carpathia" to the Urals, the northern boundary being roughly from about lat. $54^{\circ}$ in the southwest to lat. $57^{\circ}$ in the north-east. The southern boundary is not so well defined, but dovetails into the steppe. The whole area is at least two and a half times the size of Great Britain. It is distinguished by the remarkable fertility of its soil ; lucerne, wheat, beetroot, and, in the extreme south, maize doing remarkably 
well. The grass prairies and steppes are south and south-east of the Black Earth region. The rainfall diminishes towards the south-east until in the lowlands adjoining the Caspian there is a fall of about six inches a year, compared with sixteen inches at Odessa, and twenty-one inches at Kiev.

But the difference between the Black Earth region and the steppe is not simply one of present differences of rainfall. In recent geological times a sea occupied the region east of the Don; the soil, therefore, is too salty for rich growth, and this, combined with the low rainfall, produces the true steppes of the Don and the lower Volga. The sea extended from the Black Sea through the Manych depression to the Caspian and northwards, where it probably had a connection with the Arctic Sea through the Ob Valley.

The great Russian plain is thus an old platform of long - continued denudation, lowered by earth - movements, and covered by glâcial, river, sea, and wind-borne deposits, in places mingled with much vegetable debris, the whole now having differences in climate sufficient to divide it into well-defined regions.

The Plains of Western Siberia.-From the steeper eastern slopes of the Urals to the Yenisei there is a vast plain similar to that of European Russia. The northern part is an immense area of tundra which stretches without interruption from the estuary of the $\mathrm{Ob}$ to that of the Yenisei. Eight long winter months seal up the land. Then, with the coming of spring, the rivers, flowing from the south, overflow the ice-locked northern plains, and, as in Europe, only on a greater scale, river alluvium is spread over the land to be frozen in by the next long winter's frost. South of this is the great forest zone, which, north of 'Tobolsk, is a land of marshes and thick forests. This was not 
glaciated like the middle region of European Russia, but is mainly covered with Pleistocene fresh-water deposits. In the south is a black-earth region, where wind-borne sand and loam, mixed with vegetable debris, have accumulated since the Miocene period, when the arm of the great sea left it.

This great West Siberian plain is one of the most level plains known. For over Iooo miles in each direction there is no part more than 600 feet above sea-level. The basis of this vast plain had been levelled by denudation during the long eras from the Carboniferous period to the beginning of the Tertiary. The Tertiary and Pleistocene seas and lakes have filled up some of the inequalities, and the rivers have continued the levelling process, producing the apparently illimitable expanse of plain which the Trans-Siberian Railway crosses after leaving the Urals.

The Aralo-Caspian Depression.-This is the greatest region of its kind on the earth's surface ; a good deal of it is below the level of the surface of the nearest ocean. It was formerly occupied by the sea which extended westward through the Manych depression to the Black Sea and northward to the Ob basin and the Arctic. The region north of the Aral Sea is now dotted over with lakes without outlet. The Caspian formerly had a great extension from east to west; its north to south extension is now much the greater. The Aral was once much larger than it is now, and probably extended westward along the Sarakamych depression, which is even lower than the Caspian Sea. This depression is now occupied by brackish lakes. The whole region is probably one of gradually diminishing rainfall, and the steppes and deserts are of comparatively modern origin. The rivers which come from the great ThianShan, Hindoo Koosh, and Khorassan ranges bring down 
immense quantities of glacial debris and river muds and sands, but as many of these rivers are lost in the desert, and only the Syr Daria and Amu Daria reach the Sea of Aral through courses which are continually changing, the amount of drift being spread over the plain must be very considerable. Some of this drift must have passed through three phases-glaciation, then river transportation, and finally it is blown by the winds during the sand-storms so frequent in the region. The names of the "sand-deserts" are significant, the Kara Kum or Black Sands in the northern part, the Kisil Kum or Red Sands between the two great rivers, and the Ak Kum or White Sands north of the great Thian Shan range. The Turkoman Desert lies between the southern end of the Aral Sea and the Caspian; the extreme north of the depression, where desert passes into steppe, is the famous Kirghiz Steppe.

In a measure the four great plains-North German Lowlands, Russia, Western Siberia, and Aralo-Caspianare part of one great earth region, and have much in common. They are vast sunken parts of the earth's crust, where erosion and denudation have been at work for long periods of geological time ; afterwards, in later Tertiary and Pleistocene times, that is, in quite recent geological periods, they have been covered in varying degree with deposits of rivers, seas, glaciers, and wind, these deposits being often intermingled and overlapping, and producing special conditions in com paratively limited regions. These great plains are often spoken of as the Great Eurasian Plain by geographers, and there is justification for this in the fact that the plain is continuous from the Wash to the Yenisei, from the White Sea to the southern desert of Turkestan, with only the very minor break of the low Urals and their 
branch, the Timan range, and the small Ust Urt plateau between the Aral and the Caspian Seas.

The Great Plain of North America. - The build of North America is comparatively simple. It consists of four chief elements: (a) Long lines of younger fold-mountains in the west, with the crust-blocks between them: (b) the older and lower Atlantic mountains in the east; (c) between these the great plains stretching from the Arctic Ocean to the midland sea in the south; and $(d)$ the Atlantic coastal plain. The great medial plain, or series of plains, illustrates some general principles very well, and the study of them may well follow that of the great plains of the old world. We may consider five divisions, though here, as always, they often grade into each other - the Gulf Plain in the south, the prairies in the middle of the continent, the great plains or great plateaux reaching to the foot of the Rocky Mountains, the sub-Arctic Forest Plains, and the Arctic Tundra in the far north.

Considering these plains as a whole, it may be said that between the older Highlands of the east and the newer Highlands of the west there seems to be a very great and shallow syncline, in which Palæozoic and Mesozoic rocks lie fairly horizontally. The far north -round Hudson Bay-is an Archæan land and, in many respects, is somewhat like Finland; the far south, along the border of the Gulf of Mexico, and some distance up the valley of the Mississippi, is a region of Pleistocene and Tertiary deposits. The region round the great lakes, though it lies between the north-eastern prairies and the low plains round Hudson Bay, and though it has been named the Plain of the Great Lakes, is not so much a plain as a dissected Archæan plateau.

This vast continental basin embraces about threefifths of North America ; it contains most of the drainage 
areas of the Mississippi-Missouri system, the rivers which drain to Hudson Bay and the great Mackenzie system of the far north. It is possible to pass from the Arctic Sea to the Gulf of Mexico without rising to rooo feet, though much of the continental basin reaches far above that level. Still there is remarkable general evenness of surface and of structure, the only exceptions to the real plain character being the Lake Plateau, the Black Hills of Dakota, and the Ozark Mountains between the Kansas and Arkansas Rivers.

The various sections of the great basin have characteristics dependent upon the local nature of the deposits and upon climate, many of the considerations being the same as in the case of the Eurasian plains. The Gulf Plains have a basis of Tertiary strata, for the sea invaded the region as far as St. Louis in Pliocene times. A Pleistocene marine invasion has also spread its sediments over large parts of the plain. Much of the surface of the lower Mississippi basin is mainly covered by the alluvium of the great river, which frequently overflows its banks. This river and its tributaries have deposited immense quantities of silt, and have changed their courses very frequently, hence there are plenty of cut-off lakes and marshes, in which vegetation grows to intermingle its organic residue with the alluvium of the plains. Sir Charles Lyell made the lower basin of the Mississippi known for all time by his clear description of the curves of the river, its crescentic cut-off portions (now called Ox-bows), its raised banks or levees, the swamps adjoining the river, and the structure of the great.delta.

The Gulf Plains are the home of the southern pine, which forms the basis of an important industry. Many other timber trees are also found there, and, before the advent of man, large parts of it were clothed with such a 
dense forest of trees and of creepers as to be practically impenetrable. It is now a region well adapted for the cultivation of maize, cotton, rice, and the sugar-cane.

The Prairie Plains.-These stretch from Texas to the Great Lakes and northwards through Minnesota into Canada. For Iooo miles one may travel northwards over these gently rolling fertile lands, which are 800 miles in width in the central part, and cover in all nearly half a million square miles, or four times the area of the British Isles. Throughout almost all their vast extent the underlying rocks are horizontal sandstones and limestones. The deposits of an ancient sea have been raised with slight disturbance into the almost flat prairie, the local variations of which are largely due to variable rock erosion, and especially to the work of streams which have cut deep valleys in the easily eroded strata. A new factor was introduced into the character of the prairie north of the Ohio River during the glacial period, for glacial ice, with its underflow of sub-glacial streams and its outflow of siltladen water at the ice margin, has spread over the prairie deposits of glacial clay, sand, and gravel, and left huge morainic mounds and myriads of erratics here and there. The prairies are thus somewhat like middle Russia, and the subsoil of the prairie south of the ice margin is often much like the Tchernozoum of Russia, black and wonderfully fertile. The North American prairie must be traced far into Canada, however, before we find the real counterpart of the mid-Russian plain, where the sub-Arctic forest plain, with its primeval forest and its marsh, forms another division of the Great.Continental Plain.

The Great Prairie Plains are now the lands of cotton in the south, maize in the centre, and of wheat in the north. The prairie region of Minnesota, Dakota, and 
Manitoba to-day forms one of the great wheat areas of the world.

The Great Plateaux.-These have been mentioned already (Chapter III.). It may be added here that they extend from the prairies of the central continental basin in a vast expanse to the foot of the Rocky Mountains. They gradually rise from east to west until they reach nearly 6000 feet, but the ascent is so gradual that the aspect is one of almost unbroken monotony. Too dry for much timber, and also too dry for maize and wheat, these great plateaux are the great stock-rearing regions of the continent. These plains are largely occupied by Cretaceous deposits, though there are also large areas of Tertiary strata; through these the eastward flowing rivers have cut their way, in some cases in deep channels, in others in wide valleys. The most deeply dissected part is the plain of Texas where the rivers have cut cañon-like gorges in the Cretaceous grits and Tertiary sandstones of this dry region. The "Bad Lands" of Dakota already described occur in the northern portion of the United States plateau. The Great Plateaux extend into Canada, where the rivers flow hundreds of feet below the plateau surface, and hence are almost useless for irrigation purposes. This, therefore, is the stockraising region, though an extension of wheat-growing is now in rapid progress.

The Sub-Arctic Forest Plain. -This spreads almost across the whole northern continental basin, from the Laurentian plateau to the base of the Rocky Mountains. The change in condition from prairie and dry plateau to sub-Arctic forest comes gradually, and is chiefly due to less evaporation and to the longer persistence of water in the soil. The influence of former ice-sheets is seen in the numerous swamps and lakes, and the whole 
region reminds one of the glaciated forest region of mid-Russia.

The Tundra.-In North America, as in Russia, the tundra succeeds the forest region. It is a vast frozen morass, the vegetation of which is chiefly mosses and lichens, and in the short summer a luxuriant carpet of flowering plants springs up as by magic. As in Siberia and European Russia the subsoil is permanently frozen to a considerable extent. The rivers thaw in their upper reaches before the ice of the deltas and estuaries has melted; and there is then, as in Russia, overflowing and mingling of alluvium with the black peaty soil, the whole to be frozen in as the next long winter sets in.

The Great Continental Plains are thus a vast sunken area, partly covered with Palæozoic, Mesozoic, and Tertiary sediments, which are on the whole remarkably horizontal. Newer deposits by sea, rivers, wind, ice, and vegetable growth have modified the fundamental character of the region just as in Russia. The north to south extension, and the diminution of the rainfall towards the west until the Rocky Mountains are reached, allow the influence of climate to reveal itself to a very marked degree.

The Plains of South America.-There is considerable similarity between the structure of North America and South America. The southern continent, like the northern, has a great series of Pacific mountains in the west (younger folded mountains), and a series of older highlands in the east, and between these a series of vast plains. The South American continental plains may be divided into three regions: (I) The plain of the Orinoco ; (2) the vast plains of the Amazon; (3) the La Plata plains, including the Pampas.

The plain of the Orinoco is filled with sands, gravels, etc., recent river deposits which rest on Tertiary marine 
strata. The plains are called Llanos, grassy plains sloping gradually towards the sea, and dissected into mesas by the tributaries of the Orinoco. Some parts of the plains are almost desert, but forest growths of tropical lowland type encroach on these grassy plains in the wetter regions.

The vast Amazonian Plain rests in a wide syncline, filled with Mesozoic and Tertiary deposits. The rainfall is very great, and the river brings down heavy quantities of sediment. The basin has thus been filled with rich alluvium on which grows the luxuriant tropical vegetation, fed by the abundant rains. The great river flows in wide-branching channels through its own deposits, in a plain which reaches to the very foot of the Andes. The extent, and the level character of the plain, are shown by the position of Iquitos, 300 feet above sea-level, and 1400 miles from the mouth of the mighty river.

The watershed between the Amazon basin and that of the La Plata is a very low one, comparable to that separating the Mississippi basin from the Hudson Bay drainage. Immediately south of the watershed is the Gran Chaco, an immense plain where marshes and cutoff rivers abound. This plain is divided into northern, central, and southern parts, each with its own peculiarities of vegetation and drainage. The tropical forest ceases here, and the steppe of the warm temperate region begins. In the great $\mathrm{La}$ Plata depression are river deposits, and a loam akin to loess, overlying Tertiary beds which in their turn seem to lie on a foundation of Archæan rocks. The Pampas, south of the Gran Chaco, are immense plains with innumerable salt lakes, and rivers which often lose themselves in marshes or lagoons. Some of the deposits of the plain were probably formed in a time of greater rainfall by rivers which have now lost much of their power. 
The Australian Plains.-These are very similar in general character to the drier prairies of North America and the Pampas of South America, and need not be further discussed here.

\section{Some Intermont Plains}

The Hungarian Plain.-This plain lies within the curve of the folded Carpathians, and against the somewhat abrupt termination of the expanded eastern Alps. It is clearly a depressed area, with a series of fracture-lines bounding its margins. The extent to which sinking has taken place has been shown by a boring near the Danube which passed through 3000 feet of newer strata before arriving at the floor of older rocks on which the deposits of the plain rest. At the beginning of the Miocene period there was a sea covering much of this area. The sea was gradually filled up with sediments until there were left only brackish lakes, becoming more and more salty. Salt deposits of Tertiary age are the result of this disappearing sea. Finally steppe conditions resulted, and deposits of loess alternated with river alluvium from the encircling mountains and the distant Alps.

There are two plains, the lesser Alföld or basin of Vienna and the greater Alföld or Hungarian Plain. The former contains immense deposits of gravels and sands brought down by the Danube, by the Raab from the Alps, and by the Carpathian Rivers. The greater plain, the Alföld proper, has Tertiary rocks underlying 600 feet or so of Pleistocene river alluvium and semidesert loess. In some parts, especially between the rivers Danube and Theiss, there are shifting sand deposits.

The continued accumulation of sediment is seen in the growing dykes which are necessary to contain the Theiss 
below Szegedin. The great Carpathian river has a fall less than that of the Danube, hence, when the latter rises considerably, as the result of the melting of the Alpine snows, the Theiss is dammed back. This may be accentuated by the flooding at the same time of its two great lateral tributaries, the Samosh and the Korosh, which bring down the flood waters and alluvium of the Carpathians and Transylvanian Alps. These great tributaries with their rapid flow and their enormous bulk of sediment are pushing the Theiss westward towards the Danube. The river has thus been driven westward for at least 60 miles within the recent period.

The typical Hungarian plains or pusstas have much of the true continental character of the Russian steppe. More of the plain is being reclaimed for settled agriculture, and fields of maize, wheat, and beet are increasing in number at the expense of areas formerly given over to sheep, cattle, and the half-wild horses of the plain.

The Plain of Lombardy. - This is part of the sunken Adriatic Gulf, filled up by sediments derived from the erosion of the Alps. In the Pliocene period it was still occupied by the sea, and marine deposits of that period are found at the foot of the Alps. Glaciers and Alpine torrents have combined to fill up the shallowing sea, and have succeeded so well that a boring at Modena, 6 miles south of the Po, passed through 600 feet of Alpine deposits. The work of erosion and transportation still goes on, and the allivial deposits are rapidly encroaching on the Adriatic Sea. Within historic times the deltas of the Po and Adige have added most of the lagoon-bordered land between Ravenna and the Gulf of Trieste. The alluvial plain of the Po is thus similar to that of the Danube-Theiss; the former being of later origin however. They are alike in being 
sunken areas filled in partly with marine sediments, covered with vast deposits of river-borne material, coming from mountains where erosion is proceeding at a rapid rate.

Alluvial Plains between Fold-Mountains and CrustBlocks.-In many parts of the world, between Alpine mountains and resistant crust-blocks of older rocks, there are sunken areas which are now more or less filled with sediments derived mainly from the great mountain chains, partly from the worn edges of the crustblocks. Only a few examples of these obvious alluvial plains need be mentioned, but it will readily be seen that they include some of the most important and most fertile parts of the earth's surface. (a) The Plain of Andalusia, or the Valley of the Guadalquivir, in Spain, lies between the folded Sierra Nevada and the Sierra Morena, which is the dissected edge of the Meseta-this is a plain which, when properly irrigated, is of great fertility, though some portions of it are marshy and malarial; (b) the Valley of the Rhone between the lofty Alps and the Cevennes is very similar, but quite narrow, with a mountain extension from the Auvergne plateau coming to the right bank of the river at Valence and for some distance south of that town; (c) the Great Plain or Valley of Mesopotamia, watered by the Euphrates and Tigris, seems to lie similarly between the younger line of the Zagros Mountains and the old block of Arabia. The two great rivers formerly entered the Persian Gulf separately, but they now join and form the Chatt-el-Arab, which is pushing its sediment into the Persian Gulf just as the Po-Adige is filling up the Adriatic. At the beginning of the last century the delta had extended itself 2 miles in about forty years. Within historic times it has encroached on the gulf about 600 miles. (d) The Indo-Gangetic plain is 
one of the most important plains in the world; in parts it is very thickly peopled, and is inhabited by at least 200 millions of people. To the north of the Deccan platform lies the depression which is complementary to the great Himalayan fold. The two great river systems, the Indus and the Ganges, are continually bringing down enormous quantities of sediment. Borings in the delta of the combined Ganges and Brahmaputra show river deposits to a depth of 500 feet, and indicate the immense amount of deposition which has taken place in the trough between the young fold-mountains and the old resistant block of Peninsular India.

A Typical Coastal Plain-The North America Atlantic Coastal Plain.-In eastern North America there is a remarkable coastal plain extending from New York to the Gulf of Mexico, and this may be briefly studied as a typical example. The roo-feet contour line is approximately the landward boundary of this plain, and the numerous rivers from the Appalachians descend in waterfalls at this level to flow as navigable rivers across the lowland. Many of the rivers form broad tidal estuaries. At the fall-line limit there occurs a series of well-known towns-Trenton, Philadelphia, Baltimore, Washington, Richmond, etc. The plain continues beyond the shore line as a shelving coast for some distance outwards, until a sudden drop is reached where the "continental shelf" ends and the real Atlantic Ocean begins. The submerged continental shelf and the coastal plains may be regarded as parts of the same land-form.

The inland limit of the coastal plain is a sharp boundary line between older rocks and strata of late Mesozoic and Cainozoic age, which form the basis of the plain. Resting on these are alluvial deposits brought by the numerous rivers. Under the shallow water of the 
continental shelf are deposits of continental origin, sand and clays chiefly. Clays occur in plenty in the submerged estuaries which are continuations out to sea of those on land. The whole structure tells of a sunken coast with drowned river-valleys now forming tidal estuaries.

The plain is mainly constructive in origin - that is, it is formed of deposits, marine and alluvial, according to circumstances, but there is little doubt that tidal erosion has also played a part in cutting back cliffs and planing down the land, and so to a smaller degree the coastal plain is a plain of marine denudation:

\section{BIBLIOGRAPHY}

Descriptions of the great plains of the world may be read in the larger geographical text-books, and in various books dealing with the geography of special regions. The following will be found useful :

"The Regions of the World" Series, edited by H. J. MaCKINDER, published by Frowde. Central Europe, by JOSEPH PARTSCH, contains descriptions of the Netherlands-Germanic Plain, and the Danubian plains; The Nearer East, by D. G. HoGARTH, may be consulted for the plains of Mesopotamia and Egypt; India, by Colonel Sir T. HoLDICH, for the plains of that country; The Farther East, by A. LiTTLE, for the plains of China ; and North America, by I. C. RUSSELL, for both the Atlantic Coastal Plain and the great plains of the interior: of the continent.

The Continent of Europe. L. W. LyDE. Macmillan \& Co. May be consulted for all the European plains.

The International Geography. Edited by H. R. MiLL. Macmillan \& Co. Contains descriptions of almost all the plains in the world.

Compendium of Geography and Travel. STANFORD. I 3 volumes. This large work contains the fullest description of the countries of the world that is readily accessible to English readers, 


\section{PLAINS}

The above books deal with the other land-forms, of course, and may be used in connection with the subjects of many of the other chapters.

See also Earth Features and their Meaning, HoBBS; College Physiography, TARR AND MARTIN ; Geography: Structural, Physical, and Comparative, GREGORY; and the Bibliography of Chapters II. and III. 


\section{VALLEYS AND BASINS}

VALLEyS are of great variety of form and origin, but, broadly speaking, it is convenient to divide them into two great classes:-Tectonic Valleys, which are immediately due to movements in the earth's crust, and Erosion Valleys. It is quite possible, indeed it is highly probable, that many valleys which are regarded as valleys of erosion are partly tectonic. In this respect valleys are quite like other earth-features, difficult to classify rigidly.

\section{Tectonic Valleys}

These may be divided into two sub-classes: Valleys in downfolds of rocks, or Synclinal Valleys; and (b) Fault and Rift Valleys.

Synclinal or Downfold Valleys.-It has already been stated that the earth's crust has been thrown, in many regions, into a series of folds, trough-folds or synclines and arch-folds or anticlines, and examples of these have been mentioned. It is obvious that in a series of such folds the synclines must tend to form valleys, and many such valleys are seen in different parts of the world.

The syncline of the Cretaceous and Tertiary rocks of the London basin was mentioned in Chapter II. This basin is often described as the lower Thames Valley, though perhaps, in ordinary language, the two 
names do not connote quite the same thing; the basin is probably usually considered to be more extensive than the valley, and to include it.

There are many such synclinal basins, but it is not always the case that a river runs for a considerable distance along the "axis" of the downfold as the Thames does from Reading to the sea. The following are British instances where the rivers do flow axially: The Vale of Pickering is a very shallow basin, extending from east to west between the Howardian Hills and the Tabular Hills of the North York moors. The Lancashire Calder, from Colne to the Whalley Gap, has the main stream flowing along the syncline of the Burnley coal-field. The valley of the Frome in Somersetshire is another example. The valley or basin of the Ebro (or the Aragon depression) in Spain is a synclinal basin of Mesozoic and Tertiary strata. The depression is bordered on the south-east by the Catalonian Mountains, through which the Ebro has cut its way in a fine transverse gorge.

A longitudinal valley-basin extends between the two chains of the Atlas, which is apparently of the same type as the Upper Rhone and Vorder Rhine valleys between the middle and northern Alps. This long valley system contains Jurassic and Cretaceous rocks thrown into folds, and may be described as a synclinal valley. The lower parts of this trough contain salt-lakes, known as Shotts; the region is one of very low rainfall: Some parts of the valley contain thick deposits of Pleistocene age, derived from the weathering of the high mountains of Alpine type during an age when rainfall was more abundant than it is to-day.

There is a somewhat similar longitudinal valley in North America-a long, narrow trough-which is 
probably very similar in structure to the valley of the Shotts. This occurs between the Pacific Coast ranges and those of the Sierra Nevada and Cascades. The valley of San Joachim, the Sacramento valley, and Puget Sound are probably all parts of this downfold valley. A good deal of faulting has accompanied the folding, and there is plenty of evidence that this portion of the earth's crust has not yet reached anything like a stable condition.

The Sacramento valley has been largely filled with fertile alluvium, and it forms a veritable garden of the west. The San Joachim and Sacramento Rivers unite and flow into the Pacific through the transverse Golden Gate at San Francisco, where the coast range is cut at right angles. Somewhat more to the south the salt lake Tulare, in a limited region of internal drainage, reproduces some of the features of the Shotts of the Alfa valley of North Africa.

The folding of great Alpine systems often produces longitudinal valleys extending along the strike or trend of the strata. Professor Bonney long ago pointed out that the valley of the Rhone above Martigny was originally a synclinal fold of softer rocks extending lengthways between the Bernese Oberland and the Pennine Alps. The valley of the Vorder Rhine from Chur up to its end at the foot of the Oberalp Pass is similar in structure to that of the Rhone, and needs only this brief mention here.

A magnificent series of folded valleys occurs at the eastern end of the Gangetic Plain of India, where the Yang-tse, Mekong, Salwen, and Irrawadi run in mighty longitudinal folds between the great parallel mountains. Similarly the Drave and Save flow in the synclinal basins formed by the opening out of the eastern Alps.

Some of the rivers of the Jura run for long distances 
as longitudinal rivers, along the axes of synclinal folds formed in that Alpine foreland. It is said that there are twenty such parallel folds in the Jura, and the rivers which run along their troughs break through in transverse cluses, which are, in the main, the routes through from the Rhone-Saone to the Swiss plateau.

Prof. J. B. Jukes pointed out long ago that the rocks of Southern Ireland have been thrown into a series of parallel folds whose axes run east and west. The longitudinal stretches of the Bandon, Lee, and Blackwater run along these folds, and then turn off in transverse gorges at right angles to their earlier courses. Jukes's paper, written in I862, was probably the first systematic survey of a series of river-valleys from the genetic point of view.

It will appear from a consideration of the examples discussed above that the terms valley and basin have not always a very definite connotation. We speak of the "Vale of Pickering," but seldom of the valley; it forms a very shallow valley or basin. In North-East Lancashire, "Burnley Basin" or "Calder Basin" is used quite as frequently as Calder Valley, and yet, as in the case of the London and the Thames, the valley and the basin are not quite the same.

Synclinal basins on a large scale-that is, where there is a shallow downfold in which newer deposits have been accumulated-are quite numerous; the Paris basin is a well-known example.

The Mississippi basin is probably an enormous shallow syncline stretching from the western slopes of the Appalachians to the eastern slopes of the Rocky Mountains. There are many other examples of tectonic basins in different parts of the world.

Fault Valleys and Rift Valleys or Trough Valleys. -This part of the subject also may be best illustrated 
by examples. The Vale of Eden may be taken as the first type. The great Pennine Fault was mentioned in Chapter IV. It forms a magnificent scarp from the edge of which the observer looks westward over the fertile Vale of Eden, with its patchwork of cornfields and meadowland, and numerous plots where the red soil of newly ploughed fields shows in striking contrast. Farther west rise the hills of the dissected dome of the Lake District. The rocks of the Vale of Eden are Triassic and Permian (together called the New Red Sandstone), and are newer than the rocks forming the

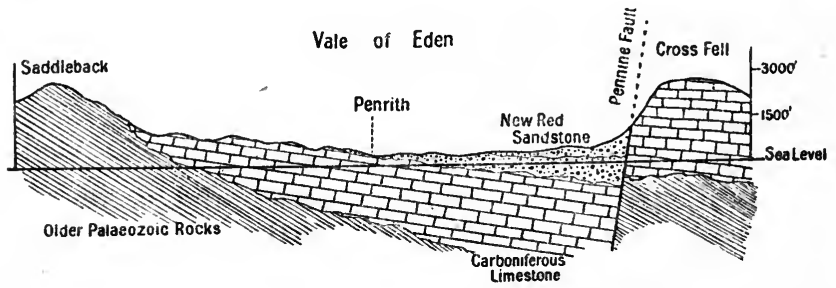

Fig. i6.-A Diagrammatic Horizontal Section from Saddleback to Cross Fell across the Vale of Eden, to show tile Relation of tie Rocks to the Pennine Fault.

Cross Fell plateau, which are Carboniferous. The same Carboniferous rocks are seen on the eastern edge of the Lake District forming the partial border already mentioned (see Geological map, Fig. 10). These dip under the New Red Sandstone marls and sandstones of the Vale of Eden. The general structure and relation to the fault is best seen by a section (Fig. I6).

Thus the Vale of Eden is a fault valley or wedgeshaped basin, and the sharply contrasted geographical regions - the Cross Fell plateau, the' vale itself, and the Lake District dome-are obviously due to the relation of the different rocks to the great Pennine Fault already mentioned. 
The Vale of Andalusia or Guadalquivir Valley is very similar in structure. It lies between the Alpine Mountains-the Sierra Nevada, and the faulted edge of the Meseta, known as the Sierra Morena. This valley has already been described as an alluvial plain, thus forming another example of how land-forms grade into each other insensibly.

A very fine example of a valley due to fracture, but not a rift valley, as generally understood, is the Great Glen of Scotland. This magnificent natural trench extends in a perfectly straight line for roo miles, right across the country from the Firth of Lorne to the Moray Firth. The bottom of this glen is never more than Ioo feet above sea-level, but the deepest part is nearly 800 feet below the surface level of the sea. In the deeper parts of this straight trench lie the lakes Lochy, Oich, and Ness, the latter nearly 20 miles long and less than I mile in width. Many of the other Scottish glens, some of them forming sea-lochs and some containing long, ribbon lakes, lie in fracturetrenches, having the same general direction. An inspection of a good orographical map shows a whole series of valleys strictly parallel to Glen More; another series is almost at right angles and also contains fiords and inland lakes. The Scottish plateau was evidently shattered by a double series of interlacing fractures, probably at the time when the North Atlantic was formed and Scotland was separated from Scandinavia. The fracture-trenches are the famous Scottish glens. Some of these glens may be simply deep river-worn valleys, but it is almost inconceivable that so many of them should lie in definite directions, the same directions as that of known fractures, unless they are associated with faults which follow the same direction but are not apparent at the surface. The fiords of the 
western coast of Scotland are probably drowned valleys of this type (see Chapter VIII.).

The Rift Valley of the Rhine was discussed in Chapter II. This is an admirable example of a valley formed by a pair of roughly parallel faults letting down the region between the two horsts. The bottom of the valley is a plain of considerable extent, 200 miles from south to north, and roughly 20 miles in width.

A most interesting rift valley, or linear series of rift valleys, extends from the north of the Dead Sea to the Zambesi region in Africa, and includes the Gulf of Akaba, the Red Sea, and the basins of Lake Rudolph and Lake Nyassa. This line of depressions extends for 3000 miles, and marks one of the most distinctly fractured parts of the earth's crust. It ends off abruptly against the Taurus range of Asia Minor. The Lake of Tiberias, the Valley of the Jordan, the Wadi-el-Arabah, the Gulf of Akaba are obvious parts of it in the north. Lake Tanganyika occupies a similar linear depression, which appears to be related to the series of fractures mentioned above.

The basin of Utah, Nevada, and Oregon is another example of a sunken portion of the crust due to a series of fractures. In this region evaporation keeps pace with the small rainfall, and many of the various lakes which exist in the hollow have no outlet, and are therefore salty.

Lake Baikal in Central Asia occupies a fault basin. Its surface is 1560 feet above sea-level, but it is so deep that its bottom is more than 3000 feet below sealevel. It is the deepest of all the continental depressions. Its very steep walls are probably fault scarps, formed in comparatively recent times, and the existence of volcanic craters in the neighbourhood, and the 
frequency of earthquakes, show that the crust is still in an unstable condition.

Spencer Gulf in South Australia is yet another example of a valley due to subsidence between two lines of faults; it is a "rift-valley" similar to that of the Rhine. St. Vincent Gulf is probably a similar subsided region.

The Central Valley of Scotland-generally known as the Lowlands-is another well-known example of a rift valley, of which the width is relatively great. A great north-western boundary fault divides Strathmore from the Highlands, and a nearly parallel series of faults separates the Southern Uplands from the Midland Valley. The northern fracture-line stretches from near Aberdeen to the Isle of Arran; the southern series of fractures from near St. Abb's Head to Ballantrae. The southern system of faults is not so well defined as the Highland boundary fault. Between these two parallel fault-systems the Palæozoic rocks of the Midland Trough were let down, and probably in consequence of the subsidence, masses of volcanic rocks were extruded at various points along a direction roughly parallel to the general north-east and south-west trend of the faults. These volcanic rocks have resisted denudation better than the Old Red Sandstone and the Carboniferous sediments of the Lowlands, and there are four groups of hills separated by the great rivers which cross the "Rift Valley." The Sidlaws, Ochils, Campsie Fells, and Renfrew Heights are the hills referred to ; they extend serially along a line which is roughly parallel to the great boundary fault.

The Midland Trough or Rift Valley is thus an example of a tectonic depression of very great geographical importance because the majority of the Scottish people 
are located on its fertile lowlands or its industrial regions. It is variously described as a valley, a basin, and a trough. There is something to be said in favour of the use of each of these ; perhaps least of all for the name "valley." It is clear, however, that we have here another illustration of the difficulty of using a definite series of names, each with a limited meaning. The difficulty is inherent, because these different sub-types of land-forms grade into each other quite insensibly. It seems inadvisable to insist on a rigid connotation in this as in other departments of descriptive natural science.

There are many similar rift troughs or valleys in different parts of the world, An interesting modification is found in Nevada where cañon-like valleys occur, which are obviously due to subsidence. These were at first mistaken for cañons of the Colorado type, that is, cañons due to erosion by rivers acting on approximately horizontal strata in a dry region.

\section{VALlEYS OF EROSION}

Many valleys of this type were necessarily mentioned in Chapter IV., in discussing the dissection of elevated land-forms, and some of the different subtypes were foreshadowed. These forms illustrate Prof. Davis's principle that all land-forms are functions of structure, process, and stage. That is, their present condition depends firstly upon the nature and relationship of the rocks out of which they were formed; secondly, upon the processes at work; and thirdly, the time these have been at work, and the stage in the operation which has been reached.

Cañons. - This is perhaps the most striking sub-type. Cut deep in horizontal strata, with vertical or almost vertical walls often extending for great distances, these. 
earth trenches form very striking examples of young valleys. Horizontal, or nearly horizontal, strata are the first requisites, with the joints which are found in all rocks. The second consideration is that down-cutting predominates over lateral cutting; this is due to the climate, but is partly dependent upon the velocity of the stream and the extent to which it is armed with cutting tools in the form of sand grains. Thirdly, the uplift is comparatively modern, and the gorge is still in the young stage. It must, however, be remembered that given similar rocks in a region where the atmosphere contains much more moisture, the lateral weathering may cause the river gorge to assume a much more advanced stage.

The type cañons of the world are, of course, those of the great plateaux west of the Rocky Mountains. The Grand Cañon of the Colorado is described in most books of Physical Geography and referred to in almost every text-book of Geology. It is more than 200 miles long; its width varies from 5 to $I 2$ miles, and it is nearly 6000 feet deep. The upper part is often much less steep, and was evidently cut when the atmospheric conditions were different, and lateral weathering was more in evidence. The lower part is in places bounded by vertical walls of great height.

As already mentioned, cañons are found in other parts of North America, especially in the great region of plateaux between the Rocky Mountains and the mountains bordering the Pacific Coast. The nearest approach to these in grandeur are the deep trenches of the Southern Abyssinian plateau briefly mentioned in Chapter II.

Gorges. - There is no hard-and-fast line dividing the gorge from the cañon. In general it may be said that a gorge is a small cañon, Gorges are cut by rivers in 
horizontal strata where especially pronounced jointing facilitates this process, as was instanced by the gorges of the Loess, the Quader-Sandstein of the Elbe, the Tarn, and the limestone gorges of the British Carboniferous.

Transverse River Gorges.-Deep river gorges of a more irregular character are often found where a river runs transversely to a young mountain chain. The Alps abound in magnificent examples. Many of the feeders of the Rhine and Rhone come from the inner parts of the Alps in a direction roughly at right angles to the trend of the mountains, and in almost every case a deep gorge has been cut out by the debris-laden stream. The fine gorges of the Schyn and the famous Via Mala on the Hinter Rhine system are examples from the east of Switzerland; the Schollenen gorge of the Reuss and the renowned Aar Gorge are well-known examples from Central Switzerland; the grand gorge of the Trient, near Vernayez, may serve as an example from the Western Swiss Alps. Of course there are many more in the Alps; the above are well known and are easily reached from tourist centres.

The Indus cuts the western end of the Himalayas transversely in a series of gorges which are said to be almost impassable. The gorges of the Brahmaputra at the eastern end of the same mountains are so stupendous and so difficult of access that the course of the river was marked by dots on maps which are yet in common use. The Yang-tse-Kiang runs for some time concordantly with the trend of the folded mountains already mentioned; then it cuts across them, and its transverse gorge is one of the finest in the world.

To refer to the Rhine and Rhone again. Both rivers run for many miles in longitudinal troughs, the 


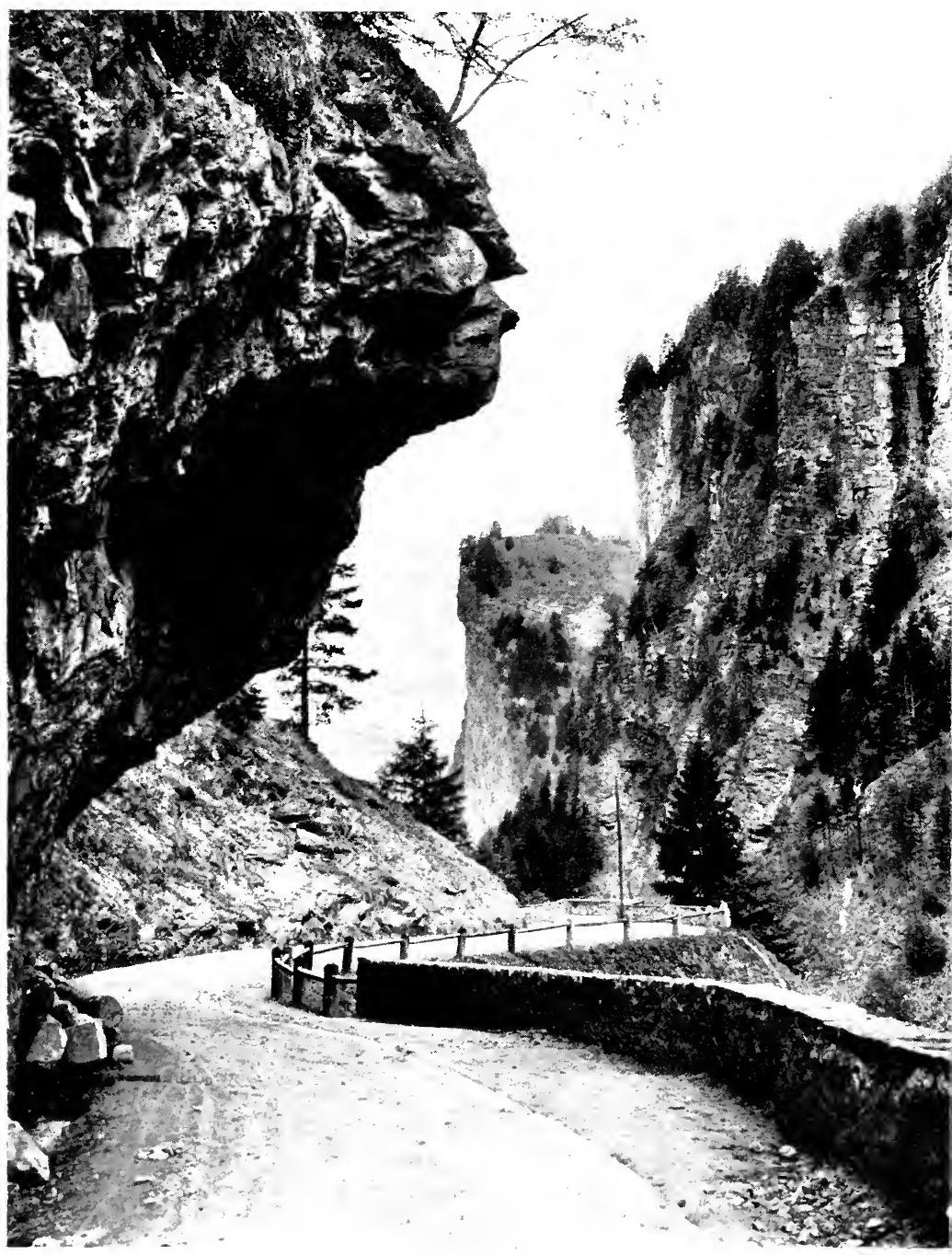

PLATE XI.- THE VHA MALA, A TYPCAL TRANGIERSE GORGE IN THE RHAETAN AHPS. THE HINTER RIINE CUTS THROUGII TO JOIN THE VORDER RHINE. 
valley of the Vorder Rhine continuing the direction of the Rhone lengthways between the line of the middle Alps and the long line of the Bernese Oberland and the Tödi Alps. Each river then cuts across the outer range from its inner Alpine trough: the Rhone at Martigny; the Rhine near Sargans. These transverse valleys are, however, comparatively wide; though that of the Rhone is clearly a trench cut right through the Alps, thus separating the Chablais Alps from the western Bernese Oberland. The Diablerets and the Dent de Morcles are obviously the same in structure and belong to the same system as the Dent du Midi on the southern side of the Rhone.

There are many other transverse gorges of great interest but of somewhat different type. The Rhine from Bingen to Bonn trenches across the European Mittel-gebirge, a comparatively shallow gorge cut in a plateau of ancient rocks. The Meuse from Givet to Namur cuts across the Ardennes massif similarly. The uplift of the Ardennes-Eifel-Westerwald plateau has been comparatively recent. The river seems to have been in existence before that uplift and to have cut down as fast as the block was raised, so that the Rhine of the Rift Valley was apparently not converted into a lake. The river was antecedent to the uplift, but we must be careful not to assume that every case of a transverse gorge is due to an antecedent river cutting down through a later uplift.

The transverse river gorges just mentioned are of very great importance in connection with the movements of man. In peace and in war, in mediæval times and in modern trade, they have provided the routes by which man has travelled. The sides of the gorge of the Rhine are crowned with mediæval castles, 
and its every point bristles with interesting mementoes of the march of armies and the passage of traders.

The typical cañon of the arid plateau, the gorge through jointed limestones and sandstones, and the transverse gorge through folded mountains or incised in a plateau uplift have one feature in common : they are U-shaped valleys of varying acuteness, such as may be diagrammatically represented by such forms as the following:

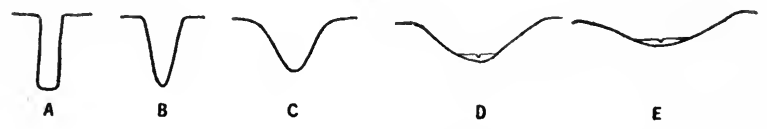

Fig. 17.-Diagrams of Valley Forms.

A. Very young stage; cañon or similar gorge. B. Young stage ; shoulders still angular; V-shape acute. C. Adolescent stage; shoulders rounded; V-shape much less acute. D. Mature stage; alluvial deposit forming in the broad bottom of the mature valley. E. Old-age form; very shallow valley, with alluvial deposits of greater extent.

In the shallower ones lateral cutting has been proceeding for a long time, and so the river only appears as a narrow streak in a broad-bottomed valley. The Rhone gorge from Martigny to St. Maurice is a good example of this type. Transverse valleys are valleys of erosion, but longitudinal valleys are often not valleys of erosion in the same sense; many are synclinal valleys with a long extension, following, as the geologist says, the strike of the strata. Longitudinal valleys occur in regions of folded mountains, the river running more or less parallel to the direction of the folded beds. Thus the Rhone and its valley are longitudinal, between the parallel Pennines and Bernese Oberland from the Furka Pass to Martigny. So the Rhine is 
longitudinal from the foot of the Oberalp Pass to Chur. There are good examples of longitudinal river valleys in the Jura, where the series of comparatively gentle folds allows of the ready production of such valleys: Many. rivers are by turns longitudinal and transverse, a good example being the Doubs.

The upper Indus occupies a longitudinal valley on the northern side of the Himalaya; the upper Brahmaputra runs for hundreds of miles in a great longitudinal valley between the Himalaya and the trans-Himalaya or Tibetan Himalaya. The longitudinal valleys of the great river system of further India and Indo-China have already been mëntioned.

These valleys offer routes for penetration right into the heart of mountain countries. Thus the long reaches of the upper Rhone and the Vorder Rhine have directed many movements of people in the Alps.

Anticlinal Valleys.-The summit of an anticline clearly offers itself to attack by weathering agents. Cutting down begins and continues with relative rapidity, and in time a kind of longitudinal "valley" may be produced with its long axis extending along the upfold of the rock. The Weald is not a valley in the strict sense, but is a sort of shallow basin area produced by the cutting down of the anticline (see the description and section in Chapter II.). Murchison long ago pointed out the existence of such valleys in the Silurian strata in Shropshire, where the summit of the Woolhope anticline has been dissected away and a valley produced. The middle Ribble of the Clitheroe district runs along the upfolded strata of an anticline, the long-continued dissection having cut down through the Coal Measures, Millstone Grit, and Upper Carboniferous Limestone, until beds almost at the base of that series are revealed. 
Similar longitudinal valleys, following the direction of dissected anticlines, are found in the Jura, in southern Ireland, and in the Appalachian region, in which many of the valleys are of the more normal synclinal type.

\section{BIBLIOGRAPHY}

(I) The Scenery of England. Lord Avebury. Macmillan \& Co.

(2) The Scenery of Scotland. Sir A. GeikiE. Macmillan $\&$ Co.

(3) The Scenery of Switzerland. Lord Avebury. Macmillan \& Co.

And see the Bibliography at end of Chapter II. 


\section{L.AKES AND LAKE BASINS}

THERE have been many classifications of lakes proposed, almost all of them from a genetic point of view. Whilst it is possible to classify very many lakes without much hesitation, there are many of mixed origin, and in the case of some of the most important lakes of the world there is still sharp controversy regarding the mode of origin. Prof. W. H. Hobbs enumerates no less than 28 types, and Prof. W. M. Davis has reduced lakes to three great groups. It would seem that from the point of view of the geographer as interpreted in this book the following classes include most of the lakes of importance :

I. Relics of comparatively recent seas.

2. Undoubted tectonic basin-lakes.

3. Lakes produced by the damming of normal drainage by some kind of deposit or other impediment.

4. Solution lakes.

5. Crater lakes.

Relics of Recent Seas.-Imagine a portion of the ocean which has been cut off by local elevation and at the same time, and perhaps partly in consequence of the tectonic changes, becoming drier; this cut-off sea may dwindle in area until it is only comparatively a relic of the ocean basin or Mediterranean Sea from which it has been derived. Such relict seas are the Caspian and Sea of Aral, possibly also the Salt Lakes of 
Central Australia, and such lakes as Tchad in Equatorial Africa. The Caspian still contains seals, fishes, and mollusca, which show its former connection with the Arctic Sea. There is little doubt that it once communicated with the Black Sea also. Such inland seas would, as may be expected, vary considerably in size both in successive years and from one season to another.

In the recently uplifted coastal plain of south-eastern North America there are very shallow lakes which correspond to shallow depressions on the sea floor. They are gradually disappearing owing to the accumulation of the debris of aquatic vegetation. These latter, of course, in no way depend upon an arid climate as do the seas in the mid-continental low plains.

Tectonic Basin-Lakes.-The existence of these lakes has been mentioned already in dealing with rift-valleys and with negative or depressed crust blocks. In many of these depressions there exist portions which are lower than the general or average level, and in these basins water accumulates and permanent lakes result. The Dead Sea of Palestine occupies a very deep hollow in the narrow Syrian part of the great Nubian rift-valley. The deepest part of the Syrian depression is about 2500 feet below the surface of the Mediterranean Sea. In an earlier period, when there was a greater rainfall, it partially overflowed to the Gulf of Akaba; now it is a small basin with water of high salinity, and well deserves its name, the Dead Sea.

The series of salt lakes on the East African plateau, of which Lake Rudolph is the best known, are in the same rift-valley, and also the fresh-water Lake Nyassa, which drains southward to the Zambesi. Lakes Tanganyika and Albert Edward are tectonic lakes occurring in another rift-valley which is probably connected with the East African one. 
Salt Lake in Utah is of a similar origin and has similar relationships. It is the residue of a once great fresh-water lake, but owing to the increasing aridity of the climate it is now a salt lake and receives the drainage of an enclosed tectonic basin. There are many other salt lakes in the same region.

Lake Baikal is a tectonic basin lake, the deepest lake basin in the world (see Chapter VI.).

Lake Balaton in Hungary is a deep part of the Hungarian depression, and may be regarded as a relic of the old Hungarian Sea ; it is thus partly a tectonic lake and partly a residual lake.

The lakes of the Great Glen of Scotland and many other Scottish lochs are almost undoubted examples of lakes in tectonic basins, and it is highly probable that many other lakes are of similar tectonic origin.

Lakes due to Damming of Normal Drainage.Lakes of this general class are very numerous, and there are many sub-classes, as there are many ways of holding up rivers and thus forming lakes. The moraines of glaciers frequently extend across a valley and form a lake by damming up the river. Many of the lakes of Scotland, the Lake. District of England, and other recently glaciated regions have moraines at the end, and are therefore partly, at least, of this class ; but in some cases they are also probably in part rock basins due to fracture. Some writers say that at least ninety per cent. of the lakes in recently glaciated regions are of this kind.

Glaciers themselves frequently dam up rivers; the best-known European example of this is the great Aletsch glacier of the Alps, which dams up a river and forms the Marjeelen See. Similar glacier-dammed lakes are found in other Alpine regions. Such lakes were probably of frequent occurrence in the British 
Isles in the Pleistocene glacial period, for there are undoubted evidences that glaciers extended across valleys, or opposed their fronts to the normal drainage of pre-glacial times. The famous Parallel Roads of Glen Roy, near Ben Nevis, in Scotland, are now believed to be lake terraces formed at different levels by the successive lowering of a lake dammed up by a glacier which extended across the lower end of the valley. These old terraces were long a source of difficulty to geologists and geographers. Many British north-country valleys show some traces of old lake terraces, but these are seldom or never so well developed as in Glen Roy and some of the neighbouring valleys.

A landslip or rockfall may fall athwart a mountain valley and thus impede the normal drainage, and a lake may result. This may obviously happen most frequently in Alpine regions where great rockfalls are of frequent occurrence. Such lakes will clearly be of a temporary character; the obstruction will soon be cut through. Well-known examples have occurred at Bellino in North Italy, in Carinthia, and in the Upper Ganges valley. Ox-bow or cut-off lakes of rivers may be included in the present wide class. A river forms a meander or loop which brings it back almost upon itself. The narrow neck of land between the two ends of the loop is burst through at a time of flood, drifted material shuts off the old curve and a loop-lake or cut-off lake is formed. Almost all large rivers flowing along alluvial plains have formed these curved ox-bow or loop-lakes. They are usually fairly shallow with deeper parts on the convex side, as would be expected from their manner of formation. The ox-bow lakes of the Mississippi are famous. Similar lakes are known as billabongs in Australia, where they are well developed on the Murray. 


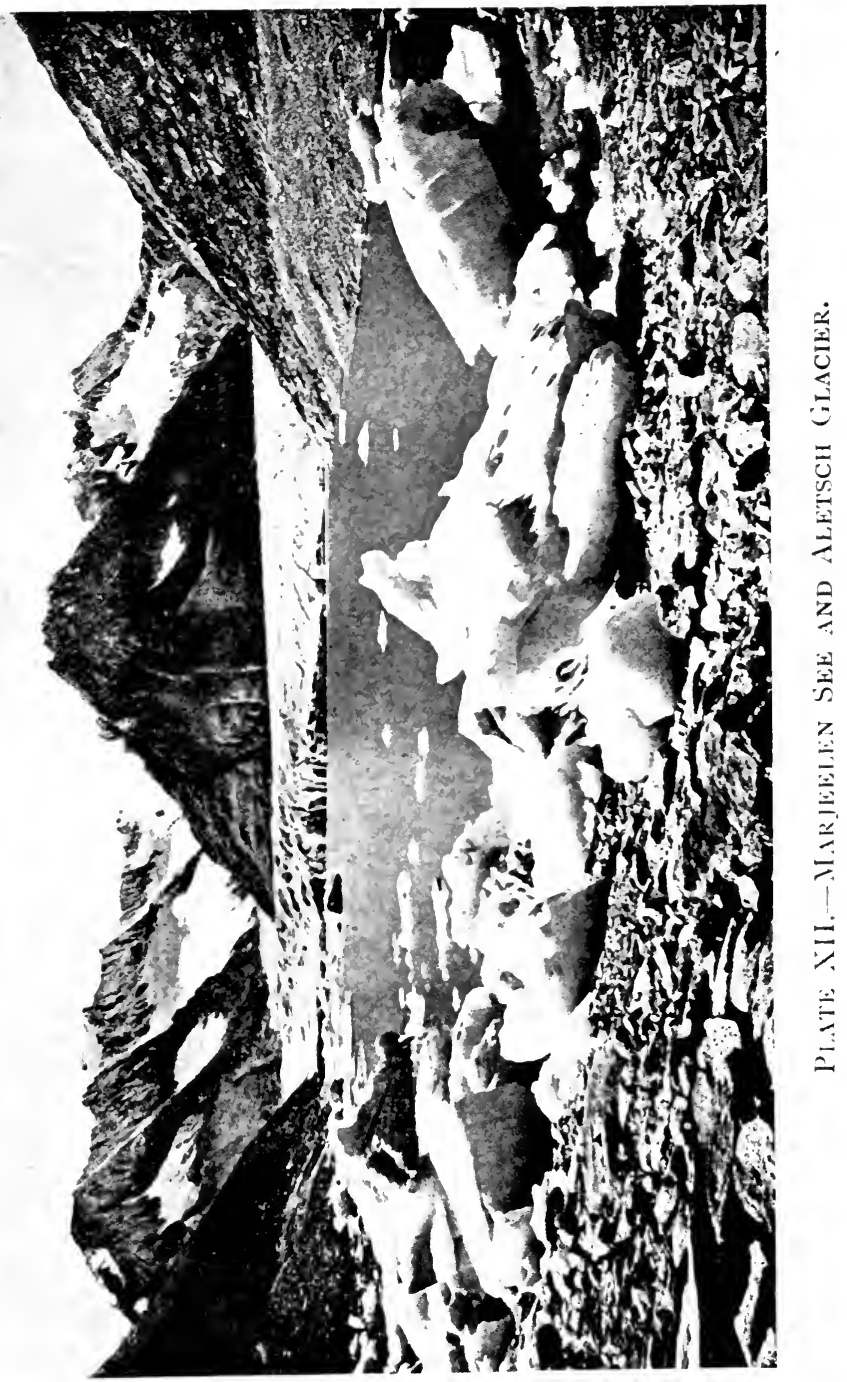



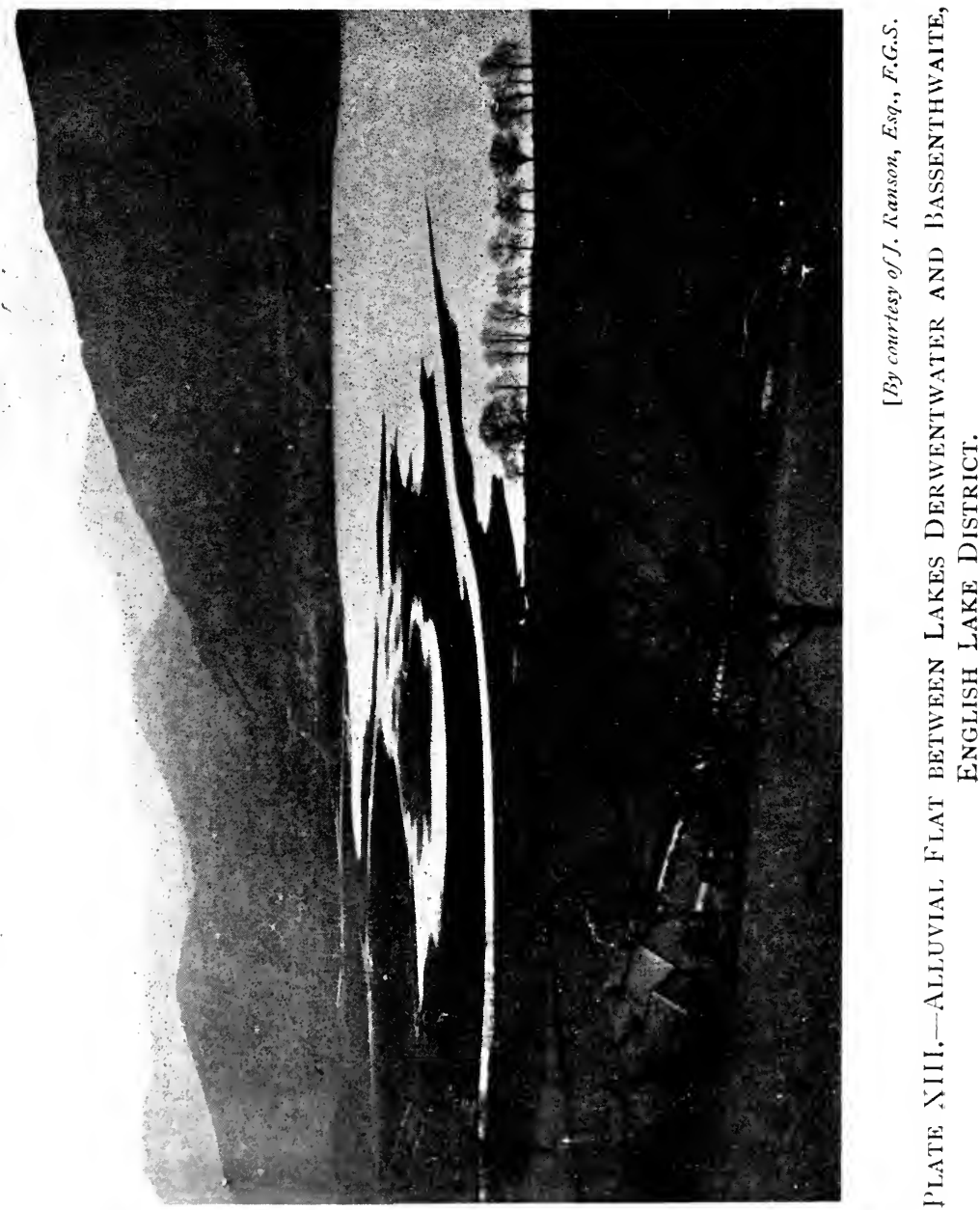
Very closely related to ox-bow lakes are the lakes outside the raised banks or levees of large rivers, and formed either by overflow from the river or from tributary drainage which is unable to join the main stream because of the raised banks. These are numerous on the lower Mississippi, on the Ganges, the Po, and many other rivers which have well-developed alluvial plains.

Lakes formed within deltas are somewhat similar in origin. The distributaries of the river pile up mud banks, the union of two of which may enclose sheets of water. The great lakes near New Orleans, the delta lakes of the Po and the Danube are examples.

The famous Broads of Norfolk are shallow fresh-water lakes with ill-defined banks of sedges, rushes, and other water plants. The sluggish Norfolk rivers originally emptied into a wide estuary, which the drift of material has closed. The tides sweep much material along from the rapidly dwindling coast near Cromer and from the more distant coasts of Lincolnshire and Holderness. First spits of land would be formed, then deposits of river sediment would break up the estuary into irregular channels, and portions would be partly cut off by the rapid growth of water-vegetation. These ponds are of very recent origin, and are already rapidly diminishing in depth and area, partly by deposition of ordinary sediment and partly by the accumulation of vegetable debris from the luxuriant growth of marsh-plants.

Lagoons on low coasts, which are dammed up by sand dunes, are common in many parts of the world. Those of the Great European Plain have been mentioned already. In south-west France the lagoons of the Landes are of similar character and origin. Another series of such lagoon lakes is found in south-west Russia along the shores of the Black Sea. 
Raft Lakes are due to the accumulation of drifted vegetation, which in time dams back the river. The most famous are those of the Red River of Arkansas and Louisiana. The raft forming one such "lake" has recently been removed to some extent, and precautions have been taken to prevent its re-growth. The White Nile, in the Sudan, is dammed up in the same way by the sudd, and wide marshes are formed where a great deal of the water of the river has been lost by evaporation. This impediment is also being removed so as to recover some of the land, reduce the tendency to malaria, and to conserve the water of the Nile.

It remains to be mentioned that the barrier to the normal flow of a river may be a lava-flow which dams back the water and forms a lake. Some of the famous lava-flows of Iceland in $I 783$ flowed athwart the Skaptar and its tributaries and.formed lakes. Snag Lake in California and Lake Tiberias in Palestine are other examples.

There are other ways in which barriers may interrupt the normal drainage of a river, but the above are the most important types. The student will readily understand that all these "barrier" lakes must be relatively short-lived. They are mere episodes in the long geographical history of a region. Whether the barrier be rockfall, glacial moraine, ice, blown sand, river deposit, or vegetation, it is obvious that the outflowing river will tend to cut through it, and so drain off the lake.

Solution Lakes.-Many rivers flow over limestone rocks. To take the rivers of Central Ireland as an example, these flow slowly across the plains and they are laden with peaty matter, and consequently contain organic acids. The river water thus dissolves some of the limestone and forms irregular river expansions of 
no great depth and of very irregular outline. Morainic matter left by the glaciers of the Pleistocene Glacial period assists in damming up the water, and the etching effect of the peaty water, with its organic acids and dissolved carbon dioxide, is seen in the irregular surface. These lakes are thus, partly at least, composite in origin.

The wonderful limestone region of the Karst, to the north and east of the Adriatic Sea, shows everywhere the results of solution of the Mesozoic limestones. The whole surface is fretted and etched by the solvent action of the fiercest rains of Europe. Here and there are funnel-shaped openings, where the solvent water has eaten its way down through some crack or joint, and through which the water now finds its way to the underground drainage so characteristic of the district. Sometimes these dolines are stopped up by fine sediment at the bottom and a temporary lake-bowl results. The larger and more irregular sunken parts are probably small rift-valleys. These are called Polyen. In the wet season these may be covered with water, which rapidly disappears, however, in the hot summer. The soil that has been washed into these sunken basins is very fertile, and consequently these depressions are relatively thickly peopled. The swamps which are common in these basins, are, however, fever-laden, and as they are ill-ventilated the fertility of their soil is largely discounted. Lake Zirknitz is perhaps the most famous of the seasonal lakes of the Karst land. It is usually dry in late summer and autumn, and reaches its maximum depth on the melting of the snow in spring. Lake Janina in Epirus and Scutari in the Montenegrin mountains are permanent lakes probably of similar origin.

Crater Lakes.-In many volcanic regions the craters 
of dormant or extinct volcanoes are occupied by circular lakes. Lake Avernus, near Naples, is the classical example. There are others on the famous Phlegræan Fields. In Central Italy, the lakes Nemi, Albano, Bolsena, Bracciano, and others ; in the Auvergne, Lake Pavin and others; in the Eifel, the Laacher See and the other "Maare" of that region of extinct volcanoes; these are well-known European examples. Lake Gustavila in Mexico is a large lake of this type. "Crater Lake," in Oregon, has a diameter of over five miles. There is a lake in the crater of Poas, in Costa Rica, from which steam and mud are ejected at intervals. There are crater lakes in the dormant or extinct volcanoes near Lake Nyassa and associated with the East African rift valley. In the crater of Soufriere in St. Vincent, West Indies, there was a small lake before the eruption of I902; and similarly before the classical eruption of Vesuvius in A.D. 79, a lake had been formed in the crater of Monte Somma.

There is little dispute about the origin of the classes of lakes discussed up to this point, but there are many which are not so easy of explanation and about which there has been much difference of opinion, and the points in question are by no means yet settled. The following are some of the lake types in dispute :

(a) Rock-tarns, chiefly in mountain regions.

(b) Glen or ribbon-lakes in mountain regions.

(c) Such lakes as the fresh-water lakes of North America.

Rock-Tarns are generally small lakes lying in rockbasins in mountain regions. They often seem to be quite independent of fracture lines, and their sides are almost always glacier-worn. These rock-basins are generally believed to be independent of subsidence and 
to be due to powerful erosion. Many geologists have unhesitatingly put them down to the gouging action of ice, though this explanation would not be accepted by all. There are hundreds of them in the Highlands of Scotland, and they are especially numerous in the Island of Lewis, where in some parts the map shows almost as much water as land. Finland and the Laurentian plateau (or peneplane) are dotted over with similar rock-tarns.

Loch Coruisk, in the Island of Skye, has been carefully studied by Harker. He has shown that the whole basin is clearly surrounded by rock except for a gravel deposit at the upper end, and that the bottom is bare rock also. The rock is gabbro, a rock of much toughness and durability. This hard rock has been ground smooth, polished and striated, and the hardness enables the gabbro to retain all the marks of glacial action with a freshness which makes it difficult to realise that the ice departed many thousands of years ago.

Among British lakes in other localities Thirlmere and Watendlath Tarn in the Lake District, and Cwellyn and Glaslyn in Snowdonia, have been considered to have a similar origin.

Glen Lakes, or Mountain Ribbon-Lakes. -These include the longer and larger lakes in the Highlands of Scotland, and the great valley lakes of the Alps and of Alpine regions generally. This type has given rise to much discussion. One school of geologists, following Ramsay, has taught that they have been scooped out by ice; and for a long time this was accepted. A later school of geologists has taught that glaciers cannot erode rock-basins. So the question of the origin of these lakes has been merged in the general question of iceerosion. 
The truth probably lies between the two extreme views. Many of the Highland glens of Scotland are primarily tectonic in origin. River action continued for long ages has cut deeply into the table-land of hard rocks. During the glacial period weathered material was carried down by the glaciers, some protruding rockmasses were removed, and smooth striated surfaces were imparted to many of the rocks. Moraines were accumulated in some of the lower parts of the valleys. Perhaps during the recent change of level, of which there is abundant evidence in Scotland, there was sufficient warping or irregular tilting of the country to assist in the production of over-deepened basins. In all probability two or more of the agencies have assisted in the production of the lakes. The same causes have probably operated in the production of the lakes of other Alpine regions. It is now very definitely assumed by many geologists that such lakes as Lucerne, Thun, and Geneva, and the Italian Alpine lakes, are partly due to movements which affected valleys which had been formed by ordinary frost and river erosion in pre-glacial times. The uplifting of an outer zone caused a damming back of the river drainage, and unless the river erosion could keep pace with the rate of uplift a series of lakes would obviously result. The extension of the glaciers, the production of great moraines and the erosive action of the ice sheets have given to these lakes many of their modern characteristics, though originally their origin was tectonic, following on river erosion. The question is by no means settled yet, however.

The Great Lakes of the St. Lawrence.-The five great lakes of the St. Lawrence constitute the largest fresh-water system in the world, and are obviously of tremendous importance in the physical and economic geography of North America. The question of their 
origin is as difficult as that of the Alpine lakes just mentioned, and geologists are by no means agreed. It is usually regarded as quite certain that the lakes were not in existence in pre-glacial times, and that during and since the glacial period three causes have been at work: (I) Changes in level of the earth's crust, of a local and uneven character; (2) some amount of glacial erosion; and (3) damming up of drainage by deposits formed across pre-existing valleys. The relative value of each of these agencies is obviously difficult or impossible of determination, and it is more than probable that the effectiveness of these causes has been different in the different lakes of this important system. There is again much difference of opinion as to the value to be attached to ice-erosion; some think it the most important of all, while others would regard it as only of secondary importance.

Very similar considerations probably apply to the North European system of fresh-water lakes. It may, however, be pointed out, that a pronounced line or belt of depression extends from the Norway Deep across Sweden, the Gulf of Finland and the Great Lakes to the White Sea. The student should study a good orographical map of Northern Europe to appreciate the significance of this remarkable belt of depression. Lakes Wener, Wetter, and Malar in Scandinavia, a deeper part of the Northern Baltic, the Gulf of Finland, Lakes Ladoga and Onega in Russia, and the White Sea are apparently parts of this great curved belt of depression.

Salt Lakes.-Lakes continually lose water by evaporation and seepage. This loss is made good by inflowing rivers. If the supply of water from rivers is more than sufficient to make good the loss, there is an outflowing river or rivers, and the dissolved salts in the water of the lake are approximately the same in kind and in 
quantity as in the water of the inflowing rivers. The quantity of salts is too small appreciably to affect the taste and the lake is said to be a "fresh-water lake." If the supply of water is insufficient to maintain an outflow the proportion of dissolved salts must clearly increase as the inflowing water is evaporated, and the lake is a "salt-lake." This concentration of salts continues to saturation point-which is often reached first in some shallow gulf or bay of the lake-and precipitation of some of the salts occurs (see Chapter X., Salt Deposits in the Strata). Salt lakes occur in all the continents in regions where the rainfall is scanty, the atmosphere usually very dry, and evaporation proportionately rapid. The regions where they occur are frequently known as regions of closed or internal drainage.

\section{Lakes are transitory Features of the Earth's Surface.} - Judged by geographical standards, lakes cannot be very long-lived features as a rule. Two processes are often at work shortening their existence as lakes. The first is the cutting down of the barrier by the outflow, a process which will obviously in course of time lower the level of the lake until the complete cutting through of the dam may eventually drain off the whole lake. The other process is that of deposition, the filling up of the lake with deposits brought from the higher reaches of the rivers which feed the lake. This latter process is obvious and well known. Many concrete examples can readily be given. Three well-known ones must suffice. Lakes Derwentwater and Bassenthwaite are obviously part of a former great continuous sheet of fresh water, but the rivers Greta from the east and Newlands Beck from the west have brought down alluvium until they have formed the large flat to the west of Keswick which now separates the two lakes. 
An exactly similar process has divided lakes Brienz and Thun in the valley of the Aar in Switzerland. A side tributary from the Bernese Oberland has pushed its delta completely across the valley, thus making two lakes where formerly there was one continuous sheet of water.

The silting up of Lake Geneva by the Rhone is a very well-known example. The great river comes through its transverse gorge turbid with glacial mud and other river-borne materials which it deposits in the upper end of Lake Geneva. In this way some square miles of deltaic deposit have been formed since Roman times. Near the town of Geneva there may be seen the difference between two rivers originally charged with glacial mud, one of which has dropped its suspended material while passing through a lake, and the other has not. The Arve flows as a turbid stream laden with so much fine clay that a cement works has been set up to utilise it; the Rhone is a clear stream. The waters of the two streams mingle but slowly, and the remarkable difference between them may be seen for a considerable distance.

Unless some change in conditions is set up within the immediate geological future, Lake Geneva, and many another Swiss lake, will cease to exist. In its place there will be a flat, alluvial land, and such are quite common in all mountain regions where lakes occur. The present lakes seem only a small part of the lake systems which existed at the close of the last glacial period.

Vanished Lakes of different types are common in many parts. In the Pennine valleys are traces of many shallow lakes or meres, some of which have been completely drained in comparatively recent times. Professor P. F. Kendall has shown that a series of lakes existed in the northern valleys of the North York moors 
in glacial times, and he has reproduced some of their outlines with considerable care. Greater lakes are known to have existed in recent times in different parts of the continents. Lake Bonneville is the name given to a lake which existed in the great basin of North America in comparatively recent times. Great Salt Lake is a comparatively small descendant of this lake, whose terrace deposits are found at a height of about Iooo feet above the present lake level. A vast lake which existed in the prairie region of Central North America has been named Lake Agassiz.

Uses of Lakes.-One of the first and most interesting parts played by lakes in the economy of nature is that of control of the flow of rivers. Floods are checked by the lakes through which so many mountain streams flow. Especially does this apply to numerous rivers which derive their supply from the snows and glaciers of mountains. Lake Constance minimises the floods of the Rhine; the lakes of Central Switzerland control the floods of the Aar tributaries, and Lake Geneva equalises the flow of the Rhone. So obvious is this control of flooded rivers that the course of the Aar below the confluence of the Saone and near where it makes its great bend to the north-eastward, has been altered so that the river now flows into Lake Bienne, and thus the dangerous floods which were formerly characteristic of the Bernese Aar are now prevented. Exactly the same is seen in the case of the lakes of Scotland and the Lake District; the mountain streams are often flooded to a disastrous extent, but the rise of the rivers in flood time is far less than it would be if the flood water had not been spread over the greater surface of the lake or lakes. Since reservoirs have been constructed near the source of so many of the Pennine streams it has bẹn noțiced that disastrous floods are 
not nearly so numerous as they were formerly. Artificial lakes are playing the same part as the natural lakes of other regions.

Lakes, both natural and artificial, are used for supplying towns with water. Loch Katrine supplies Glasgow, and Thirlmere, in the Lake District, supplies Manchester. When the Lancashire city took over Thirlmere for a water supply, the natural dam was raised and the depth and volume of the lake considerably increased. The scenery of the district does not seem to have suffered materially in consequence of these changes. Crummock Water has been raised to increase its volume by the towns of Cockermouth and Workington, and the old footpath on the southern side of the lake is now submerged for the most part. It is interesting to note what a large number of artificial lakes or reservoirs are to be seen in that part of the Southern Pennines between the Aire gap and the Peak of Derbyshire. The prevalent rock is millstone grit, which holds large quantities of soft water; the rainfall is considerable, and the immense population of the neighbouring East Lancashire and West Riding manufacturing districts demands the storage of large quantities of water.

It is scarcely necessary to insist that lakes appeal to man from a scenic point of view. The deep, clear water of mountain lakes, lying among the majestic hills and often surrounded by forests, offer irresistible charms to the residents in the busy regions of the world, and the lands of mountain lakes are among the most highly favoured holiday regions. The lakes of the English Lake District; the wilder lakes of the Scottish Highlands; the lakes of the Alps, especially those on the Italian side, need only be mentioned.

It may also be pointed out that lakes have great direct economic value. The waters of mountain lakes 
supply energy which is now used in many ways in Norway and Sweden, in Switzerland and in North America. The great lakes of North America are also of great importance in providing a means of access for shipping into the middle of a wealthy continent.

Lakes and Climate.-Lakes exert some influence on the climate of surrounding lands. The water of the lakes cools the air in summer and warms it in winter, except when the lake is frozen over. The climate of Scotland and Scandinavia among European lands must be affected by the great expanse of water in the very numerous lakes, the humidity of the air is increased, and the range of temperature reduced. Large lakes will exert a still greater influence. The Great Lakes of North America must give to the air an enormous quantity of vapour and so affect the atmosphere considerably. It is due to the influence of the lakes that fruit-growing is such an important industry in the two great peninsulas-Ontario, between Lakes Ontario, Erie, and Huron, and Michigan, between Lakes Huron and Michigan.

The mild climate of the shores of Lake Constance, and the climate of Montreux, Vevey, and Lausanne on Lake Geneva, are well known, and are sufficient testimony to the ameliorating effect of the Swiss lakes. The delightful climate of some of the upper Alpine valleys on the Italian side, and the growth of the olive there, are in some measure, if only slightly, due to the deep Italian lakes.

\section{BIBLIOGRAPHY}

(I) Lakes of North America. J. C. Russell.

(2) The Scenery of Switzerland. Lord Avebury. Macmillan \& Co.

And the works of Geikie, Hobbs, etc., mentioned in the earlier chapters. 


\section{COAST-I.INES AND INLETS OF THE SEA}

COAST-LINES are of varied character, and as the type of coast possessed by a region is of first-rate importance in connection with its development and its trading possibilities, it is necessary to study them briefly. At the first glance coast types might seem to be too numerous and too varied for systematic classification, and as a matter of fact there is as yet no complete and inclusive scheme. We may, however, briefly indicate some points of geographical interest, and outline briefly some tentative methods of classification which have been widely adopted.

Concordant and Discordant Coasts. - Some coast-lines extend for long distances parallel to the strike of welldefined mountain ranges. They follow the grain of the country. Such coasts have been termed concordant, the name being self-explanatory. Other coasts cut across the grain of the rocks of the region; these are described as discordant coasts. Some examples will make this clearer. The Pyrenees form a well-defined Alpine mountain chain, with the grain of the folded rocks running on the whole from east to west. The Cantabrians continue this structure into the north-west of Spain. The deep inlet of the Bay of Biscay extends into the angle between the mountainous coast of the north of Spain and the low coast of south-western 
France. The southern shore of the Bay of Biscay is concordant towards the Cantabrians; it runs almost strictly parallel to the grain of the folded mountains. The bathymetric lines (that is, contour lines showing depths of sea-floor) of the Bay of Biscay on its southern side also run broadly parallel to the mountains, thus making the concordance more pronounced. At the western end the varied and broken coast of Galicia cuts across the grain of the rocks just as plainly as a transverse section of a long beam cuts across the grain of the wood. This western coast is discordant. It seems reasonable to suppose that the folded mountains once extended farther to the west. When the last phases of the foundering of the North Atlantic took place the fracture cut off the mountains sharply at their western end. Similarly, the Atlas mountains end off sharply at the western end. The northern, or Maritime Atlas, ends off abruptly in the Riff coast, the Great Atlas in the rocky coast of Cape Ghir, in both cases the grain of the rocks being cut transversely. The Great Atlas may have been cut off at the same time and in the same way as the Cantabrian mountains. The Canary Islands are mountain fragments, parts of that Atlas which once continued well out into what is now the North Atlantic Ocean. From Tangier to south of Cape Ghir is a typical discordant coast; the coast parallel to the Northern Atlas is a concordant one.

Most of the Pacific coast of both the Americas is concordant, the fold-mountains running parallel in a general way to the coast-line. There are obviously portions where, probably owing to subsidences, the coast becomes locally discordant; the northern end of Puget Sound, and the southern end of the peninsula of Lower California, will readily occur to the student as examples.

The eastern coast of the Persian Gulf, the eastern 
coast of the Bay of Bengal, and the coast of Kamchatka are other examples of coasts where fold-mountains run parallel in general to the coast-line.

We have hitherto regarded coasts chiefly in relation to folded mountains of Alpine type. We may, however, consider some of those regions where the folds have not produced mountains in the usual sense, but where the grain of the country (the strike of the rocks) is the same over a considerable area. The coast of Sussex is parallel to the general direction of the South Downs from Selsey to near Beachy Head; this is therefore a concordant coast. The English coast of the narrow seas from Beachy Head to the North Foreland evidently cuts across the grain of the country; it is a good example of a discordant coast. The corresponding coast of France is similarly discordant.

The Yorkshire coast from Bridlington to the mouth of the Tees is discordant, as it cuts across the grain of the Jurassic and Cretaceous rocks. The varied features of the coast depend upon the presence of a succession of hard and soft rocks cut across by the sea. The hard rocks stand out as headlands; the bays occur where softer rocks have been exposed to the action of the sea.

Discordant coasts show greater variety of structure than concordant coasts. Different types of rocks are met with in rapid succession and thus give rise to varied features. A discordant coast is usually rich in capes and openings, and very often rocky cliffs alternate with stretches of low flat beaches.

Neutral Coasts. - It is often the case that the rocks of a maritime region are practically horizontal, either level-bedded sediments or igneous rocks which have an even, horizontal extension. The coastal outline cannot be said to be parallel or oblique to the direction of the rocks or to the grain of the country. The 
direction or orientation of the coast is independent of the internal structure of the rocks. Such a coast, which cannot be described as either concordant or discordant, is a neutral coast. Where the plain of Northern China meets the China Sea is a typical example. The Tundra coasts of the Arctic regions are also typically neutral.

The coasts of the great European plain have been described as doubly neutral; there is an outer neutral coast and an inner coast behind the lagoons or wadden. Other examples, such as the Landes coast of the Bay of Biscay, will occur to the student.

Pacific and Atlantic Coasts.-The late Professor Suess of Vienna called attention to the remarkable difference between the coasts of the Pacific and those of the Atlantic. The great Pacific Ocean is largely bordered by long lines of young fold-mountains which run concordantly with the coast. The whole of the west coast of the Americas, with the exception of part of Mexico, has these long lines of mountains close to the sea. The continental shelf is narrow, or, in other words, the deep ocean comes very close to the coast-line. The same holds on the western side of the Pacific, only we must look for the real ocean boundary on the outer side of the long festoon-lines of volcanic islands and peninsulas mentioned in Chapter II.

Within the long system of islands lie inland seas, and behind these is the complex coastal system of continental Asia itself, a coast sometimes concordant, sometimes discordant, and sometimes neutral. Asia has thus a sort of double coast. There is a very similar system of double coasts in the West Indies and Central America.

The coasts of the Atlantic are quite different, scarcely anywhere is the outline parallel to long lines of fold-mountains. Slight exceptions, such as the north of Spain and possibly the north of the Gulf of Guinea, scarcely 
count in the vast extent of coast under consideration. The western coast of Norway is not of the Pacific type, as the grain of the old Caledonian Alps does not extend along the axis of Scandinavia, but has a direction more nearly north-east and south-west. Neither are the coasts of New England and Nova Scotia strictly concordant. The Atlantic coasts are extremely irregular. In one part Alpine mountains are broken off sharply against comparatively deep sea ; we have already seen examples on the north-west of Spain and in the northwestern corner of Africa. In another place a plateau ends off sharply with a fractured edge. Such is the west coast of the Spanish Meseta, part of the west coast of Africa, and a good deal of the east of South America ; in these cases the coastal plain is narrow and there is a very narrow submarine continental shelf. In yet other regions low plains, with low flat coasts, pass gradually into shallow seas where the continental shelf is obviously of great extent. The coasts of the south of the North Sea, the western coast of France, the south-eastern coast of the United States, and the coasts of Argentina are obviously of this type. Most of these are neutral coasts, as already pointed out. The distinguishing character of the Atlantic is this irregularity, contrasted with the regular type which holds for so much of the Pacific.

The Indian Ocean is bounded by varied coast-lines of Atlantic type, that is, discordant and neutral coasts, both on the African and Australian sides, and in most of Southern Asia. The only exceptions are the Pacific types of the Persian Gulf and the possibly modifiedPacific coast of Burma and the Malay Peninsula.

The Pacific coast of America has islands running chiefly in long lines parallel to the general coastal trend. Note, for example, the islands off the coast of 
British Columbia and those off Southern Chile. On the western side the long festoons of Eastern Asia and Malaysia show to some extent the same linear arrangement. The islands of the Atlantic are irregular, detached continental masses; Newfoundland is part of eastern North America with its grain abruptly cut off and indicating a former extension into the North Atlantic. The British Islands are a part of north-western Europe, quite recently detached from the continent by the discordant breach of the Strait of Dover and the English Channel. The Canary Islands are fragments of the Great Atlas, where the latter extends out into the Atlantic almost at right angles to the general north and south direction of the ocean.

The Atlantic, with its variety of coast-line, has a varied hinterland, which on the whole is much more readily approachable than the immediate hinterland of the Pacific. The great wall of the western mountains and the plateaux of the Americas must always prove serious barriers to communication between the ocean and the immense continental plains. As with eastern North America so with Europe, the varied and frequently discordant coast offers many avenues of access to the continental interior. This is not without its bearing upon the advanced state of civilisation of these continents, and especially important in its bearing upon those possibilities of interchange of commodities which play so important a part in modern life. The disturbances on the western Pacific margin in recent geological times which have depressed the long mountain lines, so that many of their higher parts stand up as islands from a comparatively deep sea, have provided openings from the ocean to eastern Asia which make it more favourably situated for trade than western America. 
Other shorter Pacific coasts show some of the same principles. Persia is shut off from the Persian Gulf and the Arabian Sea by the Alpine wall of the Zagros mountains, passes through which are difficult. Persia must wait for the advent of Alpine tunnelling on a considerable scale before its oases and river valleys are brought fully into touch with the outer world on the oceanic side. Burma is accessible from that stretch of discordant coast which runs athwart the direction of the Irrawadi and Salwen rivers. Communication across the mountain wall running parallel to the eastern coast of the Bay of Bengal is difficult, and access to the interior is now provided by railways which run parallel to the fold-mountains and not across them.

It should be pointed out here, however, that discordant and neutral coasts are not always conducive to ready appróach to continents. Plateaux frequently end off abruptly, the ocean on their margins having apparently foundered. Eastern South America has much in common with parts of western Africa, and it is believed that the South Atlantic is a foundered portion of the crust which formerly existed as a land connection. So also Eastern Africa, the Deccan, and the plateau of Western Australia are so much alike that geologists believe them to be portions of a continent of the Mesozoic era, to which Professor Suess gave the name Gondwanaland (see Chapter II.). The coasts of these broken plateau-systems are notoriously difficult, and the coastal plains are narrow; rivers usually descend from the plateau in waterfalls which impede navigation, and generally such a plateau-continent is by no means easy of access. Eastern South America is fortunate in possessing the great basin of the Amazon between the plateau of the north-east and the East-Brazilian plateau. Here the coast-line and the structure of the land is of the same 
type as the Mississippi Basin, only on a larger scale, and the continent thus possesses a region to which Africa offers no real counterpart.

The Continental Shelf.-Where the sea meets the present land-boundary is seldom the real outer edge of a continent; the latter frequently extends as a submarine platform for some distance out to sea, then there is a comparatively rapid descent to real oceanic depths of from Io,000 to I5,000 feet. The shallow submarine continuation of the continent is known as the continental shelf:

Concordant coasts have usually a narrow belt of continental shelf ; discordant coasts vary considerably, but neutral coasts almost invariably have wide continental shelves. The existence of a wide shelf is of very great importance. On it most of the continental debris brought down by rivers is deposited. Here there is abundance of food for marine life; crustacea, mollusca, and fish are plentiful. The food supply of a maritime region is thus largely influenced by the nature and extent of the continental shelf, which in its turn is intimately connected with the type of coast-line.

Coastal Openings.-There is no complete classification which includes all inlets into the land. Even the common names-sea, gulf, bay-are used in varying senses. One only needs to compare the White Sea, the Baltic, the North Sea, and the Black Sea to realise in what various senses the name sea is used.

The partially enclosed seas of Central America furnish another example; we speak of the Caribbean Sea and the Gulf of Mexico, but the Mediterranean Seas concerned are of one type. It is sometimes understood that a gulf has a fairly narrow opening, and this holds for such well-known examples as the Persian Gulf, the Gulf of Mexico, the Gulf of Pechili. But we also speak 
of the Gulf of Guinea, the great " bight " of Western Africa. The name bay is also used for very different types of openings; compare Hudson Bay with the Bay of Bengal. Baffin's Bay is a curious example of the use of the word bay for a sea passage which was probably at first thought to be a bay. The Gulf of Aden and the Gulf of Oman are funnel-shaped seas leading through straits to inland seas, one of which is called a gulf, the other a sea. It is obvious that the whole nomenclature is full of anomalies.

The great Inland Seas. - The most famous of these are the European Seas, the Southern Group and the Northern Group. The Mediterranean Sea is the largest inland sea in the world, with a length of 2000 miles and an area of a million square miles, or eight times the area of the British Isles. It is divisible into welldefined eastern and western parts separated by the shallow Sicilian ridge. The Eastern Mediterranean descends to a depth of over I2,000 feet, the greatest depths being near the unstable regions connected with the fold-mountain system of Southern Europe. Crete and Cyprus are the higher parts of submerged mountain ranges. The Adriatic Sea is a depressed crust block between the Apennines and the Dinaric Alps. The eastern coast of the Adriatic is of a type almost unique, the Dalmatian type. The Western Mediterranean is divided by the SardinianCorsican horst, which separates the Tyrrhenian deep from the Ligurian Sea.

The Mediterranean shows examples of the three leading types of coast-lines. From the Riff Coast of Morocco to Cape Bon is concordant, as are also the southern coast of Asia Minor, the western Adriatic, and the Coast of Spain from Gibraltar to Cape de Gata. The north-eastern coast of Spain is clearly discordant, 
as is the southern coast of Greeece where the mountain upfolds form the promontories of the famous Morea. The west coast of Asia Minor is a heterogeneous coast mainly of discordant type. Neutral coasts are not so well represented in the Mediterranean, but the Northern Adriatic, the Carcassone coast of France, and the Oran coasts are examples.

The Black Sea is a deep gulf of the Mediterranean, approached through the narrow straits, the Dardanelles and Bosphorus. It has a maximum depth of 8600 feet, and is being filled up with relative rapidity by the numerous rivers which enter it. It is not so salty as the Mediterranean, its water containing about sixteen parts of dissolved salts per thousand against thirty-seven parts per thousand in the Mediterranean. A strong current flows from the Black Sea to the Mediterranean during most of the year.

The Northern Group of European Seas includes the Baltic, the North Sea, the narrow seas on the south and west of England, and the White Sea. These are all shallow seas. The North Sea and at least the Southern Baltic are parts of the Great European Plain depressed only very slightly below sea-level. The English Channel and the Dover Strait are also very shallow, almost all of it being less than 300 feet deep, that is, far less than the elevation of the North Downs, the South Downs, and the Forest Hills in the middle of the Weald. The shallowness of these seas, the great amount of continental debris brought into them and spread over their floors, and the moderately low temperature, make them amongst the most famous fishing grounds in the world. All the countries round the North Sea derive important food supplies from the fisheries of that sea.

The Asiatic Inner Seas,-From the Bay of Bengal 
all round the east of Asia runs a great series of mountain loops, many parts of which are depressed below sealevel, the summits only appearing as islands. Outside these curves of volcanic islands are the greatest oceanic depths yet known. Inside the curves are the submerged parts of the continent, forming the inner seas. These, while by no means shallow, are not nearly so deep as the great ocean outside. The seas thus partly enclosed between the outer primary coast of Asia and the inner secondary coast, are the Sea of Okhotsk, Japan Sea, Yellow Sea and East China Sea, and the South China Sea. The Yellow Sea is shallower than the others, probably because it has been filled up with so much continental debris from the easily-weathered loess lands of the interior. The Great Chinese rivers, Hoang-ho and Yang-tse, and the lesser Pei-ho bring down immense quantities of yellow loam which is deposited between the inner and outer coasts of the continent.

The Inland Seas of Central America.-These seas, like those of Eastern Asia, lie between an inner and outer coast. The primary or outer coast extends from the Bahamas through the Lesser Antilles to the Coast Range of Venezuela. This is a modified concordant coast, with, of course, many breaches due to sinking of the land and the penetration of the Atlantic. Outside this primary coast is the deepest known part of the Atlantic, another point of analogy with the Asiatic island-loops and inner seas. Between the outer line of islands and the inner coasts of the continent are the three sunken basins, the Gulf of Mexico, the Bartlett Basin, and the Caribbean Sea. The greatest depth in these Mediterranean seas is 20,560 feet, compared with 27,970 feet in the Atlantic immediately outside the curve of volcanic islands, 
Hudson Bay.-Hudson Bay corresponds to the shallow northern inland seas of Europe. Its average depth is about 400 feet, and its greatest known depth 660 feet. Like its European counterparts, it receives considerable continental drainage, and its floor must be covered with great deposits of continental debris brought down by the numerous rivers which empty their waters into it.

\section{Valley Openings}

Rias, Fiords, Fiards.-There are some types of openings into the coasts to which definite, fairly consistent names are applied, and the names of which connote certain clear ideas of structure and mode of origin.

Rias.-These are sunken, somewhat shallow, V-shaped valleys; as a rule they gradually become shallower and narrower as they are followed inland, and they end in gradually shelving shores, such that the slope of the valley inland is a continuation of the submarine slope of the opening. They branch but rarely. Rivers usually enter the bay at the upper end, but the width and depth of the valley frequently seem out of proportion to the size of the stream. The typical rias are the openings on the discordant coast of the north-west corner of Spain. They were studied and systematically described by von Richthofen, who gave the precise connotation to the name. Typical rias are generally found on discordant coasts where the full force of the tides is felt, and it is difficult to resist the conclusion that the waves have had a considerable share in forming this particular type of opening, if not by marine denudation, at least by maintaining them open through sweeping out deposits which would otherwise fill them up.

The openings of the west of Brittany are also rias, 


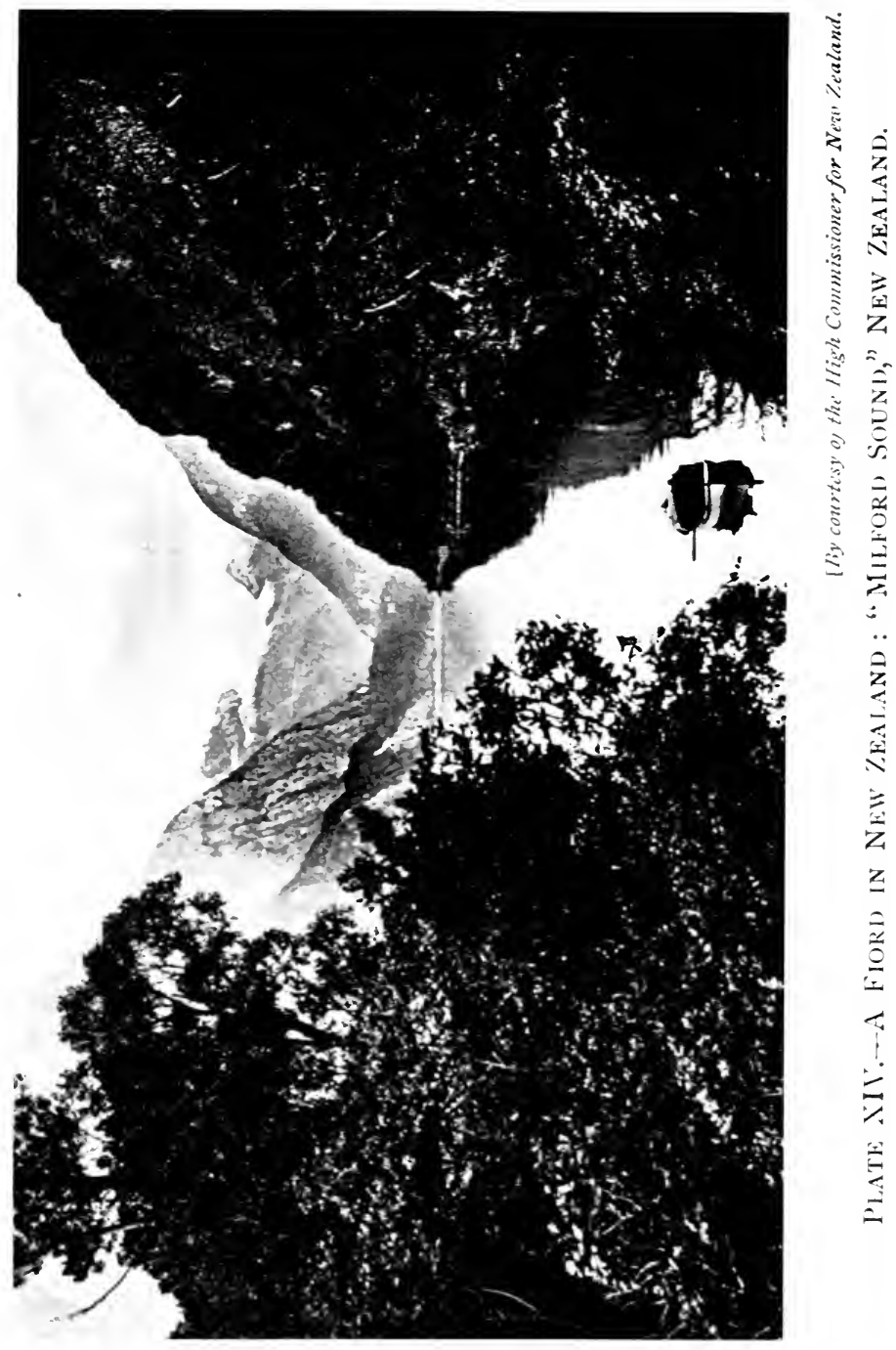




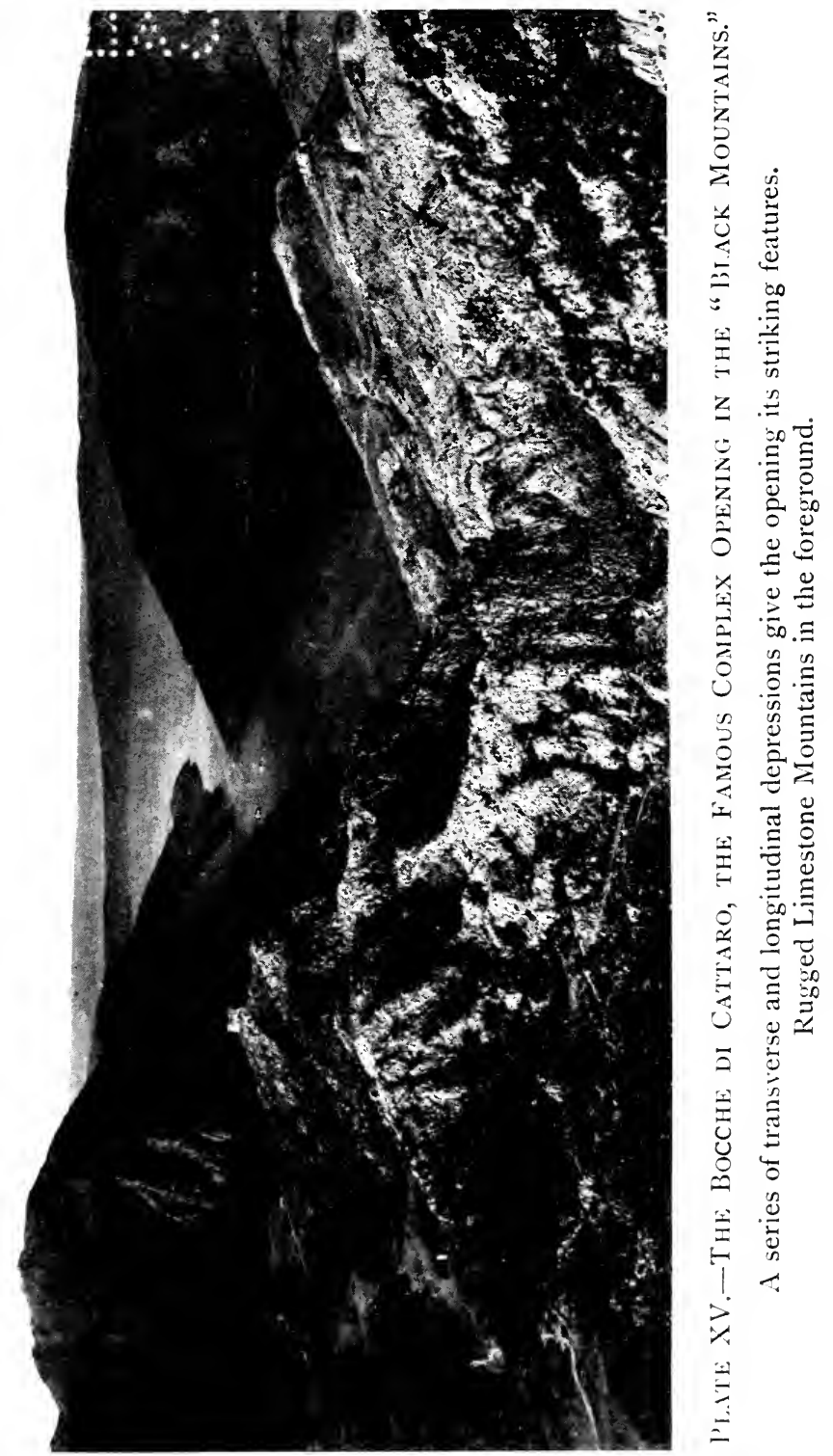


and excellent examples are furnished by the series of openings in Kerry, south-west Ireland. Other examples are found in southern China, on the Maine Coast in the U.S.A., in North Island, New Zealand, where Auckland Harbour is a typical ria, and in such openings as Plymouth Sound and Falmouth Harbour.

Fiords.-These are long, narrow openings, with steep walls, extending into the land for long distances, and often branching in a remarkable manner. They are very deep and often much deeper far inland than at the mouth; in fact, a great number of fiords seem to have some kind of submarine bar at the mouth, either of rock or of morainic matter.

Fiords are found in high latitudes, in countrie; now heavily glaciated or which were obviously glaciated in the Pleistocene Ice Age ; hence many writers have held that they are valleys which have been formed mainly by glacial erosion, obviously aided by river erosion. These openings occur in fractured tablelands or on coasts where there has been much disturbance during recent geological times. Where the faults have been carefully mapped it has been found that the fracture lines coincide to a surprising degree with the direction of the principal and branch fiords. It seems, therefore, that the fiords were probably determined in the first place by faults. River valleys developed along the shatter-belts of the fault lines, and these were cut deeply before glacial times. Glacier; probably once filled many of these deep-cut valleys, and their gouging and planing actions have possibly worn out some of the deeper parts, rounded off some of the sides, and especially glaciated the rocks at the entrances. Afterwards, in comparatively recent times, subsidence has caused the sea to fill the valleys, thus producing the present features. It would thus seem that subsidence, 
fracturing, river, ice, and sea action have probably all played a part in the production of fiords.

The typical fiords are those of the Norwegian coast, where Sogne Fiord, one of the best-known, extends inland for over Ioo miles, and has an average width of only three miles. Most of the openings on the west of Scotland and the north-west of Ireland are fiords. Across the North Atlantic, on the coasts of Iceland, Greenland (both east and west), and Labrador there are typical fiords. Fine examples occur on the west side of North America, in British Columbia and Alaska, and also in the extreme south-west of South America. Finally, on the west coast of South Island, New Zealand, there are fiords as grand as those of Norway.

It will be noticed that fiords occur both in the younger Alpine mountain lands, such as British Columbia and in Southern Chile and the New Zealand Alps, and in fractured and much worn plateaux of ancient rock like those of Labrador, Scotland, and Western Norway.

Fiards. - These are in a sense intermediate in structure between fiords and rias. They occur on lower coasts than fiords, and their sides are not so high and steep; otherwise they have much of the fiord character. The openings on the south-east coast of Sweden are the types of fiards.

Föhrden.-These are long, narrow, and much branched openings which penetrate eastern Jutland and the Baltic coasts of Schleswig-Holstein. The coast is a low flat one, and though these inlets have sometimes been called fiords, there is no real likeness to the deep, steep-sided openings of the true fiord character.

Lagoons or shallow coastal Lakes.-Limans are lakes formed behind the outermost deposits of deltas, where a part of the estuary has been cut off by the 
advancing deposit of river alluvium. Between the delta of the Danube and that of the Don there are numerous shallow lakes of this type, which are only accessible with difficulty from the Black Sea. Liman coasts are most readily developed in enclosed, tideless seas, though the etangs of the Landes of the Bay of Biscay are somewhat of the same nature. These shallow lakelets of the Landes coast communicate with each other by channels roughly parallel to the coast, thus forming a sort of chain of lagoons. These latter are somewhat similar to the wadden which are found behind the sand dunes of the low coast of the Netherlands (see Chapter V.). Haffs are the brackishwater estuarine lakes found at the mouths of some of the Baltic rivers and shut off from the sea by the long spits of sand (chiefly blown sand) called nehrungs. Like other lagoon-like formations on a low coast these are very shallow, being rarely more than 30 feet in depth.

Föhrden, limans, etangs, wadden, and haffs are thus all lagoon formations existing on or immediately behind, low flat coasts. They are obviously due to the action of rivers in bringing down alluvium, to winds in blowing sand into dunes along the coast, or to a combination of these.

The Dalmatian Coast.-A coast of almost unique character occurs in the eastern Adriatic. From northeast of Trieste to the mountains of Montenegro the Mesozoic rocks are thrown into a series of folds with their long extensions roughly parallel to the coast. On the seaward side there has been considerable subsidence and some fracture, and the sea penetrates the folded land of the Dinaric Alps, many transverse gaps allowing the sea to extend inland, and to penetrate longitudinally the synclinal folds of the Karst country. 
The transverse channels and longitudinal depressions isolate a great number of islands which have their general orientation parallel to the Adriatic extension. Other transverse openings and longitudinal troughs form the complex systems of valloni for which the region is famous. The best known of these rock-bound openings is the Bocche di Cattaro in the Montenegrin mountains, where three submerged longitudinal valleys are connected by transverse openings. This opening has often been described as a fiord, but that name should not be applied to it. It has little of the true fiord character.

Coasts modified by Animal or Plant Growth.-On many tropical and sub-tropical coasts the action of organisms plays an important part in the structure of the coast-line, and in its defence against marine erosion. Coral reefs and mangrove swamps are the most important of these coastal growths.

Coral Reefs.-Corals are animals of simple organisation belonging to the class Cœlenterata. Many of them secrete Calcium Carbonate from the sea water, and form a strong cylindrical or cup-shaped structure with radiating, strong divisions. Some are simple; others are compound, and a number of corals form a colony. The reef-building corals accumulate, by their continued branching and budding, large masses of solid limestone, which grow outwards and upwards, always, of course, within the sea. The building up of the enormous masses of limestone found on many coasts and in some parts of the open ocean, is no doubt assisted by the work of algæ which also secrete and deposit calcareous matter. Reef-building corals inhabit shallow sea water in warm seas, hence their operations are confined to the seas of tropical and sub-tropical regions. The seas in which these reef-builders flourish must be normally salt and 
almost free from sediment, hence coral reefs do not accumulate opposite the mouths of rivers.

So far as coastal formations are concerned, there are two not very sharply divided types of coral reefs, those which are very close to the coast, called fringing reefs, and those which are some distance away, called barrier reefs.

In many tropical seas the protective effect of coral reefs on the coast must be very great; the outside of the reef receives the full force of the attack of the waves; the water inside the reef is usually still. Ordinary marine coast-erosion must be practically non-existent on these coasts. It is obvious that the existence of a belt of calm water between the inner coast and the barrier reef will often prove of great importance in shipping. Ships often find shelter inside the barrier reef when violent storms are lashing the sea into fury outside.

It was pointed out above that reef-building corals only exist in warm seas to-day, and their resultant masses of limestone are only found in these warmer seas; but in Mesozoic times corals of reef-building type existed in temperate regions also. These coralwalls protect small islands and coasts from destruction by the waves, and probably their protective action must have been very important in Mesozoic times.

The great Australian Barrier Reef.-This is the greatest reef in the world; it extends along the northeastern coast of Australia for a distance of r200 miles, and has a width of from ro to 90 miles. There are openings through it, opposite to the mouths of rivers which bring down mud and sand from the continent. The coral polypes do not flourish in muddy water, hence there are gaps where the land-debris is borne athwart the line of the reef. 
Mangrove Swamps.-These occur on some low-lying tropical coasts. There are several species of those peculiar trees which have earned for their forests the name mangrove. They grow best between tidal limits in the tropical rainy region, where there are alternations of heavy rains and scorching sunshine. The trees send out their bent roots into the reeking, tropical slime. The fruit falling into the water sends up another shoot, and so the tangled mass grows. The waves and currents of the ocean are checked by this tangle of roots and low gnarled stems, and any drifted sediment is thus arrested. Decayed vegetation continually adds to the accumulation, producing the characteristic unhealthy and uninhabited mangrove swamp, with its stinking mire from which gases ascend, and through which crustacea crawl and in which mollusca embed themselves. The inner true land coast is thus protected by the mangrove forest, which tends to push itself outwards into the quieter areas of tropical seas.

Instability of Coasts.-Coast-lines are very unstable features. Marine erosion is for ever at work, undercutting cliffs, cutting caves, making blow holes, separating masses of rock from the mainland, and thus forming the "stacks" which are so prominent along many coasts. The destruction of cliffs is aided by the action of rain and frost. Cliffs of soft rocks such as sand and clay are rapidly destroyed, as may be seen on the Holderness coast of Yorkshire and the coast of Norfolk. The cliffs of boulder clay to the north of Blackpool have been cut away with great rapidity within the last hundred years. Even hard rocks are worn away by the ceaseless attack, especially in directions where the prevalent winds blow the waves with great violence against the land. The work is done first of all by the mechanical action of the waves themselves; these are driven with great force 


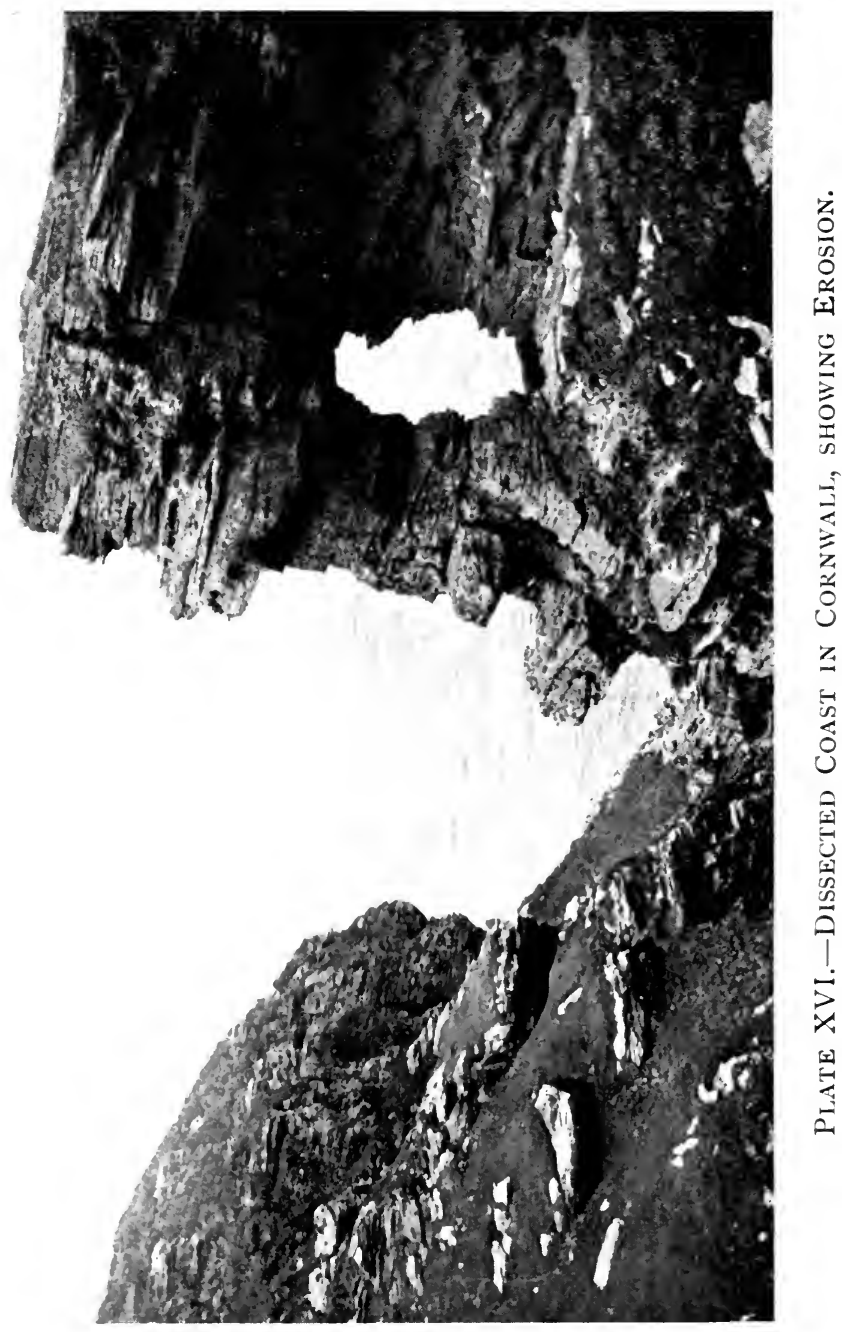




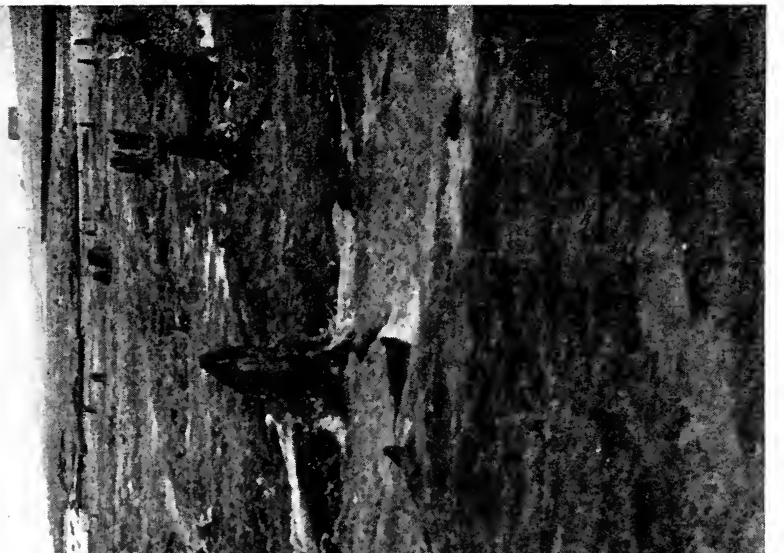

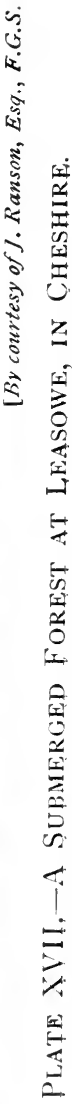

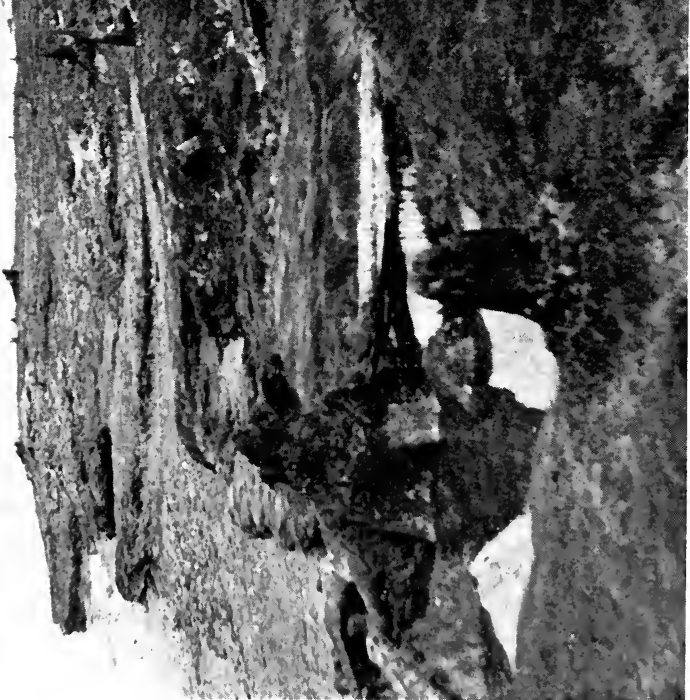


against the rocks, and their impact is so strong that large masses of rock are often dislodged. In rocks where there is much jointing the mechanical action of the waves is supplemented by the work done by compressed air; the advancing waves drive the air forward into these joints, and the alternate compression and expansion of the air assists in the erosion of the cliffs. Further, the waves hurl detached pieces of rock against the cliffs, thus using as tools the material which they have dislodged from the shore or which has beeen brought down by rivers.

The results of erosion vary with the kind of rock, the degree of exposure to waves and currents, and the time during which the rocks have been exposed to the forces at work. Professor W. M. Davis's "structure, process, stage" is well illustrated by the results of marine erosion.

The coasts of Britain are so obviously being worn away, somewhat rapidly on certain parts of the coast, that there was at one time considerable alarm, and a Royal Commission was appointed to investigate the subject. It was established that the loss which is apparent in certain parts of the coast is at least compensated by the deposition of sediment elsewhere, and that there is little or no net loss taking place at present.

In Britain and in many other maritime regions, when a limited locality is considered, the loss is not only quite apparent, but is often obviously taking place at a great rate. One of the best known examples is the Island of Heligoland, near the mouth of the Elbe. The island is at present a mere relic of what it was a thousand years ago.

Reconstruction on Coasts.-On many low coasts reconstruction or growth is in progress. In some cases it is mainly due to the action of the wind which blows 
the sand slightly farther inland from tidal beaches. Accumulations thus take place along the coast and the lands gain on the sea. In other cases the tides or other currents set in a definite direction and thus sweep along material which has been set free by coast erosion else-

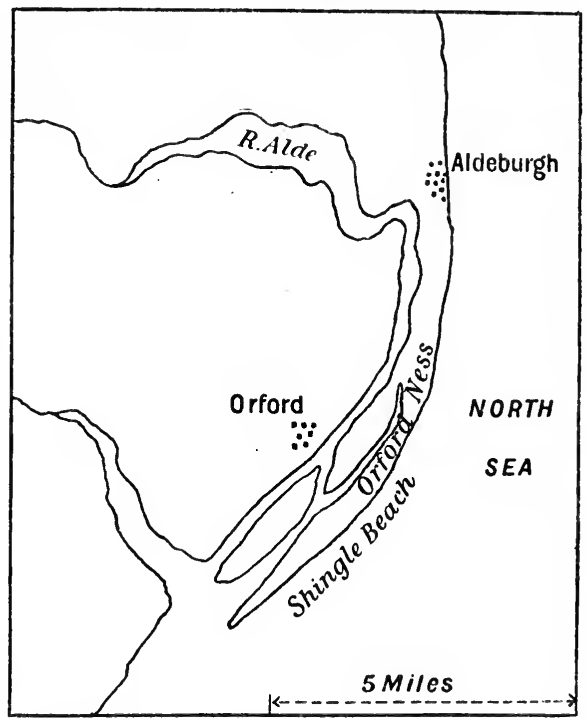

Fig 18. - The Deflection of the River Alide, in Suffolk, BY THE TIDE-DRIFTED MATERIAL FROM THE NORTH. A long Shingle Beach has been Formed, inside Which The River Alde now flows roughly parallel to the North Sea Coast.

where or brought down by river from the land. Spurn Head in south-east Yorkshire is a low sandy spit which has grown considerably, largely at the expense of the disappearing Holderness coast farther north, aided by the alluvium brought down by the Humber. It has already been mentioned that in the east of Norfolk 
there has been accumulated the drifted material from the north, and that in this way the estuaries of the sluggish Norfolk rivers have been converted into shallow lakes. Somewhat farther south is the interesting case of the river Alde, which now enters the sea much to the south of its former estuary. In the thirteenth century the river flowed past Aldeburgh. Now a long spit of land has grown to the south and the river flows parallel to the shore for quite a long distance.

River drift is brought down and distributed along shore-lines or deposited in the estuaries and bays, or deltas are pushed out into the sea. The rivers of Westmoreland and north Lancashire carry down enormous quantities of eroded material into Morecambe Bay, and in the upper part of that bay are large areas of newly-formed land. The rock-debris brought down by the Ribble and the Mersey is distributed along the shore between the two estuaries, and the land at Southport and Formby is slowly gaining seawards. Especially in non-tidal seas like the Mediterranean and Black Sea, rivers are gradually adding to their deltas and pushing them farther into the sea. The student may well read Sir Charles Lyell's classic accounts of the deltas of the Mississippi and the Ganges; the growth of river deposits and how they are pushing outwards the coastline are described in the famous Principles of Geology, with all Lyell's usual clearness.

Changes of Coast-lines due to Changes of Level.This subject was necessarily referred to in Chapter II. It may be again mentioned with special references to coastal changes. If we confine ourselves to the historic period, it is surprising how many changes of level on coast-lines have now been recorded, sometimes a rising of the land, sometimes a sinking, at least relatively rising and sinking. The Mediterranean coasts 
abound with examples. The pillars of the famous temple of Serapis near Naples show a record of alternate rising and falling of the coast in that region. The coasts of Sicily, of Southern Greece, of the Islands of the Ægean, of the west of Asia Minor, almost everywhere show signs of changes of level. In the Island of Crete some old docks are now about 30 feet above sea-level. A classic example of these coastal changes is the coast of Sweden, also referred to in Chapter II. This coast was studied by Celsius and Linnæus. Depression as well as elevation are there in progress.

Another now famous region is Alaska. There was a great earthquake in I899, and considerable changes in the coast were afterwards noticed. In Yakutat Bay, Messrs. Tarr and Martin recorded an uplift in one part of as much as 47 feet. There was depression in some parts of the neighbouring region.

Other disturbed regions where changes of coast level have been actually noticed are-the West Indies, Japan, and the north-west coast of India.

If we extend the review over the whole of the Pleistocene period, or even the time since the passing of the last phase of the glacial period, we see that coastal changes have been both great and widespread. The commonest evidence of elevation consists of raised beaches, and these are quite common on many coasts. They are of frequent occurrence on the coasts of Britain, and may be especially well studied on the Scottish coasts. On most of the north-eastern coast of Ireland there are raised beaches showing uplift of from 8 to 20 feet. In the plain of Limavady evidence of coastal elevation may be plainly seen. Raised beaches in the north of Norway indicate an elevation of many hundreds of feet within the recent period. In north-eastern North America evidence 
of elevation is seen in the neighbourhood of Boston, where uplift of only a few feet has occurred, and in Labrador, where the elevation has probably been hundreds of feet. On the other hand, depression of coast lands will obviously not be so easy to trace. Submerged forests or roots of trees below tide level are satisfactory evidence of such depression, and these are by no means uncommon. There are many, again, on different parts of the British coasts. In the North of Ireland there are, to the west of Portrush, remains of a forest which are exposed at low tide. Evidently there has been depression of the coast-line at that point. Two miles away, on the eastern side of Portrush, are raised beaches and sea caves now some distance inland, showing that on a neighbouring part of the same coast there has been recent elevation.

\section{BIBIIOGRAPHY}

(I) The Sea Coast. W. H. WheEler. Longmans \& Co.

(2) The Nature and Origin of Fiords. J. W. GREGORY.

(3) Submerged Forests. Clement Reid. Cambridge University Press.

(4) The Ocean. Sir J. Murray. Home University Library: Williams \& Norgate.

(5) The Face of the Earth. Vol. II., Seas and Coasts. E. SuEss. Translated by H. B. Sollas. Oxford Press.

This monumental work, translated into English and published in four volumes, is a storehouse of information and suggestion, on crustal movements, earth-forms, etc.

The reader may well turn, in addition to the above, to Sir C. LyelL's Principles of Geology. The last edition (2 vols.) may be borrowed from many libraries. The work is now out of print. 


\section{ECONOMIC GEOGRAPHY OF THE ROCKS}

MANY kinds of rocks and some of the contents of rocks are of use to man and of considerable importance in modern life, hence the geographer should study some of the principles connected with the occurrence of those rocks and rock-contents which are of economic value.

\section{The Uses of the Rocks themselves}

These uses are many and varied; we shall discuss them under four heads :
(a) Building stones.
(b) Ornamental stones.
(c) Paving stones and road metals.
(d) Miscellaneous uses of some rocks.

Building Stones.-In the more advanced civilisations and in thickly peopled districts the use of rocks for building purposes assumes great proportions. If hard, durable, and easily-worked rocks are readily obtained, it may be taken for granted that such will be used for houses, factories, and various other buildings. Many different kinds of rocks are used, and it is only possible to mention some of the more important.

Sandstones and Grits. - These are perhaps the most widely used of all building stones. They are plentiful, widely spread, readily obtained, cut and trimmed without very much difficulty, and they are, as a rule, durable. In the British Isles, sandstones from 
many geological systems are used. The Torridon Sandstone of the north-west of Scotland is freely used in that part of the northern Highlands where it occurs. Grits of Cambrian age are used in North Wales. Ordovician and Silurian grits are also used in Wales. The Old Red Sandstone yields excellent building stone in the Malvern Hills and in Herefordshire. Tintern Abbey and Chepstow Castle are examples of old buildings in which the rock has been used; in both cases the sandstone has suffered considerably from the long continued weathering. It is also quarried in many parts of Scotland. Hugh Miller, the famous Scottish stonemason geologist, worked for a long time in the sandstone quarries at Cromarty and the north side of the Moray Firth. In his My Schools and Schoolmasters he says: "Getting a suit of strong moleskin clothes, and a pair of heavy hob-nailed shoes, I only waited for the breaking up of the winter frosts to begin work in the Cromarty quarries. . . . The quarry in which I commenced my life of labour was a sandstone one, and exhibited in the section of the furze-covered bank which it presented, a bar of deep, red stone. . . . The deep, red stone formed part of an upper member of the Lower Old Red Sandstone."

The sandstones and grits of the Carboniferous system are very widely used as building stones, both the rather coarse, hard grits from the Millstone Grit formation, and the finer-grained sandstones from the Coal Measures. Some of the more famous stones and localities are the Pennant Grit of the Forest of Dean, the Darley Dale sandstone of Bakewell, the sandstone of Glossop, the sandstones of Brighouse, Queensbury, and Bingley, in the West Riding, the sandstones of Rochdale, Bacup, Burnley and Nelson, the grits of the district near Colne, Bramley near Leeds, and the Craigleith Sandstone 
near Edinburgh. The abundance of these Carboniferous sandstones has been a great factor in the economic life of many parts of the Pennines, where the commodious stone-built houses of the working classes are well adapted to the somewhat stern climate of the hills.

The New Red Sandstone (Permian and Trias) yields good building stone near Nottingham and Derby, at Mansfield, at Runcorn, and near Birkenhead, at Penrith in the Eden Valley, at Dumfries, and at Elgin in North Britain. As a rule the New Red Sandstone is easily quarried and worked, but it is not so durable as the sandstones of the Carboniferous. A very good example of a New Red Sandstone is Furness Abbey, near Barrow. The stone, which came from St. Bees, is now very considerably weathered. Sandstones newer than the Trias are not very widely used in Britain, but in other parts of the world there are many good building-stones of much newer age. In the Tertiary basin of Paris there is a sandstone which has been very largely used for building, and a similar rock of Tertiary age has been used in Carolina, U.S.A. A sandstone of recent age, formed by the consolidation of the sand of sand-dunes by sea water, has been much used in Cape Town.

North American Building Stones.-Cambrian sandstones, from the Adirondack Hills of New York State, furnish excellent building stone; their reddish brown colour, evenness of grain, and ready accessibility have made them favourite stones for the purpose. In the Atlantic coast cities, Ordovician and Silurian sandstones have been extensively used. These are quarried in many parts of the Appalachian mountain system. Suitable Mesozoic and even Cainozoic sandstones abound in the Western States, providing an inexhaustible supply of good building stone.

Limestones. - These rocks are also frequently used 
for building purposes. The Oolitic limestones of the British Jurassic system furnish some of the most valuable and most famous building stones. The freestones $^{1}$ of Portland, Bath, Painswick (in the Cotswolds), Ketton, Stamford, and Ancaster are all famous examples of Oolitic limestone used for building. St. Paul's Cathedral is a good example of Portland stone. Similar Oolitic limestones are worked at Caen in Normandy. Canterbury Cathedral and Westminster Abbey are built from the cream-coloured Caenstone.

The Magnesian Limestone, which occurs in the Permian system, on the eastern side of the Pennines, has been largely quarried for building purposes near Doncaster, Mansfield, and Bolsover. The Houses of Parliament in London are built chiefly of this stone from Bolsover. Many of the famous country seats of the Trent region are built of it, and it lasts very well in the purer air of the country. Castles built by William the Conqueror have lasted well, as has also York Minster; but the acid-tainted air of London is slowly but surely destroying it, and much of the fine chiselling of the Houses of Parliament now presents but a sorry appearance. $^{2}$ The life of a building stone, and consequently its suitability for use, depends not only on its own nature, but on the district in which it is to be used.

A fresh-water limestone, formed of fresh-water shells and the nucules of calcareous algæ, has long been worked at Binstead in the Isle of Wight. It belongs to the Bembridge beds in the Oligocene system. Many of the older churches of Hampshire and the Isle of

${ }^{1}$ A freestone is one which can be worked almost equally well in all directions.

${ }^{2}$ The front of the Museum of Practical Geology in Jermyn Street is Magnesian Limestone, and this has stood well; it may be to some extent a case of good selection of the stone. 
Wight are built of it, and it was long known as the Quar Abbey Stone.

The nummulitic limestone of Eocene age is well known to visitors to the Great Pyramids of Egypt. The disc-like forms of these large foraminiferæ are among the best-known curios of the visitor to Egypt.

In Florida limestones formed of accumulations of living species of shells have been used in the construction of buildings.

Slate.-This member of the argillaceous group of sedimentary rocks is of considerable importance in the building industry. Slates are usually found in the older systems, and in localities where much lateral pressure due to mountain-folding has taken place.

Famous British localities are Llanberis and Penrhyn in the Cambrian of North Wales, Festiniog in the Ordovician of North Wales, in the Devonian rocks of Devonshire, and in the Archæan of Argyllshire. The green slates of Borrowdale and other parts of the Lake District are beds of fine-grained volcanic ash which have had cleavage developed by pressure so that they split into thin regular layers.

Clays and Shales.-These are used for making bricks. The London clay has provided bricks for the building of a great part of London; the Gault clay of the clay vale and the Weald and the Lias clays of the Midlands are also used in brick-making. The shales of the Coal Measures are ground by machinery into a paste and excellent bricks are made from the "clay" thus produced. Accrington, in Lancashire, is famous for bricks made from these coal-measure shales. Most of the houses in many of our great cities are built of bricks; the importance of large deposits of clay and shale is therefore obvious.

The clays which frequently occur under the coal- 
seams of the Coal Measures (and which are known as " under-clays") are almost free from alkalies. In consequence these clays are sufficiently infusible on heating to be made into firebricks for the linings of furnaces.

Igneous Rocks. - These are used for ordinary buildings only in the neighbourhood of their occurrence. For example, the grey Aberdeen granite is used in Aberdeen and the immediate district. Granite from various localities is imported into towns for the facing of important buildings. Thus in many London streets one may see shop-fronts, banks, etc., faced with Shap granite, the large crystals of pink felspar in which rock immediately arrest the attention. The pillars in front of St. Pancras Station are made of this granite. So also the large white crystals of felspar in the grey granite of Dartmoor may be frequently seen in London and other southern towns. London Bridge is a good example. Granite from Aberdeen is, of course, very frequently seen ; it is especially common in many parts of the city of London. Granite from the Mourne mountains may be seen in the steps of the Albert Memorial in Hyde Park. A famous plutonic rock allied to granite has been imported into Britain from Laurvig on Christiana Fiord. When polished its large crystals of soda-felspar impart to this rock a striking appearance. This "Laurvigite" has been largely used not only in London but in many a provincial town. Syenite and diorite are also frequently used. Cleopatra's Needle is frequently called a syenite; it is more accurately described as a hornblende-granite. The more basic rocks are less durable and very heavy; hence gabbros are not used so frequently.

Rhyolites and trachytes are frequently used as building stones because they are relatively light and 
durable; basalt has too splintery a fracture to be readily worked, so that its use is limited and local. Basaltic columns have, however, been widely used in building piers, breakwaters, and sea-walls. For example, basalt from the banks of the Rhine, showing good hexagonal columnar structure, was used in building the central sea-wall at Blackpool. Many of the sea-walls and artificial levees in Holland have been largely built of the same lava columns. Italian cities are largely built of tuff, that is, solidified volcanic ash.

Metamorphic Rocks.-Schists and gneiss are frequently used as building stones. Gneiss is quite as good as granite as a rule, though it is apt to be more variable in appearance. Finely laminated schists are used in many mountain regions; unless they are very fine grained they are apt to flake somewhat along the foliæ of mica, and are thus not so suitable as gneiss. The quarrymen of Switzerland call the more evengrained schists "Granit," and these schists' are widely used there as building stones.

We have chiefly considered houses, churches, factories, public buildings, etc. In addition to these we may mention docks, breakwaters, fortifications; these are often built of the harder igneous and metamorphic rocks, the hard resistant granites being the commonest of these stones.

Ornamental Stones.-There is no absolutely clear division between these and building stones; the stones used in facing many important buildings, and in making the pillars of banks, hotels, etc., coming partly under both heads. The chief requisite for an ornamental stone is that it is capable of taking a high polish ; many show in addition a beautiful play of colours. In general they are obtained from the igneous and metamorphic rocks, or from sedimentary rocks which have been at least 
considerably altered. They are, therefore, characteristic of mountain regions. Two important kinds, marble and serpentine, may be considered here.

Marble.-This is a calcareous rock capable of taking a high polish. The name sometimes connotes a metamorphic rock, but in trade it signifies any calcareous rock (often including even a serpentine) capable of being polished. Many of the British " marbles" are simply fossiliferous limestones, in which such fossils as crinoids and corals make pleasing contrasts with the ground mass when the rock is polished. A fine marble from Tiree in the Inner Hebrides is of Archæan age. There is a Cambrian marble in Skye. Devonian limestones from Torquay contain corals and polish well; similar rocks of Devonian age occur in the Ardennes and Eifel. The infiltration of iron has sometimes produced thin red streaks, and these show up well when the rock is polished; a good example is the Devonian limestone of Plymouth. There are many Carboniferous limestones which take a good polish and to which the name " marble" is then applied. The red marble of Cork and the black marble of Kilkenny; the Derbyshire marble of Wirksworth; the Dent marble of the West Riding of Yorkshire, and the fine coral limestone of Frosterley in Durham are British Carboniferous " marbles." Rocks of the same age which take a high polish are common in Southern Belgium. The "Petit Granit " of the valley of the Meuse is a dark-coloured Carboniferous limestone with corals showing up white on the dark ground. There are many similar Carboniferous " marbles" in the United States.

The "Purbeck Marble" of Swanage consists chiefly of shells of Paludina, a fresh-water gasteropod. This rock takes a fairly high polish and has been used by way of contrast with the white and cream-coloured 
stones for the columns of some of the cathedrals and churches of the South of England.

Marbles, both as understood, above and of the true metamorphic type, are common in North America. Fine white statuary marble comes from Rutland, Vermont. Marbles are, in fact, found in scores of places in the eastern mountain system and in the old rocks of the Laurentian region. They include various kinds, red marbles, black marbles, white statuary marbles, and bluish varieties. Marbles are also found in the western mountains in Colorado and California.

Some of the famous marbles of antiquity and of the Middle Ages have come from Italy and Greece. The famous Parian marbles from the Island of Paros and turquoise-blue marbles from Seravezza, Italy, are examples. "Mandelato" shows yellow spots on a red ground and is found in Italy, and " Predazzite" is found in Predazzo in the Tyrol. These are only examples selected from a great number of occurrences.

Serpentine.-This is a rock produced by the alteration of basic and ultra-basic igneous rocks. It is tough, soft, and compact and of very variable colour, showing shades of yellow, green, and deep red, with streaks and veins and mottlings of various colours. The name serpentine was given because of its supposed similarity to the markings on a serpent.

There are four chief British localities : the Lizard district in Cornwall, Valley near Holyhead in Anglesea, near Ballantrae in south-west Scotland, and Portsoy in Banffshire. A serpentinous "marble" occurs in Connemara, and is commonly made into charms and ornaments. In consequence of its liability to attack by acids, serpentine is little used for outside work.

Paving Stones and Road Metals.-The provision of paving-stones and setts for the streets of towns is now 
an important problem, and the nature and source of some of the stones deserve the attention of the student of geography. Hardness, durability, and reasonable lightness are the obvious desiderata in paving stones. The last named quality may be illustrated by concrete examples which will serve as illustrations of general principles. Some quarries were formerly worked in gabbro at Llanfaglan in Carnarvonshire. The writer once visited these quarries to study the rock from the geological point of view. A local farmer was much interested, and pointed out that the quarries had to be closed because buyers, who usually buy the rock by the ton, could get much larger bulk in other rocks for the same money. Gabbro, of course, has a much higher specific gravity than granite, hence there is not so great a cubical content in a ton of the rock. Another example was as follows: A north-east Lancashire town experimented in the use of a German vesicular trachyte as a paving stone. As the local surveyor pointed out, the vesicular character of the rock made it very light, and a ton contained a much larger number of averagesized paving stones than usual. It would therefore be a cheap rock to use. Unfortunately, it did not wear well under the heavy traffic of a Lancashire manufacturing town, and much of it had to be taken up and replaced by a more compact rock; the experiment was a failure.

The examples quoted are from igneous rocks, the one a plutonic, the other a volcanic rock. Igneous rocks now supply the bulk of paving stones. Some famous localities are: The granite of Criffel and Dalbeattie in south-west Scotland, the compact granites of Charnwood Forest in Leicestershire, the diorite of Penmaenmawr in North Wales, the dolerite of Pwllheli, North Wales, the Cleveland Dyke of North Yorkshire, and the 
Whin Sill of Teesdale and Weardale. There are very many other igneous rocks in other localities.

Most of these rocks are also broken up for road metal. Other famous road metals are the igneous rocks of the Lake District, especially Threlkeld, near Keswick. "Rowley Rag" is a basalt from South Staffordshire, which has been very largely used in the Midland and Southern Counties.

A quartzite rock from the Cambrian of the low hills near Nuneaton is used in large quantities for road metal in the English Midland Counties. The chief quarries are on Hartshill.

Paving stones and setts are frequently made from the harder beds of the Millstone Grit; especially are these used in the towns of Lancashire and the West Riding, where carriage for the stone is not heavy because of the short distance. Rossendale, Whalley, and Barnoldswick are localities where Millstone Grit paving stones and setts are obtained. Hard flagstones, frequently used in northern towns, are obtained from Rossendale and from the moorlands in the neighbourhood of Halifax and Bradford.

The hard, dark-coloured limestone of the lower Carboniferous is frequently used for macadamised roads in the Pennines, where that type of rock is plentiful and easily obtained.

Some Miscellaneous Uses of Rocks.-Limestone is of very great importance in many processes. Very large quantities are used in iron smelting, where it is added to the ore and the coke in the furnace so as to form a slag with the siliceous impurities in the ore. For iron ores containing phosphorus, dolomitic limestone (that is, composed of magnesium and calcium carbonates) is used. Limestone is also needed in the manufacture of sodium carbonate in the old Leblanc process, which is still 
widely used. It has also many uses as lime, which is formed by roasting or "burning " limestone in a limekiln. There is a big demand for lime to be used as manure on the land. It is also largely used in the preparation of skins for the tanning processes in leather manufacture; for absorbing impurities in coal-gas manufacture; and in the manufacture of caustic soda from sodium carbonate or common soda. Finally, it is used in making cement, mortar, etc., for building. It will thus be seen that lime is a most important compound, and that the presence of limestone is one of the factors which determine the possibility of many trade processes.

Millstone Grit.-The name was originally given to this formation because millstones for grinding were made of its coarse, hard sandstones. In the old cornmills of the Pennine valleys, where the locally grown oats were ground into oatmeal, the grindstones were made of Millstone Grit. These have long since passed out of use, except occasionally, but recently grindstones of Millstone Grit rock have been in demand for quite another purpose. In a quarry at Colne near Nelson in north-east Lancashire there are at the present time numbers of large, round, that is, disc-shaped stones, some four or five feet in diameter and about two feet six inches in thickness. These are for export to eastern Canada, where they are to be used for grinding timber into wood pulp. A quarry in Millstone Grit near Keighley in the West Riding of Yorkshire has been recently acquired by a North American lumbering company for the same purpose. It is not apparent to the writer why suitable stone cannot be obtained nearer the lumbering region; it seems a long distance to take grindstones across the Atlantic. It is, however, a good example of the interdependence and international character of industries in modern times. 
Another mention of Millstone Grit, and some of the similar grits of the Coal Measures, máy be not out of place. Sheffield has long been noted for its cutlery. One factor which has made for its success in that industry has been the presence and abundance in the neighbourhood of grit-rock suitable for grindstones. In the earlier days of the development of cutlery manufacture, the advantage derived from suitable stone was emphasised by the occurrence of numerous streams, well fed by the abundant Pennine rains, which were used to drive the cutlers' grindstones.

Rock Salts.-In all the continents there are, in the present geological epoch, regions of internal or closed drainage, where the rivers do not reach the ocean, but pour their waters into salt lakes, where, on the whole, evaporation keeps pace with water supply. The soluble salts which are dissolved in the water of all rivers thus accumulate until the saturation-limit is passed and precipitation occurs. These internal-drainage lakes are, as may be expected, variable in area according to the season, or from year to year according to variation in rainfall. In the shallower, exterior parts of such salt lakes, precipitation of salts occurs regularly and large supplies are obtained from such sources. The Kara Borghaz (the eastern gulf of the Caspian Sea), for example, yields large quantities of salt. There is a regular current from the main body of the Caspian into that gulf, the bottom of which is encrusted with a layer of salt. A good deal of salt is obtained from the great Salt Lake in Utah, U.S.A. Lesser salt lakes, such as the Sea of Aral, the Dead Sea, and scores of others, yield either common salt (sodium chloride) or that salt mixed with others.

The water of the ocean contains, on an average, about three per cent. of dissolved salts ; many of these 
inland salt lakes contain much larger proportions. The Great Salt Lake of Utah, U.S.A., contains I8 per cent.; the Dead Sea of Palestine, 24 per cent.; Lake Van in the Armenian Highlands, 33 per cent.

The different salts vary in proportion as magnesium salts are more soluble than sodium salts, and when the latter have already crystallised out the relative proportions of the magnesium chloride will be increased. Great Salt Lake contains eight times as much sodium chloride as magnesium chloride, but the Dead Sea has twice as much magnesium chloride as sodium chloride. Lake Van contains sodium sulphate and sodium carbonate. The surface of this remarkable lake has been rising in level for some years; it is suspected that a lava flow is accountable for the stoppage of the normal overflow of one part of the lake.

It will be clear that deposits of common salt or other salts will be formed in the strata of these regions, and that they will alternate with sands and marls formed in these internal drainage lakes. We may therefore expect beds of rock salt to be found in those geological systems where similar conditions have held, and such salt deposits are quite common. In New York State there occur salt beds in Silurian strata; these are beds of rock salt and gypsum which reach as much as 300 feet in thickness. Carboniferous salt deposits are found in Michigan. The lower beds of the famous salt deposits of Stassfurt in Prussia are Permian. One boring has passed through varied salt deposits well over 3000 feet in thickness. The salts found are sodium, potassium and magnesium chlorides, and gypsum. The salt beds of the deep boring of Sperenberg, north of Berlin, are of Permian age. The bore-hole passed through about 4000 feet of salt deposits.

The salt deposits of the British Isles are in the Triassic 
rocks, as are some of the other salt beds of the Continent. There are Mesozoic salts in Texas and the other Southern States. Tertiary salts are also found in the same region, one boring in Louisiana passing through I80o feet of salts. The most famous Tertiary salt rocks are those of Wieliczska, near Cracow, in Poland. These have been worked for ages, and the occupation of these salt mines by the Austrians in I770 was one of the first important steps in that partition of Poland which has brought so much trouble to eastern and central Europe.

These immense salt deposits are of great geographical importance not only for the immediate salts obtained, but for the industries dependent upon them. Not only are these salts used in foods and for agriculture, but they form the raw material of many chemical manufactures. Consequently such manufactures are found in, or near, large salt deposits. The great chemical industry of the Mersey is located between the salt supplies of Cheshire and the rich coal supplies of the South Lancashire coal-field, and where the Mersey, the Ship Canal, and the smaller canals offer ready facilities for inter-carriage and for import and export. The Stassfurt salt deposits have been the foundation of the flourishing chemical industries of Saxony and the adjoining parts of Prussia.

Finally, in this connection, we may notice a modern exceptional deposit, a rock in the true sense, which occurs in the desert region of western South America. In the desert of Atacama in Peru is a deposit, chiefly of sodium nitrate $\left(\mathrm{NaNO}_{3}\right)$, occurring on the mountains up to heights of 5000 feet. This surface deposit of such a highly soluble salt is, of course, only possible in a rainless region. The beds of " caliche," as the impure salt is called, contain in addition iodides and potassium salts. The origin of these extraordinary deposits has not yet 
been fully explained. Perhaps they are due to the decomposition of immense masses of sea-weeds, left to decay and alteration after the uplift of an old sea bottom on which had grown vast quantities of such weeds. Other explanations have, however, been put forward. These nitrate deposits, with their somewhat subsidiary iodides and potash salts are now important sources of nitric acid and of iodine, as well as potassium compounds.

\section{Rocks as Fuels}

The formation of rocks from decayed vegetation was referred to in Chapter II. A full account of the origin of peat and coal would take us too far into the science of geology. As students of geography we may here glance at the economic aspect of the occurrence of these vegetable deposits.

Peat.-This occurs in large quantities in cool, temperate regions both on the wider moorlands and in the marshy lowlands. Typical regions are the Southern Uplands of Scotland, the moors of the Midland Valley of Scotland, the broad grit moors of the Pennines, large areas in the Central Plain of Ireland, the Mountains of the North and West of Ireland, and the Low Countries, i.e. parts of Belgium, Holland, and Northern Germany. Peat is cut and dried and is used for fuel, as litter for cattle and horses, and occasionally for the generation of ammonia by destructive distillation. Compressed peat in the form of briquettes has been exported from Holland and North-west Germany in large quantities. In the poorer parts of Ireland peat is the chief, almost the only, fuel used in the homes.

Coal. - This valuable fuel occurs in layers or seams, which are often remarkably regular in thickness over wicle areas. These seams vary from a few inches to many feet in thickness. A seam is usually worth working 
if it is two feet or more in thickness and not very difficult of access. Seams which are actually worked vary considerably in thickness, as may be expected. Many famous British seams are from three feet to six feet thick. The famous Dudley Main seam in the South Staffordshire coal-field has a thickness of twelve feet in places.

Coal-seams only form a very small fraction of the strata in which they occur. In the Burnley coal-field, in a generalised section of about 2360 feet of coal measures, there are twelve workable coal-seams of a total thickness of a little over 30 feet. The rest of the Coal Measures are shales, sandstones, fireclays, and very thin coal seams, the total coals, workable and unworkable, being about 54 feet.

In the British Isles there are few workable coal-seams in strata other than the Carboniferous system; the exceptions are a variable seam in the Jurassic system at Whitby, of rather poor coal, and a seam in the Jurassic of Brora in Sutherlandshire. These seams are of little value economically; they are of considerable geological interest, however.

Workable coals occur in geological systems from the Devonian to the Tertiary (see Chapter I.). The oldest real coal-seams known are found in Bear Island in the Arctic regions. A seam over three feet in thickness occurs there in the Devonian strata.

Coals of Carboniferous age are widespread and include the richest coal deposits in the world. They occur in Europe, Asia, and North America. Coals of upper Carboniferous and Permian age are found in Australia, India, South Africa, Argentina, and Chile, that is, in the Southern Hemisphere chiefly. They are a little newer than the chief coal-fields of the Northern Hemisphere.

Most of the small coal-fields of Central France are of 
Permian age, as are those of Saarbrücken in Lorraine, and those near Dresden and in Bohemia.

Triassic coals are found in Virginia, U.S.A., and in Japan; and Jurassic coals occur in Britain as already mentioned, and at Fünfkirchen in the Danube-Save region of south-west Hungary. Cretaceous coals are worked in Washington, U.S.A., in Alaska, in New Zealand, and Japan.

Tertiary coals are worked in Germany, Hungary, Japan, and the north-west region of the United States. Rich coalfields of this age have been found in Spitzbergen.

The more recent coals are usually of the variety known as lignite or brown coal. These coals are less compact than the older coals, and usually still retain some of the original vegetable structure. They are not so valuable as the coals of Carboniferous and Permian times.

A map of the chief coal-fields of the world is given on page I74, from which it will be seen how well supplied are Europe, North America, and Eastern Asia.

The different varieties of coal are of great importance. The usual classification of coals as bituminous, cannel, and anthracite may not fully satisfy modern science, but from an economic point of view it is a convenient one.

Bituminous Coal is the general name given to the coal burnt in our ordinary grates; it is stratified, splits readily along the bedding planes, soils the fingers on handling, partly melts in the grate in burning, and gives out gas and pitchy or bituminous matter. It is usually somewhat shiny in appearance, especially along the bedding planes.

Cannel Coal is not so plainly stratified; it breaks with a splintery, irregular fracture; is dull, black, and hard, and soils the fingers very little. It burns with a crackling noise, and when heated gives off a good deal of gas. When luminous coal-gas was more in de- 


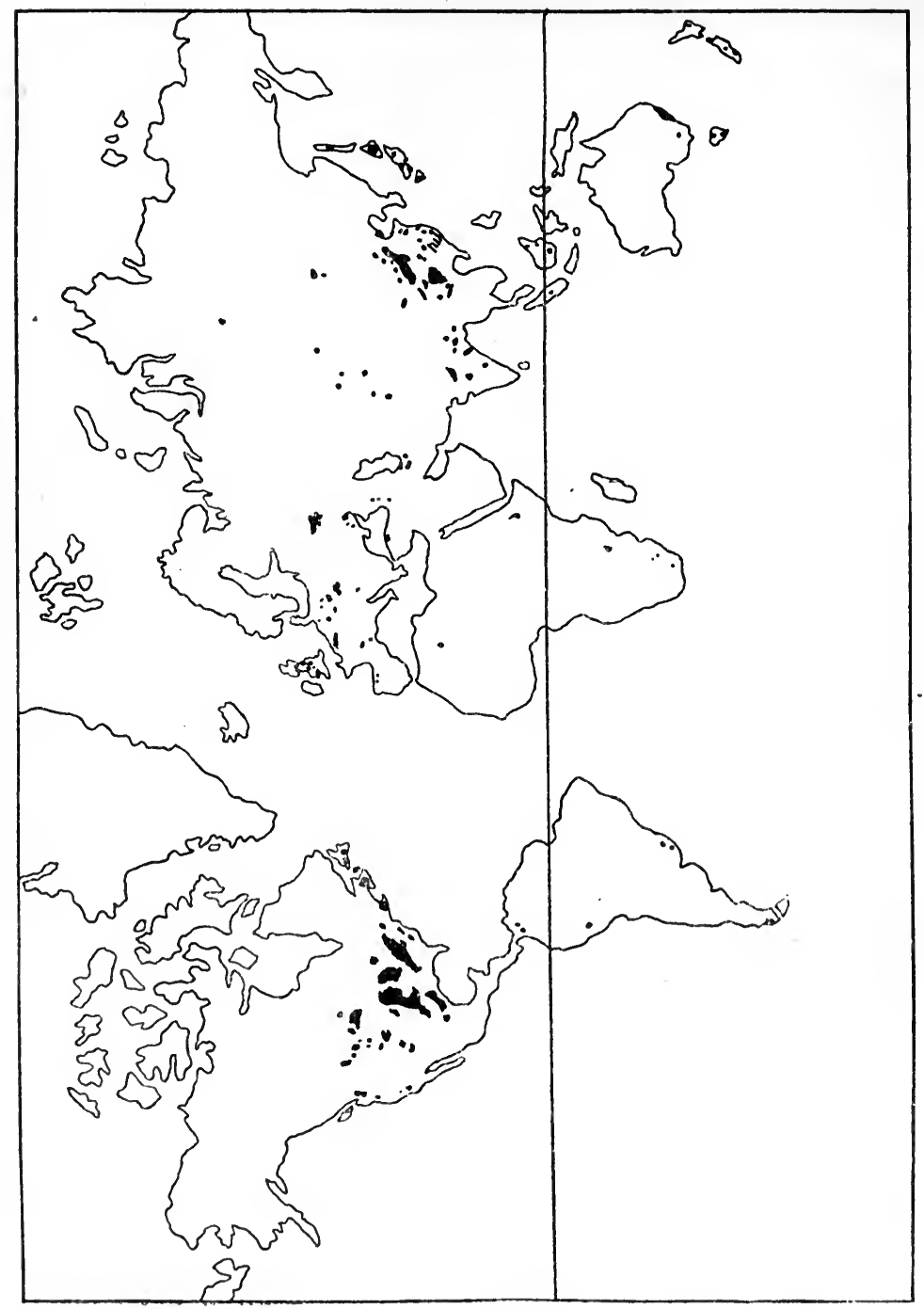

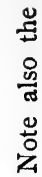

究

点

因

匍

幽㟧

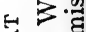

¿ 폰

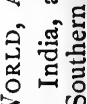

$\forall$ E

由

覀

占 芑

ڤ 己

国

运.

它

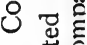

월

出

1.

요

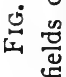

.뮴

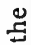

ัㅜㄴ 
mand, large quantities of cannel coal were used in the gasworks of the country.

Anthracite is an important modification of coal occurring where there has been much folding of the strata. It is probably not due to compression merely, but owes its characteristic properties in some measure to original peculiarities of composition. It is the hardest kind of coal, has a shiny appearance, burns with comparative difficulty, emitting little or no smoke, and leaving very little ash. It is of great value for warships which burn coal, as no trail of dense smoke is left behind. It is now largely used in certain kinds of slow combustion stoves. The supplies of good anthracite are limited to certain regions; South Wales, Pennsylvania, and Japan being among the best known. There has been considerable discussion in recent years as to the advisability of Britain continuing to export any of its anthracite. The possession of large supplies of this valuable kind of coal is certainly a great asset to Britain. The discussion of the question mentioned belongs rather to politics than to geography.

The question of the duration of our coal supplies has exercised the minds of statesmen, mining experts, and geologists. This is of such importance that two Royal Commissions have sat and taken evidence within the last half-century. On the whole, there is, perhaps, less alarm now than there was some years ago, because coal-seams are now so largely worked by boring through overlying strata such as the New Red Sandstone. In the South Yorkshire coal-field the actual mining field now extends far beyond the limits of the coal-field as marked on a geological map. Large supplies of coal are now obtained from these " buried coal-fields." The limit of such operations is reached when the dip of the coal-seams carries them down to such a depth that 
difficulties of ventilation and expense of lifting the coal become too great, and the working does not pay. Coalseams are now worked at a much greater depth than formerly.

The coal output of the world now amoun ts to above Iooo million tons per annum. In the year I9I2 the United States of America contributed about 42 per cent. of this output, Great Britain about 26 per cent., Germany ${ }_{5} 5$ per cent., and France 4 per cent.

The . British Isles export nearly $£ 40,000$, 00o worth of coal and coke per annum. The total value of the coal obtained was well over $f_{\mathrm{II}} \mathrm{I0}, 000,000$. Over a million persons are employed in the British coal mines in normal times.

In the closing part of this chapter brief mention may be made of the remarkable influence of coal supplies on the distribution of population. Coal is so largely used, not only for fuel in the ordinary sense as a source of heat energy but for gas manufacture, and for the production of coke for smelting, that abundance of it may be reckoned as the first necessity of a busy industrial region. In the countries where manufactures employ large numbers of people the thickly peopled regions are very often in or near coal-fields. The student should compare a map of the distribution of the population in England in say r7oo, with the distribution in I900, and then place the map showing the latter side by side with a map of the coal-fields; the correspondence of the two maps is striking. The distribution of coal supplies will come up again in connection with the smelting of metals.

There is some possibility that the pre-eminence of coal may be challenged in the future ; as coal becomes dearer, manufacturers are compelled to look out for other sources of energy, and electricity generated from 


\section{ECONOMIC GEOGRAPHY OF THE ROCKS $\quad 177$}

waterfalls in mountain regions is being more and more used. There may possibly be a new distribution of great industrial regions in the future; the dominant factor may be abundance of water-power and coal may take a second place. That phase of industrialism is not yet, however.

\section{BIBLIOGRAPHY}

See end of Chapter X. 


\section{CHAPTER X \\ ECONOMIC GEOGRAPHY OF THE ROCKS (Conta. \\ Rock Contents}

IN the preceding chapter the uses of the rocks themselves were discussed; we now turn to some of those substances of economic importance which are obtained from the rocks. Rocks as fuel were considered in the latter part of the chapter; we will commence this chapter by some study of those fuels which occur as occasional constituents of certain rocks.

Petroleum and related Substances.-From the rocks of many parts of the world gaseous, liquid, or solid substances which will burn readily are obtained. They are practically all compounds of carbon and hydrogen, and are therefore generally spoken of as hydrocarbons. They are found in sedimentary rocks of all ages from Cambrian to Recent, but the mode of origin is still a matter of some uncertainty. When a boring is put down into strata containing these hydrocarbons, gases are often set free and come rushing out with considerable force. Liquid hydrocarbons have also been forced up with such violence that the boring apparatus has been hurled away.

Petroleum now forms one of the most important supplies of fuel; the increased use in motor-cars, aeroplanes, and for men-of-war and in other ways, has 
made a big demand, especially for the liquid fuel. In some districts the gaseous and liquid hydrocarbons are used in the place of coal, coke, and coal-gas ; for example, in gas engines and for the smelting of iron. Large quantities of these rock-oils are also used for the extraction and preparation of different kinds of fats. Both animal and vegetable fats and oils are readily soluble in the hydrocarbon oils.

The chief regions from which petroleum is obtained are the United States, Canada, Mexico, southeastern Russia, Galicia, Rumania, Persia, Burma, Borneo, and Japan. The oil-fields of the United States are the richest in the world yet known, and occur in areas of Palæozoic rocks in the eastern region: in Pennsylvania, New York, Ohio, and Indiana. The rich fields of western Pennsylvania and New York have given rise to a marvellous development of industries of many kinds in which large supplies of fuel are necessary. Much petroleum is used in the immense iron industry of Pittsburg and district. Petroleum is obtained from Mesozoic strata in Wyoming and Colorado, and from Cainozoic rocks in California.

The yield of petroleum and natural gas in North America may be gathered from such facts as the following: One single boring in Ohio has been known to yield over $17,000,000$ cubic feet of gas per day. Natural gas consumed in industries and for lighting and warming is valued at about $£ 5,000,000$ per annum in the United States alone. Over $8,000,000$ gallons of oil are now produced in an average year in that country alone. Of the world's supply in I9I2, the United States produced 63 per cent., Russia I9 per cent., Galicia 4 per cent., the Dutch East Indies $3 \frac{1}{2}$ per cent., and Rumania 3 per cent.

The Russian Oil-field. - The great Russian oil-field 
lies on both sides of the Caucasus mountains, the richest part being in the peninsula of Aspheron where those mountains extend into the Caspian Sea. Baku is the "centre" of the industry. Burning oils have been known there for hundreds of years, but the great development of the oil-fields has been of quite recent growth. Many of the wells are "free-flowing," that is, no "pumping" is necessary. Single wells have been known to yield more than I,000,000 gallons of oil per day for many days together. A pipe over I40 miles long has been laid down to convey the oil from Baku to the special tanks.

The Caucasian oil-region extends into Persia and Turkestan. The recent action of the British Government in acquiring an interest in the Persian oil-fields has brought this region into prominence.

The Galician and Rumanian oil-fields are similarly related to the Carpathian fold-mountains, as the Russian oil-wells are to the Caucasus. The most productive area is on the north-east of the great curve of the mountains from Kolomea to Jaslo. Other rich wells are in the Kolozsvar district in Transylvania, and in the Ploesti district on the opposite side of the mountains in Rumania.

Solid hydrocarbons are obtained from the same oilregions as the liquid and gaseous compounds, and from a few other places where the latter are not obtained in any great quantity. The solid products are obtained in the arts as residues from the fractional distillation of the oils, and in nature they are probably the result of evaporation of the more volatile portions of the naturally occurring hydrocarbons. A series can be drawn up from the most volatile hydrocarbons of the paraffin and olefine series of the chemist to the most solid asphaltum. Paraffin scale and vaseline are well known from the United States ; 
and from the Caucasus is obtained solid bitumen, a hydrocarbon mixture which is now widely used. Asphalt or asphaltum has long been known from Switzerland, where it is obtained from the Val de Travers. The most famous occurrence of asphalt to-day is the "Pitch" Lake" in the Isle of Trinidad, a lake of semi-molten, hot pitch, half a mile in diameter and of unknown depth.

Hydrocarbons from Oil-Shales. - In the Carboniferous system of the Midland valley of Scotland there occur . shales known as oil-shales or bituminous shales. They are worked in Linlithgow, Midlothian, and West Fife, and to a lesser degree in the coal-fields farther west. The shales are heated in retorts, and the oils distilled over and condensed in receivers. The products of lower boiling-point, which, of course, remain liquid at ordinary temperatures, are known as Paraffin Oil; their general composition is much the same as the petroleums from the natural oil-wells, and they are used for the same purposes. The solids, which are left after evaporation of the more volatile portions, are usually called simply Paraffin. Candles are made from these solid Paraffins; and there are many other uses for them. In New.South Wales similar bituminous shales yield the kerosene which is used for lighting many a settler's home in Australia.

Metals and Ores of Metals in the Rocks

The distribution and mode of occurrence of metals is of great importance in the study of economic geography. Metals are of such great importance in modern life, and so many of man's activities depend directly upon them, that their distribution exercises a very great influence upon the industries of a country and upon the distribution of population. The subject may be 
illustrated by reference to the more important and better known metals, such as gold, silver, copper, lead, zinc, tin, and iron; though, of course, many other metals are of great importance to man, and the importance of some of the rarer metals (such as tungsten, for example) seems to be increasing rapidly.

It is obvious that the occurrence of rich iron ores in conjunction with fuel to smelt them not far away will probably lead to a great concentration of population, and to the establishment of varied steel industries; examples of this are seen in Central Scotland, South Staffordshire, Westphalia, and the Pittsburg region in the Appalachians.

The discovery of gold has brought about sudden and extensive migrations, and eventually has led to the settled colonisation of the gold regions; the well-known "gold-fever" of California in I848-50 and of Australia in $\mathrm{I} 85 \mathrm{I}-2$ led to a great rush of emigrants to those countries. Many of those failed as gold seekers, but settled as agriculturists or as traders; and some of those who made fortunes out of gold bought land and became wealthy, colonial landowners. The most northerly railway in the world-that from Narvik on Ofoten Fiord through Gellivara to Luleawas determined by the rich magnetite deposits in Swedish Lapland. The northern part of the railway is actually within the Arctic Circle. It is safe to say that the Yukon district, in North-Western North America, would have waited long for colonisation had not rich gold-finds attracted men to that inhospitable land.

The metals rarely occur in the native or free state, the chief exceptions being gold and platinum; usually they are found combined as sulphides, oxides, carbonates, or silicates. These compounds of the metals are 
known as ores. An ore may be defined as a compound of a metal from which the latter may be extracted in quantities which pay. It is clear that a compound which would not pay to-day may pay in future if the metal is more in demand, or if improved processes of extraction are discovered. An example may illustrate this latter point. The rocks of the Jurassic escarpment of Britain, and the rocks of the same age in Lorraine and Luxembourg contain large quantities of iron compounds, but these were difficult to work on account of their large proportion of the troublesome " impurity" phosphorus until the discovery of a new process by Thomas and Gilchrist in 1879. Since then these ores have become very important sources of iron, and now support an enormous industry, especially on the Continent.

There is no general rule as to the occurrence of metals in different kinds of rocks and in association with different land-forms, but it is possible to make some important, broad statements.

Sedimentary Rocks. - The more modern sedimentary deposits contain few metals or metallic ores; the chief exceptions are gold which has been washed into alluvial deposits as the result of the disintegration and denudation of igneous and metamorphic rocks. Owing to the high specific gravity of the metal it has become more concentrated in these river deposits as the lighter rock particles have been continually washed away. Such deposits are known as "placers," and placer-gold is often the first source of gold in a new region. After the exhaustion of the alluvial deposits the gold is traced to its source in the "country rock," from which it is obtained first by crushing, and by extraction from the crushed rock by means of mercury or sodium and potassium cyanides. Placer-mining 
for gold still obtains on the western side of the American continent from California to Alaska. Much of the gold of antiquity was obtained from the river-gravels of Asia Minor and Egypt, though gold was also obtained by mining in solid rocks. It was from the sands of its rivers that the gold of the famous Gold Coast of West Africa was long obtained. Now there are gold mines "up country" in the British possessions in that region.

Platinum is obtained similarly from the sands of the rivers in the Ural Mountains; other heavy metals, such as iridium and osmium, are associated with it in the native condition.

Tin-Stone-that is, crude oxide of tin $\left(\mathrm{SnO}_{2}\right)$-is often obtained in the form known as stream-tin, because so much has been found in the river-gravels of Cornwall. It is obtained similarly from the rivergravels of the Straits Settlements, and stream-tin has recently been found in promising quantities in the rivers of Northern Nigeria.

Ores from the Sedimentary Rocks. - The Mesozoic and Palæozoic rocks, especially the limestones, contain more metallic ores than the Tertiary rocks. Iron ores were formerly mined in the English Weald from the Lower Cretaceous Wealden Beds. These ores formed one of the chief sources of British iron up to quite modern times, when the furnaces ceased to be remunerative in face of the competition of the furnaces situated on or near the coal-fields. The last furnaces went out of action about 1857 , and London still contains many examples of jron from that district. It is said that the iron railings of St. Paul's Churchyard are almost the last sample of the iron smelted in the Weald. There will probably be a reopening of the mines in the near future, but the ore will probably be taken to the coal-fields. If coal is obtained in large quantities 
from the Kent borings the whole position may be modified, and south-eastern England may again become an iron-smelting region.

Iron ores are found in immense quantities in the Jurassic rocks of Britain, where they are interbedded among the other strata. There are four chief localities - Cleveland, North Lincolnshire, Northamptonshire, and Westbury in Wiltshire. The ores of Cleveland are said to be due to alteration in strata subsequent to deposition, the lime of the calcareous deposits having been replaced by iron. As was mentioned previously, similar ores are found in the Jurassic rocks of Lorraine and Luxembourg, where a great mining industry has recently sprung up.

Iron ores are found in the Carboniferous Limestone of the Lake District rim, especially near Cleator Moor on the north-west side, and near Ulverston, Dalton, and Millom on the south-west side. Similar ores are found in the Carboniferous Limestone of the Forest of Dean and of North Wales, but not in such large quantities as in Furness and West Cumberland.

Iron ores are also found in the shales of the Coal Measures, especially in Central Scotland, in Durham, in the Yorkshire and Derbyshire Coal-field, in South Staffordshire, in the Severn Coal-fields, and in South Wales. The quantity of iron ore in the South Staffordshire district has been said to be greater than that found in any similar area in the same thickness of strata. Iron ores are obtained from the Devonian rocks of the south-western region of Britain, in the Brendon Hills, and at Brixham.

Iron ores are found in the Palæozoic rocks of the United States. The Clinton Limestone of the Appalachians furnishes much ore, from Alabama to Central New York. This limestone is of Silurian age, and is 
comparable to the Wenlock Limestone of Britain. In Pennsylvania iron carbonate or black-band ironstone occurs in the Carboniferous system, just as it occurs in the British Coal Measures. The famous ores of the North of Spain, exported in such large quantities from Bilbao and Santander, come from the Carboniferous Limestone.

Ores of lead and zinc are also largely obtained from limestone, where they often occur in irregular masses in the joints and cavities, which are so common in limestone. The lead and zinc ores of the Carboniferous Limestone of the North Pennines may be quoted as examples. Lead ores have also been obtained in considerable quantities in the Derbyshire Carboniferous Limestone, and in the Northern Pennines. The same metals are found in limestone in the Rocky Mountains. The zinc deposits of Upper Silesia, which are also in sedimentary rocks, are probably the largest sources of that metal in the world. The metalliferous deposits of the upper Oder region have been the cause of much difficulty in settling international boundaries.

Igneous Rocks are not, as a rule, rich in paying ores. Compounds of practically all the metals may be found in these rocks, but they are often present in small quantities or in combinations from which the metal would not be easily and profitably extracted. Occasionally in basic igneous rock either on the margin or the centre of a plutonic or intrusive mass there is so large a proportion of magnetite that the rock becomes a paying ore. Some of the well-known Scandinavian ores are thus found in igneous masses. For example, one of the rich deposits at Taberg near Jönköping in south-eastern Sweden is the middle of a large mass of altered basic igneous rock.

Gold is disseminated through some granites, syenites, and diorites ; the erosion of these igneous rocks leads to 
the accumulation of the precious metal in the alluvial deposits formed from the wear and tear of those plutonic rocks, as already described.

Notwithstanding these examples, workable metallic ores are only found, as a rule, in igneous rocks as a result of alteration, or in veins which have penetrated these rocks. Such vein deposits are little different in relationship from those found penetrating sedimentary and metamorphic rocks.

Metamorphic Rocks vary very considerably in their yield of metals. In such a region as the Highlands of Scotland metallic ores are by no means very plentiful, but in the similar rocks of Scandinavia some rich deposits of ore are found. The metamorphic region round Lakes Superior and Michigan contains some of the richest iron ore known; an immense mining industry is now located there, much of the ore being sent to the Ohio-Pennsylvania district. Metamorphic rocks in the Urals are also rich in iron ore. As examples of rich metallic deposits in metamorphic rocks we may quote the famous "Iron-mountain" of Gellivara in LuleaLappmark in north Sweden, which is 500 feet high, and is 3 miles long by $x_{2} \frac{1}{2}$ wide. The ore is magnetite with chromite. The rich ores of Dannemora also occur in schists, as do some of the ores of southern Sweden.

Metamorphic rocks are also rich in vein ores in some regions ; the eastern Appalachians and the Ozark Hills being examples from North America. Gold is disseminated through some of these rocks, especially the quartzites. Famous examples are the rich quartzites of Ballarat, Victoria, possibly the richest gold area for its size in the world, and the quartz rocks of the Transvaal.

It will thus be seen that there is considerable variation in the yield of ores in the three great classes of rocks, and it is similarly impossible to say of the rocks of any 
geological systems or of any land forms, that they will or will not yield metallic ores in paying quantity. Some fold-mountains of comparatively modern age are rich in metals, as in the case of the Andes; on the other hand, the Alps are singularly lacking in useful ores. The Caucasus, belonging to the same system of foldmountains as the Alps, are, however, rich in metals. The old worn-down Armorican and Variscan fragments are rich in various metals, but again there is considerable variation in the yield of different districts. Fractured crust-blocks, especially on their exposed and dissected margins, are usually rich, as may be seen in the crust-blocks of Europe and North America. The rims of the Meseta have often been quoted; mercury at Almaden, lead in the east, copper in the south, tin in the north-west, iron in the north, are among the ores found. Where a crust-block abuts against a foldmountain system metals seem to be particularly abundant, as is suggested in Spain, the Hungarian Ore Mountains, Nevada, U.S.A., Mexico, and elsewhere.

After this consideration of the circumstances of the occurrence of metallic ores, it may be advisable to give some attention to the yield of different regions as expressed in the commoner geographical terms. A few of the more important metals are taken and illustrated from the published statistics for I9II, I9I2, and I9I3.

Gold.-Approximate value of the output of Gold in I9I3 :

(I) South Africa, $£ 4 \mathrm{I}, 000,000$, or 43 per cent. of the world's total.

(2) United States, $£ \mathbf{I 9}, 000,000$, or 20 per cent. of the world's total.

(3) Australasia, $f^{I I}, 000,000$, or $\operatorname{II} \frac{1}{2}$ per cent. of the world's total. 
(4) Mexico, $£ 6,000,000$.

(5) Russia, $£ 5,000,000$.

(6) Canada, $\underset{\sim}{f} 3,000,000$.

(7) India, $£ 2,000,000$.

From this it is seen that South Africa (chiefly the Transvaal), the United States, and Australasia were responsible for three-fourths of the world's output. The relative proportions fluctuate somewhat. That of Australasia has shown some tendency to decrease during recent years, as also has that of Canada.

Silver.-The chief regions are the plateaux of Mexico and the United States (the latter including Nevada, Colorado, Montana; etc.), Canada, Australasia, and Germany. The value of the output in IgII was, in round figures, as follows :

The world's total value $£ 32,000,000$.

\begin{tabular}{|c|c|c|}
\hline exico & & 12 \\
\hline States & & $8,000,000$, or 25 \\
\hline Can & & $4,500,000$, or $I$ \\
\hline sia & & $2,300,000$, or \\
\hline erma & & $2,000,000$, or \\
\hline
\end{tabular}

Copper.-The great plateau of Western North America (with the adjacent mountains) again leads, more than four-sevenths of the world's production coming from that region; other important sources are Spain, Japan, and Australasia. The approximate values of the output in IgII were as follows:

United States $\quad £ 27,000,000$, or 57 per cent.

Mexico . . . 3,500,000

Spain and Portugal $3,000,000$

Japan • • • 2,800,000

Australasia . . 2,400,000

The commanding position of the United States is obvious.

Tin.-The ores of this metal are very local in their distribution, a very few localities producing most of it. 
The Malay States and Straits Settlements, the Dutch East Indies (Banka and Biliton especially), Bolivia, New South Wales and Tasmania, Nigeria, and the Cornish peninsula produce almost the whole. The yield in rgr2 was approximately as follows:

The world's total : . $\quad £^{16} 6,000,000$ Malay States and Straits Settlements . . . 9,000,000 Bolivia . . . . 3,000,000 Dutch East Indies . . 2,000,000 British Isles . . . I,000,000

The quantity from the different sources fluctuates very considerably; thus within the last six years for which returns are available, the mines of Banka and Biliton have yielded quantities ranging from $\mathrm{II}, 000$ tons to $2 \mathrm{I}, 000$ tons.

Lead.-The chief countries producing lead are the United States, Spain, Germany, and Mexico in the order named. The total output of the world for IgII was estimated at nearly $I, 000,000$ tons. The countries named contributed as follows :

\begin{tabular}{|c|c|c|}
\hline United States & . & $\therefore 350,000$ tons. \\
\hline Spain & . & . 170,000 \\
\hline Germany & . & - $\mathrm{I60,000}$ \\
\hline Mexico & . & . 120,000 \\
\hline
\end{tabular}

The British Isles produced about 20,000 tons in I9I2, valued at $£ 350$,00o in round figures.

Australia, in I9r3, produced lead to the value of $£$ I,800,000.

It is interesting to know that many lead ores contain a considerable proportion of silver; such ores are known as silver-lead ores. The lead ores of the Isle of Man, for example, contain a considerable percentage of the more precious metal.

Zinc.-The United States, Germany, and Belgium are 
the chief countries, producing quite three-fourths of the world's total.

The world's total in I9II was nearly 900,000 tons.

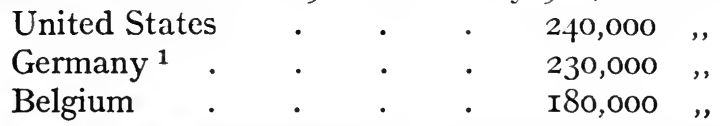

It has already been remarked that Upper Silesia is one of the richest, perhaps the richest, limited region for zinc in the world.

Iron Ore.-The three leading countries in the output of iron ore are the United States of America, Germany (including Luxembourg), and the British Isles, in the order named.

In I9II the production was as follows :

Total for the world . . I34,000,000 tons.

United States . . 4I,000,000 ,"

Germany $^{1}$ (with Luxembourg) 29,000,000 ",

British Isles . . . I6,000,000 ",

Pig Iron.-The proportion of pig iron-that is, the product of the first smelting of the ore-is not quite the same for these countries. Two of the above countries now find their supplies of ore much short of the demand, and large quantities are imported. Still, the order for the three countries is the same; the United States produce $24,000,000$ tons out of a total for the world of $65,000,000$ tons ; that is, 37 per cent. ; Germany ${ }^{1}$ and Luxembourg, I5,000,000 tons, or 23 per cent.; and the British Isles, I0,000,000 tons, or a little over I5 per cent. of the whole.

\section{Rocks AND Water Supply}

A most important part of the rock contents is water, which is contained in greater or lesser quantity in all

1 Germany has lost much of her sources of zinc and iron as the result of the Great War of 1914-I9. 
rocks. Some rocks are obviously more permeable than others; sands and sand-stones allow water to pass through between the grains of which they are composed, and in the case of the sand-stones along the bedding planes and through the joints, which are always present. Limestones are not so permeable through the mass of the rock, but they are usually well-jointed and water passes readily along these joints, widening them in course of time because of the solubility of limestone in natural waters. Clays, shales, and slates are much less permeable, in many cases so completely impermeable that little or no water can pass through the rock across the direction of stratification, but only along the bedding planes and through occasional joints. Igneous and metamorphic rocks vary very considerably, but as a rule they do not allow much water to pass except through joints and other fissures.

The water which falls as rain or snow upon the land may be evaporated, or it may run off, or some may penetrate into the rocks below. This underground water may travel for some distance below the surface, and may be there for a long time before it reaches the surface again. It is the porous rocks such as sandstones that offer the least resistance to the gradual passage of this underground water. The water stored or flowing in rocks is of vast importance, because it often supplies country houses, sanatoria, villages, and even occasionally considerable towns. The water may be reached by boring, or it may come out in the form of springs. The latter case may be illustrated first. On an exposed surface of rock, water is often seen to be dripping out gradually and in small quantities, but frequently there is a considerable outflow, and we call that a spring.

Springs may result wherever the water falls upon the surface of porous strata which have an impermeable 
bed below. The descent of the water there is arrested, and it then flows in a lateral direction. If the junction of the impervious clay or shale and the porous sand-

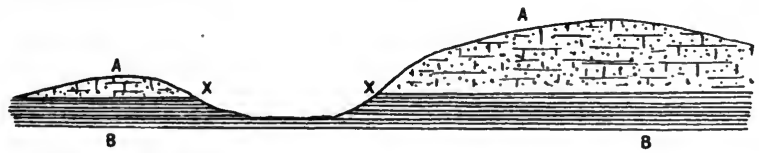

Fig. 20.-A Frequent Case of the Origin of Springs. Sandstone, A-A, which is freely permeable, overlies shale, B-B, which is comparatiwely impervious to water. Springs result at $\mathrm{X}-\mathrm{X}$.

stone occurs on a hillside, a line of springs may clearly mark out that junction.

A line of springs often marks the position and direction of a fault. Water descends through porous beds

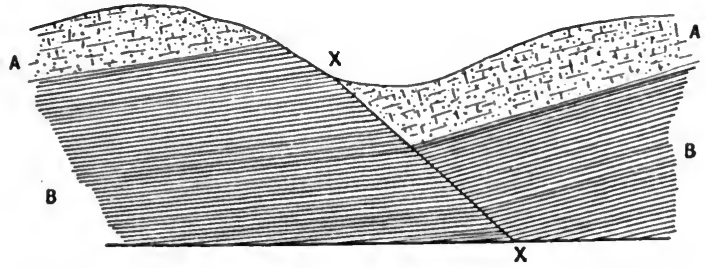

Fig. 21.-A Spring which is due to a Faulit.

At the fault $\mathrm{X}-\mathrm{X}$ permeable sandstone, $\mathrm{A}$, has been brought against impervious shale, $B$. Rain which falls on $A$ will penetrate the sandstone, and will flow out in springs at $X$.

until it reaches a clay or shale ; then it flows laterally until it comes to the fault, when it ascends under the pressure of the head of water in the rocks, and flows out at the surface in a spring or series of springs.

If the spring occurs in a region wherein there has been much faulting, or much folding, and especially if it is a region where igneous action has recently died out 
and where, consequently, heated rocks may lie at no great depth, then one or two interesting modifications of springs are possible-hot springs and mineral springs. The water of hot springs often rises along fault planes, which thus give opportunity of communication with heated regions at some distance from the surface. Mineral springs contain dissolved salts of various kinds, many of which are of considerable medicinal value. In the neighbourhood of these mineral springs sanatoria are built and baths are fitted up, or "pump rooms," where the water may be drunk. The water of some very famous medicinal springs is bottled and exported in large quantities. Many hot springs are also mineral springs.

Artesian Wells.-Another typical case of water being obtained in large quantities from the rocks is that from Artesian wells, so called because they were first of all developed in the district of Artois in France, where the rocks occur in a typical basin. The best known Artesian wells occur where the strata form a syncline, and where permeable water-bearing beds lie between impermeable strata. The London basin may again be mentioned as an example. The porous chalk dips from the North Downs under London to reappear in the Chilterns; under the Chalk is the Gault clay; over much of the Chalk area lies the London Clay. Many a London boring has been put down through the London Clay to reach the water-bearing Chalk, and so obtain some of the water which has fallen as rain on the Chilterns or North Downs. See Fig. 4, Chapter II., p. 27.

It is not necessary that the rocks form a syncline; a monoclinal fold may also furnish a good water supply if the other conditions obtain, that is, if a permeable formation occurs between impermeable beds.

Borings of this kind are now very common and are found all over the world. In the various basing of 
Europe there are now hundreds. In the United States they are very common, the chief regions being the Gulf Plains and the Atlantic Coastal Plains, the Upper Mississippi Valley and the Plains of Dakota and Kansas. In some desert or semi-desert regions such wells supply water not only for drinking but for irrigation also ; in the great basins of the Western States, in the Sahara, in Mesopotamia, and in the "Dead Heart" of Australia, for example.

At Bimerah in Queensland is an Artesian boring 5045 feet deep. There are now over 1700 such borings in that colony, and they have effected a wonderful change in the drier interior of this and the other Australian States.

Artesian wells furnish water for works of various kinds, for small towns and villages, for country houses, and, as already mentioned, for irrigation. Various salts are always present in some quantities, and sometimes, as in the Colne Valley works in the London Basin, the water has to be softened for domestic purposes. But such water is almost always wholesome and far preferable to that from shallow wells.

\section{BIBLIOGRAPHY}

(1) Geology of Coal and Coal Mining. W. Gibson. E. Arnold.

(2) Geology of Building Stones. A. How E. E. Arnold.

(3) Geology of Ore Deposits. Thomas and Macalister. E. Arnold.

(4) A Treatise on Rocks, Rock-weathering, and Soils. G. P. Merrill. Macmillan \& Co.

(5) Economic Geology of the United States. H. ReEs. Macmillan \& Co.

(6) Geology of Water Supply. H. B. Woodward. E. Arnold.

(7) Handbook of Commercial Geography, G. G. CHIsholm. Longmans \& $\mathrm{Ca}$, 


\title{
SEGT I ON B
}

\section{THE PRINCIPLES OF CIIMATIC GEOGRAPHY}

\author{
CHAPTER XI
}

THE ATMOSPHERE. WINDS, RAINFALL, AND TEMPERATURE

WE must now pass from the lithosphere to the atmosphere, with incidental references to the hydrosphere. As we have seen over and over again, climate influences the development of land-forms, it also determines the conditions of animal and plant life, and is supremely important in connection with the economic development of different regions of the world.

Climate is the average or prevalent weather condition of a place or a region, or, in other words, its average atmosphere condition. There may be included in its study the following elements : amount of sunshine, temperature, atmospheric pressure, direction and force of winds, moisture in the air and rainfall. All these are inter-related, and it is quite impossible to isolate the study of any one from that of the rest.

\section{The Atmosphere}

It is necessary to summarise our knowledge of the atmosphere. This surrounds the earth to a depth of 
possibly 200 miles, though the greater proportion of its mass is confined within a very few miles of the surface of the lithosphere. About nine-tenths of the mass of the atmosphere is contained in the lowest I2 miles.

The atmosphere may be regarded as a mixture of nitrogen and oxygen in the proportion of four volumes of the former to one volume of the latter. There are present small proportions of carbon dioxide, argon, and hydrogen, but the argon may for our purpose be grouped with the nitrogen, with which it was confused until the last twenty years. Carbon dioxide is of more importance, though it concerns the biologist more than the geographer. There is also present water-gas or vapour in very variable quantities, and this is of supreme importance to the geographer.

All these constituents are intimately mixed together, and the mixture obeys the ordinary gas laws. For example, the volume of a given mass varies directly as the absolute temperature and inversely as the pressure.

To accumulate accurate data for the determination of the climate of a place the elements mentioned above must be measured at sufficiently frequent intervals. Hence the thermometer, barometer, rain-gauge, and other instruments are the working tools of the meteorologist or student of climate and weather. A description of the apparatus belongs to the science of physics ; the geographer is concerned with the results.

The Pressure of the Atmosphere.-At the sea-level the average pressure of the atmosphere is equal to that of a column of mercury $760 \mathrm{~mm}$. or $29^{\circ} 9$ inches high. At different places on the earth's surface, and at the same place at different times this pressure is found to vary between about 28 and $3 \mathrm{I}$ inches.

The pressure will clearly diminish from the surface 
of the lithosphere upwards, because at any great altitude it is due to the weight of the air vertically above the surface under consideration. Near the earth's surface diminution of pressure is at the rate of about one inch of mercury for every rooo feet, but at higher elevations the pressure does not diminish so rapidly.

It has been stated that nine-tenths of the mass of the atmosphere lies in the lowest twelve miles, but it is perhaps of more importance to the geographer to emphasise the fact that most of the water vapour present is found in the lowest 6000 feet.

Water vapour, or water in the gaseous condition, is much lighter than dry air, the relative densities being approximately $9: \mathrm{I}_{4} 4$, hence the greater the quantity of water vapour present at any time or place the lower is the density of the air, and the less is the pressure shown by the barometer. From this follows the familiar generalisation that the lower the pressure the greater is the proportion of aqueous vapour in the air.

There is one other physical property of the atmosphere as a mixture of gases that the geographer has continually to bear in mind. It is highly compressible and as readily expands. When air is compressed heat is generated and the air is warmed, unless heat is at the same time removed in some other way. Conversely, when air expands there must be cooling, unless heat is supplied from some other source at the time the expansion is taking place. Thus warming owing to compression, and cooling due to expansion play a most important part in weather phenomena.

Yet another important physical property of the atmosphere is its relation to light and heat rays. Air is obviously transparent to light rays, and it has been established by experiment that dry air is almost perfectly transparent to rays of all wave-lengths; it is 
highly diathermous $\mathbf{1}$ as well as transparent. Water vapour is, however, not diathermous, but absorbs heat rays very rapidly. This fact is of great importance in the study of climate.

We may now proceed to study the incidence of solar energy on the earth's surface. The sun is so far distant from the earth compared with the size of the latter

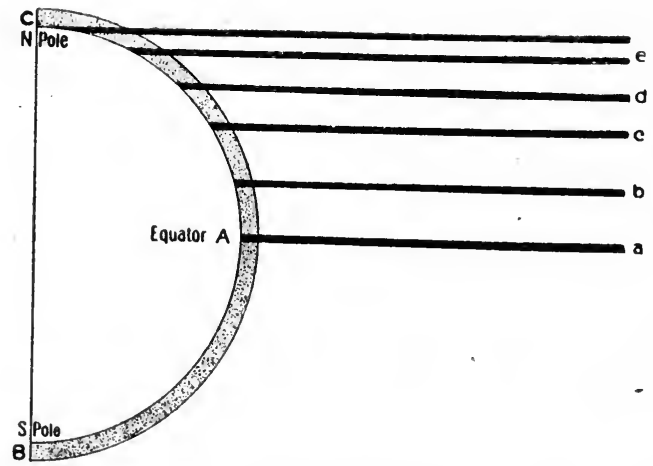

Fig, 22. -Diagram to show tile Effect of Latitude on The INCIDENCE OF TIIE SUN's RaYs, AND THE INCREASING DISTANCE OF ATMOSPHERE THROUGH WHICH THE RAYS HAVE TO pass in Higher LATitudes. The Thickness OF the ATmosphere (DOTTED BAND) IS EXAggerated.

that we may regard the solar rays as reaching the earth in parallel lines.

Let the semicircle B A C represent an arc of the earth's surface stretching from pole to pole, A being a point on the equator. Let solar rays be represented diagrammatically by the parallel lines $a, b, c, d, e$. Let the shaded part represent the atmosphere, the thickness of which is greatly exaggerated. Compare rays represented by $a$ and $d ; a$ falls vertically on the earth's

${ }^{1}$ Greek: dia, through, thermos, heat. 
surface, $d$ falling on the earth in latitude $60^{\circ}$ strikes it at an angle of $30^{\circ}$. The theoretical sun-force of the ray $d$ is one-half of that of $a$, the sun-force being proportional to the cosine of the latitude, or to the sine of the angle of incidence. Of course it must be remembered that the sun is overhead at the equator at the equinoxes only on 2Ist March and 23rd September, and it is only at these times that the theoretical sun-force is proportional to the cosine of the latitude.

It is further obvious that rays represented by $b, c, d, e$ will pass through the atmosphere obliquely, and that the length of atmospheric path is greater the higher the latitude. The light and heat rays will meet with more dust particles, larger quantities of absorbent gases (especially, of course, water vapour), and the insolation or the intensity of the active sun-force will be further reduced. To sum up, the insolation or effective solar intensity is dependent upon the latitude because of the variation of the angle at which radiations reach the surface and the distance the rays have to travel through the atmosphere.

It is estimated that about half the solar energy is absorbed by the atmosphere, the other half reaching the land or water (including snow and ice) of the earth's surface. The land surface is comprised of rocks and the soils produced by their weathering, and these are opaque not only to light rays, but to heat rays. All the solar rays are absorbed by a very thin layer of rock and soil, and the radiant energy converted wholly into heat. The rays penetrate to some depth in water, as it is to some extent diathermous; but even here the layer which completes the absorption is comparatively shallow.

The solar energy thus absorbed by land and water is partly given out as radiant heat to be further absorbed 
by the water vapour, carbon dioxide, and various dust particles in the atmosphere, and especially by that condensed water vapour which forms fog, mist, and cloud. The lower layers of the atmosphere are also warmed by contact with the land and sea surfaces.

The temperature of the atmosphere consequently diminishes with altitude, the average rate being about $I^{\circ} \mathrm{F}$. for every 300 feet of ascent. This diminution seems to continue until a height of about six or seven miles is reached, when what has been called the stratosphere is reached, in which there seems to be no farther fall of temperature with increasing distance from the earth's surface. The study of this upper layer is yet in its infancy, and though its properties may yet be shown to exert very considerable influence upon the climatic phenomena of the more accessible regions, it lies outside the scope of this book.

We may now turn to those factors which are responsible for departure from uniformity of distribution of heat on the earth's surface. If the earth were always turned similarly towards the sun, and if its surface were of uniform character everywhere, climate would vary with latitude, and the zone of greatest heat would correspond with the geographical equator.

Owing to the inclination of the earth's axis at an angle of $23 \frac{1}{2}^{\circ}$ to the plane in which it travels round the sun, the vertical sun changes its position between limits of $23 \frac{1}{2}^{\circ}$ on each side of the equator. The sun is overhead in lat. $232^{1} \mathrm{~N}$. at the northern summer solstice on 2 Ist June. It is overhead in lat. $23 \frac{1}{2}^{\circ} \mathrm{S}$. on 2 Ist December. On 2Ist March and 23rd September it is overhead at the equator. The circles of latitude parallel to the equator and at an angular distance of $23 \frac{1}{2}^{\circ}$ are called the Tropic of Cancer in the Northern Hemisphere, and the Tropic of Capricorn in the Southern Hemisphere. 
The sun is never overhead outside these limits. These relations are indicated in the diagram.

The midday angular elevation of the sun at any place on the four important dates mentioned can readily be found if the latitude is known. Thus in lat. $5 \mathrm{I}^{\circ}$ the height of the midday sun on 21st March is $\left(90^{\circ}-5 \mathrm{I}^{\circ}\right)=39^{\circ}$;

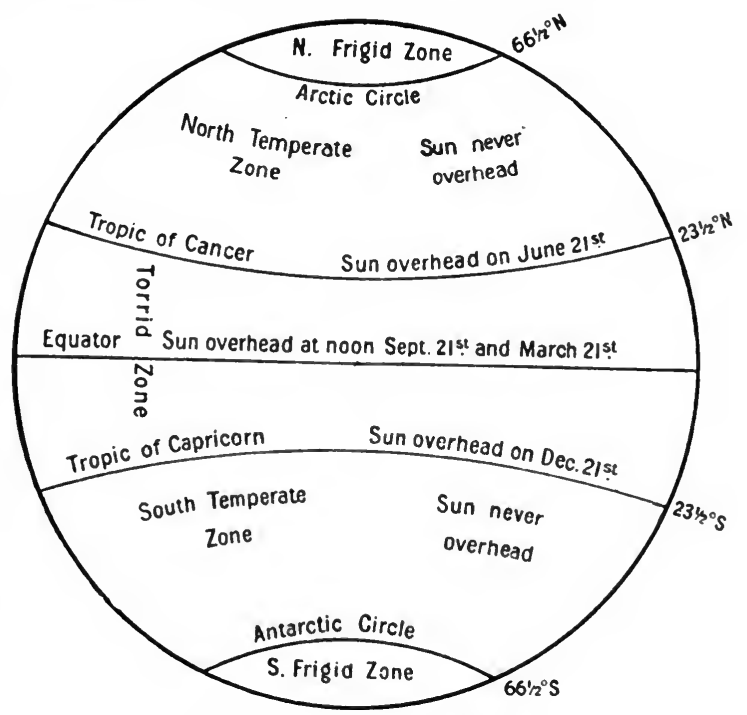

Fig. 23.-Diagram of the "Astronomical Zones" on THE Earth's Surface.

on 2Ist June it is $90^{\circ}-\left(5 \mathrm{I}^{\circ}-23 \frac{1}{2}^{\circ}\right)=62 \frac{1}{2}^{\circ}$; on 2Ist December it is $90^{\circ}-\left(5 \mathrm{I}^{\circ}+23 \frac{1}{2}^{\circ}\right)=\mathrm{I} 5 \frac{1}{2}^{\circ}$.

For New York, lat. $4 \mathrm{I}^{\circ} \mathrm{N}$., the heights are: 2Ist March and 23rd September, $49^{\circ}$; 2Ist June, $72 \frac{1}{2}^{\circ}$; 2Ist December, $25 \frac{1}{2}^{\circ}$. For Petrograd, lat. $60^{\circ}$ N., the three heights are $-30^{\circ}, 54 \frac{1}{2}^{\circ}, 6 \frac{1}{2}^{\circ}$.

It is clear that the difference in duration of daylight between the days of summer and winter is 
greater the higher the latitude: The average height of the sun is greatest in low latitudes where the variation in length of day is least. Hence in tropical regions there is little seasonal difference of temperature, but a great difference between day and night; while in higher latitudes there is relatively little difference between day and night, but greater variation between summer and winter.

The second departure from ideal planetary conditions is that dependent upon irregularities in the nature of the earth's surface. Roughly, three-quarters of the earth's surface is covered by sea, the remainder (the uncovered surface) we call land. To the geographer the distribution of land and sea is of profound importance. Such features as the occurrence of most of the land in the Northern Hemisphere, the north to south extension of North America and South America, the east to west extension north of the equator of Eurasia, the east to west extension of North Africa north of the equator, and the north to south extension of South Africa south of the equator, and the roughly rectangular outline of Australia and its situation on the Southern Tropic with east to west extension--all these and corresponding facts about the oceans must be continually borne in mind.

The above are the geographical aspects of the problem, the contrasted physical properties of water and of rocks and soils furnish the other factors. These physical differences are of fundamental importance. In the first place, water, being a liquid, allows of convection currents, and the distribution of heat by means of such currents. In the case of the solid land, conduction of heat is the chief means of transmission of heattogether with loss of heat by radiation from the land surface. It will be obvious that currents of warm and cold water will influence very considerably the actual climate 
in many regions of the world. Another point of contrast is in regard to capacity for heat. It requires much more heat energy to raise the temperature of a given mass of water than it does to raise the temperature of the same mass of rock-material by a like amount. In other words, if the same solar energy is received by land and sea, the rise of temperature of the sea is very slight compared with that of the land. During the day, or during the summer as a whole, the sea rises in temperature much more slowly than the neighbouring land. Conversely, at night the sea cools much less rapidly than the land. Hence during the hottest part of the day the sea is cooler than the land, and during the coldest part of the night the sea is warmer than the neighbouring land. The sea therefore exerts a cooling influence during the day and in summer, and a warming influence at night and in winter. This is one of the most important climatic facts in nature.

To anticipate subsequent studies somewhat, it will follow that in the same latitudes the difference between the January and July temperatures will not be nearly so great in regions near the sea as in places in the middle of the great land masses. These contrasts in temperature-ranges will be greater in higher than in lower latitudes, other things being equal, for the reasons pointed out earlier in the chapter. Some instructive examples may be given to illustrate this point. The first one is a comparison of a number of places in Europe in approximately the same latitude, and will serve as an example for cool temperate latitudes.

Cambridge. Utrecht. Berlin. Warsaw.

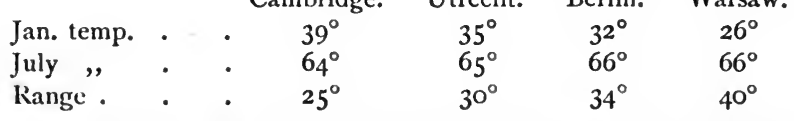

The second example compares places in somewhat 
lower latitudes in the interior of the continents with places in similar latitudes but near the ocean.

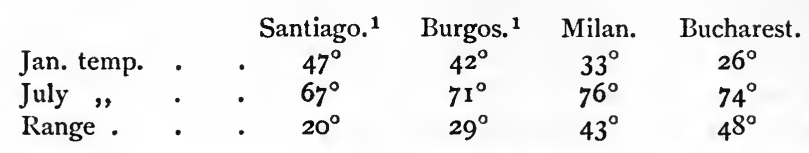

These principles will be realised more fully when we proceed to discuss concrete examples of climatic distribution, and when we can with advantage illustrate more fully general principles connected with the different effects of land and water.

\section{Latent Heat of Water}

We have also to consider another property of water which is of very great importance in respect to climatethat is, the Latent Heat of water and of water vapour. Whenever a solid substance is liquefied, or when a liquid is converted into a gas without change of composition, there must be an expenditure of heat energy. Thus to convert $\mathrm{I} \mathrm{lb}$. of ice at the freezing point $\left(0^{\circ} \mathrm{C}\right.$. or $32^{\circ} \mathrm{F}$.) into water at the same temperature needs the expenditure of 80 units of heat-that is, sufficient heat to raise the temperature of $80 \mathrm{lb}$. of water by $\mathrm{I}^{\circ}$. Again, to convert $\mathrm{I} \mathrm{lb}$. of water at the boiling point into water vapour at the same temperature requires the expenditure of 540 heat units. The heat thus expended does not produce rise of temperature, but change of state, and is known as Latent Heat. This latent heat is, of course, given out again when water vapour changes to the liquid condition or when liquid water changes to solid water (ice or snow).

This part of the subject is so important that it may be explained still further, Suppose we begin with a

+ Corrected for altitude, by adding $t^{\circ}$ for each 300 feet of altitude. 
mass of ice at, say; $20^{\circ} \mathrm{F}$.- - that is, $12^{\circ}$ below the freezing point of water. Apply heat to this. The temperature of the ice will rise until the melting point (or freezing point) is reached. Continue the application of heat. There will be no rise of temperature until the ice is melted: the heat is being "spent" in changing the physical state, and not in raising the temperature. When all the ice is melted, let the heat be still supplied. The temperature will again begin to rise and the volume of the water will be changed; at first producing contraction and then after $39^{\circ} \mathrm{F}$. expansion. From this temperature upwards there is continual expansion with increase of temperature, until the boiling point, $2 \mathrm{r} 2^{\circ} \mathrm{F}$., is reached. There is now no increase of temperature until all the liquid water has been converted into water vapour. If heat be now applied to the water vapour or gas, expansion and rise of temperature occur, just as in the case of other gases.

Water differs from other substances in that the latent heat is greater than that of any known substance. It is therefore obvious that in the vast amount of water vapour contained in the atmosphere there must be "stored" an immense amount of heat-energy. When water vapour " condenses " or becomes liquid, this latent heat-energy is set free and warms the surrounding air and the contiguous land. Clearly, then, the atmosphere of a region of great rainfall will be warmed above the temperature which would otherwise obtain. A vast amount of solar energy is thus transferred by rainbearing winds from the warmer oceans to the colder lands. We shall meet with concrete examples of the application of this and the other principles already studied, but we may here recall the common experience in cool-temperate lands that rain brings warmer weather in winter, and that during very cold weather, country 
people often say, "We shall have snow, and it will be warmer." These are every-day expressions of an important principle.

The following is a summary of these elementary but fundamental principles :

Climate depends upon-

(a) Latitude, because of the angle at which the solar rays strike the earth's surface, and because of the thickness of atmosphere to be penetrated. Theoretical sun-force at the equinoxes is proportional to the cosine of the latitude.

(b) A variation is introduced owing to the inclination of the earth, the vertical sun changing its position during a year between the limits of $23 \frac{1}{2}^{\circ} \mathrm{N}$. and $23 \frac{1}{2}^{\circ} \mathrm{S}$. The heat equator therefore oscillates between well defined limits on either side of the equator.

(c) The relation of the atmosphere to sunlight and to heat rays. Dry air is transparent and diathermous, but other constituents of the air, especially water vapour, absorb heat rays readily.

(d) The atmosphere is warmed mainly from the earth's surface by conduction and airconvection, hence temperature diminishes with altitude, the actual average rate of diminution being about $I^{\circ}$ for 300 feet.

(e) The distribution of land and sea introduce another set of factors. The great capacity of heat possessed by water causes a much less range of temperature to obtain in the sea, in the atmosphere over and near, and in the land near the sea. 
(f) The great latent heat of water, and especially of water vapour, provides a means for the transference of immense stores of heat-energy from the warmer seas to the colder land surfaces.

The application of these principles will be illustrated in the next chapter.

\section{BIBLIOGRAPHY}

See Chapter XII. 


\section{CHAPTER XII}

\section{SOME CONCRETE STUDIES IN CLIMATE}

IT may be advisable now to take certain well-marked climatic types and to study them in more detail. The region of tropical calms, where the trade winds pass gradually into the ascending air currents of the lowpressure equatorial zone, suggests itself as the first type, and from this it will be convenient to pass to other types, some of them modifications in the equatorial regions themselves, and afterwards to higher latitudes, noting some of the changes in climatic character.

The Equatorial, Hot, Rainy Belt.-This is essentially a belt of calms, and there is an absence of regular winds. The sun shines overhead, ${ }^{1}$ or at a very high altitude, all the year round; the earth's surface becomes intensely hot during the day, and the air is heated by the usual methods of conduction and convection currents. The warm air contains a great deal of moisture, and as it rises and is cooled by expansion, rain falls in great quantities. Thus the belt is hot and rainy, and some of the heaviest rainfalls of the world are recorded. There may be two very wet and two less wet seasons in the year, owing to the moving of the heat equator, but on the whole there is no really dry season; it is essentially a zone of continual rains. There is little seasonal difference of temperature, a range of very 
few degrees being all that is recorded in most parts, except in the middle of the continents and on equatorial plateaux. On the other hand, the daily range is considerable, the extremely hot day being succeeded by a relatively cool night.

As the land becomes much hotter than the neighbouring sea during the day, warm air will rise and cooler air come in from the sea; thus land and sea breezes may be a regular feature, land or offshore breezes at night, sea breezes during the day.

The typical conditions of heavy rain, low seasonal range of temperature, are well developed near the equator in the Atlantic and Pacific Oceans, in the Valley of the Amazon, the Basin of the Congo, the northern lowlands of the Guinea Coast, and the lowlands of equatorial Malaysia. The typical development ismodified on the highlands of Ecuador, the highlands of equatorial East Africa, and the mountains of Malaysia, including New Guinea. In Ecuador, which may be taken as an easily understood modification, there are well developed the three or foura scending climatic zones, tierra caliente or hot belt, tierra templada or temperate belt, tierra fria or cool belt, and tierra helida or snow belt.

The plateaux between the equatorial Andes have a warm-temperate or cool-temperate climate, according to elevation; Quito, the capital of Ecuador, at a height of 8000 feet, has almost " perpetual spring," owing to its elevation and its position on the equator. The equatorial position is responsible for the low seasonal range; the altitude, for the temperate average.

The Hot Regions of Summer Rains. - Outside the equatorial zone of rains all the year round there are on both sides of the equator narrow belts where "the rains follow the sun." The rains are therefore essentially abundant summer rains, and a well-marked dry season 
of five or six months intervenes. In these belts the difference of temperature between day and night, and especially between the hot and cold seasons, is more marked.

This climatic type occurs close to the hot wet belt, and is well developed in Nigeria, the Upper Guinea lands, the southern Congo Basin, the north coast of South America, and northern Australia. In the Congo Basin the rainy seasons of the northern and southern tributaries occur in alternate seasons; the same happens in the Amazon basin.

The Trade-Wind Type.-Beyond the zones of summer rains on each side of the equator, are the zones where the trade winds blow steadily. These winds blow from cooler to warmer regions, and the capacity of the air for moisture is being increased, hence if the trade winds blow across the land they are dry winds, absorbing moisture from the land surface. As the trade winds blow from north-east north of the equator and from south-east south of the equator, there will be a desert belt on each side of the equator, on or about the latitude of the tropics, wherever the extent of the continent allows of it. These typical hot deserts are found in North Africa, South Africa, Australia, southwestern Asia, Mexico, and southern United States, and South America. In these deserts the daily range of temperature is very great, and the seasonal range is much greater than it is nearer the equator; the hottest summers known are found in these belts. On temperature maps showing isotherms, the familiar closed areas of over $90^{\circ} \mathrm{F}$. are mostly in these desert areas; for an example, see a temperature map of Africa.

This desert condition is modified when the trade winds blow across an ocean and afterwards rise over an eastern side of a continent. Then these eastern con- 
tinental sides of the trade-wind zone may receive fairly abundant rains. The south-east of Africa, including Madagascar, the east and south-east of Australia, the south-east coast of Brazil, the Guinea coast of South America, and the West Indies and Central America receive trade-wind rains.

The Mediterranean Type of Climate. - Passing still farther from the equator we come to that type of climate which is deservedly called the Mediterranean type, because that particular region shows it normally developed. The essentials are dry, warm summers and wet, mild winters. As the sun in its northern journey reaches the limit of the tropic line, the tradewind belt, of course, swings northward and extends to between $35^{\circ}$ and $40^{\circ}$ north. The Mediterranean and northern Africa are now within trade-wind influences, and the summer is therefore dry and warm. During the winter the sun migrates southward to its southerly tropic limit of $23 \frac{1}{2}^{\circ}$ South. The trade-wind belt swings southward, and its northerly limit is now south of the Mediterranean. This region is, therefore, within the limits and under the influence of the westerly winds, the so-called anti-trades. These bring rain from the North Atlantic Ocean, and so the Mediterranean receives westerly rains. This type of climate may be summed up as follows: dry, warm summers; mild and rainy winters. It occurs in similar latitudes on the westerly side of all the other continents - middle California, middle Chile, the extreme south-west and south of Africa, south-west and south Australia.

The China Type.-On the opposite side of the great continents there is a different type; the rains come in summer and the winters are dry. The winter temperature is much lower than in the regions of Mediterranean type. Mukden in Manchuria, for 
example, in latitude $40^{\circ}$, corresponds in position with the Mediterranean. It has summer rains and dry winters; its average January temperature is $8^{\circ}$ and its average July temperature $76^{\circ}$.

Korea, in latitude $39^{\circ}$, has summer rains, with an average January temperature of about $26^{\circ}$ and a July temperature of $74^{\circ}$. Nagasaki, which is in latitude $32^{\circ}$, has a January temperature of $4 \mathrm{I}^{\circ}$ and a July temperature of $80^{\circ}$. This is the Eastern or Chinese warm-temperate type, with relatively cold winters and warm summers. The rivers of the north of China, though in the same latitude as Spain, are frozen in winter. Snow falls nearer the equator in China than anywhere else in the world, the winters are relatively so cold. Somewhat similar conditions hold in the eastern United States, except that Florida and the Gulf regions are nearer the equator than the places quoted in Eastern Asia, and the winters are not nearly so cold. Natal and the east of Australia, south of about latitude $30^{\circ}$ south, belong to the Chinese type, in both cases having milder winters, however.

The British Type of Climate, or Western CoolTemperate Type.-Passing from the warm-temperate to the cool-temperate zone, we meet with another type. Approximately $45^{\circ}$ may be taken as the arbitrary division between warm-temperate and cool-temperate, though it is notorious that there is sometimes a difference of quite $10^{\circ}$ of latitude between the two sides of a continent. Broadly speaking, the warm-temperate zone lies between $23 \frac{1}{2}^{\circ}$ and $45^{\circ}$, and the cool-temperate zone between $45^{\circ}$ and $661^{\circ}$. The trade-wind belt occupies much of the warm-temperate zone, especially in summer.

The cool-temperate type is well seen in the British Isles, most of France and Continental Europe, north 
of the Alps, and as far east as Bohemia. The part of Scandinavia south of the Arctic Circle is also of this type, excepting that the high elevation of much of it causes a modification of conditions, and gives to its plateaux an arctic climate. The winds are westerly for the most part, and rains therefore fall nearly all the year round, more especially in late summer, autumn, and winter. The range of temperature is nowhere very great. The climate may be summed up as rainy at all seasons, with cool winters and moderately warm summers.

British Columbia, with its island fringe, southern Chile, South Island, New Zealand, and Tasmania have this westerly-winds type of climate.

The Laurentian Type.-On the eastern sides of the continents in approximately the same latitude there is a somewhat different climate; the winters are a good deal colder, and the summers are very slightly warmer. Rainfall is not nearly so abundant. This has been called the Laurentian type, because its typical development is in the lands round the mouth of the St. Lawrence. Northern Manchuria and the extreme south-eastern corner of Argentina are of the Laurentian type. No part of Africa or Australasia comes within it. The rivers are ice-bound in winter and most of the harbours are closed. The following are typical examples of this Laurentian climate :

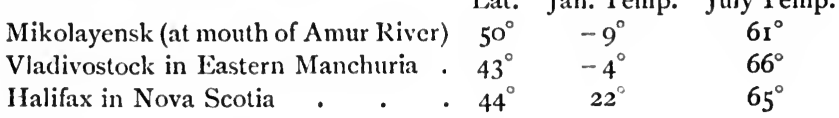

The Tundra Type of Climate.-Still farther from the equator, and within the Arctic Circle, we come to the last type to be considered,-the Tundra or Arctic Lowland type. The year here consists jof two seasons, 
a long, severe winter with very little daylight, and a short summer with continuous or almost continuous daylight, but of low intensity. The atmosphere is cold and the pressure is usually rather high. There is not much rain, and it may be called the cold-desert type. Herschel Island, at the mouth of the Mackenzie River, may be taken as a good example.

Herschel Island, lat. $69^{\circ} \mathrm{N}$. Rainfall very little. January temperature, $-20^{\circ}$; July temp., $44^{\circ}$; range, $64^{\circ}$.

The above are the chief climatic types. It will be noticed that every one is well represented in the Old World, in the Northern Hemisphere, and the development of each type is so distinct that it may be well studied there. From the equatorial basin of the Congo to the arctic tundra of Northern Russia, there is every western modification, while the Chinese and Laurentian types are represented on the eastern side of Asia.

We have thus far dealt with the normal climates of the earth's surface first of all as produced by the incidence of the sun's rays on the earth's surface, and the rotation of the earth, and as modified in the most obvious and elementary manner by the relation of the continents to the oceans on their western or eastern sides. These climatic types are the direct results of the planetary circulation, modified by relations of continents to oceans; the Mediterranean as distinct from the Chinese ; the British as contrasted with the Laurentian, for example. Now we pass to that most remarkable modification known as the "Monsoon" climate, where for half the year the normal planetary circulation is absolutely reversed, and unique conditions are set up.

The Monsoon Climate.-The typical development of this climate is in south-eastern Asia and the adjacent oceans. The great Asiatic land mass has an east to west extension, lies wholly north of the equator, and extends 
north to within the Arctic Circle. Parallel to the greatest extent of the continent lies a great ocean, the continent and ocean lying on either side of the equator. Consider first the northern summer, when the sun is north of the equator and at its farthest northward extension is vertical over the Tropic of Cancer on 2Ist June. The continent is now warmed to a temperature much higher than that of the Indian Ocean, the warmest part of the continent, having an average sea-level temperature in July of over $90^{\circ}$. North Persia and Mesopotamia, a large part of Arabia and some parts of north-west India, have then very high summer temperatures. It is obvious that there will be a low-pressure area in that region, and as a matter of fact a vast area has an average pressure below 29.5 inches. At the same time the pressure over the Indian Ocean is above $29^{\circ} 9$ for the most part. Air will therefore flow from the Indian Ocean high-pressure area to the continental low-pressure area. Owing to the influence of the earth's rotation this produces an inflow of air from south-west to northeast over southern India, from south to north over Siam, and from south-east to north-west over China. The winds blow into the continents all along the southern border of the continent from about May to October; these are the summer monsoons of southern and eastern Asia ; it is obvious they will generally be rain-bearing winds, and it is quite easy to see why south-eastern Asia has such a high summer rainfall, especially where the ground rises abruptly and alters the direction of the rain-bearing winds; as, for example, in the lands to the north of the Bay of Bengal, where the highest known rainfall in the world has been recorded. In the northern winter the sun travels south of the (quator, and is overhead at the Tropic of Capricorn on 2Ist December ; the continent now cools down quickly and the surface 
of Asia becomes much colder than the surface of the Indian Ocean. A very large area in the middle of Asia has an average January temperature of $-30^{\circ}$ or below, while at the same time the air over the Indian Ocean is at $70^{\circ}$ or over. There is thus a great difference between the continent and the ocean. Now the high-pressure area is over the continent, a large part of its atmosphere being over $30^{\circ} 5$ inches pressure, while the pressure over the Indian Ocean is below $29^{\circ} 8$ inches. The winds therefore blow from the continental high-pressure area to the oceanic low-pressure area; though again, owing to the earth's rotation, they do not blow directly from the high-pressure area to the low-pressure area. The winds blow outwards from the continent on the eastern side, and on the southern side in India and Baluchistan distinctly from the north-east. These winds blow roughly from November to March or April and are as a rule dry winds; and the period of their predominance is the "dry winter" of southern and eastern Asia. These seasonal winds are the "Monsoons."

In no other part of the world are monsoon conditions so well established, though they are felt in north-eastern Australia and in north-eastern Africa, in the southeastern parts of the United States, where planetary conditions are overridden, and wet summer winds supplant the usual trade winds to some extent.

\section{Regional Studies in Climate}

To understand the principles of climate more thoroughly it is advisable to study the climates of certain well-known regions in some detail. The following are selected as types: The British Isles, the Mediterranean, North America, India, Australasia, South Africa. The study of the climate of these regions will illustrate general principles. Some amount of repetition is 
inevitable. The student should constantly refer to the climatic maps of a good modern atlas.

The British Isles.-These islands lie in the region of prevalent westerly winds. To the casual observer the winds of the British Isles may seem very variable, but when they are tabulated year after year it is evident that on the great majority of days the wind blows from west, south-west, or north-west. There are north-east winds on a considerable number of days, but these winds are by no means so common as the westerlies.

As the commonest winds blow from over a warm ocean, they will bring to the British Isles a considerable amount of moisture. Meeting the western hilly regions as they do athwart their direction, there is heavy precipitation on the westerly side, with a general diminution towards the east, though, of course, there are many minor variations. An average annual rainfall of over 80 inches occurs in the south-west of Ireland, in South Wales, in North Wales, in the Lake District salient, and in the north-west Highlands of Scotland. Some parts of the low lands in the south-east receive less than 25 inches per annum. Very sharp "rain-shadows" are seen in the Wirral Peninsula, in the "North-eastern Plain," in the Somersetshire lowlands, all cases where lowlands lie well under the lee of moorlands on which the rainfall is relatively heavy.

The distribution of the rainfall throughout the year is approximately as follows, in percentages :

Winter. Spring. Summer. Autumn.

$\begin{array}{lllll}\text { Ireland } & 28 & 2 \text { I } & 24 & 27 \\ \text { West of England · } & 28 & \text { I9 } & 24 & 29 \\ \text { East of England . } & 23 & \text { I9 } & 28 & 30\end{array}$

The all-the-year distribution of the rainfall is obvious. Spring is the driest time on the whole.

With respect to temperature it has already been 
pointed out that the average for the year is higher than that of any region in the same latitude. The distribution of the isotherms is worth noting. In winter, as may be expected, the temperature diminishes towards the east, and the east of the British Isles is the cold region, while the oceanic side is warmer. The January isotherm of $40^{\circ}$ runs from the Orkneys, almost through Cape Wrath, along the west of Scotland, the north-west of England, along the borders of England and Wales, and across Wessex to the Isle of Wight. Some portions of eastern Great Britain have an average of less than $38^{\circ}$; and some parts of the extreme west of Ireland have an average of over $42^{\circ}$ in January. The $40^{\circ}$ isotherm may be taken as the average for the British Isles for the coldest month. In summer the isotherms run more nearly east and west, and thus the normal arrangement holds, - the north being cooler than the south. The $60^{\circ}$ isotherm for July may be taken as the average, and it extends across the middle of the British Isles from east to west, with a distinct bend southward in the Irish Sea. Only a small part of the British Isles in the south-east has a July average temperature over $64^{\circ}$, and there is only the slightest portion with an average for July below $56^{\circ}$. Thus, if $40^{\circ}$ be taken as the average of the coldest month and $60^{\circ}$ as the average of the warmest month, we may take $50^{\circ}$ as the approximate average temperature for the whole of the British Isles for the year. The student may profitably compare these constants $-40^{\circ}, 50^{\circ}, 60^{\circ}$ - with the constants for, say, the North-German plain, or the middle of Russia in similar latitudes :

\begin{tabular}{|c|c|c|c|}
\hline Coldest month (January) & $\begin{array}{c}\text { British Isles. } \\
40^{\circ}\end{array}$ & $\begin{array}{c}\text { Berlin. } \\
32^{\circ}\end{array}$ & $\begin{array}{c}\text { Moscow. } \\
12^{\circ}\end{array}$ \\
\hline Warmest month (July) & $60^{\circ}$ & $66^{\circ}$ & $66^{\circ}$ \\
\hline Comıputed average for year & $50^{\circ}$ & $48^{\circ}$ & $41^{\circ}$ \\
\hline
\end{tabular}




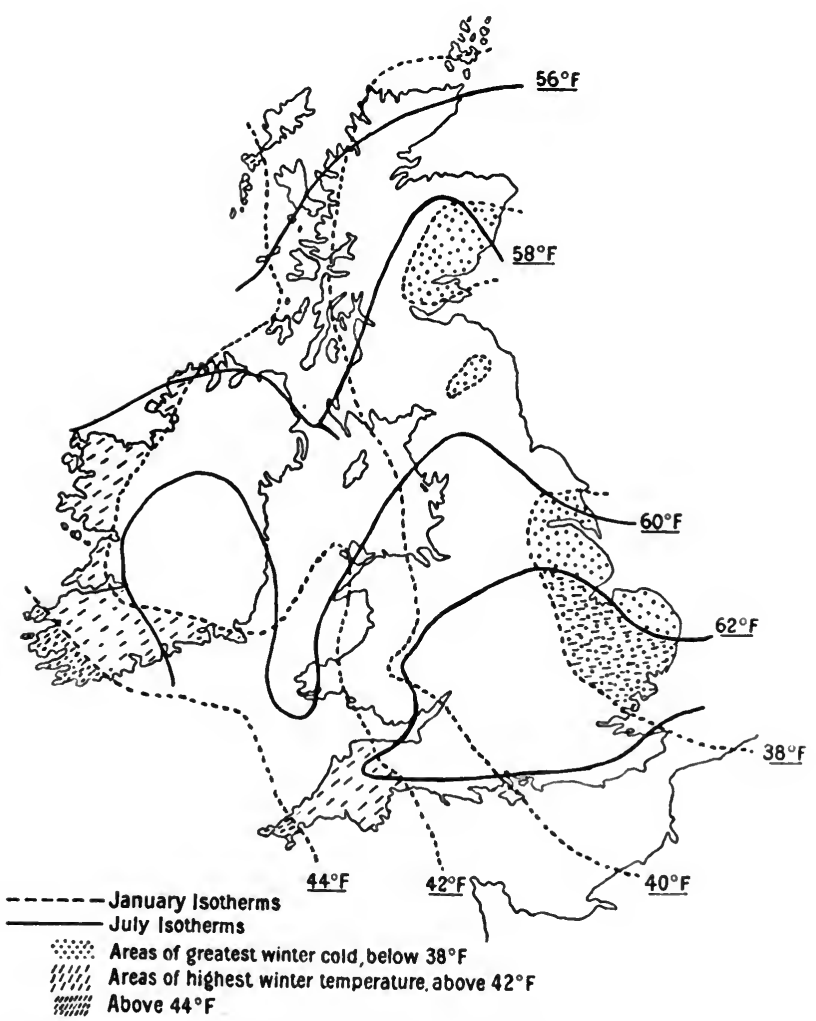

Fig, 24.-The Distribution of Temperature, at Sea-Level, IN THE BRITISH ISLES.

Note the region in the Eastern Midlands with January temperature, below $38^{\circ} \mathrm{F}$, and July temperature above $62^{\circ} \mathrm{F}$. This is the region of greatest extremes in Britain, the range being over $24^{\circ} \mathrm{F}$. There is a very small region in the north-west of Ireland where the January temperature is alove $42^{\circ} \mathrm{F}$, and the July temperature is below $58^{\circ} \mathrm{F}$, the range being below $16^{\circ} \mathrm{F}$. 
The dominant characteristics of the British climate are therefore :

(I) Predominance of westerly winds.

(2) Rain all the year round, with the least amount in late spring.

(3) The west is the wetter side.

(4) The west is warmer than the east in winter.

(5) The range of temperature is low considering the latitude, and the mean temperature is relatively high.

The Mediterranean Region.-In this region we include the Mediterranean itself, the southern peninsulas of Europe, the extreme south of France, Asia Minor and the Levant lands, and Africa north of the Great Desert. The peculiar features of Mediterranean climates have already been worked out in considering the general planetary circulation. These conditions are dry, warm summers, and mild, rainy winters, with, of course, local variations dependent upon local conditions. This type is characteristic of latitudes about $35^{\circ}-40^{\circ}$ on the west side of the continents, and it is more or less completely developed in the five continents where it is possible,-Europe, North America, South America, South Africa, South Australia.

In the Mediterranean type-region, the long, comparatively narrow, but deep inland sea, with the branch seas, the Adriatic, the Ægean, and the Black Sea, cause the peculiar Mediterranean conditions to extend far into the continents. So far east as western Persia the influence of Mediterranean conditions is clearly felt, for the limited rains there are winter rains brought by westerly winds. The distribution of rainfall at Malta may be taken as an example of well-developed Mediterranean conditions. The annual rainfall of about $2 \mathrm{I}$ inches is distributed approximately as follows : 
$=-r o$ inches winter, 3 inches spring, $I$ inch summer, and 7 inches autumn.

The most remarkable local modification in the Mediterranean region itself is the excessive rainfall of the Karst or Dalmatian coast lands on the east of the Adriatic. A maximum annual rainfall of about 200 inches is recorded in the Dalmatian village of Cherkvitce. The relatively warm winds of the Adriatic are forced to ascend rapidly the abrupt mountain wall of the Dinaric Alps, and rapid condensation and exceptionally heavy rain follows. Some rain falls in summer in this region, though not a very large proportion of the annual total. Ragusa, which has a rainfall of about 60 inches, receives only one-eighth of it in the three summer months, June, July, August. Trieste has rain all the year round; the Mediterranean type is there partly merged in the Alpine type, which is a combination of the three chief European types of Atlantic, Mediterranean, and Continental.

The following particulars of some well-known places illustrate the relation of winter and summer temperatures in the Mediterranean region:

\begin{tabular}{|c|c|c|c|c|c|}
\hline & Lat. & $\begin{array}{l}\text { Mean Annual } \\
\text { Rainfall. }\end{array}$ & Jan. Temp. & July Temp. & Range. \\
\hline Ger & - $44^{\circ} \mathrm{N}$. & 52 ins. & $45^{\circ}$ & $75^{\circ}$ & $30^{\circ}$ \\
\hline les & - $43^{\circ}$, & $22 "$ & $43^{\circ}$ & $72^{\circ}$ & $29^{\circ}$ \\
\hline $\mathrm{Na}$ & - $4 \mathrm{I}^{\circ}$, & 34, & $46^{\circ}$ & $76^{\circ}$ & $30^{\circ}$ \\
\hline Athens & - $3^{8^{\circ}}$, & 15, & $48^{\circ}$ & $80^{\circ}$ & $3^{\circ}$ \\
\hline
\end{tabular}

North America.-This continent has its greatest extension from south to north, and stretches from within the tropics to well within the Arctic Circle. It therefore exhibits all the variations of climate due to difference of latitude which may be experienced in the normal planetary circulation of winds. The great mass of western highlands introduces modifications due to 
altitude, for in that region there are differences of elevation ranging from below sea-level to nearly twenty

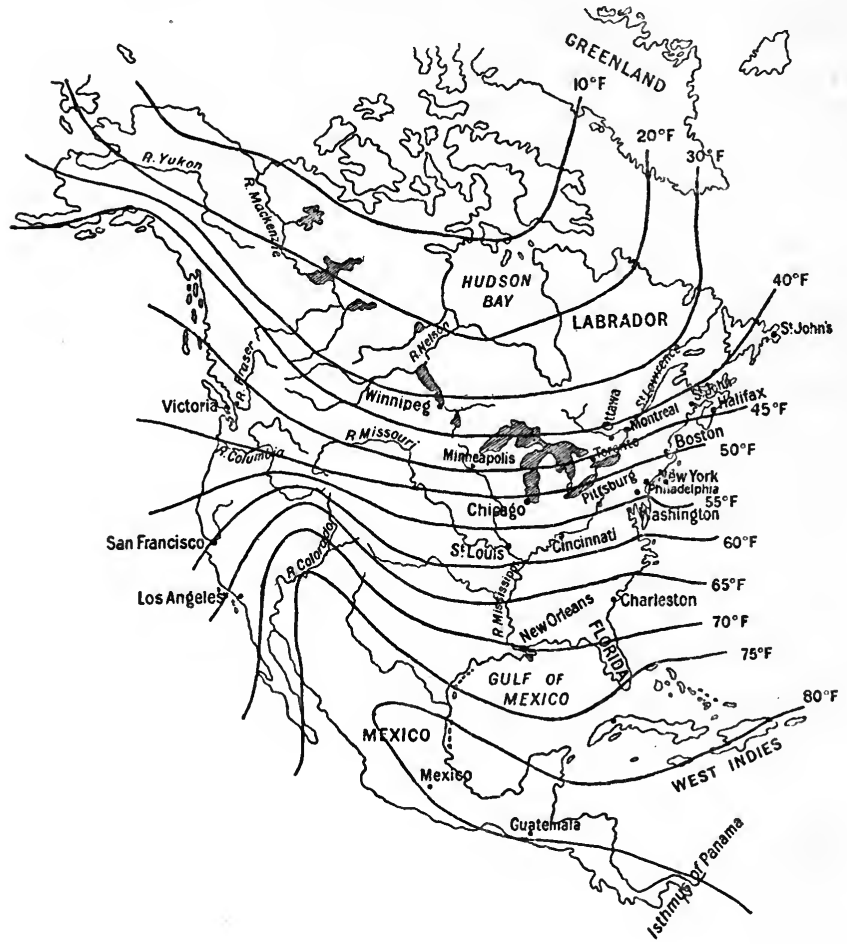

Fig. 25 - North America.

Average annual isotherms, reduced to sea-level. Note the way in which they slope from west to east on the whole.

thousand feet, which is, of course, well above the limit of perpetual snow.

North America shows characteristically the differences between the western and eastern sides of a con- 
tinent as well as those differences due to latitude and altitude. On the western side, for example, British Columbia has the British type of climate, with prevalent westerly winds, considerable rain distributed throughout the year, and a mild climate with a low range of temperature. In corresponding latitudes on the eastern side there is the Laurentian type of climate, with a much greater range of temperature, colder winters, and a lower mean annual temperature. The average annual isotherms thus slope from north-west to south-east across the northern part of North America, and there is a climatic difference of about $10^{\circ}$ of latitude ; that is, places on the eastern side have roughly the same average temperature as places in ten degrees higher latitude on the western side.

Again, on the western side, in California, the Mediterranean type of climate obtains, with dry, warm summers and mild, rainy winters. Immediately south of this zone comes the desert type of southern (Lower) California, Utah, and Arizona, corresponding to the Sahara in western Africa. In corresponding latitudes on the eastern side there is a Chinese type well developed, with wet summers and cold winters. In North America, however, the eastern climate is somewhat different from eastern Asia, for there is more rain throughout the year than in Asia. The range of temperature is not nearly so great as in south-eastern China, where, as already mentioned, lowland snows are found nearer the equator than on any other part of the earth's surface. Compare the climatic details of two places in China and eastern North America, in nearly the same latitude and otherwise similarly situated :

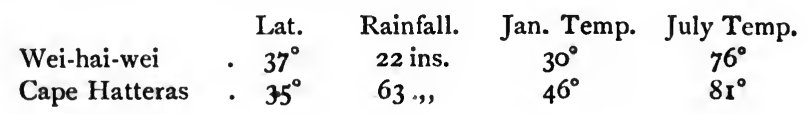


also two in similar situations but in slightly lower latitudes :

\begin{tabular}{|c|c|c|c|c|c|}
\hline & & $\begin{aligned} & \text { Lat. } \\
& \text {. } \quad 3^{1^{\circ}}\end{aligned}$ & $\begin{array}{l}\text { Rainfall. } \\
44 \text { ins. }\end{array}$ & $\begin{array}{c}\text { Jan. Temp. } \\
38^{\circ}\end{array}$ & $\begin{array}{l}\text { July Temp. } \\
80^{\circ}\end{array}$ \\
\hline & & . $32^{\circ}$ & $52 "$ & $50^{\circ}$ & $8 \mathrm{I}^{\circ}$ \\
\hline
\end{tabular}

Central America and the West Indies lie within the trade-wind belt. These winds blow from a warm ocean to a land where the highlands lie athwart their directions. It must be emphasised again that the trade winds blow from colder to warmer latitudes, and are thus essentially drying winds; but when they blow to lands where they are compelled to rise rapidly, the cooling due to rarefaction causes rapid precipitation and there is rain on the windward side of these lands. The difference between windward and leeward sides is especially well shown in some of the West Indies. The island Porto Rico, for example, has a heavy rainfall on its eastern and north-eastern side, while on the southern and south-western sides, beyond the mountains, irrigation is often necessary to secure the growth of the crops. The same holds in mountainous Central America: the eastern slopes have heavy rains, and are densely forested; the western slopes are much drier and healthier. It is notorious how the towns and chief habitable areas are found on the western side of these mountains; the eastern lands, especially the lowlands, are swampy and malarial.

A map of the annual rainfall of North America shows distinct belts running on the whole north and south. A narrow belt of high rainfall on the west coast, the rainfall rapidly diminishing inwards, with a well-defined rainshadow over the second line of mountains; a wide belt on the eastern side, with the rainfall diminishing progressively towards the west, with again a well-defined rain-shadow over the Rocky Mountains. The western 
and eastern rain-shadows meet in the plateau regions, and, as may be expected, there is a considerable desert in

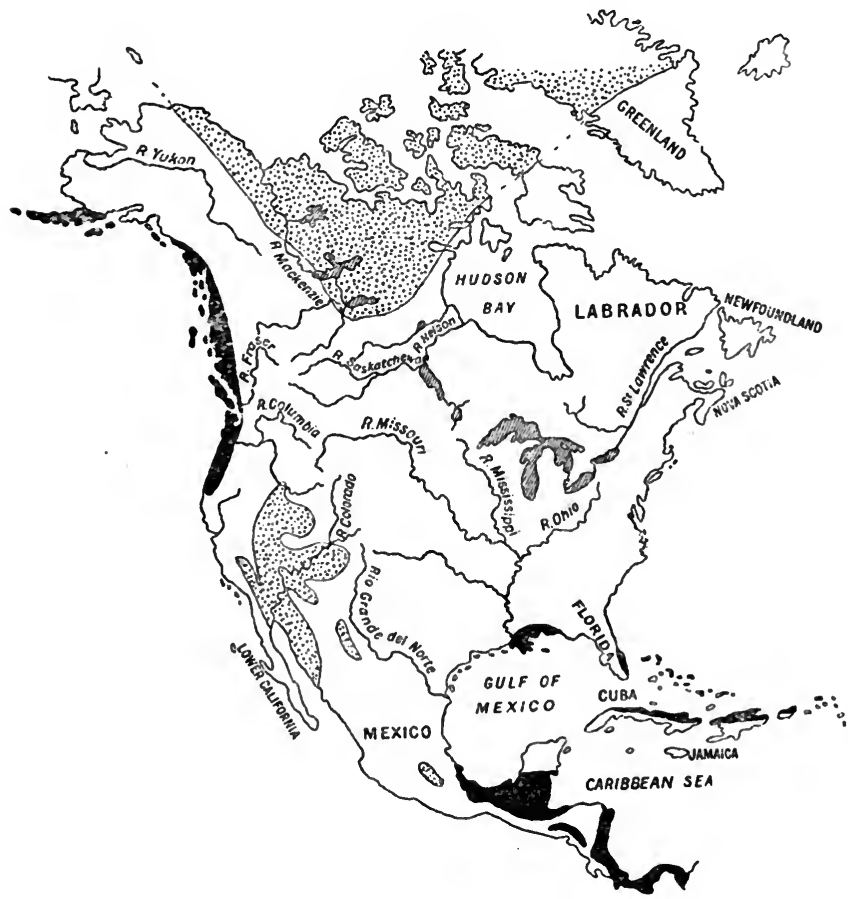

Fig, 26.--Rainfall, North America.

Regions of heavy and of light rainfall. Black, over 60 inches per annum ; stippled, below ro inches per annum (see Text). Note that the heavy rainfall occurs on the western side in high latitudes, and on the eastern side in low latitudes.

the southern part of this region, extending through parts of Nevada, Utah, Colorado, New Mexico, and Arizona.

To sum up the rainfall, there are two belts with over 
60 inches per annum, a north-western coast belt, and a region lying in the east and south-east. There are three regions with less than Io inches : a comparatively small area in Mid-Mexico, a larger area in the south-west plateau region of the United States as already mentioned, and the Tundra region of the north of the continent.

The continent also shows in a remarkably clear way the influence of position and structure on range of temperature. The usual law holds that the seasonal range increases with rise of latitude until the coldtemperate zone is reached, and the range also increases, on the whole, progressively inland. Thus we may expect the greatest difference between summer and winter in the middle of the continent and in about latitude $50^{\circ}$ to $55^{\circ}$. The seasonal range is intensified to some extent by the direction of the mountains and the consequent distribution of the rainfall, and we therefore find in the great plains of Canada approaching the Rocky Mountains a difference of some $60^{\circ}$ between the average temperatures of the coldest and the warmest months. The climatic constants of Prince Albert on the North Saskatchewan river may be taken as a type :

Lat. Rainfall. Jan. Temp. July Temp. Range. Prince Albert . $53^{\circ} \mathrm{N} . \quad 13-15$ ins. $\quad-3^{\circ} \quad 62^{\circ} \quad 65^{\circ}$

As further illustrating the range of temperature in different parts of North America, we may take three places in nearly the same latitude, on the west coast, in the middle, and on the eastern side. We observe that the seasonal range of temperature is greater on the east than on the west, while, of course, that of the middle is greater than either :

Lat. Jan. Temp. July Temp. Range.

West Coast, Fort Simpson $\quad 54^{\circ} \quad 33^{\circ} \quad 58^{\circ} \quad 25^{\circ}$

East Coast, Rigolet, on Hamil-

ton Inlet . . . .

Middle, Edmonton . $\quad 53^{\circ}$

$7^{\circ}$

$50^{\circ}$

$63^{\circ}$

$43^{\circ}$

$5^{\circ}$

$58^{\circ}$ 
The summer climate of Fort Simpson is very similar to that of the west of the British Isles; but the coldest month is some five to seven degrees colder than in Britain.

North America also furnishes abundant illustrations of the variation of climate with altitude. Referring almost exclusively to temperature, Mexico may be quoted as a good example. In that country it has long been customary to speak of three successive zones, first the tierra caliente (the hot land), the tropical lowland zone, where the climate is essentially hot and wet, especially on the eastern side. This continues up to some 3000 feet. Above it is the tierra templada (the temperate land), where the conditions are those of Northern California. This remarkably healthy zone extends from about 3000 feet to 7000 feet. Above this is the tierra fria (the cool zone), where the conditions are those of British Columbia. As Mexico extends for over Iooo miles from north to south, it is obvious that the figures given above must be understood in a general sort of way; fifteen degrees of latitude is clearly sufficient to make a great difference in the height at which these successive temperature zones succeed each other.

\section{Some Local and Secondary Features}

The climate of North America has been studied from the point of view of general planetary distribution as modified in the first degree by the shape of the continent, the direction and arrangements of its highlands, and its relation to the neighbouring oceans. There are in all continents local developments of a secondary order, the full study of which could not be undertaken in a general book like the present.

Three of the best known from North America may, however, be fittingly selected as illustrating general 
principles. These are whirlwinds, tornadoes, and Chinook winds, quite local and secondary disturbances in the general circulation of winds, but of considerable interest and notoriety because of their great importance to man.

Whirlwinds are developed in the hot, dry plateaux of the great western mountain system, and in the great plateau-plains west of the Mississippi. As the name indicates, there is a whirl of air, which is, however, of quite local character. It may have a diameter of some 50 to Ioo feet, and the spiral, whirling column may rise to 3000 feet. Such whirlwinds occur on the hot plains and plateaux in the latter part of very hot summer days. The air over the hot, parched plains becomes intensely heated, quite locally; inflowing currents are set up, and as they probably approach the region of heated air with different velocities a spiral motion is set up, and the ascending air, laden with dust particles, presents the appearance of a swaying, whirling column which moves across the parched plain with a very considerable velocity.

Tornadoes are much the same on a grander scale, and are probably the same in origin. These are most numerous in the Mississippi valley, where they often sweep across the country at the rate of 30 miles an hour. ${ }^{1}$ They are often so violent that a clean-cut path marks their track, in which trees and buildings are alike swept away. They usually occur in the afternoon or evening of warm, sultry days, when the air has been intensely heated over some lowland area. The local indraught of air upsets the equilibrium over the hot plains, and a whirlwind on a great scale is set up. These are the most destructive storms of the continent, and are justly the most dreaded.

1 This is the rate of movement of the whole tornado; the winds may blow with a velocity up to 200 miles an hour. 
Chinook Winds.-These are warm, drying winds which sweep from the snow-clad Rocky Mountains down into the high plains and valleys to the east. These winds blow in winter and in spring, and often cause rapid melting of the winter snow over a comparatively wide area. They thus make some parts of these high plains available for stock-raising much earlier than would otherwise be the case. Their origin is the same as that of the famous föhn winds of the Alps. An area of low pressure is set up on the eastern side of the Rocky Mountains owing to some local disturbance, and air is drawn from over the mountains. The air which passes over the mountain is first of all cooled by rarefaction due to lowering of pressure. Most of the moisture which is contained thus falls on the windward side of the mountains, chiefly, of course, as snow. The dry, rarefied air passes over the mountain crests and descends towards the plains. Compression, of course, occurs, and consequent rise of temperature; and the winds reach the plains or valleys as warm, drying winds, which lick up the snow almost as by magic. The Chinook winds are developed best in the valleys on the eastward side of the Rocky Mountains because of the general direction of the winds in that region. In the Alps the föhn winds occur in the valleys to the north of the main chains.

India.-India is the popular example of a region with monsoon climatic conditions. These conditions hold in Asia from Manchuria to Baluchistan, and India and Further India show the characteristic features. As in all other regions, world position and structure play their part in determining the peculiar features of the climate. The great continent to the north, the ocean to the south; the shape and position of the peninsular part of India; the position with respect to 
the equator (the Tropic of Cancer crosses continental India, and thus peninsular India is entirely within the tropics), these are the chief determining factors.

It is not necessary to repeat the account of monsoon conditions and causes; it is more to the point to state how they affect India in particular. The winter monsoon blows from north and north-east and simply strengthens the usual trade winds of these latitudes. The earlier part of this season is the "cold-weather" season of India, average temperatures of between $60^{\circ}$ and $70^{\circ}$ being recorded in the lowlands. The winter monsoon weakens in about February, and then the hot-weather season begins and lasts until the end of May or June. May is the hottest month in most parts of the north of India.

The south-west or summer wet monsoon blows from about the end of May to the end of September or early October. It is established on the break-up of the hot, dry weather, after a series of attempts, during which there is unsettled weather and many intense storms. During the summer months rain falls almost every day, and the weather is hot and steamy. In the peninsula the monsoon meets the Western Ghats - the scarp edge of the plateau-almost at right angles, and there is consequently a heavy rainfall. The middle of the Deccan is in a partial rain-shadow where the fall is slight compared with the western edge. The monsoon as it blows over the Bay of Bengal becomes thoroughly saturated with water-vapour; it thus meets the foot hills of Upper Assam, and as it ascends these the air is rarefied and cooled, and the condensation of its abundant moisture produces the heaviest rainfall known. The rainfall of Cherrapungee in the Khasia Hills reaches the enormous total of nearly 500 inches per annum, and only about I per cent. of this falls in the four months November to February. 
The mighty Himalaya system deflects the rain-bearing monsoon to some extent, and air is also drawn in by the low-pressure area to the west up the Ganges valley, and thus carries a moderate rainfall even so far as the North-West Provinces and the Punjab. The northeast monsoon is, of course, a dry wind for most of India, but Ceylon and the southern Coromandel coast receive a considerable rainfall from the wind which has gathered moisture from its journey over the Bay of Bengal. Trincomali on the east coast of Ceylon has a rainfall of over 60 inches per annum.

The peculiar case of Ceylon may be further illustrated. The south-west monsoon prevails there from early June to September ; the north-east, or continental monsoon, from October to February. The really hot weather is during the interval between these monsoons, that is, March, April, and May. To escape this hot season there have been established on the hills sanatoria which are now famous, and of great importance to European residents both in Ceylon and Southern India. Newara Elsya is at an elevation of over 6000 feet, and has an average temperature of $58^{\circ}$, with a very low range. Of course, Ceylon being almost on the equator, and being an island, cannot have a great seasonal range. -The following statistics are significant :

\begin{tabular}{|c|c|c|c|c|}
\hline & $\begin{array}{l}\text { Lat. } \\
\text {. } 7^{\circ} \mathrm{N} .\end{array}$ & $\begin{array}{l}\text { Rainfall. } \\
88 \text { ins. }\end{array}$ & $\begin{array}{c}\text { Jan. Temp. } \\
79^{\circ}\end{array}$ & $\begin{array}{l}\text { July Temp. } \\
81^{\circ}\end{array}$ \\
\hline li. & - $8^{\circ}$, & 62, & $79^{\circ}$ & $83^{\circ}$ \\
\hline
\end{tabular}

To return to the general study of India, the seasonal range increases $(a)$ with distance from the equator, $(b)$ with distance from the sea, hence there is the considerable range, for low latitudes, in the Upper Ganges Plain of about $26^{\circ}$, in the Punjab of over $30^{\circ}$. The seasonal range is also great on the plateau, and reaches 
about $25^{\circ}$. The statistics of Agra in the Ganges valley and Multan in the Punjab are sufficiently important to be given :

\begin{tabular}{|c|c|c|c|c|}
\hline & $\begin{array}{l}\text { Lat. } \\
27^{\circ}\end{array}$ & $\begin{array}{c}\text { Rainfall. } \\
28 \text { ins. }\end{array}$ & $\begin{array}{c}\text { Jan. Temp. } \\
60^{\circ}\end{array}$ & $\begin{array}{c}\text { July Temp. } \\
86^{\circ}\end{array}$ \\
\hline Multan & . $30^{\circ}$ & 7, & $57^{\circ}$ & $93^{\circ}$ \\
\hline
\end{tabular}

The Thar (i.e. Desert) in North-Western India is almost rainless. The winds in that region come for the most part from the lands west and north-west. There is a low-pressure area in the Punjab and air is drawn in to this according to the usual rule north of the equator, that is, counter clockwise. The desert is south of this low-pressure area, hence winds come from the west and north-west. The lower Indus valley is also nearly rainless, and its cultivated areas depend upon the overflow of the Indus or upon irrigation. The river is fed by the snows of the Himalaya and the winter snows of the Upper Punjab.

Karachi, west of the delta, and the great place of export for the wheat and barley of the lower Indus plain, has an average rainfall of 8 inches. Its seasonal range of temperature, $65^{\circ}-83^{\circ}$, is comparatively low because of proximity to the sea.

The southern side of the mighty Himalaya exhibits very well the consequences of the usual variation of temperature with altitude. The tropical malarial terai, densest towards the east, occurs at the foot, and tropical vegetation continues upwards to about 4000 feet. Deciduous vegetation (indicating a temperate climate) follows, gradually passing into coniferous forest, and this continues to II,000-I2,000 feet. Alpine pastures succeed, with tundra vegetation highest of all, to about I7,000 feet, and, of course, above that is the zone of ice and snow. The magnificent intermont valleys, especially such as the great vale of Kashmir, show the 
intermediate climatic conditions and the characteristic vegetation; thus in the valleys of Sikkim at 7000-8000 feet, brilliant rhododendrons are a prominent feature.

Australasia.-The essential features of the climate may again be best grasped by noting (I) that Australia lies entirely south of the equator, between latitudes $\mathrm{II}^{\circ} \mathrm{S}$. and $39^{\circ} \mathrm{S}$., and that the Tropic of Capricorn crosses it almost in the middle; (2) that the continent is of compact structure, and has its greatest extension from west to east parallel to the equator; and (3) that it has the open ocean on all sides except the north.

Without elaborating the different regions very fully, the establishment of four climatic divisions will be readily understood: (I) The tropical monsoon region of the north; (2) the region of south-east trade winds in the east and south-east; (3) the south-west and south, with Mediterranean conditions; and (4) the rainless desert in the western middle part.

The monsoon region is in the north and north-east. The rainfall mostly comes with the summer monsoon, but it is not so heavy as in some regions owing to the absence of very high mountains to effect a very large condensation. The fairly heavy rainfall does not extend very far into the interior. The seasonal range of temperature is low, increasing, of course, in the interior. The statistics of Cape York on York Peninsula and Port Darwin to the west of Arnhem Land may be used to illustrate this region. Both have very wet summers from about the end of December to the end of March, and are very dry from June to September :

Lat. Rainfall. Jan. Temp. July Temp.

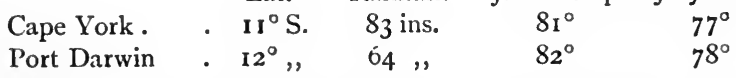

South Queensland and New South Wales are in the 
region of south-east trade winds. The mountains are wider, but not very high. There is, however, a welldefined rain-shadow, especially towards the south where the mountains are somewhat higher. The western slopes of the hills are therefore drier and the plains of the Darling-Murray system receive a rainfall diminishing in amount towards the west, until the desert with less than ro inches is reached. The temperature ranges in the interior are, of course, considerable. Sydney and Bourke (on the Darling River) may be taken as typical studies of the trade-winds region.

Lat. Rainfall. Jan. Temp. July Temp. Range.

$\begin{array}{llllll}\text { Sydney . } & 33^{\circ} & 47 \text { ins. } & 71^{\circ} & 53^{\circ} & 18^{\circ} \\ \text { Bourke . } & 3^{\circ} & 15, & 84^{\circ} & 50^{\circ} & 34^{\circ}\end{array}$

The south and south-west receive winter rains from the westerly winds, which blow when the trade winds have swung to the north. This region corresponds to the Mediterranean and to middle California. The summers are hot and dry. The most favoured parts are the southward extension of the continent in West Australia and South Australia and Victoria. The Great Australian Bight carries its coast lands too far north, where little rain falls. Perth and Adelaide, the two capital towns, may be taken as examples. Both have most of their rains in the winter months, May to August. The winters are cool and the summers decidedly hot :

Lat. Rainfall. Jan. Temp. July Temp. Range. $\begin{array}{llllll}\text { Perth } & 33^{\circ} \mathrm{S} . & 33 \text { ins. } & 76^{\circ} & 55^{\circ} & 21^{\circ} \\ \text { Adelaide } & 30^{\circ}, & 20, & 74^{\circ} & 5^{\circ} & 23^{\circ}\end{array}$

The desert occupies most of the western tableland and some parts of the central lowlands. The zones of annual rainfall curve round it somewhat eccentrically, with its own centre about on the tropic and in the 
longitude of the western third part of the continent. (The student will, of course, study a rainfall map, together with an orographical map.) The rainfall is low ; the range of temperature, both seasonal and daily, is high. The desert corresponds to the Sahara, though fewer oases seem to exist than in the great African prototype. Alice Springs on the overland telegraph route, and almost in the latitude of the tropic, and Strangeway Springs south of Lake Eyre, may be taken as typical places:

Lat. Rainfall. Jan. Temp. July Temp. Range. Alice Springs $\quad{ }^{\circ} 3^{\circ} \mathrm{S}$. ro ins. $87^{\circ} \quad 52^{\circ} \quad 35^{\circ}$ (Altitude about 2000 feet)

Strangeway Springs $27^{\circ}$,

$6, \quad 84^{\circ}$

$55^{\circ}$

$29^{\circ}$

The three large islands and island groups of Australasia may be very briefly considered. New Guinea is almost equatorial, and has very heavy tropical rains. The mountain barrier which runs east and west rises to $\mathrm{I} 3,000$ feet, and separates the island into two climatic provinces. The north has very heavy monsoon rains from December to March, that is, in the southern summer. The south receives mostly winter rains from the south-east trades, which bring rain from the southern Pacific when the sun is north of the equator. The temperature is high and the seasonal range is low. Data are still wanting for most parts, but the seasonal range at Port Moresby seems to be little more than $3^{\circ}$ or $4^{\circ}$, that is, from $81^{\circ}-82^{\circ}$ in January to $77^{\circ}-78^{\circ}$ in July.

New Zealand.-North Island is obviously Mediterranean in latitude, and it has a climate of that type somewhat modified. Winter rains are heaviest, but the surrounding ocean modifies the usual summer drought of Mediterranean regions. South Island and the 
southern part of North Island are in the region of prevalent westerly winds. These winds are more perfectly developed in the Southern Hemisphere than in the Northern owing to less interference by great land masses. The westerly side is therefore the rainy side, as in Britain and France. The western slopes of the New Zealand Alps have a very heavy rainfall, there being over Ioo inches on most of the west coast. The rainfall map shows the rain-shadow of the mountains in a way that reminds one of the rain-shadow of Scandinavia. The plains to the east have only an average of about 20 to 25 inches, and are therefore well adapted for sheep-rearing, which has become the greatest industry of South Island. North -Island has no dominant mountain range like that of South Island, and the rainfall is therefore more evenly distributed over the whole island. Owing to the insular position the whole of New Zealand has a comparatively low seasonal range :

Lat. Rainfall. Jan. Temp. July Temp. Range.

\begin{tabular}{|c|c|c|}
\hline land & S. & \\
\hline Inington & $4 \mathrm{I}^{\circ}$, & \\
\hline Christchurch . & $43^{\circ}$ & \\
\hline Hokitika & $42^{\circ}$, & 118 \\
\hline
\end{tabular}

Tasmania is also in the region of prevalent westerlies and has rain at all seasons. It is climatically the counterpart of north-western France. The west is wetter than the east owing to the position of the mountains, and the drier eastern slopes are suitable for sheep-rearing. The rainfall on the west reaches 80 inches or more ; on the east coast it descends to $20-25$ inches. Hobart may be taken as an illustration, though its rainfall is low owing to its being in the rain-shadow:

Lat. Rainfall. Jan. Temp. July Temp. Range. Hobart. $\quad 43^{\circ} \mathrm{S} . \quad 24$ ins. $62^{\circ} .46^{\circ} \quad 16^{\circ}$ 
South Africa.-We shall include here all Africa roughly south of the Zambesi, which will make it correspond broadly to Australia. The differences are important, however. Australia is an island; South Africa passes gradually into equatorial Africa. Australia has its greatest extension east to west; South Africa has its greatest extension north to south. The region as defined above merges into the tropical types -tropical lowland towards the east, tropical savana in the middle, tropical desert in the west.

Owing to comparative uniformity of structure the different provinces are determined by relation to the planetary system and influence of neighbouring oceans more than by differences in build. The three well-defined provinces are : (I) The south-east tradewind region, including Natal, the Orange Free State, the Transvaal, and Portuguese East Africa. (2) The extreme south and south-west, with a Mediterranean climate ; and (3) the desert region of the middle and west.

The south-east trade winds meet the eastern mountain scarp of the Madagascar table-land, and the lower western parts of this large island have a pronounced rain-shadow. Antananarivo has a rainfall of over 50 inches per annum, Tamatave one of 90-roo inches. Most of the rain falls in summer, as may be expected. Natal rises in terraces until the great scarp of the Drakensberg is reached. The rainfall is thus caught on the south-eastern side, and the high veld of the interior is relatively bare and dry. The eastern margin of the high veld is thus much more fertile than the western part, which merges into the deserts of the west :

Lat. Rainfall. Jan. Temp. July Temp. Range.

$\begin{array}{llllll}\text { Durban. } & 3^{\circ} \mathrm{S} . & 80 \text { ins. } & 76^{\circ} & 64^{\circ} & 12^{\circ} \\ \text { Pretoria } & 25^{\circ}, & 27 " & 71^{\circ} & 52^{\circ} & 19^{\circ} \\ \text { (4750 feet) } & & & & . & \end{array}$


The extreme south and south-west fall within the zone of summer trades and winter westerlies, hence there is a small region with rain at all seasons, from the south-east trades in the summer, and from the westerly winds in winter. This is a modified Mediterranean type, with some rain in the summer instead of dry trades as in the type region. As no part of South Africa reaches $35^{\circ} \mathrm{S}$. latitude, it is only the extreme 'south which receives the Mediterranean type of rains. It corresponds with Morocco rather than with the Iberian peninsula.

The places selected for illustration are :

Lat. Annual Jan. Temp. July Temp. Range.

$\begin{array}{lccccc}\text { Cape Agulhas } & 33^{\circ} \mathrm{S} . & 16 \text { ins. } & 67^{\circ} & 54^{\circ} & 13^{\circ} \\ \text { East London . } & 33^{\circ}, & 24, & 70^{\circ} & 57^{\circ} & 13^{\circ}\end{array}$

The desert region includes northern Cape Colony, Bechuanaland, and Damaraland, the latter two being on the borders of the Kalahari desert. Rain seldom falls except on the higher parts. The seasonal ranges of temperature are considerable, and the daily range is often very great. On the dry plateaux the cold of the nights is frequently intense. This is mainly a stock-rearing region, as there is not enough rain for agriculture, and there are few rivers from which water for irrigation can be derived. Angra Pequena on the coast and Windhoek (altitude 5400 feet) on the plateau are selected as the types:

Lat. Rainfall. Jan. Temp. July Temp. Range. Angra Pequena ${ }^{1} 26^{\circ} \mathrm{S}$. (Scarcely any) $67^{\circ} \quad 57^{\circ} \quad 10^{\circ}$ Windhoek $\quad 22^{\circ}, \quad 15$ ins. $\quad 74^{\circ} \quad 56^{\circ} \quad 18^{\circ}$ (5400 feet)

${ }^{1}$ A cold current which sets along the coast from the south reduces the temperature of Angra Pequena very considerably. 


\section{BIBLIOGRAPHY}

(I) Weather Science. R. G. K. LempFert. T. C. \& E. C. Jack.

(2) Climate and Weather. H. N. Dickson. Home University Library : Williams \& Norgate.

(3) Modern Geography. Marion Newbigin. Home University Library: Williams \& Norgate.

(4) A Text-Book of Geography. A. W. ANdrews. E. Arnold.

(5) Elementary Meteorology. W. M. DAvis. Ginn \& Co.

(6) Climate. R. DE C. WARD. Progressive Science Series : J. Murray.

(7) College Physiography. R. S. TARR AND I. MARTin. The Macmillan Company. 


\title{
SEGT I O N \\ BIOLOGICAL GEOGRAPHY
}

\author{
CHAPTER XIII
}

\section{PLANT GEOGRAPHY}

THE growth of plants is controlled by physical circumstances, chief among which are heat, light, water in the air and soil, and the nature of the soil and subsoil. Thus the climatic factors which mainly determine the character and luxuriance of vegetation are the temperature, the amount of sunlight, and the rainfall. It may be said that in tropical regions climate overrules soil and subsoil, but in temperate climates the nature of the soil is of great importance. It is easy to see, from well-known concrete examples, that the nature of the soil is a very important factor in cooler regions ; thus central Ireland has a climate that is not very different from that of the Lancashire and Cheshire plain, yet its vegetation is different. The Betuwe and Veluwe of Holland, the "Good Island " and the "Bad Island," are in the same climatic province; the fertility of the one is remarkable, the relative barrenness of the other is striking. The Landes of the south-west of France are in the same latitude and have a climate not very different from that of the valley of the Rhine; the sandy subsoil of the 
one, and the fertile mixed alluvium of the other make a great difference in the productivity. On the whole, climate, in the wide sense, must be considered the primary factor in the control of vegetation, and we shall therefore study plant associations as determined by climate.

The study of plant associations is the special science of Plant Ecology, which is obviously a compound of Botany and Geography. It is beyond the limits of this book to attempt anything like an extensive study of that branch of science; we shall confine ourselves to plants and plant associations which are important to man, and thus bring this part of the subject into line with the general scope of the work. Broadly speaking, trees may be taken as representative of plant life in general, and this point of view will be emphasised in this and the next chapter. The boundaries and limitations of forests are found to agree broadly with the boundaries of climatic provinces, and we shall therefore subdivide the study of plant life according to those different climatic provinces.

\section{HOT LANDS}

Broadly speaking, these are the lands between the tropics of Cancer and Capricorn, a belt of the earth's surface $47^{\circ}$ in width. Their limits are approximately the two desert belts which lie on either side of the Equator. The equatorial lowlands may be taken as the starting-point, and from there we may pass on the one hand to those tropical latitudes where the rainfall is seasonal or not so heavy, and on the other to those plateaux and mountains where the same changes occur owing to change of altitude. There are four fairly distinct types in these hot lands :

(I) The Equatorial Lowlands, or Amazon-Congo Type. 




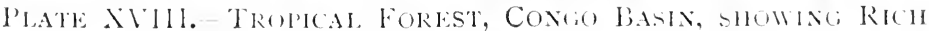
INIERGRWIII AXD PARASITIC C'RELIERS. 


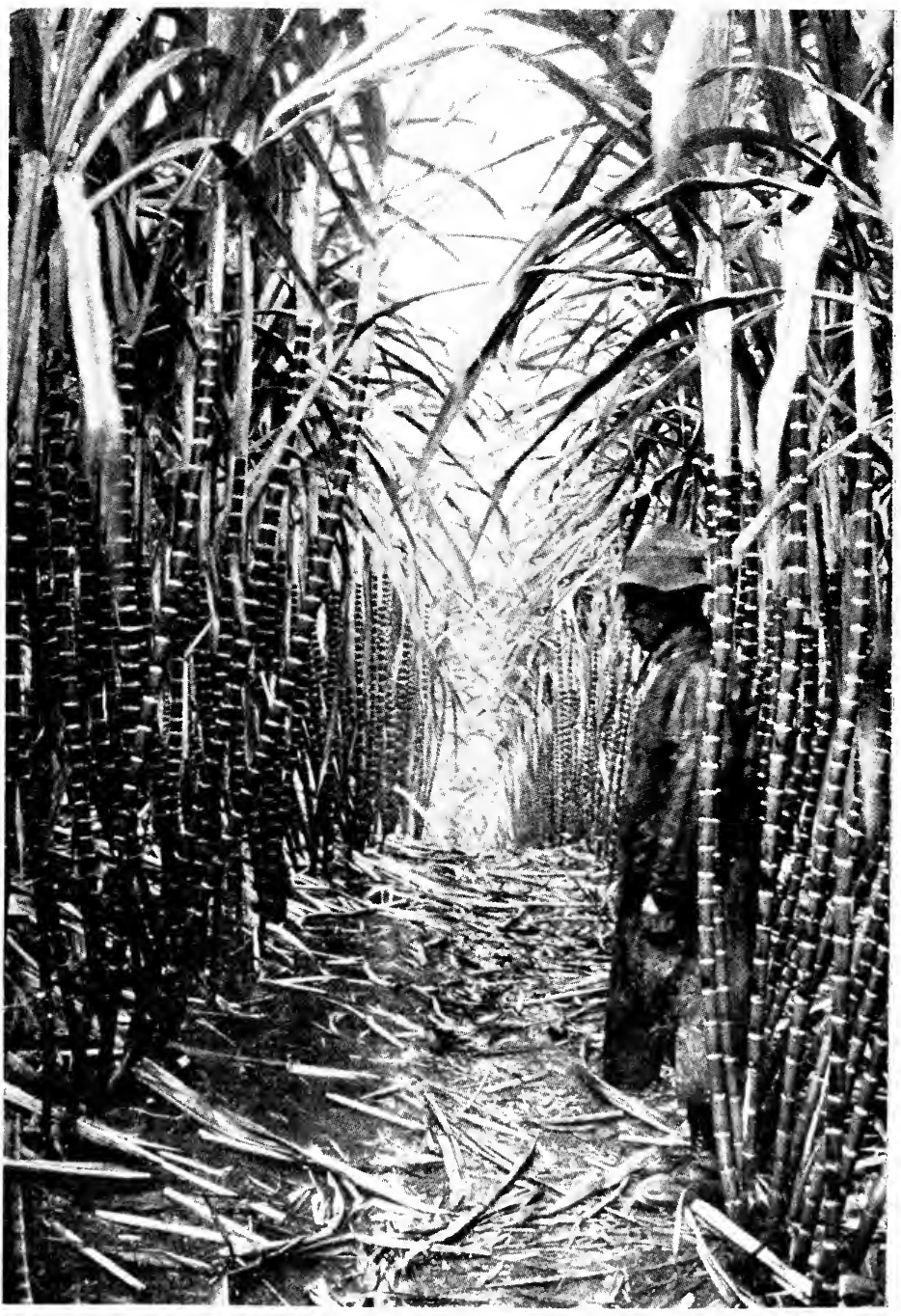

Plate XIX.-Sandwich Islands. An HaWaitan Sugar PLANTATION, 
(2) The Summer Rains or Monsoon type ; southern India Type.

(3) The Tropical Highlands, or Uganda Type.

(4) The Tropical Desert, or Sahara-Kalahari Type.

Equatorial Lowlands - Amazon-Congo Type. - The climatic characteristics are rain throughout the year and a uniform high temperature. There may be two relatively wet and two relatively dry seasons, riear the equator itself, the two wetter seasons occurring soon after the equinoxes; and as we get farther away from the equator there are wet and dry seasons, the latter increasing in length the farther we go from the equator.

The atmosphere is hot and steamy, and plant growth is rapid and exuberant. These lowlands are covered with dense primeval forests, in which an immense number of trees struggle for existence. Prof. I. C. Russell is responsible for the statement that there are probably more species of trees in roo sq. yards in a tropical lowland forest than in Ioo sq. miles in a forest of central Canada.

The forest is so dense that only a diffused greenish light, a sort of twilight, reigns in the lower glades, while the successful competitors above are bathed in the intense tropical sunlight from a sun that is never far from overhead at midday in any season. The undergrowth is very dense, and mosses, lichens, and fungi grow on the damp mould below, while creepers and parasitic plants climb up to the light above, and hang their aerial roots or lianas in the spaces below. Numerous species of vines, palms, and tree ferns mingle with an immense number of species of woody trees, whose great roots spread over the rich moist soil, while many of the trees develop root-like buttresses eight or ten feet from the ground.

The stuffy, gloomy vault, hot and moist, like the 
atmosphere of a palm-house, is generally thinly peopled. It has to be cleared before man can grow his food plants in security; and it is one continual fight between man and nature, for the forest rapidly reconquers any clearing, and constant vigilance and effort are the price he must pay to hold his own. In the more favoured localities gardens of wonderful luxuriance have been won, and the natural products of the forest are cultivated.

The temperature throughout the year is so uniform that there is no one time for leafing and flowering of the trees and other plants. They have adapted themselves to some very slight change in the atmospheric conditions, and so there are always some plants bursting into leaf and putting forth flowers or producing seeds.

The vegetable products of the tropical lowland forest are numerous and valuable. Among the most important is the widely-spread coco-nut palm, whose fibres, leaves, and fruits are all useful to man ; mahogany, ebony, and lignum-vitæ among timber trees, and logwood and brazil-wood among dye-woods. The plantain, the banana, and the yam; the sugar palm, the sago palm, and the manioc are among other useful plants common in these forests. Caoutchouc, rubber, balata, and gutta-percha, many spices and condiments such as vanilla, cloves, nutmeg, and ginger, are other important products from the equatorial forests. In addition to all these, rice may be mentioned, though its home is rather in the monsoon lands.

This forest type has its greatest development in the basin of the Amazon, the lower Guinea lands, and the basin of the Congo. Iquitos, in the Amazon valley, is $2^{\circ}$ colder in January than July, the average temperatures being $79^{\circ}$ and $77^{\circ}$, with a rainfall of over Ioo inches. Para, at the mouth of the great river, 
has the same temperature in January and July, $78^{\circ}$, and a rainfall of about 90 inches. Akassa, at the mouth of the Niger, has January $78^{\circ}$ and July $76^{\circ}$, with a rainfall of 140 inches. Libreville, on the French Congo coast, January $78^{\circ}$, July $73^{\circ}$, and rainfall about roo inches; these may be taken as types of the climates of these tropical lowlands.

Summer Rain and Monsoon Type-South India Type.Passing from the equatorial lowlands with perennial rains we come to regions where there are distinct dry and wet seasons; the rains come in summer. The climatic characteristics of importance to plant growth are: the occurrence of a well-marked period of drought, a less total rainfall, a greater seasonal range of temperature, and the occurrence of strong dry winds in the " winter " or dry season.

Forests are densest, other things being equal, where the temperature is most uniform and the atmosphere is always moist. Hence in lands with monsoon and summer rains the forests are different in type from those of the hot, wet equatorial lowlands; the trees over a wide area are more often of the same species ; the forest is much more open; there is a periodicity of growth, and many trees shed their leaves during the dry season.

The chief regions where this type holds are India, Burma and Siam, Northern Australia, Central America, and the Guiana lowlands. The teak forests of Java, the Malay Peninsula and Burma show the alternation of the dry season and the summer rains very well in the falling of the leaves. Teak is well known as one of the most useful hard timbers.

The forests in this zone are not so rich in useful products as the wet equatorial lowlands, but the ground is more easily cleared and the conditions are healthier. Hence these regions have always been more thickly 
peopled, and highly developed and prosperous agricultural races are found there. Some of the products are the same as from the hot rainy forests, such as mahogany, logwood, the oil palm, rice, sugar, and the banana. Coffee, tea, indigo, jute, maize, wheat, barley, and cotton can all be grown in these lands. Maize may be regarded as the typical cereal crop; wheat and barley are grown as winter or dry season crops, often by the aid of irrigation, as in the lower valley of the Indus.

\section{The Tropical Highland Type - The Uganda or} Ecuador Type.-From general principles it will be readily understood that the two types already discussed will be modified at a considerable altitude, and a new type will result, especially on the higher tropical plateaux. The equatorial lowland type holds up to roughly 3000 to 4000 feet ; then gradually a modified type is established. The three or four ascending zones of climate already mentioned determine corresponding vegetations. The climatic essentials are comparatively low seasonal range owing to low latitude, but a considerable general lowering of temperature owing to altitude. The general climate is that of cool temperate or warm temperate lands according to elevation. Quito has already been quoted as having "perpetual spring": it is 8000 feet above sea level. There may be, and usually is, a considerable difference between night and day, and the night is sometimes very cold. The temperatures of two places in Africa and America are given to illustrate the "perpetual spring" character of the climate :

Fort Smith, on the Uganda Railways, on the Kikuyu Plateau, Uganda.-Latitude, $I^{\circ}$ S. Height, 5200 feet. January temperature, $63^{\circ}$; July temperature, $58^{\circ}$.

Bogota, on the Columbian Plateau, S. America.- 
Latitude, $4^{\circ} \mathrm{N}$. Height, 8700 feet. January temperature, $58^{\circ}$; July temperature, $57^{\circ}$.

Maize, wheat, and barley are the cereals of these plateaux; and Mediterranean fruits, such as pineapples, oranges, apricots, are grown. The mulberry, for silk, flourishes in many parts. The grass lands, where the rainfall is sufficient, feed large herds of cattle, llamas, and sheep.

These typical plateaux may be too dry in places, if they lie between great mountain ranges, and are thus in a double rain shadow; in such circumstances irrigation is necessary for the rearing of the cereal crops and fruits mentioned.

Tropical Desert Type, or Sahara Type.-In the study of climates and the establishment of climatic provinces it was pointed out that near the latitudes of the tropics on the western side of the continents deserts are found, and the circumstances determining them were discussed. It will be remembered that these deserts are found in the track of the trade winds. The study of a rainfall map of Africa or Australia shows how the regions of summer rains gradually pass into these western desert regions as we go farther from the equator. The plant life varies accordingly, and there is usually a gradual passage from summer-rain forests through drier grass lands with scattered trees to semi-desert, and finally thorough desert. The climatic characteristics are, of course, absence or rarity of rain, and a great range of temperature both between day and night and between summer and winter. It will be remembered that the high temperature belts are found in these desert regions (see again Temperature Maps of the continents). A great deal of the surface of these deserts is covered with sand dunes, with, of course, very little vegetation; but wherever subterranean water is available, or where 
there are rare and uncertain rains, are plants which are adapted to the very trying conditions. The seeds are hard and dry, and will live for years in the dormant condition. Some of the plants themselves are hard, dry, and leathery; and the leaves are often coated over with wax, or resin, or gum. These plants are adapted to the excessively dry climate; many are apparently dead, but spring into rapid, vivid life when an occasional shower of rain comes to revivify them. The leaves are necessarily small, so that there is little loss of moisture by transpiration, and the roots go down to astonishing depths in search of ground water. Some plants survive by means of bulbs or tubers, which are buried in the ground, of course, and in which water is stored. In some parts of the desert, especially in depressions between the long barren ridges, a well may give a permanent supply of water and a fertile oasis may result. Or a river may come from distant snowclad or rainy mountains and may bring life to a narrow belt of country which would otherwise be hopeless desert. The Euphrates, the Indus, and especially the Nile, thus make long fertile belts in the deserts, and show the natural fertility of the soil when supplied with water under the hot sunshine. In these oases and in these hot alluvial valleys palms grow to perfection, and under their shelter cereals such as maize, wheat, and barley, peas, beans, and lentils, and tropical and subtropical fruits, are grown. The date, fig, orange, lemon, pomegranate, melon, and olive are some of the betterknown fruits produced under these conditions.

Deserts of this type occur in Mexico and the southwestern States of U.S.A., in South America (where the desert of Peru resembles that of Mexico and Lower California), in north Africa and Arabia, in south Africa, in north-western India, and in Australia. It will be 
noticed that the deserts extend beyond the tropics in both hemispheres, and gradually give way to more fertile conditions in latitudes $25^{\circ}-35^{\circ}$.

Intermediate Tropical Types.-It is to be expected that the transition between the types described above will not as a rule be abrupt; intermediate modifications connect, for example, the summer rain type and the semi-desert type. The dry season gradually lasts longer, and the annual rainfall comes in a much shorter time and is far less in amount. There are two modifications which deserve especial mention; the savana type and the tropical thornwood type. The latter is the drier and merges into semi-desert, having seven or eight months of dry weather and a wide range of temperature. The former is hotter and has more rain, but the conditions do not produce forest growth.

The Savana is typically developed in South America, north and south of the great forest belt of the Amazon. It is also found in Africa, both north and south of the equatorial belt, bordering the Sahara and the Kalahari. A modified savana divides the rainy belt of north and east Australia from the desert interior.

In Africa, east of the Congo basin, a belt of plateaux stretches from the northern to the southern tropic. The equatorial forest is only developed in the river valleys; the plateau land is too high for the dense forest growth normally found in those latitudes. The vegetation is therefore of the savana type, and the southern Sudan may be taken as an example. The grass grows in clumps or tufts, reaching from 6 to 15 feet high, and between the tufts are patches of bare, dry soil. It is thus a grass land in the main ; but here and there are patches of trees, increasing under favourable circumstances, such as in the valleys, to the dignity of forests. The savana may thus be described as tropical park land. 
The savana is suitable for cattle-rearing; the plains of the La Plata basin are among the most famous cattle regions in the world. Cotton, sugar, coffee, and tropical fruits such as the banana and pineapple are the typical crops. Cotton is being grown on the irrigated and naturally-watered parts of the Sudan in increasing quantities. Rice succeeds well in the lower part, where there is obviously an approach to the wetter conditions. Maize, wheat, and barley are grown, often by the aid of irrigation.

The Tropical Thornwood type of Brazil and some parts of east Africa is mostly barren and useless, and can only be made available for man by boring for water and subsequent irrigation. Maize, sugar-cane, and cotton are now grown in reclaimed parts.

\section{Warm Temperate Lands}

These lie, broadly speaking, between the tropical deserts and about $45^{\circ}$ latitude, but of course there is no hard-and-fast line. As before, four main types may be distinguished :

(I) The Western Warm Temperate, or Mediterranean Type.

(2) The Eastern Warm Temperate, or China Type.

(3) Warm Temperate Plateaux.

(4) Warm Temperate Continental Lowlands.

Western Warm Temperate Type - Mediterranean Type.-The climate of the Mediterranean region was discussed in the last chapter; it is the climate which largely determines the character of the vegetation. The dry warm summers and the mild rainy winters are the dominant features of the climate, and the plant-life is adapted to these conditions. The winters are mild enough for plants to continue in bloom where growth would be suspended in winter farther from the equator. 
The vegetation is at its best in spring, when very rapid growth takes place in many plants whose activities are to be suspended in the hot, dry summer. After this comes the summer, which is the period of comparative desolation; the grasses turn brown, the plants with bulbous roots die down, and the seeds of annuals lie dormant until the autumn.

The forest trees vary with the rainfall; where it is wetter, walnuts and chestnuts are common; but in the more typical Mediterranean lands, where it is drier, evergreen oaks and similar trees occur in scattered and open glades.

To survive the trying summer drought the trees have hard polished leaves, or small spiny ones. In most cases they are evergreens, with small leaves either so specially protected that they will not lose much moisture in the summer, or evergreen so that they may take in carbon dioxide during the winter. Many of the plants have hairs or spines on their leaves, no doubt as a protection against grazing animals, especially the goat. Lavender, rosemary, laurels, and brooms are typically Mediterranean shrubs, all specially adapted to live through the trying dry season.

The holm oak of the Mediterranean is an evergreen for the reason mentioned above; there are other devices to prevent excessive loss of moisture due to perspiration; the wood of one kind of evergreen oak is protected by the thick bark with very close pores which is so well known and widely used under the name of cork.

Evergreen conifers with needle-like or scaly leaves are among the important trees of Mediterranean regions. The famous cedars of Lebanon are of course within the eastern Mediterranean province. The forests of cedar and fir in California are also well known. The Californian "redwood" pine is a characteristic tree. The 
giant firs of Washington and California are other examples; these celebrated big trees belong to species of the genus Sequoia, different from the Californian redwood fir. The giant eucalyptus trees of Australia occur in similar latitudes, though not under Mediterranean climatic conditions only.

The grasses of the Mediterranean climatic regions are not the rich succulent grasses of the wetter cold temperate regions; hence cattle are not reared in anything like the same number. Some of the grasses are much sought after for paper-making and for plaiting into baskets and bags; the best known are the esparto grass of Spain, the alfa grass of North Africa, and the delta grass of the Rumanian lowlands.

The cereals do well in the Mediterranean regions, especially where sufficient water is supplied by irrigation, maize, wheat, and barley being grown in large quantities. These regions are perhaps most famous, however, for their fruits, which include fig, orange, lemon, apricot, and peach. The vine is everywhere cultivated and its products as grapes, raisins, or wine are among the most important sources of wealth. The olive tree is the most characteristic tree of this climate; its deep roots, its small, evergreen leaves, and its gnarled trunk, branching low down, are all adaptations to the hot summer and the mild rainy winter. Olive oil is therefore a characteristic product also, and plays the part taken by butter in cold temperate regions, in addition to many other uses. The mulberry is also common, and silk is therefore one of the important products.

All the regions which have the characteristic Mediterranean climate now produce many of these plants; and there has been a remarkable interchange of useful plants. The Mediterranean itself, California, Middle Chile, South Africa, and South Australia all contribute 
a quota of these characteristic plants to the wants of man. For example, a Victorian fruit farmer whose fields are fertilised by irrigation from the Murray may produce Mediterranean oranges and lemons, Californian apricots, and raisins dried from the grapes of vines introduced from Europe. The prickly pear of California is now very common in southern Europe. The sumach shrub of Sicily-so important in dyeing and tanning-has been successfully introduced into South Africa; and many similar examples from the plant world might be given. The mohair goat of Asia Minor thrives in Cape Colony, and its wool or hair is now an article of export from that colony.

Eastern Warm Temperate Type-China TypeThe lands of this climatic type receive summer rains, and the winters may be dry and cold ; thus the climate is often somewhat extreme, though, as was pointed out in the last chapter, there is great variation in this respect. The forests contain many plants of great value. The yellow pines from the South Atlantic and Gulf States, the Georgian white pine, the Virginia cypress, the walnuts, chestnuts, magnolias, sycamores, and oaks are some of the valuable trees. There is a certain amount of overlapping between the Mediterranean and China type, but the forests of the latter are richer.

Among shrubs and smaller trees of economic importance are kauri gum, camphor, cinchona, yerba maté (Paraguay tea), tea, and the mulberry. Cereals include maize, wheat, and millet; sugar-cane, rice, indigo, tobacco, and the opium poppy are other plants which are produced in these lands. The bulk of the cotton of the world is grown in the south-eastern United States, which are typical eastern warm temperate lands. Ramie fibre, the fibre of a nettle, is a product of these 
warm-temperate lands. It seems likely to become a more important textile fibre in the near future.

Warm Temperate Plateau Type.-As we pass from the eastern Mediterranean across the plateau of Asia Minor to Persia we pass from the typical Mediterranean to the plateau modification. The rainfall is usually much less and the climate is extreme. Forests only occur in the occasional valleys, and even there vegetation is not very luxuriant. Irrigation from mountain streams is relied on to give fertility, and cereals, cotton, tobacco, and such fruits as the peach, fig, apricot, and almond are grown. Maize has been grown very successfully on the plateau of Utah by careful use of surface moisture, and the experience gained there is being applied in South America, Africa, and Australia.

This type includes : the Iran Plateau, Asia Minor, parts of Arabia, the southern Kalahari Plateau of South Africa, the High Veld, the Great Basin of North America, the higher Mexican plateau north of the tropic, the higher lands of Argentina, and the plateau of Central and West Australia. Much of it is obviously desert and very slightly productive.

Warm Temperate Lowland Type-The Pampa Type.This has essentially a low rainfall, with a very extreme climate. It passes in most of the continents gradually into the cool temperate lowland type. Taking the warm temperate and cool temperate lowlands together for convenience, and remembering that the summers of the former are often very hot, we may note that these are the dry grass lands of the temperate zone. There is usually a severe and dry winter with a mild and moist spring. The vegetation is uniform over great distances, and forests are rare. The tougher, drier grasses can stand the dry, warm summer, and are different from the grasses of such regions as Britain. 
The soils are not necessarily poor, but the rainfall is too scanty for timber growth; with the help of irrigation, maize, wheat, barley, and beetroot can be grown, maize only in the warmer parts however. Stock-raising is the great source of wealth on the drier parts. The prairies of North America, the Pampas of South America, the Steppes of Russia, the Veld of Africa, and the Great Karoo are the typical temperate grass lands. The High Veld is a high plain, and passes into the warm temperate plateau type.

\section{The Cool Temperate Lands}

It is again possible to distinguish four types of plant associations broadly, but it will be noticed that the differences between warm temperate and cool temperate marginal lands is more pronounced than that between the continental lands of these types. The four divisions are :

(I) The Western Cool Temperate Type-British Type.

(2) Eastern Cool Temperate Type-Laurentian Type.

(3) Cool Temperate Plateau Type.

(4) Cool Temperate Lowland Type.

The cool temperate lands form a belt across the northern continents, but in the southern hemisphere only the extreme south of South America, Tasmania, and South Island, New Zealand, fall within this group. There are no African cool temperate lands except those due to elevation. The characteristics of all these lands are cool summers, and cool to cold winters. There is a great difference in seasonal range between the marginal lands and the lands distant from the sea, and the greatest ranges of temperature known occur in the lowlands of cool temperate type. 
Western Cool Temperate Type-British Type. - This is characterised by mild winters and cool summers, and prevalence of westerly winds. The range of temperature is low, not more than $25^{\circ}$ to $30^{\circ}$, and rain falls at all seasons (page 219). There are no deserts possible under such conditions. We need to consider only the forests and grass lands. There are two types of forests, the deciduous and the coniferous. The former occurs in the warmer, milder parts where the winters are not so cold. The trees resist the winter by shedding their leaves. The commoner trees are the oak, beech, ash, sycamore, horse-chestnut, elm, and lime, and the smaller shrubby trees such as the willows, aspens, alders, and rowans, which flourish under less favourable circumstances than the larger deciduous forest trees. Where the winters are colder the deciduous forest gives place to the taiga or coniferous forest. This occurs on the higher lands and towards the interior. The coniferous forest occurs on all the highlands of central and western Europe, and stretches across Eurasia as a belt, narrowing in the middle of the Continent between the tundra and the steppe of the continental interior. It also covers vast areas in North America. It is essentially a sub-arctic forest adapted to a cold and moist climate. The wealth of timber obtained from both deciduous and coniferous forests of the western cool temperate region is very great, and a vast lumbering industry depends upon it in Scandinavia, Western Russia, and British Columbia. From the coniferous forest, in addition to timber in various forms, wood-pulp for paper manufacture, acetic acid, wood-alcohol (impure methyl alcohol), and wood tar are obtained in enormous quantities.

Eastern Cool Temperate Type-Laurentian Type. -As was explained in the last chapter, this is 
characterised by cooler winters and by a greater range of temperature. The coniferous forest comes down to lower latitudes and the deciduous forest trespasses on the warmer eastern type. Thus the limit of coniferous forests at the sea-level is lat. $45^{\circ}$ in eastern North America, but is lat. $60^{\circ}$ in Scandinavia. The taiga of the St. Lawrence basin has nourished a vast lumbering industry for a long time now ; the corresponding taiga of the Amur has not been so much worked; it still contains untold timber wealth.

Cool Temperate Plateau Type-Altai Type-This is represented by the higher lands, such as Scandinavia below the snow-line, the higher parts of the Variscan European mountains, the Altai in Asia, and the Rocky mountains and Cascade mountains in North America, always, of course, well below the snow-line. From above downwards the high mountains have snowclad summits and upper reaches above the snow-line, below this vegetation of the tundra type, then grass lands followed by the taiga. We may take the mountain taiga and the mountain grass lands as the natural vegetation of the cool temperate type.

Cool Temperate Continental Lowland Type-The Siberian-Saskatchewan Type (see remarks on Warm Temperate Lowlands).-This also contains a belt of taiga, merging into prairie or steppe in the middle of the continent or southwards. Where the rainfall is suffcient or the evaporation is checked by the low mean annual temperature, the taiga is developed; in the drier regions, and consequently where the seasonal extremes of temperature are greater, the forest gives place to grass lands, as in European Russia, Siberia, and Canada. Such lands do not occur in the southern hemisphere.

The cultivated vegetation of all these cool temperate 
lands may be taken together. Wheat may be cultivated almost throughout, except $(a)$ in the colder northern parts, $(b)$ in the wetter extreme western parts, and (c) in the driest parts of the continental interiors. Barley and rye are also extensively grown, the latter being the main crop in the less fertile regions. Maize is not grown, as it requires a warmer summer. Potatoes for food, for starch, and thus indirectly for alcohol, are an important crop, and the beetroot now supplies enormous quantities of sugar. The tree-fruits, apples, pears, and various kinds of plums, are grown in very large quantities, as are the berries, such as gooseberry, red and black currants. Raspberries and strawberries may be grown almost throughout. The drier parts are given over to stock-rearing, being too dry for cereals, or beetroot or potatoes.

\section{ARctic Lands}

There are two different structural types, arctic lowlands and arctic highlands. The latter may at once be dismissed, as the vegetation is negligible. Arctic lowlands are known as tundra, and are found in Northern Eurasia and the extreme north of America. There is a long severe winter and a short summer, in which daylight is almost continuous, but the intensity of the sunlight is of low value, as it falls upon the land at a low angle. The plains are buried in snow for much over half the year; thus with the coming summer the surface only is thawed and shallow-rooted plants begin to grow. The ground is permanently frozen at a depth of a few feet. The only vegetation consists of mosses and lichens, with here and there dwarf bushes of crowberry, willow, birch, and bilberry. In favoured places, in the short summer, brilliantly coloured flowers burst into life in July; these include geraniums, willow herbs, 


\section{PLANT GEOGRAPHY}

and saxifrage. Trees are almost unknown, and there are no vegetable products of economic importance. Observers in the temperate zone may readily study the tundra characteristics on the mountain slopes above the limits of coniferous forest. This "alpine tundra" is well developed in the Alps and Pyrenees, and there are small patches of it in the higher, wilder moors of Britain, and in Canada and in the United States there is a well-defined zone on the western mountains, below the limits of perpetual snow.

\section{BIBLIOGRAPHY}

See end of Chapter XV. 


\section{CHAPTER XIV}

\section{PLANTS AND PLANT-PRODUCTS OF ECONOMIC IMPORTANCE}

IN this chapter the geography of the more important plants will be discussed, together with those immediate products derived from them which are of considerable economic importance. This will again involve repetition, but there is some advantage in emphasising the plants themselves rather than the plant associations as was done in the last chapter.

\section{Food Plants}

There are obviously several divisions or classes of food plants, the most important being undoubtedly the cereals, and these will be discussed first.

\section{THE CEREALS}

These are cultivated grasses, the seeds of which are either eaten whole, or which yield flour or meal or other food-products. They have undoubtedly been developed in their present form by man from " wild " grasses, most of the fundamental development having taken place before the dawn of written history. Seeds of the more important cereals have been found in some Neolithic dwellings; and we also know that at the very dawn of Egyptian history (possibly the oldest history we 
know) the art of growing and using the cereals was well known. Those of importance are wheat, barley, oats, rye, maize, millet, and rice, and they will be discussed in the order named.

Wheat is the most important food grain, for from it is obtained the best flour, that is the flour which yields the most nutritive bread, as well as other valuable food-products. It is essentially a temperate climate grain, and its cultivation was first developed in all probability in warm temperate regions. It requires a moderately heavy soil-that is, a clay or a loam by preference-spring or early summer rains, and a fair amount of sunshine, and at least a fairly dry summer. It is grown in some part of every country which has a temperate climate, but there are now certain regions of the world which produce very large quantities. The thickly-peopled manufacturing countries of western Europe do not grow nearly sufficient for their needs, hence there is a considerable import. Especially is this the case with Great Britain, which has grown only about 30 per cent. of its needs; but it is also true in a less degree of France, Belgium, Holland, and Germany. The best wheat-lands in Britain are in the East Anglian district and in parts of the south-east Midland Clay Vale and the Fenlands. France grows large quantities in the Paris Basin, the Biscay Basin, and the Rhone Valley. The Plain of Hungary, the Lower Plain of the Danube, and the Black Earth region of Russia yield enormous quantities. The Nile Valley produces wheat as a "winter" crop, and it is largely grown similarly in the lower valley of the Indus and the Punjab. Victoria and South Australia grow increasingly large quantities. The largest wheat regions of the world are, however, the middle plains of North America and some parts of the plain of Argentina. 
In North America, the States of Kansas, North Dakota, Minnesota, Nebraska, Illinois, Indiana, Missouri, Ohio, and South Dakota are the chief wheat-producing states of the United States. Washington in the north-west also produces large quantities. In Canada, Saskatchewan, Manitoba, and Alberta and Ontario are the great wheat-producing provinces, in the order named. The world's output of wheat in bushels was as follows (in round numbers) in I9I2 :

Russia, 720 million bushels; United States, 700 ; India, 360; France, 320 ; Canada, 220 ; Hungary, I80 ; Italy, I70; Argentine, I70-the world's total, 3600 millions. ${ }^{1}$

It has been already mentioned that wheat is grown as a "winter" crop in Egypt and India ; it is harvested in Egypt in about April and May, in the Punjab in March, and in the Lower Indus district in February. The harvest in countries in the southern hemisphere comes, of course, towards the end of their summer ; in January and February in Australia and the Argentine. In the northern hemisphere it is harvested in May and June in the north of Africa and in China and Southern Japan; in June and July in the Mediterranean peninsulas, in July in Hungary, Rumania, and Southern Russia, and in August and September in England, Ontario, and Central Russia. It will be seen that wheat is being harvested somewhere at almost every time of the year, so that the import of it to Western Europe could be almost continuous.

It will be necessary to mention only very briefly the very numerous preparations of wheat other than

1 The reader will understand that these figures do not' represent the present output (1919). The Great War has upset everything of this kind, and it is yet too soon to attempt figures for a new adjustment. This applies to many other statistics given in this book. 
flour. Macaroni is made from wheaten flour in Italy and the south of France. The flour is worked into a dough with water and forced through gauges, just as in pipe-drawing. Vermicelli is very similar, but is made into smaller rolls. Macaroni and vermicelli are made from hard varieties of wheat grown in Italy and the other Mediterranean lands, and also imported from India. There are numerous "pastes" made in Italy from wheaten flour ; the latter being made into dough, rolled out into thin sheets, and then cut into small pieces. Many preparations of wheat are now in vogue from Canada and the United States, most of them being put on the market under fanciful trade names, such as "Force," "Grape Nuts," etc. An immense trade is now carried on in these partially cooked or otherwise prepared foods. ${ }^{1}$

Barley.-This cereal is grown over a wider range of climate than any of the other grain crops ; for example, excellent barley is produced in the plains of NorthWestern India, and it is also grown as far north as $70^{\circ}$ north lat. in Norway. This is not essentially a breadcrop ; it is mostly grown to be made into malt, which is used in the brewing of beer. The barley grains are allowed to sprout; at this stage the starch in the grain has been largely converted into sugar; then the grain is killed by heating. The sugar in the malt splits up into alcohol and carbon dioxide in the process of fermentation. The greatest barley producing countries of the world in I9I2 were: Russia, 440 million bushels ;

1 About 200,000 cases of prepared cereal foods were imported to Manchester in I9I2 from the United States alone. These included: "Quaker Oats," " Force," "Grape Nuts," “ Hornby's Oats," " Moloscuit," " Flaked Oats," " Shredded Wheat," " Triscuit," and " Flaked Maize." Manchester is now a great distributing centre (for these foods) for the North of England and the Midlands. 
United States, 220 ; Germany, I40 ; Japan, 92 ; Hungary, 72.

Oats. - This cereal may be grown in regions where wheat does not produce very well, as it will stand a wetter and cooler climate. Hence it is a more northerly crop in Europe and North America. Oatmeal is baked into oatcake, and is also used for porridge and gruel. Oats form one of the chief fodder crops, especially for horses. Oats are now made into various prepared foods, and in these forms are now sold in immense quantities. The chief countries where oats are grown are the following, in the order named: United States, Russia, Germany, France, Canada, United Kingdom, Austria. In the United Kingdom the weight of oats produced is almost equal to that of wheat and barley together. Scotland and Ireland produce far more oats than wheat, the climate being more suitable for the former crop.

Rye.-This is essentially a northern cereal also, and is grown on poorer soil than wheat or barley. It will also endure considerable extremes of climate. Very little rye is now grown in the United Kingdom, though bread made from it was quite common among the poorer classes in the early part of the nineteenth century. It is cultivated in the poorer sandy lands of Holland, Denmark, Prussia, Russia, and Southern Sweden. It is there the chief bread-plant, and the so-called black bread made from it is the chief food of the peasantry. Rye is grown as a fodder-plant, and for the sake of its valuable straw in the United States. Rye-starch is prepared and sold in large quantities as farina.

Maize.-This is the crop always called "corn" in the United States. In the British Isles it is often called "Indian corn." It is a warm-climate cereal, and its cultivation extends more widely into the tropics than the other cereals, but little into the cool temperate lands. 
It will stand neither great cold nor long-continued drought. The climate of the British Isles is not warm and sunny enough; the dry summers of the typical Mediterranean lands are not suitable, except where irrigation can provide considerable moisture for the growing plants. Where it can be successfully grown it is a paying crop, for it is very productive and yields far more weight per acre than either wheat, barley, or oats.

Maize-flour or corn-flour is made from the grain, and is largely used in making blanc-mange, cakes, and puddings. The meal is used for bread in some countries, chiefly when mixed with rye meal. In the United States a favourite dish called hominy-a kind of pudding-is made from coarsely-ground maize meal. The whole grains are often cooked and eaten along with meat, much as the British use peas or beans. The whole heads are cooked and are known as corn-cobs, and are a favourite dish in some parts of the United States. Much starch is made from the grain, and from the starch in turn glucose (a form of sugar) is prepared. This grain is also much used in brewing and distilling.

This is the only cereal which has spread from the New World to the Old, and its name, Indian corn, is a reminder that it was cultivated by the original inhabitants of America.

It is still cultivated in its own continent in enormous quantities, the valley of the Mississippi, with its rich soil and its moderate summer rains, suiting it admirably. It is the great crop of the Central plain, between the wheat belt and the cotton belt. There was twice as much acreage devoted to maize as to wheat in I9I3, and the yield in bushels was more than three times as great. The remarkable part played by the United States in maize production may be seen from a comparison of the 
whole world's output for I9I2, given in quarters of $480 \mathrm{lb}$.

Total for whole world .

United States

Argentina .

Hungary .

Italy

Rumania

$$
\begin{aligned}
& 478,000,000 \text { qrs. } \\
& 370,000,000 \quad, \\
& 32,000,000 \quad, \\
& 21,500,000 \quad, \\
& \text { II,000,000 , } \\
& \text { I0,000,000 ,, }
\end{aligned}
$$

The remainder was produced in Egypt, India, China, Australia, South Africa, and Brazil.

Millet.-This is the general name given to a number of grain-crops used almost exclusively in hot lands. Perhaps the best known are Great Millet or Guinea Corn, and Spiked Millet. The former is called durra in the Sudan, where it is largely grown. Both kinds are very largely cultivated in India as food crops. A species of millet is grown in the southern United States as a green fodder crop.

Rice.-This is essentially the grain-crop of the hot lands. It requires both considerable warmth and plenty of moisture, so that it does well in the hot equatorial lowlands and in the hot monsoon lands. The plentiful summer rains of the latter climatic type in Asia suit it admirably, and that region is, par excellence, the rice land of the world. The rich deltaic lowlands of Bengal, Burma, Siam, and China, and the hot coast-lands are the places where it is grown in greatest quantity. Rice grows with enormous rapidity under suitable circumstances of soil and climate, and it yields a greater weight of grain per unit of area than any other grain crop. Two crops are frequently obtained on the same ground in a year, so that rice provides a large amount of vegetable food in the regions where it is most freely grown. It is significant 
that these rice lands are the most thickly peopled parts of the earth's surface, and it is estimated that probably one-third of the human race uses rice as its chief food-grain.

This grain is not so rich in food value as wheat or oats or maize, and it is significant that the rice-eating peoples do not possess the same stamina generally as the wheat and oats consumers of other lands; but probably other factors than the use of rice as the chief food are concerned with the difference. The Eastern peoples are gradually taking more to other food-grains as they adopt Western ideas in other respects. In addition to the use of the grain as food, much starch is prepared from rice. The straw of the plant makes a good fodder.

Rice is grown under circumstances similar to those of its chief home, in the Southern United States, especially in Florida and near the Mississippi delta, in the West Indies, Central America, in Brazil, British Guiana, British West Africa, and the Sudan. Just as varieties of wheat have gradually been evolved by selection which can stand a wetter climate, so varieties of rice have been evolved which grow in drier soil and in a somewhat cooler climate. The rice grown in drier and cooler lands forms only a very small part of the rice culture of the world, but it has some importance in Egypt and the Plain of Lombardy.

Over 100,000 square miles were under rice in India in I9I3, and the production was about $26,000,000$ tons. The British Isles imported one and a half million pounds worth of rice and rice flour from India in the same year. Siam exported nearly five million pounds worth in the same year I9r3. In Japan, over ro,ooo square miles were under rice in I9I2, and yet that country 
imported over three million pounds worth in that year, and nearly five million pounds worth in rgr3. The Japanese imports mainly came from the more thinly peopled lands of Burma, especially the Irrawadi delta and the lowlands near the Salwen, and from Siam.

\section{LEGUMINOUS FOOD-PLANTS}

There are a great number of plants which have their. seeds enclosed in a long seed-vessel, after the manner of the familiar peas and beans. Those which are used as food for either man or cattle are often termed pulses. The chief are peas, beans, chick-peas or gram, soya-beans, and lentils. All these seeds contain a relatively large proportion of nitrogenous food-stuffs, hence they are valuable foods.

Peas are cultivated throughout the temperate zone, and they will thrive even in the cooler parts. Canada and the United States produce the greater proportion of the peas which are imported into the manufacturing countries of Western Europe. France, Belgium, Holland, Germany, all grow large quantities; in the British Isles they are grown in the Fenlands in East Anglia and the Clay Vale of Aylesbury, perhaps more largely than anywhere else.

Beans.-There are several varieties which are cultivated; some suited to colder climates, some only growing well in warmer lands. The Mediterranean lands produce very large quantities, Egypt alone having nearly Iooo square miles under beans in I9I2. More than half the British import of beans comes at present from Egypt.

Chick-Peas, or Gram, are grown in the Mediterranean lands and in India, where this and other pulses supply the nitrogenous foodstuffs which people in colder regions derive more from animal foods. Gram is one 
of the chief articles of diet in Spain, and the Spanishspeaking countries of Central America also grow some quantity and import a good deal from the Mediterranean.

Soya-Beans are chiefly grown in the monsoon countries of S.-E. Asia, Japan, China, Java, India, all growing considerable quantities. They are constituents of many Eastern dishes, along with grain and other pulses, and they are imported into Britain and the United States for the making of soups and sauces.

Lentils. - These are grown in the same regions: the Mediterranean countries and India, especially in the latter country, where again large quantities are consumed in place of animal food. Lentil seeds are considered very nutritious. Soups are commonly made from them in the cool temperate countries.

\section{ROOT-CROPS}

The chief of these used in temperate countries as food are the turnip, swede, and carrot. The Turnip is probably a native of Europe, but its cultivation has spread into all the temperate lands. It was known to the Greeks and Romans, it spread through Northern Europe in the Middle Ages, and was probably introduced into the British Isles in the sixteenth century. There are now several varieties which have been developed to suit different soils and other conditions. Like the other roots, it has not a high food value, but it is considered valuable as an anti-scorbutic.

The Swede, or Swedish turnip, is cultivated very largely on the continent of Europe, and in North America, where it is known as Rutabaga. This is the most valued of the turnip family, as it is not only more hardy but more nutritious than the common kinds of turnips. Both the turnip and the swede are grown in the rotation. of crops, usually following the wheat crop. 
There are two chief varieties of Carrots, the orange and the large white variety. The orange carrot is the favourite in the British Isles, but the white and light yellow varieties are largely grown on the continent of Europe. These three root-crops are used as vegetables, and also as fodder crops. Turnips are often eaten on the land, the sheep or cattle being confined by hurdles to a limited piece of ground. All three contain a relatively large quantity of sugar, but very little nitrogenous matter.

Beet.-There are several varieties of beet which are cultivated in temperate regions. They have all broad leaves and long tap roots. Mangel-wurzel, or mangold, is one which is grown as fodder for cattle in the sunnier parts of the British Isles. The sugar beet is grown over a wide range in temperate regions in Western and Central Europe, in the United States, and in Southern Australia. Attempts have been recently made to grow it in the. British Isles. About 90,000 square miles were under sugar beet in Europe in I9I3, the leading countries being Russia, Germany, Austria-Hungary, and France, in the order named. Russia had almost one-third of the whole and produced over two million tons of sugar. In England there were I6oo acres only, so that it is still in the experimental stage in this country.

Potatoes.-The potato is not a root, but an underground tuber; still, it may be conveniently studied at this point. It is one of the plants which the New World has given to the Old, and its cultivation is now very widespread. It is a plant suited to the temperate zone, and it thrives well in such different localities as Ireland and the Prussian plains, the one with a considerable rainfall and low range of temperature, the other with a low rainfall and a comparatively wide range. 
There were a little over I,I00,000 acres (over I700 sq. miles) under potatoes in the British Isles in I9I3, almost equally divided between Great Britain and Ireland, and the production reached over 7,000,000 tons. In the United States there were a little over three times the British area given over to this crop. Canada had roughly half a million acres under potatoes in the same year, Ontario leading with one-third of the total area. Germany had 8,500,000 acres (I3,000 sq. miles), that is nearly eight times the British area. The Russian area was almost exactly the same as the British. As is well known, potatoes are much in demand as a food, and they are also much used for the production of starch, and from the starch a good deal of sugar is made, and from this in turn large quantities of alcohol known as "potato spirit." "Brandy" is now largely manufactured from this source. The starch and spirit industries are most important in Germany and Holland.

\section{OTHER STARCHY FOODS FROM TROPICAL REGIONS}

It has already been mentioned that starch is obtained from potatoes, rice, and maize. All the cereal grains contain starch, but it is prepared from rice and maize more than from wheat and rye, and very little is prepared from oats. The starch in these plants, is, of course, a valuable part of the food they supply. The mention of starchy foods leads to the consideration of certain other products from tropical regions, whose principal food-stuff is starch.

Sago.--This is obtained from the pith of various species of palm, all of which grow in equatorial regions. The "sago-palm" of Malaysia is the best-known and most important. This grows in the equatorial lowlands, and yields a large supply of food with remarkably 
little labour. The trees are felled and split, and the starchy food washed out from the central parts. The demand for sago has led to the systematic cultivation of this palm, and plantations of it are now worked in Borneo and equatorial South America. The British Isles imported $£ 260,000$ worth of sago from Singapore in I9I2. That port does most of the transhipping for all the trade of the Malay Peninsula and Borneo.

Tapioca.-This is prepared from the tubers of the tropical manioc or cassava plant. The plant is a native of Brazil, but its cultivation has now extended throughout most of the equatorial lowlands. The tubers contain hydrocyanic or prussic acid in their original condition, and require to be washed with water, pressed and heated to get rid of that poison. The granular meal derived from them after this treatment is the tapioca of commerce ; if prepared in a slightly different way it is known as cassava powder. Both are staple articles of food in tropical regions, especially in Brazil. Average tapioca contains about 83 per cent. of starch, and the proportion in sago and arrowroot is not very different. The British Isles obtained $£$ I90,000 worth from the East Indies through Singapore in I9I2.

Arrowroot.-This farinaceous food is obtained from the rhizomes or root-stocks of various tropical plants. Jamaica, Bermuda, St. Vincent, and the East Indies supply the bulk of the arrowroot which comes to the temperate countries of the west of Europe and North America.

\section{THE SUGAR-CANE}

The sugar-cane is a tall grass with stalks reaching ro I5 feet in height and an inch in thickness. It grows under very similar conditions to rice, and its geographical distribution is very similar. It is cultivated 
solely for the sugar-juice obtained from the stem. It is a perennial, and the root-stock sends up fresh stalks each year, when the old ones are cut down. The weight of sugar yielded varies from 7 to 15 per cent. of the weight of the canes. There has been a long and keen competition between the sugar-cane and the beet-root, but it has been by no means confined to methods of cultivation and extraction. Fiscal legislation has played a considerable part. Up to about I886-88 the sugar-cane led, at one time quite easily, but owing to the bounty system on the continent of Europe the beet-root came abreast by about that time and then gradually went ahead. In I 896 the sugar-beet supplied the world with 5 million tons of sugar, and the sugarcane about $2 \frac{1}{2}$ million, that is, the beet-root now supplied about two-thirds of the whole quantity. The bounty system and protective duties, in Central Europe chiefly, seemed likely to kill the sugar-cane industry. Such a keen observer as Prof. Partsch of Breslau (Professor of Geography in the University) saw the possibility of reverses for that artificially built pre-eminence of Central Europe, and his fears have been realised, though not from the source that he feared, namely, the United States. In Igr2 cane sugar had again forged ahead, and now supplied 57 per cent. of the world's supply. The great new contributor was India, with nearly $2 \frac{1}{2}$ million tons. The chief regions are now India, Cuba, Java, Hawaii, the United States of America, Porto Rico, Brazil, Mauritius, tropical Australia, the Union of South Africa, British Guiana, and Fiji. The British Empire supplied 3.3 million tons of cane sugar in I9I2; the world's total was 9 million tons of cane sugar, and $6 \cdot 8$ million tons of beet sugar. Partsch wrote in I903: "In a few years the United States will be the first sugarproducing country in the world, and will be powerful 
enough to set limits to the sugar-trade of other places." So far has this prophecy failed, that the sugar of the United States has not yet reached more than about a million tons from both the cane and the beet.

\section{TEA, COFFEE AND COCOA}

These are essentially products of tropical lands, either equatorial lowlands, tropical savana lands, or lands of summer rains.

Tea is especially a shrub of the monsoon lands of south-eastern Asia. It has been claimed as a native of Bengal, and also as a native of the Chinese Empire. A variety grows wild in Assam, which has been regarded by some as the parent stock from which all the others have been derived.

The Chinese certainly cultivated it largely at an early date and made it known to Europeans, and China is still popularly regarded as essentially the home of the tea-plant. Tea is a hardy plant, requiring much warmth, moderate moisture, and grows best in a well-drained soil. Hence it succeeds best on the hill-slopes in the tropics. Cheap labour is necessary to do the planting, picking, and subsequent handling, and it is chiefly on this account that the cultivation of tea has spread so little outside India, Ceylon, Java, China, and Japan, where labour is cheap.

Tea-cultivation in India and Ceylon has increased enormously within the last half century; and it has been carefully fostered by the Government. Teaplanting has taken the place of coffee in Ceylon, the climate and soil having been found to be especially suitable to the tea-plant. In I882 Ceylon exported less than one million pounds weight; now it exports I90,000,000 lb. Tea-planting has also made some headway in Natal, Central Africa, the West Indies, Brazil, 
Australia, and Mauritius. India, China, Ceylon, and Japan produce the bulk of the world's product. The British Empire produced about 500 million pounds in I9I2, out of a total of about 850 million pounds. The great consumers of the world's tea are the Chinese, Japanese, the people of India, the British (at home and in the Colonies), the Russians, and the people of the United States. The United Kingdom takes not far from half of the whole export of the world. The import of tea into the United Kingdom in I9I2 was valued at over $\ell^{13}, 000,000$; the United States imported about one-fourth of this value in the same year.

Coffee.-The coffee plant is probably a native of north-eastern Africa, from whence its cultivation has now spread throughout the tropics. It is obtained from the beans or seeds, which are enclosed in a seed-pod. A warm and moist climate is essential, without excessive heat; the coffee shrub is therefore often grown under the shade of other trees. Brazil now produces three-fourths of the world's total. The chief region lies between $20^{\circ}$ and $24^{\circ} \mathrm{S}$. latitude, that is, almost on the southern limit of the torrid zone. Rio de Janeiro and Santos are the great coffee ports of the Brazilian coffee lands. The coffee-producing countries of the world are Brazil, the Dutch East Indies, Central America, the West Indies, Venezuela, British India. It may be especially emphasised that coffee was no longer listed as an export of Ceylon in rgr2. The island was once famous for coffee, but in the prosperous years plantations were established rashly, and in unsuitable situations. The ravages of fungi and insects have assisted in the failure, and tea has almost completely replaced coffee as a staple production. The great coffee-consuming countries are the United States, Central Europe, and France.

Cocoa (Cacao).- This is essentially a product of the 
hot equatorial lowlands, and its distribution is more limited than that of tea or coffee. The fruit of the cocoa tree contains a number of closely packed seeds. The cocoa used for beverages is prepared from these seeds. For the successful growth of the cocoa-plant the mean annual temperature should be about $80^{\circ} \mathrm{F}$., and the dry season must be short. It is produced in tropical America in Brazil, Ecuador, Venezuela, Jamaica, and Trinidad ; in Southern Nigeria, the Gold Coast, and the island of San Thomé in tropical West Africa ; and in the East Indian Islands. Ecuador stood first among the countries in I9II, followed by Brazil, the Gold Coast, San Thomé, and Trinidad.

Maté or Paraguay Tea.-This is obtained from the leaves of a small tree or bush which grows in Southern Brazil and Paraguay. An infusion of it is used in South America just as tea is used in English-speaking lands. Prof. Church disparages its use very strongly, as it acts injuriously upon both the nervous and digestive systems.

\section{Fruits}

Fruits of the equatorial region will be discussed first, and then those of cooler climates in succession.

Tropical Fruits.-These are very numerous, but very few of them reach temperate lands. The diffculties of transport are as yet too great. Residents and travellers in tropical lands often attempt to excite the envy of dwellers in cooler regions by descriptions of tropical fruits. The chief of those which do reach countries such as the British Isles are the banana, pineapple, coco-nut, and date.

Banana.-This requires a hot, damp climate. It reaches as far north as Florida and Southern Japan, and as far south as Northern Natal and Southern Brazil. 


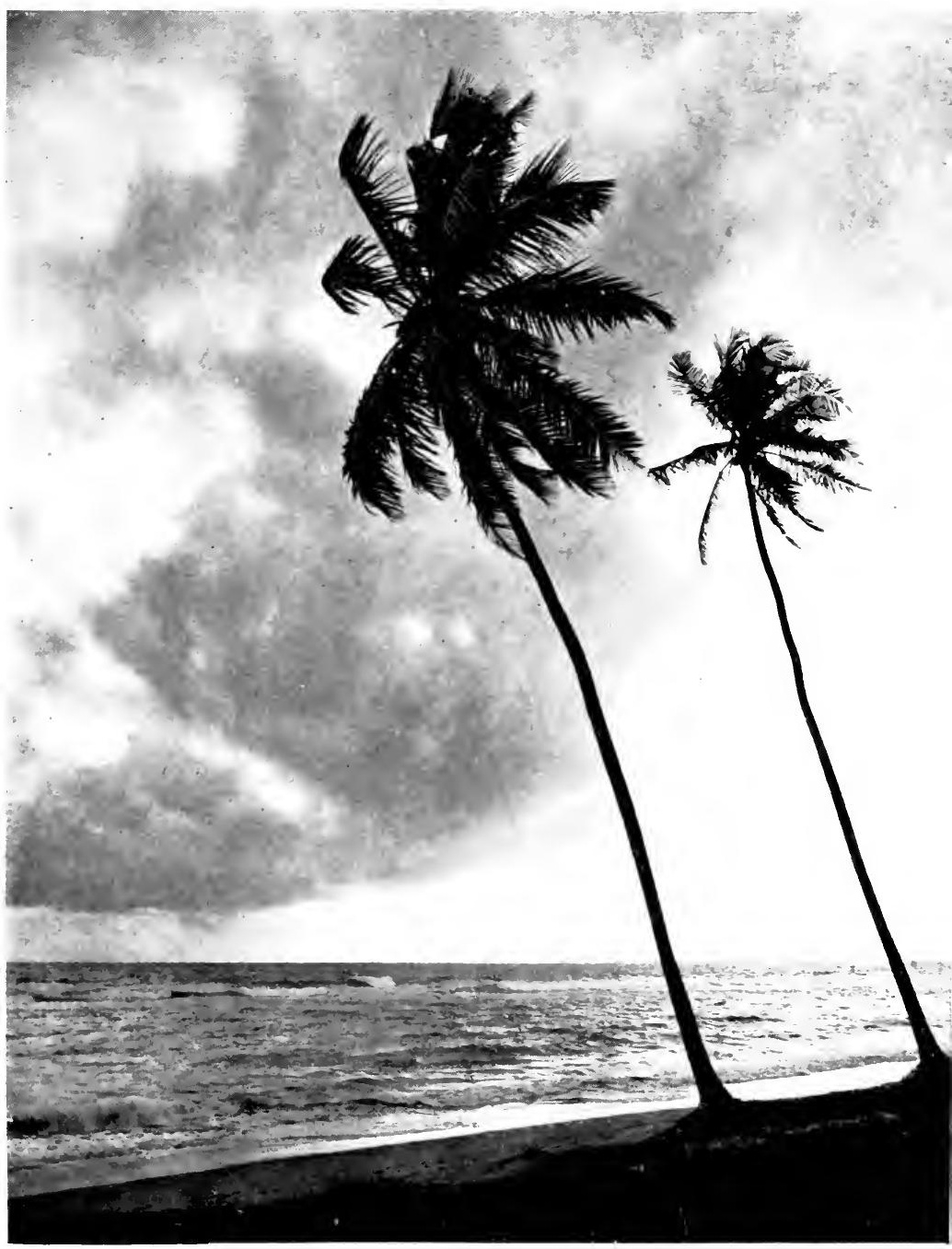

Plate XX.-Coconut Palis, Chylon. 




Plate XXI.-Cotton Picking, South-Eastern United States. 
The West Indies lead in the banana trade, and immense quantities are now shipped from thence to the British Islands, Canada, etc.

Pineapple.-This plant is a native of Brazil, and has now been naturalised in almost all tropical South America, Central America, and the West Indies. It has been successfully cultivated as far north as Northern California. It is now very largely grown in Central America, from which large quantities are sent to Western Europe.

Coco-Nut.-This palm is almost ubiquitous in hot - lands, though it grows most luxuriantly near the sea, and especially on tropical islands. It is almost confined to the torrid zone, and to the lowest 2500 feet or so of the mountain lands of the tropics. Its uses are almost as numerous as the plant is ubiquitous and common. The pith of the stem is used as a kind of sago; and the young green fruit is widely used as a food. But the other uses of the plant are more important than the use of the nut as a food. The dried kernels, known as copra, yield an oil of which enormous quantities are used for burning-oil and in soap manufacture; for lubricating oils and as an cdible fat; the coir or fibres which form the covering of the nut are used for making mats, etc. ; the sugar in the flowers is the basis of palm wine and the arrack (spirit) which is distilled from the fermented liquid ; the timber is used for huts in the tropics, which are often thatched with the large strong leaves. The coco-nuts which come to the British Isles are chiefly from Madras and Ceylon. It was estimated some years ago that at least forty million coco-nut palms were growing on the southern coasts of Ceylon.

Date.-The date-palm is a characteristic tree of the tropical thornwood or caatinga climate, and also of the 
desert. Its range is rather wider than the torrid zone, but its fruit does not ripen in Italy or the Balkan Peninsula. Northern Africa, Arabia, Mesopotamia, Persia, and India are the chief regions for this palm. The chief British imports of the dried fruit are from Arabia and the lands round the Persian Gulf. There are other uses in addition to food, for the timber, leaves, and fibre are much used in the regions where it is grown, and a sweet beverage is made from the sap.

\section{SUB-TROPICAL AND WARM TEMPERATE FRUITS}

There is, as may be expected, a good deal of overlapping of fruits in sub-tropical to tropical and warm temperate region, especially with fruits of the citrus family. Fruits are common in the three types of warmtemperate climate, Mediterranean, Chinese, and Continental, and within certain limits the fruits indigenous to each type have been naturalised in the others. The western type, with its dry summers, is rich in fruits, and a very great number might be enumerated. Only the more important can be mentioned here.

Orange.-This is a native of the monsoon lands of south-eastern Asia; it has been claimed as a native of both India and China. It was probably introduced into China at a very early date, and the Chinese have long cultivated the tree with great care. It was brought from China to south-eastern Europe in the middle of the sixteenth century. It has now spread to many tropical and most of the warm temperate lands. The usual limit of its cultivation is about $37^{\circ}-40^{\circ}$, but it reaches $43^{\circ}-44^{\circ}$ in the north of Italy. The tree is evergreen, and its rich green glossy foliage can survive the dry warm summers. As an illustration of the transference of fruits from one region to other similar climatic regions, the magnificent orange groves of Victoria and 
New South Wales may be instanced. The plants were originally brought from Spain, and they flourish side by side with apricots introduced from California, but which probably came from Armenia originally. Oranges are exported in quantity from Spain, Italy (especially Sicily), Algeria, the Levant lands, the West Indies, southern Brazil, and southern Australia. In I9I2 the United Kingdom imported from Spain alone oranges to the value of $£ 2,000,000$.

Lime, Citron, Lemon.-These are other species of the genus citrus, all characterised by similar fragrant or essential oils in the rird or peel, and all containing citric acid and potassium citrate in the fleshy pulp. They are all grown in warm temperate and hot lands. The citron was the first of the whole citron group to be naturalised in Europe, having been introduced by the Romans from Mesopotamia in the first century. These fruits thrive in the West Indies, from which large quantities of lemons and limes are exported. The island of Montserrat is famous for its limes.

Fig. - The common edible fig is probably a native of southern Turkestan, and its cultivation has long been carried on in the countries bordering the Mediterranean, in Persia and Armenia, and especially in Asia Minor. Smyrna is the chief port of export for figs. They are successfully grown in Greece, southern Italy, and Spain. Large quantities of dried and pressed figs are imported into the British Isles and other cool temperate lands.

Mediterranean Nuts.-Several nuts rich in oil and nitrogenous food stuffs are grown and exported from Mediterranean lands. The best known are walnut, chestnut, filbert, and almond. Almonds are exported especially from Malaga, filberts from Barcelona, chestnuts from several Spanish and Italian ports. These 
nuts are for the most part luxuries in the British Isles, but in the countries where they are grown they are important articles of food. The hickory nut, well known in North America, resembles a small walnut. The last-named and the chestnut and filbert extend into the warmer parts of the cold temperate zone.

The Vine.-This belongs to the warm temperate lands, and extends slightly into the cold temperate regions. Its northern limit is about $50^{\circ} \mathrm{N}$. It thrives best in Mediterranean lands with dry summers, but it also flourishes in the eastern United States. The heavy summer rains of south and eastern China prevent the cultivation of the vine there for winemaking. In Europe, the Iberian Peninsula, France, Germany, Italy, Hungary, and southern Russia are the chief regions for grapes. California, eastern United States, Asia Minor, western South America, Cape of Good Hope, South Australia, Victoria, New South Wales, and North Island, New Zealand are other vine-growing regions. The grapes themselves, grapes sun-dried as raisins, and wines of various kinds are all important products of the vine. Valentia, muscatel, and sultana raisins are dried grapes of varieties from which little wine is made. Currants are small raisins from a variety of the vine grown in Greece and the Ionian Islands.

The amount and quality of the wine obtained from grapes depends upon the nature of the soil, the climate, and, of course, upon the variety of grapes produced. Methods of subsequent treatment of the grape-juice also count very considerably. The result of the natural differences combined with differences of treatment is that almost every region has its own particular kind of wine, and certain kinds have been associated with the names of certain places from time immemorial. 


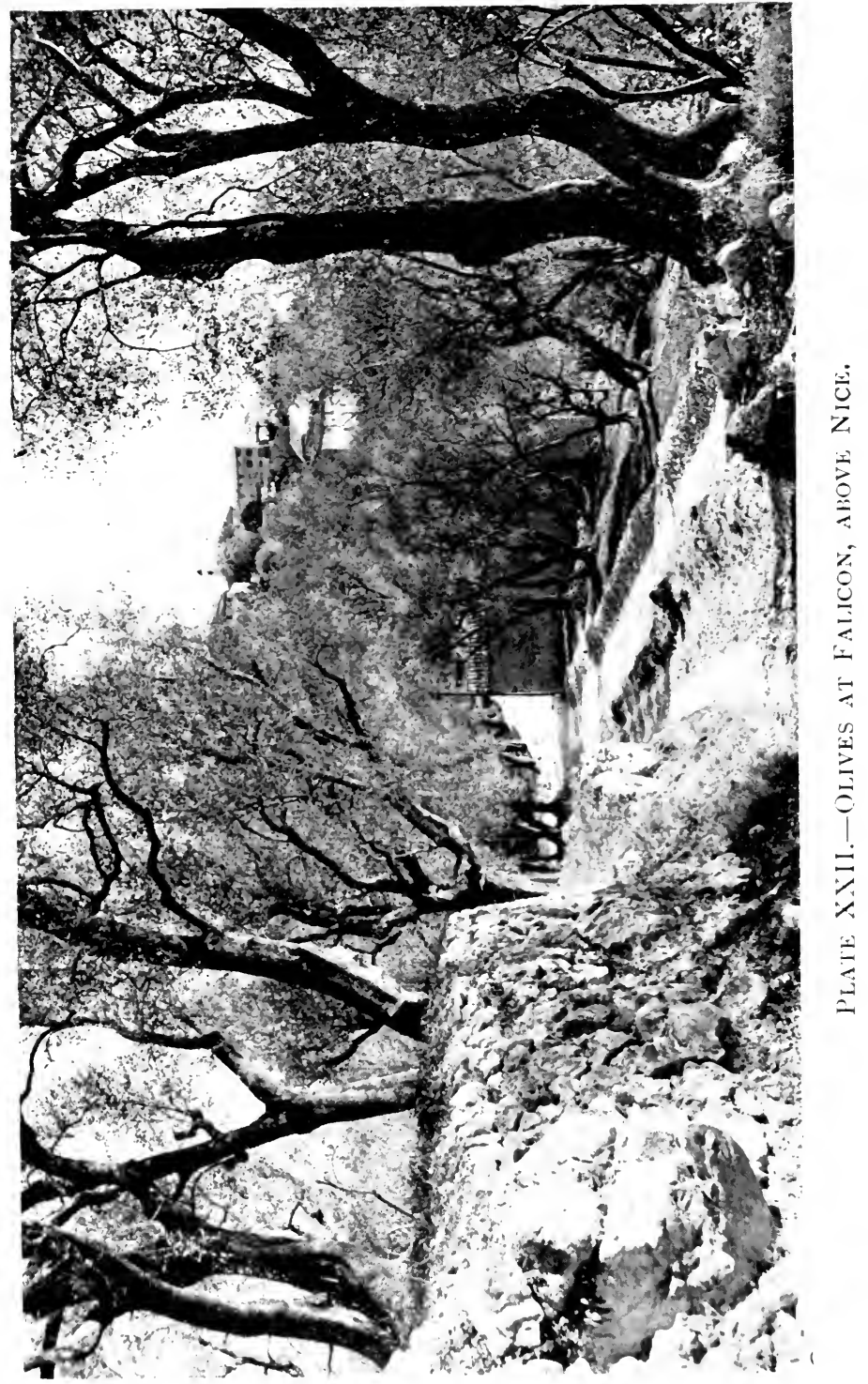




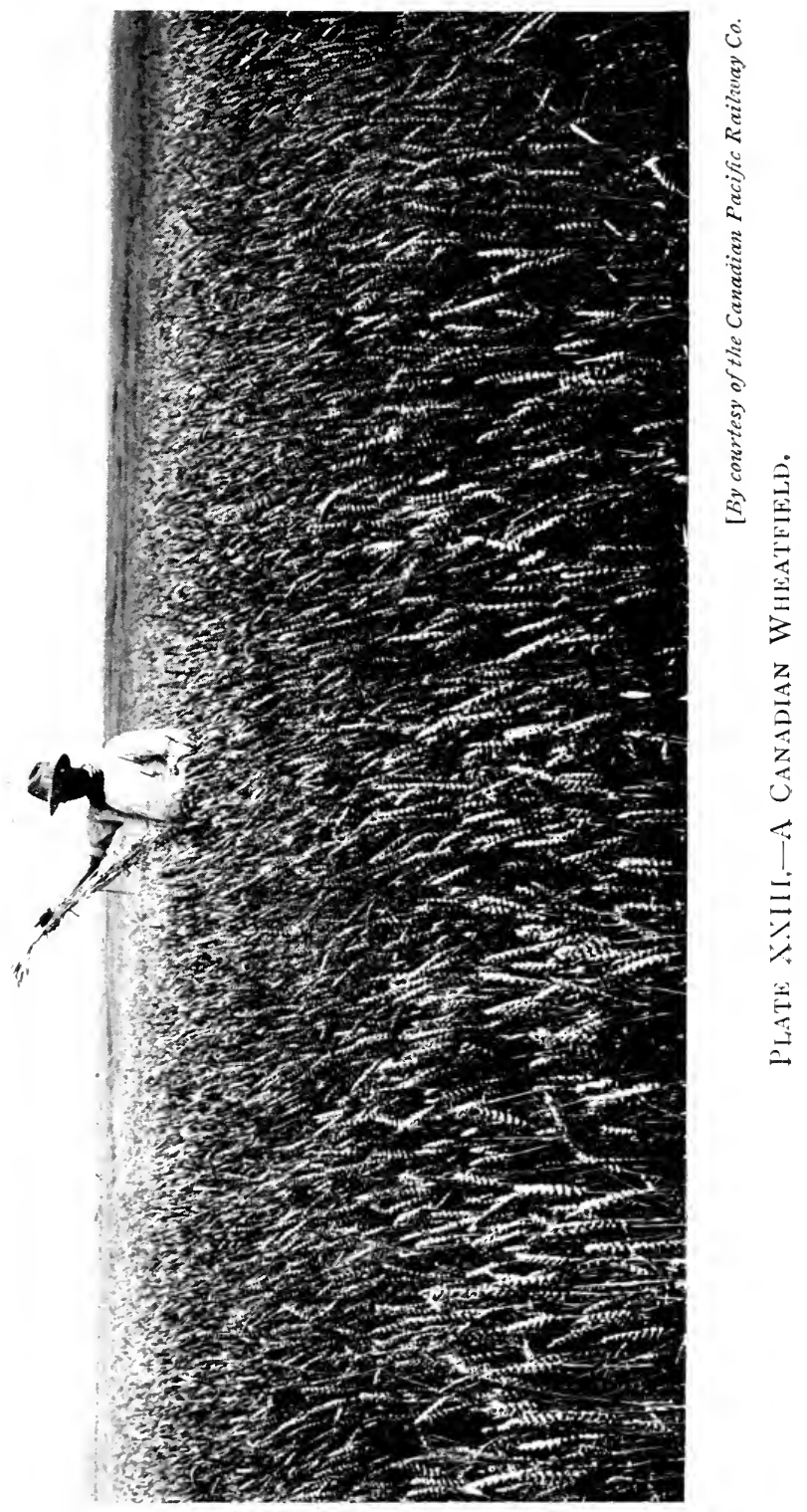


The total production of wine in I9II was three and onethird thousand million gallons; of these, France produced roughly one thousand million gallons, and Italy nearly as much. Spain, Algeria, and Russia each produced over one hundred million gallons. The British Empire produced the comparatively insignificant amount of about fifteen million gallons.

The Olive.-The olive is par excellence a Mediterranean tree. Originally a native, in all probability, of Asia Minor or Armenia, the tree has now spread throughout the Mediterranean lands, except Egypt. The warm dry summers suit it admirably, but it cannot stand cold winters, and hence does not grow well on the open parts of the Plain of Lombardy. Where there is good shelter from the cold north winds it thrives quite well, however, on the lower parts of the southern Alpine slopes.

The tree is cultivated for the sake of the oil which is obtained from the outer parts of the fruit. Olive oil is much used as a table oil, for cooking and preserving, especially in France and Italy, and to a less extent in the other Mediterranean countries. It takes the place of butter in cold temperate countries. Italy is the greatest producer and exporter of olive oil, while France uses practically as much as it grows. The British Isles import it from Spain, Italy, Turkey, Asia Minor, and Morocco. Olive oil is used for soap-making in addition to its use for cooking.

WARM TEMPERATE AND TRANSITION TYPES OF FRUITSAPRICOT, PEACH, PLUM, CHERRY, ETC.

This group of stone fruits extends from the warm temperate into the cold temperate zone, where several varieties of these plums are successfully grown.

Apricots are grown in Northern California, in North 
Island, New Zealand, and Victoria, all of which have the Mediterranean type of climate. The fruit can, however, be successfully produced in France and Southern Britain, but only with special care as to the aspect in Britain. It is thus a transition fruit connecting the warm temperate and cold temperate zones, but thriving best in the former. Its native country is not known with certainty, but the specific name, armenica given to it, from the old Roman name, suggests it came from the country south of the Caucasus, which has given so many useful plants to the temperate zone.

Peach.-This belongs to the same genus as the apricot and plum. The apricot is Prunus armenica; the peach is Prunus persica. The latter name suggests Persia as the native country, but this is by no means certain. The peach is also a transition fruit, but it succeeds in the cold temperate lands rather better than does the apricot. It is grown in France and the southern parts of Britain, but much more successfully in the United States, where it is largely grown and preserved in cans for export.

Plums.-The several varieties of the plum belong to the same genus, and are more essentially cold temperate plants, extending somewhat into the warm temperate zone. Many kinds of plums-greengages, victoria plums, damsons, prunes, etc.-are extensively grown on the continent of Europe and in different parts of the British Isles. Large-sized plums are grown in very great quantities in Serbia, and to a slightly less extent in Bosnia, Bulgaria, and Rumania. Many of these are imported into the British Isles in the dried condition. There is also a large import of plums from France. Plums may be readily preserved, and both in this condition and fresh they form a favourite article of food. 
Cherry.-This is yet another plum, Prunus cerasus, which is grown in both warm temperate and cold temperate lands. The group therefore, which includes the apricot, peach, plum, and cherry, is characteristic of the transition from warm temperate to cold temperate climates, growing, broadly speaking, between $40^{\circ}$ and $60^{\circ}$, though there is considerable difference of latitude in the different regions, as may be expected.

Apples and Pears.-These belong to the same natural order of plants as the plums, and grow under broadly similar conditions of climate and soil. They extend even a little farther into the cold regions, and in Norway apples are successfully grown very near the Arctic Circle. They may, however, be grown in the warm temperate zone both under western, eastern, and continental conditions, though less successfully in the last, as at least a moderate rainfall is required. Both are native in the cool lands of Western Europe, the common crab-apple, the probable parent of all the varieties of apple, being well known as a hedge plant in the British Isles. They. were known to the early Greeks, both being mentioned by Homer. The apple is an exceedingly useful plant, both as a dessert and in many forms of cookery; the many forms in which it is served will be well known to every reader.

These fruits are cultivated throughout the whole range of the temperate zone. Western Europe, including the British Isles, Canada, the north-western United States, California, Victoria, Tasmania, and New Zealand, China, and Japan are the chief producers. Both fruits are imported into the British Isles from the Continent, Canada, the United States, and Australasia. One of the best regions, perhaps the best, is the Lake Peninsula of Ontario, which now produces enormous quantities of excellent fruit (see p. 132). 


\section{SOME COOL TEMPERATE FRUITS}

A number of useful fruits are more nearly confined to cool temperate lands, though their adaptability has led to their extension into the warmer lands to a somewhat smaller extent than in the case of the last group. The red and black currant, the gooseberry, the raspberry, and the bramble or blackberry are well known and useful fruits, essentially plants of the cool temperate lands, and extending somewhat into Arctic regions. The blackberry does not appear to be cultivated very much, though it would probably pay well for such treatment. The strawberry extends from the cooler parts of warm temperate lands right up to the Arctic Circle, the fruit grown in higher latitudes being preferred by many people. The bilberry and cranberry extend well into the Arctic lands, and may be regarded as transition plants from the cool temperate to the Arctic. They even grow under tundra conditions, Arctic tundra as well as Alpine tundra. The fine luscious bilberries, which grow quite close to the snow and ice of the Alps, will be familiar to many a tourist.

\section{OTHER VEGETABLE PRODUCTS}

Spices and Condiments.-Brief mention may be made of a number of food-adjuncts which illustrate the relation of vegetation to climate and soil. Most of the spices come from the hot lands, the monsoon regions taking first place. As examples the following may be quoted: Pepper comes from the Malay Islands and Indo-China, and is collected and marketed chiefly at Singapore. Ginger is produced in the same general regions, where it is native. It has now been introduced into British West Africa and the West Indies. Allspice 
(pimento) comes chiefly from the West Indies, and British West Africa. Cinnamon is produced in the Malay Islands, in Ceylon and the West Indies. Vanilla comes from Mauritius and Reunion and other islands in the Indian Ocean. The Spice Islands (the Moluccas), as their name indicates, produce a number of spices; nutmeg and cloves come from there, and from Java and the West Indies.

Spices played an extraordinary part in the early trade between the East Indies and Western Europe. They were brought both overland to the Mediterranean and thence forward to the north-west, and also round the Cape. The profits often made were enormous, as the spices were bought at very low prices in the Eastern market. Of course the risks were very great, as not only were there the dangers from storms, and from rocks and shoals not mapped, but piracy was then very common.

Tobacco and Opium. - Though in no sense foods, these narcotics may be mentioned at the close of this chapter.

Tobacco.-This is produced from several species of plants of the genus Nicotiana, all of which are natives of America. Though probably of tropical origin, tobacco can be grown over a wide range of climatic conditions. It is cultivated in tropical Brazil, in India and Java; and the recent attempts to grow it in Ireland are well known. It is grown in large quantities between latitudes $45^{\circ}-55^{\circ} \mathrm{N}$. on the continent of Europe. Though of such wide range the tobacco obtained varies considerably according to the conditions of soil and climate.

The United States produced on an average about $I, 000,000,000$ pounds of tobacco per annum in recent years. This is about 40 per cent. of the world's total output. Kentucky, Virginia, and North Carolina are the leading states. The other chief tobacco-growing 
countries are India, Russia, Austria-Hungary, the Dutch East Indies, and Japan. The United Kingdom imported tobacco (chiefly unmanufactured) to the value of $£ 8,000$,000 in I9r3.

Opium.-This is the dried latex of a species of poppy which is extensively grown in Egypt, Asia Minor, Persia, India, the East Indies, and China. The Chinese demand for opium was formerly supplied mainly from India. Both the growth and import are being rapidly diminished in China, the British Government having co-operated by legislation to reduce the contribution from India.

Cinchona and Quinine.-There are several tropical trees the bark of which contains a number of alkaloids; the most important of these alkaloids are quinine and cinchonine. The bark itself is widely used medicinally under the name cinchona bark or Peruvian bark. Quinine and compounds of quinine, such as the hydrochloride, sulphate and some double salts, are freely used in medicine. Quinine is valuable as a medicine in two ways, first as a specific antidote in malarial diseases, probably acting as a poison to the parasitic microorganisms; secondly, as a febrifuge in intermittent fevers. Cinchonine is not so valuable and reliable as quinine. Many attempts have been made to produce the latter alkaloid synthetically, but though its constitution is now understood the production in the laboratory from simpler and cheaper compounds has not yet been achieved. Quinine, therefore, is still obtained from the bark of the various Cinchona trees. These are natives of the tropical parts of the Andes, chiefly those between the equator and the southern tropic. They flourish best on the slopes of the mountains between altitudes of about 2000 to 8000 feet, where rains are plentiful and there is copious sunshine. The trees have 
been successfully grown in many other tropical regions, and supplies of quinine and cinchonine are now obtained from a wide range of tropical lands. Colombia and Jamaica in the Western Hemisphere; the Western Ghats, Southern India, and Ceylon and Java in the Old World are among the more famous localities.

\section{BIBLIOGRAPHY}

See end of Chapter XV. 


\section{PLANTS OF ECONOMIC IMPORTANCE-} (Continued)

\section{Plants other than Foodstuffes}

\section{TEXTILE PLANTS}

Cotton.-This is the most important plant-product outside the foodstuffs, from a commercial point of view; its growth is widespread; its uses so far-reaching. There are three or four species of plants of the genus Gossypium from which cotton is obtained. The seedvessels of these plants are enveloped when ripe by tufts of white woolly fibres. These fibres are easily " picked" from the ripe, opened seed-vessel.

Cotton is grown in almost all tropical and sub-tropical regions, but its cultivation is most successful in the latter, or in elevated equatorial lands. In India, Central Africa, and Brazil, for example, the cultivation is most successful on the plateaux, where sub-tropical conditions, of course, obtain. The different species of cotton plant require a long summer, with moderate moisture, and a low range of temperature. Equable warm temperatures, with no frost, produce the best results. In the United States, still by far the greatest producer, the range of temperature in the three most important months, June, July, August, is $76^{\circ}$ to $82^{\circ}$. There are copious summer rains, which rapidly diminish in quantity inland; and the chief areas of production are 
some distance from the coast. Texas, Georgia, Mississippi, Alabama, S. Carolina, N. Carolina, Arkansas, Oklahoma, Louisiana, and Tennessee are the great cotton-growing states. Florida, for example, produced only 30,000 bales in I9r3 against 4,000,000 bales from Texas. It will be noticed that the dry western plains and the northern states are outside the cotton belt. The limits are roughly $100^{\circ} \mathrm{W}$. and $38^{\circ} \mathrm{N}$. In India, the next great producer, the plant is chiefly grown in the regions fed by the monsoon rains, or in the wellirrigated regions of the north-west. The temperature has a somewhat wider range during the important growing months, ranging from $75^{\circ}$ to $88^{\circ}$. In Egypt, cotton is almost confined to the delta and to those parts of Middle Egypt where water can be freely supplied by irrigation through the seven months of growth. The average temperature at Cairo in the same three important months is from $83^{\circ}$ to $85^{\circ}$. The alluvial soil of Egypt is remarkably fertile, and this, combined with the climatic conditions, causes Egyptian cotton to be of very high quality.

The world's production of cotton amounted in I9I2 to over $22,000,000$ bales of 500 lbs. The United States contributed nearly $15,000,000$ bales; India, 3,500,000; Russia (Turkestan and Caucasia), 2,000,00o; and Egypt, I,500,000. The U.S. yield was very heavy that year; it fell to less than $14,000,000$ bales the next year; while that of India had gone up to 5,000,000 bales in I9I4. China produces a large amount of cotton for home consumption, chiefly in the valley of the Yangtse. The amount produced in China is not known. Great efforts have been made for many years to increase the output from different parts of the British Empire, the British Cotton-Growing Association having investigated conditions of soil, climate, and labour, and carried out 
extensive experiments in many colonies. The British Empire produced about 3,600,000 bales in I9I2, that is nearly one-sixth of the world's known supply. Outside India about half a million bales only were produced. Uganda, Nyassaland, Southern Nigeria, Cyprus, and the West Indies were the chief contributors. The United Kingdom imported raw cotton valued at $£ 7 I, 000,000$ in I9II and $f 80,000,000$ in I9I2.

Flax.-This plant yields a variety of useful products. The inner bark of the stem yields the fibre called linen; the shorter fibres, not long enough for weaving, form tow, which is used for rope and twine-making; the seed (linseed) yields an oil which is largely used in making paints and varnishes; when the seeds are pressed for oil a "cake" is left which is an excellent cattle food, under the name of oil-cake; the seeds when ground form the common linseed-meal used for poultices.

Flax may be grown under widely different conditions of climate. India, the colder parts of central and west Russia, the N.-E. of Ireland, and the Pampas of Argentina, may be quoted as illustrating the wide variety of climatic and other conditions. The plant is grown for different purposes, however, in these different regions. In India, flax is grown chiefly for the seeds, and indirectly for the oil ; the fibre of Indian flax is of little value. In Russia the fibre is the more important product. In the United States the plant is grown almost exclusively for the seed.

The chief regions for the production of flax are India, Russia, the United States, and Argentina. The areas under flax in the countries named, in I9I2, were:

India

Russia .

United States

Argentina
$4,053,000$ acres.

$5,518,000$

$2,851,000$

$4,281,000$ 
In the United Kingdom the average area under flax for the four years I9I0-I9I3 was 57,000 acres, almost all of which was in Ireland.

Hemp. - This plant produces a fibre similar to that of flax, only coarser and stronger; hence it is chiefly used for canvas, sailcloth, and ropes. It is grown over a wide range of climate, as in the case of flax. The three chief countries are Russia, Italy, and India. Russia produces a large quantity, and exported 20,000,000 roubles worth in I9I3. Italian hemp is of excellent quality, that of Piedmont being especially noted. Hemp is grown in India more for the sake of stimulants derived from it, of which the most important is charas, an intoxicating drug.

Jute.-This comes next after cotton and linen among the textiles of vegetable origin. It is a product of hot countries, the monsoon lands of South-Eastern Asia producing the bulk of it. It needs a high temperature and moist conditions. Alluvial soils in the countries named, and in Egypt, where it is grown on the irrigated lands, suit it best. India had over 3,000,000 acres under jute in I9I3. There are several other fibres now produced in tropical lands, all of which are used for much the same purposes as hemp and jute. Manilla hemp is obtained from a species of banana grown in the Philippine Islands; ramie or $r$ hea ${ }^{1}$ comes from a species of nettle originally grown in China, but now grown in India, the East Indian Archipelago, Mexico, and North Africa; henequen or sisal hemp is made from the thick fleshy leaves of an agave grown in Central America and the West Indies.

1 Ramie fibre seems likely to become more important as an ordinary textile fibre in the near future; at present its chief uses are in incandescent mantles, in the making of a special surgical lint, and in cloths made from mixtures of silk, artificial silk, and ramie. 
Silk.-This is treated here because, though of animal origin, its production is dependent upon the mulberry tree. As is well known silk is the material with which the caterpillar of the silk-moth encloses its cocoon. The caterpillar lives on the leaves of different species of mulberry. Silk is therefore produced in regions where the mulberry can be grown successfully. It is essentially a product of the warm temperate regions, both those of the western and the eastern types. The original home is the eastern margin of the monsoon lands of Asia. Silk has been known in China since long before the Christian Era, possibly nearly 3000 years before. It was gradually introduced into Southern Europe by the Romans and afterwards the Arabs; into Italy in the sixth century A.D., and into Sicily and afterwards Spain perhaps in the tenth and eleventh centuries. Its production has obviously gradually travelled westward, and all the lands involved in that passage still produce silk in quantity. Japan has now passed China, ${ }^{1}$ though the latter was until very few years ago by far the leading country, and after these come Italy, Turkey, and France in the order named.

Silk is produced throughout almost all China proper, but by far the greater part comes from the region between $30^{\circ} \mathrm{N}$. and $35^{\circ} \mathrm{N}$. This latitude may be compared with that of northern Italy and the valley of the Rhone, quite $10^{\circ}$ higher in latitude. The milder winters of the western lands, contrasted with the cold winters of China, are responsible for this northerly displacement of the silk zone in the west of Eurasia. The Middle Yangtse valley has an average January (winter) temperature of about $40^{\circ} \mathrm{F}$., which is about the same as that of the Plain of Lombardy.

1 It is said that the present supremacy of Japan is probably transient. 
The production of silk in I $9 \mathrm{I} 2$ was as follows :

\begin{tabular}{|c|c|c|c|}
\hline The Wo & Supply & & $57,000,000 \mathrm{lb}$. \\
\hline Japan & . $\quad$. & & $2 \mathrm{I}, 000,000 \mathrm{lb}$. \\
\hline China & • & • & I $4,500,000 \mathrm{lb}$. \\
\hline Italy & - & • & I0,000,000 lb. \\
\hline Turkey & . & & $5,000,000 \mathrm{lb}$. \\
\hline France & $\cdot$ & & $\mathrm{I}, 000,000 \mathrm{l}$ \\
\hline
\end{tabular}

Other countries producing silk are India, Caucasia, the Tyrol, and the United States.

\section{DYE-WOODS AND OTHER DYE PLANTS}

These have for many years been much less important than formerly, their place having been largely taken by synthetic dyes produced chiefly from the coal-tar hydrocarbons. This modern synthetic chemistry has almost entirely killed the growth of madder, and has adversely influenced the cultivation of indigo. There are now signs, however, that there may be some reversion to the natural products.

Indigo.- This is by far the most important vegetable dye-stuff. The plant from which it is produced is a native of south-eastern Asia, where it is still grown in largest quantity. It has been successfully grown in tropical Africa, tropical America, and even in the regions to the south-east of the Caspian Sea. The dye is obtained from all parts of the plant, which is cut down when flowering begins. The plants are soaked in water and allowed to ferment for some time at about $85^{\circ} \mathrm{F}$., and the solid dye is obtained from the fermented liquid by evaporation. Indigo is exported from India in the form of "cakes." The export from that country is greatest, followed by the Central American republics. India produced 48,000 cwt. in I9I2, and $38,000 \mathrm{cwt}$. in 1913. 
The woad of the ancient Britons produced a blue dye almost identical with indigo. The cultivation of woad declined when the route to India was opened up, though many attempts were made to encourage its growth by restricting the import of indigo.

Madder.-This plant was formerly grown in large quantities in Europe for the production of bright red and yellow dyes. The dye-stuff present in extract of madder was prepared from anthracene, a cheap coal-tar product, in 1868 . Since then the growth of madder has been on a very small scale, but as the vegetable dyes seem to be much more lasting than the synthetic dyes, there is some tendency to revert to the use of madder. Much of the ground formerly under madder has been devoted to sugar beet, the requisite conditions of climate and soil being about the same for the two plants.

Dye-woods.-These are obtained from the heart wood of certain trees growing chiefly in tropical countries. The wood is usually imported into and sold in industrial countries in the form of "chips," the dye being obtained by boiling with water. Logwood is perhaps the most important. It is grown in Honduras, Southern Mexico, and the West Indies. Its dark-red wood yields an extract which is used in dyeing cotton, wool, linen, and leather, giving blue, brown, or black according to the mordant used along with it. Fustic chips come from a tree grown in Nicaragua (Central America); a yellow dye is obtained from it which is frequently used in conjunction with other dyes to give various shades of brown and orange. Brazil-wood, a tree from Brazil, is now grown in other tropical lands, and yields a red dye. A great many other plants yield dyes, but for a fuller trea tment of the subject the reader must consult one of the manuals of dyeing. Scores of 
vegetable dyes are used in India, Siam, China, and Japan, the very names of which are known only to the experts in the subject.

Tanning Materials.-Most of these are products of the vegetable kingdom. Until quite recent years the only inorganic tanning material was common alum (potassium aluminium sulphate), but within the last thirty years chromium salts have come into regular use, and "chrome-tanned" leather has now displaced vegetable-tanned leather to a very considerable extent. Only the more important vegetable tanning materials will be mentioned. Oak-bark is the great tanning material of history, but larch-bark, and hemlock-sprucebark are now serious competitors. Acacia-bark is used in the Southern Hemisphere and is also imported to the industrial countries of the Northern Hemisphere.

Extracts made by boiling oak-wood, chestnut-wood, hemlock-wood, and other woods under pressure with water, are now very widely used for quick tanning. These are all trees of temperate lands. An extract known as quebracho is obtained from the wood of a tree growing in Chile and northern Argentina. It has a high percentage of tannins and is now very widely used for the tanning of cheap leathers for various purposes. Gambier is obtained as an extract from the leaves of a shrub growing in the Malay Peninsula, Java, Sumatra, and Borneo, and is chiefly exported to Western Europe and the United States from Singapore. Like quebracho extract, it has a high tanning value. It produces a very different leather from quebracho, however. Sumach is a greenish yellow tanning material consisting of the young twigs and leaves of a Sicilian shrub very finely ground. This shrub grows well under the conditions of the dry Mediterranean summer, and it has now spread into Tunis and Algeria, as well as to 
South Africa. A very similar plant, lentisk, of somewhat inferior tanning value, is grown in Cyprus. It is often used to adulterate the more valuable and expensive sumach. Genuine sumach produces soft light-coloured leathers, and is much used in the tanning of goat and sheep-skins for special purposes, especially when bright colours have to be afterwards used in dyeing the leathers. It is also used as a mordant in cotton and wool dyeing. There seems no reason why sumach should not be freely grown in Australia and New Zealand, where it could be used for tanning some of the lamb and sheep skins so plentiful in those countries.

\section{VEGETABLE OILS AND FATS}

A large number of plants yield sufficient oil to pay for extracting. In many cases the oil is extracted from the fruit or seed, but in some cases from the root. Oilyielding plants are found in both tropical and temperate regions, but far more is obtained from various plants growing in the hot lands. Oils and fats are extracted by pressure or by solvents from a great number of plants, some of which enter largely into export trade, while many have a more local and limited use. The most important and widely-used are the following: olive oil, rape oil, ground-nut oil, cotton-seed oil, sesame oil, beech-nut oil, linseed oil, hempseed oil, castor oil, palm oil, cocoa (cacao) butter, shea butter, coco-nut oil, palm-kernel oil.

Olive Oil.-The distribution of the olive has already been discussed. The oil is expressed from the pericarp of the fruit, and the best kinds are used chiefly as a table-oil for cooking and preserving. The oil from Lucca in Western Italy is especially preferred for that purpose. Inferior kinds are used in soap-making. It is now largely adulterated with ground-nut oil and 
cotton-seed oil.. Italy exported $2 \frac{1}{4}$ million pounds worth of olive oil in IgII.

Rape Oil.-This is made from the seeds of different species of brassica, which are widely cultivated in Central Europe and in Northern India. The seeds of Brassica rapa yield the variety known as colza oil. Both kinds are used for lighting and lubrication.

Ground-Nut Oil is obtained from the nuts of arachis, the ground-nut plant. The pods bury themselves in the ground to ripen, hence the name ground-nuts. It is a native of Western Africa or the West Indies, and is grown in both regions. British West Africa exports large quantities, chiefly to Marseilles, where the oil is used instead of the more expensive olive oil. The plant has been cultivated in India in recent years, and large quantities of the oil are now exported from there ; over 30,000 tons of ground-nuts were produced in India in rar3.

Cotton-Seed Oil.-The distribution of the cottonplant has been discussed already. The oil is expressed from the kernels of the seeds after removal from the "shells." The kernels are crushed between rollers to form cotton-seed meal. This is then placed in woollen bags, and submitted to hydraulic pressure at a temperature of about $100^{\circ} \mathrm{C}$. When the oil has been extracted from the seeds ${ }^{1}$ there is left in the press a residue which is known as oil-cake, and which forms an excellent cattle food. The oil is chiefly used for lubricating purposes and for soap-making, but considerable quantities of the refined oil are used to adulterate olive oil.

Sesame Oil or Gingelly Oil.-The seeds of a plant Sesamum indicum yield more than half their weight of oil. It is cultivated in Egypt, Asia Minor, and India

${ }^{1}$ It is the same with many other oil-seeds. 
most largely, though it thrives in all the warmer climates. The oil is used for lighting, and as a table oil in the East. India had 5,000,000 acres under sesamum in I9I3 and produced 470,000 cwt. of sesame-oil seeds.

Beech-Nut 0il.-This is obtained from the fruit of the beech in the south of France, in the southern Carpathians, and northern Balkan regions, where the beech abounds. It is used for soap-making, chiefly in France.

Linseed Oil.-This is one of the most important of the oils. It is extracted from the crushed seeds of the flax plant, either by pressure while hot, or by such solvents as carbon-bisulphide or petroleum. The crushed meal, after extraction of the oil, is an important cattle food. Linseed oil is used most largely in the preparation of paints and varnishes, and in making oilcloth and linoleum. It is the best known of the drying oils; on exposure to the air it absorbs oxygen and becomes hard and dry. It is also used for soap-making. As was pointed out on page 292, flax grown in hot countries yields more oil than that grown in colder countries. India produced 530,000 cwt. of linseed in I913. Argentina now exports large quantities of linseed, and a further supply is exported from Russia.

Hemp-Seed Oil is used for similar purposes, and is frequently used as an adulterant of linseed oil.

Castor Oil.-This oil is obtained from the seeds of the castor-oil plant, Ricinus communis, which is probably a native of tropical Africa. It is now grown in many tropical lands, India and Southern China being probably the largest producers. The British supplies of the oil come mostly from Bengal. It is used in medicine and for soap-making in western lands. In China and India it is a table oil.

All the oils mentioned above are liquid at ordinary temperatures. There are, however, many vegetable 
oils which are solid at the same temperatures; these are generally known as vegetable fats or vegetable butters. There is, of course, no real difference; it is simply that the melting-points of the solid group are higher than those of the liquid oils. The vegetable oils or fats now to be discussed are solid at ordinary temperatures.

Palm 0il.-This oil is obtained from the fleshy outer covering of the fruit of several species of African palm trees. The best known is the Guinea oil tree. The oil as it comes into commerce varies in consistency from soft butter to rather hard tallow. It is used in soap and candle-making, in the tin-plate trade, and as a cart and carriage grease or lubricant. West Africa is responsible for the largest supplies of this oil.

Cocoa (cacao) Butter.-This is obtained from the seeds of the cocoa plant, Theobroma cacao. It is a whitish or a yellowish semi-solid fat which is used in the manufacture of superior soaps. The distribution of the cocoa plant has been mentioned in Chapter XIV.

Shea-Butter.-This is a yellowish fat or oil which is obtained from the seeds of several species of Bassia, a genus of tropical trees. The chief regions are India and Central Africa. The "shea-tree," or Bassia Parkii (from Mungo Park, the celebrated traveller), is a very important tree in the commerce of tropical Africa.

Coco-Nut Oil. - This is obtained from the coco-nut, the fruit of a species of palm which, as pointed out already, is grown widely in the tropics. The oil is got from the kernels, which are often dried and exported to the industrial countries under the name of copra. This vegetable fat is widely used in soap-making, margarine making, and for other purposes. It is exported from Madras and Ceylon in large quantities.

Palm-Kernel Oil. - This oil is extracted from the 
kernels of palm-fruits, chiefly by the use of carbonbisulphide. It is quite different from the oil obtained from the outer covering of the fruit. It is very similar to coco-nut oil in appearance, and is used for the same purpose, viz., soap-manufacture. The kernels are chiefly exported from West Africa.

GUMS, WAXES, ETC.

Resin is the general name for a number of substances which exude from the stems or branches of certain trees, and which have the same general properties. The best-known comes from the southern United States, where it is obtained from the "Southern Pine." It is the residue after the distillation of the oil of turpentine from the crude turpentine obtained from those trees. The United States is the chief exporter of both oil of turpentine and resin. Resin is used in soap-making, in the preparation of varnishes, and in paper manufacture.

Kauri Gum is a resin obtained from a pine in New Zealand, or from deposits found in those parts of North Island which were formerly covered with forests of that pine.

Many gums or resins are obtained from trees which grow in and near the warm temperate and tropical deserts. Frankincense, myrrh, gum benzoin, gum arabic, gum acacia, gum tragacanth, and gum tragasol are among the best known.

Camphor.-This is a crystalline substance obtained from a tree growing in the monsoon lands of southeastern Asia; it is a native of China, Formosa, and Japan. Camphor is found in all parts of the plant, but the greater part is extracted from the wood of the stem. Borneo Camphor is obtained from the stem of a different tree which occurs in Borneo. 
Eucalyptus Oil and Gum.-These are obtained from trees which are natives of Australia and in the southeastern parts of the Malay Archipelago. The oil exists chiefly in the leaves; the gum or resin in the bark. Eucalyptus oil is now widely used in medicine. Eucalyptus trees have been planted in Corsica, Sardinia, and the marshy lowlands near Rome, as it is believed they will counteract the malarial effects of the marshes. It will be noticed that this is another example of the transference of trees from one region with a Mediterranean climate to another where the conditions are similar.

Rubber.-This is the solidified juice obtained from a number of tropical trees. All the trees flourish in the hot, wet forests. The trees are tapped and the juice which runs out is allowed to stand. The separated creamy-like substance is then heated with a small percentage of sulphur. This "vulcanised" rubber is then available for a variety of purposes in the arts and manufactures and in every-day life. Nearly half the world's supply comes from Brazil, the valley of the Amazon yielding the bulk of this. Para, at the mouth of the great river, is the greatest place of export in the world. Bolivia, Ecuador, Venezuela also yield considerable quantities. Central America, the hotter parts of the West Indies, and the low coastal plain of Mexico are other American localities. Tropical West Africa comes next to Brazil and yields about one-fifth of the world's output. In the valleys of the Niger and the Congo the collection of "wild " rubber has increased rapidly in recent years. Other regions are Assam, Borneo, Java, and other parts of the Eastern Archipelago. The world's output in rgra was about 90,000 tons, of which roughly 40,000 tons came from Brazil. The industrial countries using most rubber are the 
United States, the British Isles, and Germany in the order named.

Gutta Percha is a closely allied substance, used for the same purposes, and prepared in the same way. It is obtained from trees which are native in the Malay Peninsula, Java, and Sumatra. The bulk of it is exported from Singapore to the industrial countries named above.

TIMBER

An enormous international trade is now done in timber, though it forms such a bulky commodity, and is consequently somewhat expensive to carry. The different vegetation regions of the world yield their different timbers, those of the tropics being of different nature and being used for quite different purposes from those of colder regions.

Timber from Tropical Lands.-Several hard woods, much in demand for furniture, are found in the hot, wet forests, and in the lighter summer rain and monsoon forests. Mahogany belongs to tropical America, the chief supplies coming from Honduras, the lowlands of Mexico, Cuba, Hayti, and Jamaica. Ebony wood is a hard, black wood obtained from trees grown chiefly in the forests of India. Rosewood comes from trees found in the forests of Brazil. Teak is a most valuable timber grown in India, Burma, and Java. Rangoon is a great place of export. Teak is a very hard wood, and it shows little tendency to "rust" even when continually exposed to moisture.

Timber from Warm Temperate Lands.-Several important timber trees are grown in the warm temperate regions, both those of the western or Mediterranean type and those of the eastern or dry winter type. In the Mediterranean region itself the walnut is an important tree, especially in the Balkan countries. Box- 
wood is another important timber tree. The cork oak is grown in Spain, Corsica, and on the western slopes of the Atlas. The famous Cedars of Lebanon are, of course, in lands of Mediterranean type, but they do not contribute to the timber of commerce. Both white cedar and red cedar are found in warm temperate lands, and in those which are transitional from warm temperate to tropical, such as the West Indies and Central America. The famous "Gulf Pine" of the United States is exported in large quantities from Louisiana, Florida, and South Carolina. The redwood and Douglas pines of California are also important timber trees. From Australia there are obtained durable timbers such as that from the Jarrah, a gigantic species of Eucalyptus, and the Karri, another species of the same genus. Both furnish very hard timbers which are widely used; they will even stand immersion in salt water, and are used for the building of piers, etc. The Kauri pine of New Zealand is another important tree from these warm temperate lands.

Cool Temperate and Transitional Lands.-There are two types of forests, which furnish hard woods and soft woods respectively. The hard woods come from the deciduous forests. The oak, varieties of the elm, beech, and ash are among the most useful timber trees of the deciduous forests. The more northern coniferous forests have their counterpart in the hilly parts of the warm temperate lands. From these come immense supplies of soft woods. The white pine, hemlock, spruce, birch, and Scotch Pine are among the famous timber trees of the cool temperate lands. A vast lumbering industry is carried on in the cool marginal lands. Scandinavia, Russia, Eastern Canada, and Western Canada supply the largest quantities of timber, together with the interior forests of Central Europe 
(more especially the Carpathians), and the slopes of the Rocky Mountains. The timber of the western marginal lands of south-western South America has not yet reached the European market in such large quantities. as that from Scandinavia, Russia, and Eastern Canada. The forests of Amuria and Kamchatka are still practically untouched.

Materials for Paper-making. - The immense quantities of paper needed in modern life demand a correspondingly large output of vegetable fibres from which the paper is made. The chief materials are timber from cool temperate lands and grasses from warm temperate lands. The woody fibre of spruce and pines is ground down to a pulp (wood pulp) and exported in the form of pressed sheets or boards; vast quantities of timber are indirectly used in this way. Esparto grass from Spain, the similar Alfa grass of Northern Africa, and the Delta grass from the plains of Rumania are all used in considerable quantities. In China and Japan the inner bark of the mulberry tree is used, and the paper made is very strong.

\section{BIBLIOGRAPHY}

(I) Introduction to Plant Geography. M. E. HARDY. Clarendon Press.

(2) Plant Geography. A. F. W. Schimper. Clarendon Press.

(3) Plant Ecology. E. Warming. Clarendon Press.

(4) Types of British Vegetation. A. G. Tansley. Cambridge University Press.

(5) Introduction to the Study of Agricultural Economics. H. C. TAYLOR. Macmillan \& Co.

(6) Tillers of the Ground. M. I. Newbigin. Macmillan $\&$ Co.

See also the works on Commercial Geography mentioned at end of Chapter XVIII. 


\section{CHAPTER XVI}

\section{GEOGRAPHICAL DISTRIBUTION OF ANIMALS}

Animals are directly or indirectly dependent on vegetation, and the characters of the animals inhabiting a region are adaptations to the physical features and climate and the kind of plant-life found there. There are, broadly speaking, four great regional types of land surface in this connection-forests, grasslands, deserts, and mountains, and in a brief survey of the "animal geography" of the world these simple divisions may be taken as the basis of the study.

The present distribution of animals is not entirely accounted for by present environment; the migration of animals in the past, and consequently the distribution of land and sea in past geological ages, have exercised a directing influence on present faunas. Thus Australasia contained very few of the higher orders of mammals when it first became known to the western world; probably the Australasian lands were separated from the rest of the land in the Mesozoic era, and very few migrations of the later-developed animals have reached it since that time. South America contains a peculiar animal assemblage which inhabits its very varied lands, from the hot, wet selvas to the southern pampas of Argentina. The development of animal life has long proceeded on lines of its own in that continent, with probably few migrations from other continents.

The influence of man has already made itself very 
widely felt ; the herds of horses on the American grassy plains are the descendants of those introduced by the early explorers ; on the other hand, man has very nearly exterminated the magnificent herds of bison which inhabited the prairies of North America only fifty years ago. Man has introduced many animals which have become exceedingly plentiful; the horses of South America, the rabbit of Australia, the wild pig of New Zealand, are conspicuous examples.

The full study of the geographical distribution of animals, with the explanations drawn from the evolution of the present continents, including the adaptation of animals to their environment, and the study of the evolution and development of species, belong to Natural History, and especially to Zoology. The chief animals of the different regional types will be briefly studied here, more especially those which are useful to man.

Animals of the Tropical Forest.-The animals which inhabit the equatorial forests show in a remarkable degree adaptation to the special conditions. These special conditions include abundant food all the year round, with fruits ripening at all times of the year; no special seasonal differences of temperature are experienced. The luxuriant undergrowth of the hot, wet forests is another of the special conditions. There are consequently many animals which never descend to the ground, and they are specially adapted to their arboreal life. The somewhat more open forests of the hot monsoon regions and of the tropical summer rains have more large animals which are ground dwellers, and they have also many "flying" animals. Among the larger carnivorous animals are the tiger, the leopard, and the South American jaguar. South America has many species of sloths and tapirs. The tapirs of the Malay Archipelago are forest-dwellers. Elephants are found in 
the forests of Africa and the forests of the monsoon region of Asia. The rhinoceros and hippopotamus are other mammals from the very extensive list of tropical faunas. Lastly, the crocodiles and their allies may be mentioned, with the pythons and boas, and the great anaconda of the Amazonian forests.

The anthropoid or man-like apes are all dwellers in the tropical forests. There are at least four species: the gorilla in the forests of West Africa, the chimpanzee in those of West and Central Africa, the ourang-outang of Borneo and the adjacent islands, and the gibbons of the mainland of South-East Asia. They live chiefly on fruits, eggs, and young birds.

It will be seen that the number of useful animals is not great; the elephants, of course, must be reckoned, but they are savana animals as well as inhabitants of the dense jungle.

Birds are very abundant and exceedingly varied. The gorgeous birds of paradise inhabit the forests of New Guinea and neighbouring lands; the bright-coloured macaws live in the South American forests; the crested cockatoos inhabit the north Australian tropical forests; and most of the parrots are tropical. The brilliantly coloured humming-birds of South America are represented in all museum collections.

Animals of the Tropical Savana and adjacent Deserts. -The conditions are clearly quite different when we pass to those tropical regions which have a low rainfall. The savana passes into the caatinga and then into the desert usually so gradually that in this connection they may be grouped together. It is well to remember that the period of greatest growth follows or accompanies the rainy season (which may be short and irregular). In the long dry season plant-growth is almost suspended. Hence the animals are such as can move 
freely, are often fleet of foot, and they are frequently migratory.

The lion is an animal of this region in Africa and Asia, its uniform colouring adapting it to parched and brown savana grasses and to desert rocks and sands. The hyæna is a smaller carnivore of the savana. The Cape hunting dog is a hyæna-like animal which hunts in packs, and preys upon the wild hoofed-animals, and the flocks and herds kept by man.

The ungulates or hoofed animals are the most striking of the animals of the savana, especially of the African savana. The antelopes are very varied and exceedingly numerous in individuals. The giraffe is a beautiful example of adaptation; its long neck and fore limbs are obviously adapted to its habit of browsing upon the leaves of acacias and other savana trees. It can only drink with difficulty and it can apparently go for months without drinking. It is capable of very great speed to enable it to escape the attacks of its enemies, the carnivores. The wild ass and the zebra occur mainly in the region transitional from the tropical to the warm temperate. The camel is the highly specialised desert animal and is also transitional in type.

Among the animals of the savana, the running birds show special adaptations to the conditions. The ostrich is the best example, found in Africa, Arabia, and Mesopotamia. Its long legs and neck enable it to see great distances; the long legs, and the reduction of the number of toes to two, enable it to run with great speed. Like the giraffe it can endure for a long time without water. The emu of Australasia is also a savana bird, feeding on the grass of the plains.

Animals of Warm Temperate Regions.-These regions are transitional between the tropical and the cold temperate and have no highly specialised assemblage of 


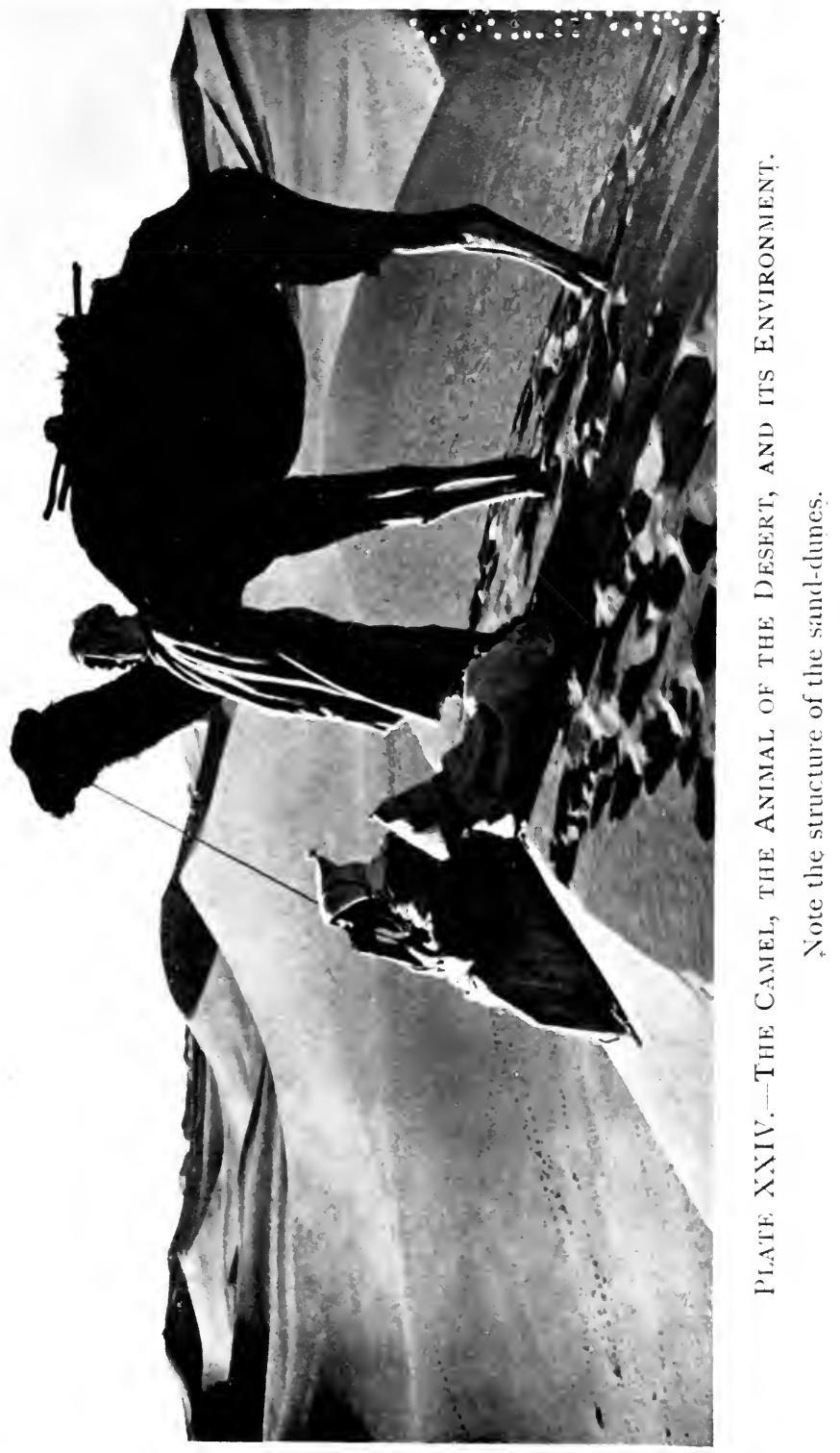




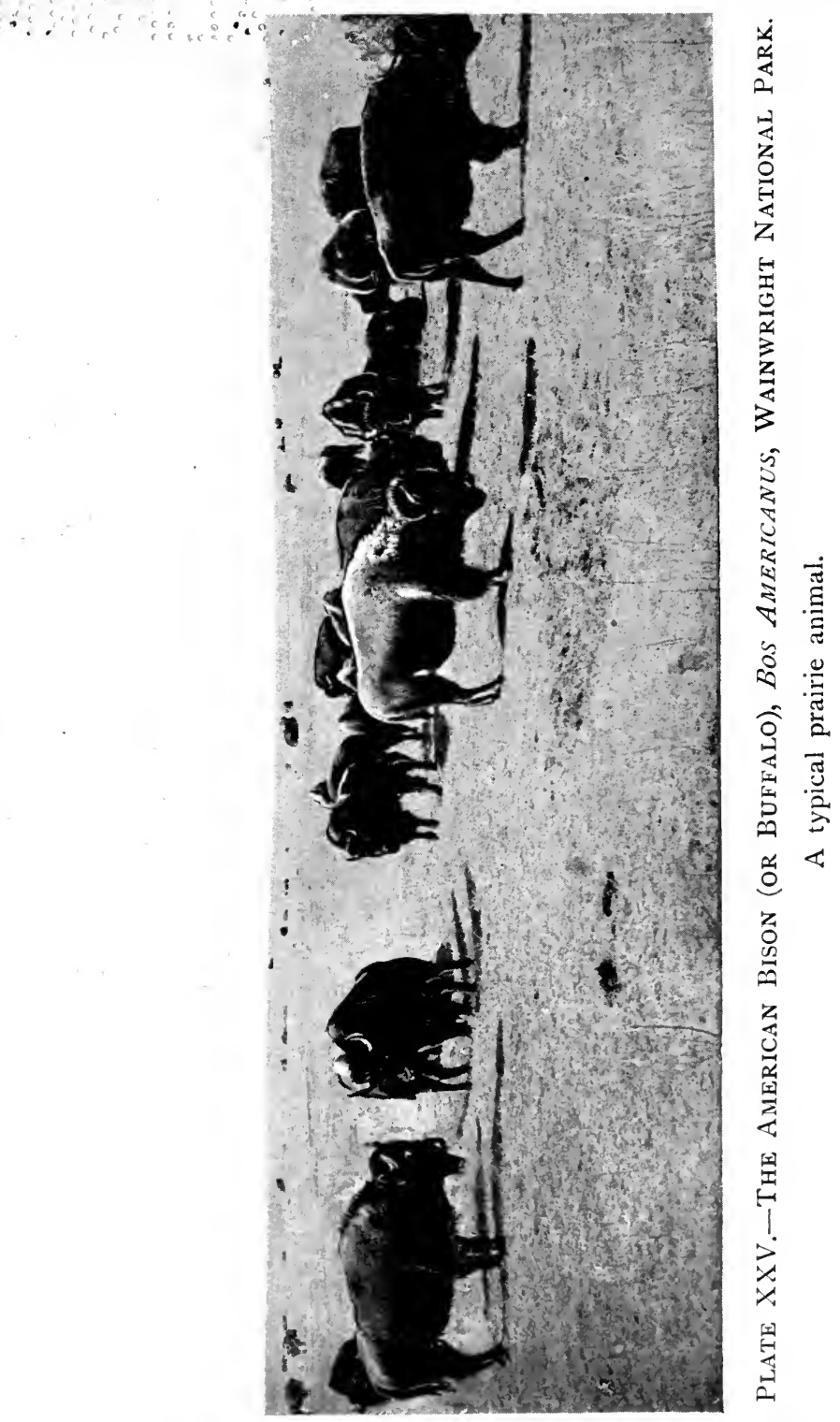


animals. It happens that many of the lands in this climatic zone are either mountainous or plateau, and there is consequently a considerable development of mountain faunas of different types. So far as animals of economic importance are concerned it is especially the zone of sheep and goats rather than of cattle, especially in the Western Marginal or Mediterranean lands. Sheep and goats can browse on the dried and sparse grass, or on the bushes which can resist the dry summer, but cattle fare much worse under these conditions. The eastern marginal lands have more cattle, either the different breeds of the common or domestic ox, or the eastern zebus or buffaloes which are characteristic of the tropical as well as the warm temperate zones. There are several species of goats found in the warm temperate zone, more especially in the drier Mediterranean lands, from which they have been acclimatised in similar regions in Africa and America. For example, the mohair goat of Asia Minor does well on the plateaux of South Africa, just as the Spanish merino sheep thrives well in Australia. The horse, the ass, and the wild ass are other animals which are either native or do well in the warm temperate lands, the wild ass being a characteristic animal of the drier Old World lands of this type. This zone shares with the drier tropical lands the camel and dromedary as beasts of burden.

Animals of the Cool Temperate Zone.-The three chief vegetative types may be considered: The taiga, the deciduous forest, and the steppe or prairie, the latter two overlapping into the warm temperate zone. The animals of the taiga or coniferous forest may be dealt with first. There are two broad groups of such animals: those which are structurally adapted for forest life, such as the squirrel and the lynx; and those which roam over the prairie but visit the forest for 
shelter or food; of these, the fox and the wolf are examples.

The important animals of the taiga belong either to the ungulates or hoofed animals, the rodents or gnawers, or the carnivores. The ungulates include the wild boar and many varieties of deer. The rodents include squirrels, the beaver, rabbits, and the Canadian porcupine. The carnivores are chiefly bears, lynxes, the wild cat, and members of the weasel family.

The deciduous forest is the home of similar animals to those of the coniferous forest; squirrels, beavers, wild boars, and bears making their homes there. The wild boar of the deciduous forests of Europe still flourishes.

The steppe or prairie is inhabited by special types of animals adapted to the physical conditions. The climate is continental in character, that is, with wide ranges of temperature and a low rainfall, and the great plains are often swept by violent storms. The rains generally fall in spring and summer and there is a wonderful growth of the prairie plants at this time. If the rain fails there is corresponding scarcity. There may thus be frequent alternations of plenty and famine, and the animals are migratory and social in consequence. The prairie animals must also be swift of foot so as to migrate quickly from one region of plenty to another.

Antelopes and gazelles are among the most numerous of the steppe animals. In the steppes of western Asia the Taiga antelope occurs in thousands; and $P$. Kropotkin quotes countless herds of antelopes in the eastern higher steppes. Horses are typical steppe animals, no less than three species being native to the Asiatic steppes. The prairie and steppe extend into the warm temperate zone, as has been already pointed out, and the horse as well as the camel overlap considerably the two sub-zones. The great herds of horses on the 
pampas of South America and the plains of North America are the descendants of horses introduced by the earlier conquerors of the continent. The bison takes the place in the New World of the antelope or horse of the Old World, and was originally exceedingly plentiful. It has been calculated that there were between seven and eight millions in two vast herds, a northern and southern, in the great plains in $187 \mathrm{I}$. Now there are a few hundreds, specially protected, in the natural parks.

The sheep is naturally more of a mountain animal, but it thrives well on the grassy prairies, and the vast flocks of Argentina and of the Darling Downs of Australia show how well it is adapted to the plains.

The plains mentioned are in the warm temperate zone, but the sheep ranges into cool temperate plains in Siberia and Canada, and to the drier and less fertile plains of Europe.

The wolf is almost ubiquitous in temperate regions, but it is more especially a steppe animal. As is well known, it hunts in packs, preying upon the numerous ungulates and rodents of the great plains.

Animals especially adapted to Life on the Mountains. -Mountains usually show three fairly well-defined zones of altitude as regards their vegetation. The lowest is the forest zone, the nature of which depends upon the latitude of the mountains. In the tropics the lowest parts are clothed with equatorial forest ; in the temperate lands the lower slopes may be rich in deciduous forests. In any case conifers predominate in the highest forest zone. Above the belt of conifers comes a treeless zone, with practically the character of a steppe ; and last of all, if the mountains are sufficiently high, comes the Alpine zone, with tundra vegetation. There are some interesting modifications in the nature of 
these vegetation zones, which influence the special fauna. For example, in tropical Africa the steppe zone is extremely dry, and becomes practically a semidesert belt. In plateau regions the steppe conditions may extend over a very wide area, as in the plateaux of Asia, and the lesser Meseta of Spain for example. If the plateaux are very high then tundra conditions hold, as in part of the vast elevated plateau of Tibet.

The special features of the fauna of mountains are the paucity of carnivores and the richness in ungulates. Probably the two are correlated. The ungulates are as a rule obviously well adapted to mountain conditions ; they have great agility, are small footed, and have special protections against cold. Sheep and goats are perhaps the most typical mountain forms, just as antelopes are typical of the steppe and savana. Goats can thrive in drier and more barren regions than sheep, as they do not hesitate to eat even the spiny or hardleaved plants of the high plains. They can also climb and leap among the rocks with great ease.

There are several "wild sheep" among the mountain regions of the northern continents. The Bighorn of the Rocky Mountains and the Pacific coast mountains ranges from northern Mexico to Alaska; its vertical range is so great that it is known on the lower walls of the Grand Cañon of Colorado, and in the Sierra Nevada and Cascade Mountains it lives at elevations of over I0,000 feet. Its name indicates the unusual size of its horns, which are used in fighting. It is a splendid mountaineer, and can leap from crag to crag with remarkable agility. Its feet have a rubber-like pad beneath the sharp pointed hoofs to enable it to get foothold even on smoothly glaciated rock-surfaces.

There is a very closely related species in Alaska, the Alaskan wild sheep, and both are so similar in 
appearance and build to the wild sheep of Kamchatka as to suggest a former land bridge connecting Asia and America across what is now Bering Strait. Of course there are many other evidences of the former land connection of the two continents.

The Mouflon of the mountains of Corsica and Sardinia, the Barbary sheep of the Atlas Mountains, the Argali and the Urial of the mountains of Central Asia are other species of wild sheep all more or less adapted to mountain life.

The goats are essentially mountain and plateau animals, with a distribution very similar to that of the wild sheep, except that there is no true goat in America. The Mazania or mountain-goat of the northern half of the western mountains is really an antelope which in becoming adapted to life on the high mountains has developed some goat-like characters. Ten or more species of goats live on the Old World mountains, mostly in Asia and Europe, though an ibex is native to the Abyssinian Mountains and the Arabian wild goat is found in Upper Egypt. Distinctive species inhabit the different mountain ranges of Eurasia, the Spanish wild goat in the Sierra Nevada and Pyrenees, the Alpine ibex in the Alps, the Markhor in the Himalaya, etc.

Among the mountain fauna of South America are the very interesting specialised camels. There is no hump, but the stomach has a cellular apparatus for the storage of water, and the animals can live for a long time without drinking; the upper lip and the nostrils are similar in structure to those of the Old World camels, but the feet are modified to suit mountain conditions. There has been some dispute about the number of species. Four distinct names are used, two for wild camels, and two for those which have been domesticated. The wild species are the Guanaco and the Vicuna. The 
former ranges from the highlands of Peru to the plains of Patagonia and the wooded islands of Tierra del Fuego. The vicuna inhabits the steppe zone of the mountain ranges near the verge of perpetual snow. The Llama and Alpaca are domesticated, and the latter is kept in large flocks in Peru and Bolivia for the sake of its lustrous silky wool.

Animals of the Tundra. - The climatic conditions of the tundra may be briefly recapitulated. The average temperature of July does not anywhere exceed $50^{\circ}$, and is generally much lower than this. There is little rainfall or snowfall; always less than ro inches per annum, and generaily much less. The winters may have little or no snow. The sub-soil is permanently frozen, and there is no ground water. The winter is very long, the summer is short, and though there is virtually continuous daylight, the rays of the sun fall at a low angle. The plant-life is determined by these conditions. The most important consideration is the abundance of lichens and mosses which survive the winter and provide food for herbivorous animals all the year round. There are dwarf alders and willows, and some berrybearing shrubs, and these provide food in the short summer. Even with these there is very little food on the land, and some of the tundra animals derive their food from the sea, and thus inhabit the marginal lands only.

The animals which will be considered here are the reindeer, the musk ox, the Arctic fox, the wolf, and the polar bear. The reindeer is widely spread throughout the tundra region. As is well known, its food consists largely of the lichen, popularly called reindeer moss. On the Continent it migrates towards the northern edge of the taigga in winter, but this is plainly impossible for the large numbers which inhabit the Arctic islands. The American tundra has a distinct species, the barren- 


$$
\begin{aligned}
& \vdots \vdots \vdots \because \quad \because \because ;
\end{aligned}
$$

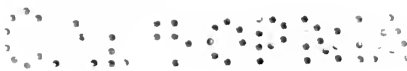




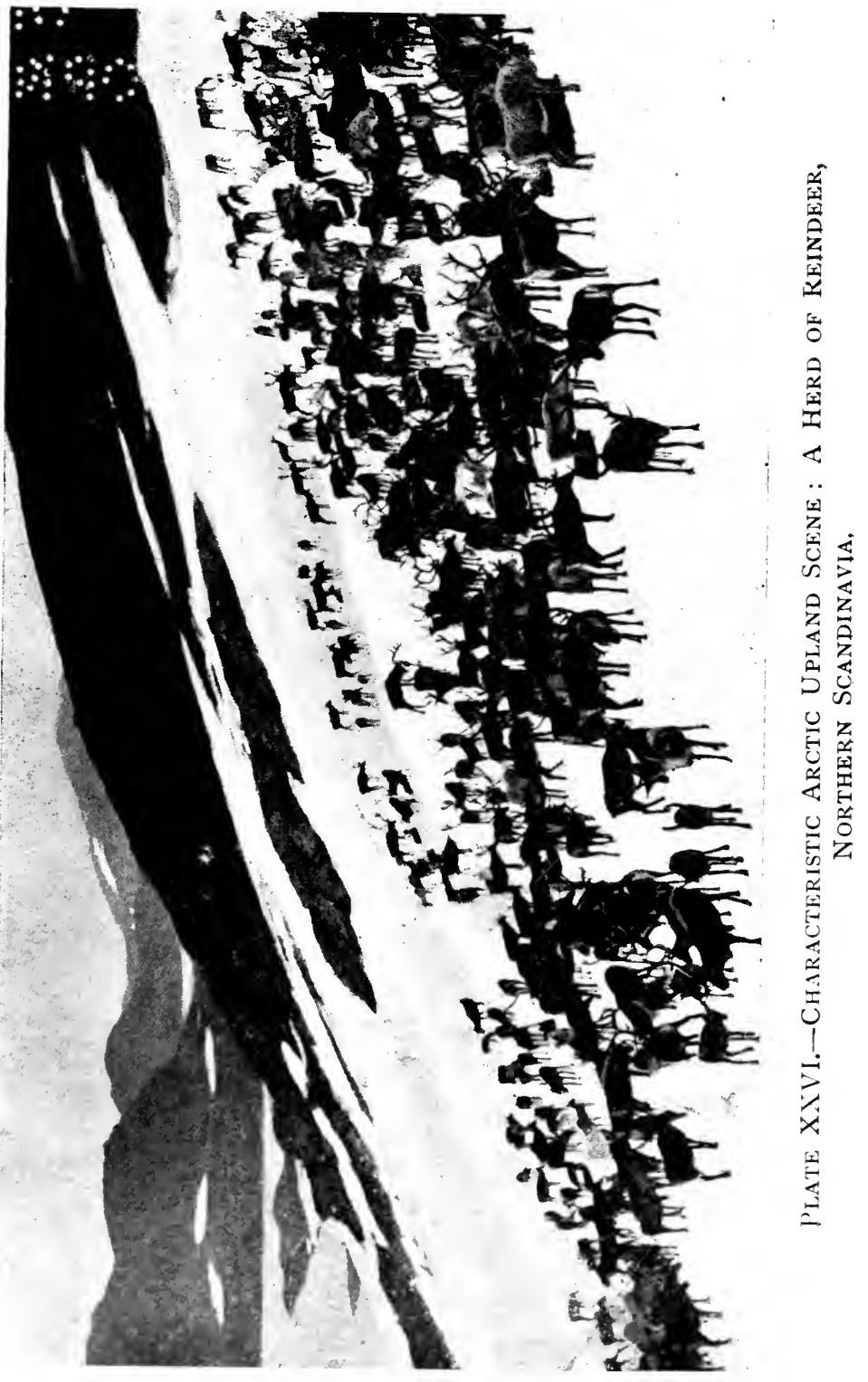


ground caribou, which occurs in large herds on the treeless plains to the west of Hudson Bay. It migrates southward to the edge of the forest. There is another allied species in America which has taken to the forest, and is hence known as the woodland caribou. The true reindeer of the Old World has been introduced into Alaska by the United States Government, and under the care of herds-men from Lapland the animals are doing well.

The musk ox is another ungulate of the tundra, and of the northern edge of the taigga, but it is limited to the New World. Its distribution is not known with certainty, but it seems to be absent from Alaska, and plentiful in northern Greenland. It combines some of the characters of sheep, goats, and the ox, and is peculiarly adapted to the extreme cold. It is probably the hardiest of all herbivores.

The presence of these large herbivores attracts the carnivores, which are, however, less highly specialised and may be regarded more as intruders from other regions. The wolf occurs in both Arctic Eurasia and Arctic America, both in the tundra lands and in the Arctic higher-lands. The Arctic fox is more thoroughly Arctic, and is widely distributed in both the Old and the New World.

The polar bear haunts the margin of the sea. Its large size, and its white or yellowish white colour, distinguish it sharply from other bears. It lives on the seal and walrus, and haunts the drift and floe ice in search of its prey. It seldom penetrates far inland.

\section{Animals from an Economic Point of View}

A comparatively small number of animals are very important economically, and this aspect of the subject may be briefly treated here. The chief animals whose 
products enter into commerce are cattle (in the wide sense), sheep, goats, camels, the reindeer, and the horse.

Cattle are associated with civilised man almost everywhere, but there are interesting differences and limitations. The Chinese keep few cattle except for draught purposes, as with their teeming population the land is considered too valuable for grazing. The number of cattle in the Mediterranean countries is in sharp contrast with the number in countries like Denmark. The following table, giving the number of sheep, cattle, and goats in four European countries, is instructive :

\begin{tabular}{|c|c|c|c|}
\hline & Cattile. & Sheep. & Gonts. \\
\hline $\begin{array}{l}\text { Spain, I95,000 } \\
\text { sq. miles. }\end{array}$ & $\begin{array}{c}2,500,000 \\
\text { (12 } \cdot 8 \text { per sq. } \\
\text { mile.) }\end{array}$ & $\begin{array}{l}16,000, \infty 00 \\
\text { ( } 82 \text { per sq. } \\
\text { mile.) }\end{array}$ & $\begin{array}{c}3,100,000 \\
\text { ( } 55^{\circ} 9 \text { per sq. } \\
\text { mile.) }\end{array}$ \\
\hline $\begin{array}{l}\text { Greece, } 44,000 \\
\text { sq. miles. }\end{array}$ & $\begin{array}{c}500,000 \\
\text { (I I } 3 \text { per sq. } \\
\text { mile.) }\end{array}$ & $\begin{array}{l}4,500,000 \\
\text { (102 per sq. } \\
\text { mile.) }\end{array}$ & $\begin{array}{c}3,000,000 \\
(68 \cdot 2 \text { per sq. } \\
\text { mile. })\end{array}$ \\
\hline $\begin{array}{l}\text { Denmark, I } 5,000 \\
\text { sq. miles. }\end{array}$ & $\begin{array}{c}2,250,000 \\
\text { (I } 50 \text { per sq. } \\
\text { mile.) }\end{array}$ & $\begin{array}{c}730,000 \\
\text { (48.6 per sq. } \\
\text { mile.) }\end{array}$ & $\begin{array}{l}\text { Goats not suffi } \\
\text { ciently im } \\
\text { portant to be } \\
\text { enumerated. }\end{array}$ \\
\hline $\begin{array}{l}\text { United Kingdom, } \\
\text { I } 2 \text { I, }, 00 \text { sq. } \\
\text { miles. }\end{array}$ & $\begin{array}{l}\text { I2,000,000 } \\
\left(99^{\circ} 2 \text { per sq. }\right. \\
\text { mile.) }\end{array}$ & $\begin{array}{c}29,000,000 \\
\left(239^{\circ} 6 \text { per sq. }\right. \\
\text { mile. })\end{array}$ & $\begin{array}{l}\text { Goats not enum } \\
\text { erated. }\end{array}$ \\
\hline
\end{tabular}

The comparison of $I 2 \cdot 8$ and $I I \cdot 3$ cattle per square mile in the Mediterranean countries, with $I_{50}$ and $99^{\circ} 2$ per square mile in the Western Marginal lands, is an illustration of the difference of climatic conditions. Milk, butter, and cheese have not assumed the importance in the Mediterranean lands that they have in north-western Europe.

How widely spread domestic cattle have now become and how well adaptable they have proved to varying 
conditions, may be seen from the fact that they are reared in large quantities under such different conditions as obtain in Denmark and Egypt, the Siberian plains and the plains of Australia. Egyptian butter now competes with Danish butter in the British markets, and both Russia and Australia are now contributors to the British supply. Cattle may be successfully reared on the high African savana, and on the savana of the East Brazilian highlands. The chief cattle-rearing regions of the world are: India, United States and Canada, Russia (European and Asiatic), Argentina, Germany, France, Hungary, the United Kingdom, Denmark, and Southern Sweden. The north-west of India from Cutch through the Punjab to Kashmir is a great cattle region, the animals being used as beasts of burden, and the hides forming one of the staple exports of that part of India. Eleven million pounds' worth of hides and skins were exported from India in I9I2. The great exporters of live cattle and of carcases or prepared meat foods are the United States, Canada, Argentina, and Australia.

The Sheep is the most numerous of the domesticated animals. It thrives under a greater variety of conditions of climate and food-supply, and can be reared in lands which are not suited to cattle. The four products which sheep yields to man are all of great importance, though wool has often been considered as the primary object of sheep-rearing. But in modern times, mutton, tallow, and sheep-skins contribute a very important share to the wealth of sheep-rearing countries.

The effects of selection and of careful crossing of breeds are well seen in the increased yield of excellent mutton and other products from such sheep as those of New Zealand and Australia. The Merino sheep was 
developed in the Mediterranean countries, where the dry climate of the summer was peculiarly suited to it. It was introduced into Australia about the end of the eighteenth century, and in New South Wales and Victoria sheep of the Merino breed produce an excellent wool, unrivalled for softness and lustre, and of long staple. Merino sheep, however, yield indifferent mutton and quite second-rate skins; hence crossing with English breeds has been resorted to, especially in New Zealand. A good wool, with excellent mutton, rich yields of tallow, and some of the finest sheep-skins in the world for the light-leather tanner are now produced from the New Zealand cross-bred sheep. That colony had 2,000,000 cattle and 24,000,000 sheep in I9II, and exported wool to the value of $£ 7,000,000$, and frozen meat to $£ 4,000$, 000 .

The great wool-producing regions of the world are shown in the following table:

Total wool produced by the world in I9I2, $3,000,000,000 \mathrm{lb}$.

Australasia . . 840,000,000, or 28 per cent.

Argentina . . 410,000,000, or 13.7 ",

Russia . . . 380,000,000, or I2.7 ",

United States - 320,000,000, or 10.7 ",

United Kingdom . I45,000,000, or 4.8 ",

Uruguay . . I20,000,000, or $4^{\circ} \mathrm{O}$ ",

South Africa . . II2,000,000, or 3.7 ",

Goats have already been mentioned as being adapted to a drier climate. They can browse where even sheep find it difficult to get sufficient food, and are not even prevented by the resinous coatings of the leaves and the spines of the Mediterranean trees. Generally speaking, the climate of the Mediterranean regions is drier farther east, and the relative importance of the goat increases. From the table on p. 318 it will be 
seen that Spain has five times as many sheep as goats, but Greece has only $I \frac{1}{2}$ times as many ; and it is probable that if statistics were available for Asia Minor the goats would far outnumber the sheep. The plateau steppes of Asia Minor are the native home of the Angora goat, the wool of which, known as mohair, is highly prized for its length, fineness, and silky appearance. Angora province alone is said to have more than a million goats. This is the breed which has been introduced into South Africa, and the mohair of Cape Colony is now a regular and important export, and threatens to compete seriously with that of Asia Minor.

Farther east among the mountains of Armenia and in Persia and Afghanistan the goat is the most important domestic animal, both for its wool and its milk. The skins of Persian goats are highly prized in the leather industry, and some of the best glacé kid is chrome-tanned Persian goat-skin. The Kashmir goat of the upland valleys and enclosed plateaux of the Karakorum and North-West Himalaya is well known, and yields the bulk of the wool from which the famous Kashmir shawls are made. Goat-skins are tanned in India and exported in large quantities. It may be mentioned that both sheep and goats are used to some extent as beasts of burden among the highlands of Central Asia.

The Pig may be briefly mentioned, confining ourselves to the domestic pig, which is probably a descendant of the wild boar of Europe, North Africa, and Central and Southern Asia. Its usefulness to man, and its wide range, need no comment. In China the pig is by far the commonest ungulate reared, and the large black Chinese pig is found everywhere. In Central and South-Eastern Europe it is estimated there are over 30 million pigs. In the woods of Serbia and Bosnia they feed on the acorns 
and beech nuts of the vast forests. In Western and North-Western Germany the pig is of special importance, especially on peasant farms and small holdings. Westphalian hams are well known. Germany had about 22 million pigs on an average from I900-I9I3. In the British Isles, perhaps more especially in Ireland, the fattening of pigs helps in the upkeep of many a small farm. The number of pigs for the five years, I909I9I3, averaged roughly 4,000,000, that of Ireland being a little over a million. (See also the table on p. 3I8, Cattle and Sheep, etc.) On the prairies south of the Great Lakes of North America pigs are fattened on maize, and various products are prepared and exported from Chicago, Cincinnati, and other towns in that region. The United States had, on an average, about $60,000,000$ pigs in the last four years. Pig-rearing has not reached such great importance in Argentina, as the following number of domestic animals in I9II will show : Cattle, 29,000,000 ; horses, 7,000,000; sheep, $67,000,000$; goats, 4,000,000 ; pigs, I,500,000.

The Horse is the most widely used beast of burden in all the countries of Western Europe and in those lands the civilisation of which is derived from Western Europe. Its native home seems to have been the steppes north of Persia and the plateaux of Central Asia; it was probably first made subservient to man there, and its use afterwards spread to the Semitic people of Arabia and Egypt about three thousand years B.c. The wild horses of America, so very numerous on the pampas of the south, are descendants of those introduced by the Spanish and Portuguese. An earlier horse which had inhabited America had become extinct before the discovery of the continent by Europeans.

The Camel is especially the beast of burden of the hot. deserts and the deserts of the warm temperate 
region. There are two species of camels proper in the Old World, the Bactrian camel with two humps, a native of the same region as the horse, and the Arabian camel with one hump. It is this species that is particularly the "ship of the desert." The camel is remarkable not only as a beast of burden, but its milk and flesh are both used. The Arab also weaves much of his clothing and the material for his tents from its hair.

The camels of the New World have already been mentioned (p. 315). The wool of the alpaca was brought into prominence in England by Sir Titus Salt, and the big mills at Saltaire and others in the neighbourhood of Bradford are still connected with the manufacture of alpaca goods.

The Reindeer is to the men of the cold deserts what the camel is to the men of the warm deserts : it is their beast of burden; they use its milk and its flesh for food ; and its hide, its hoofs, and its horns all minister to their varied wants.

\section{BIBLIOGRAPHY}

(I) Animal Geography. M. I. Newbigin. Oxford Press.

(2) A Geographical History of Mammals. R. LYDEKKER. Cambridge University Press.

(3) The Wanderings of A nimals. H. Gadow. Cambridge University Press.

(4) Outlines of Zoology. J. А. Тномson. Y. J. Pentland.

(5) An Elementary Text-Book of Zoology. A. E. SHIPLEY and E. W. MAcBride. Cambridge University Press.

(6) Three kindred volumes by R. LYDEKKER deal respectively with The Sheep and its Cousins, The $O x$ and its Kindred, The Horse and its Relations.

(7) Variations of A nimals and Plants under Domestication. Charles Darwin. Murray.

(8) Geographical and Geological Distribution of Animals. A. HeIlprin. International Scientific Series. Kegan Paul, Trench, \& Co. 


\section{CHAPTER XVII}

\section{MAN ON THE EARTH}

THE antiquity of man is still a matter of considerable difference of opinion. Some authorities hold.that he was in existence during the later Pliocene, and he certainly seems to have been very widespread in the early Pleistocene. His precise origin is still somewhat obscure, though it is pretty certain that he descended from some ape-like ancestor. $\mathrm{He}$ did not descend from any of the four man-like apes in existence to-day, nor probably from any animal quite like them. It is more probable that he and they are descendants of some common ancestor of Miocene times. Again, it is very likely that modern man is only one of several branches from the common ancestry, some proto-men having become extinct during the long perior of evolution.

It would be very interesting if we could trace all the varieties or races of modern men from the ancestors of early Pleistocene time, but that is not yet possible. There is still a great deal of doubt and obscurity about the precise relationship of the men or proto-men of the earliest times. The remains of early man are so fragmentary and have come from such different regions, that it is not only difficult to correlate the deposits in which they occur, but it is difficult to indicate the relationship of the possibly 


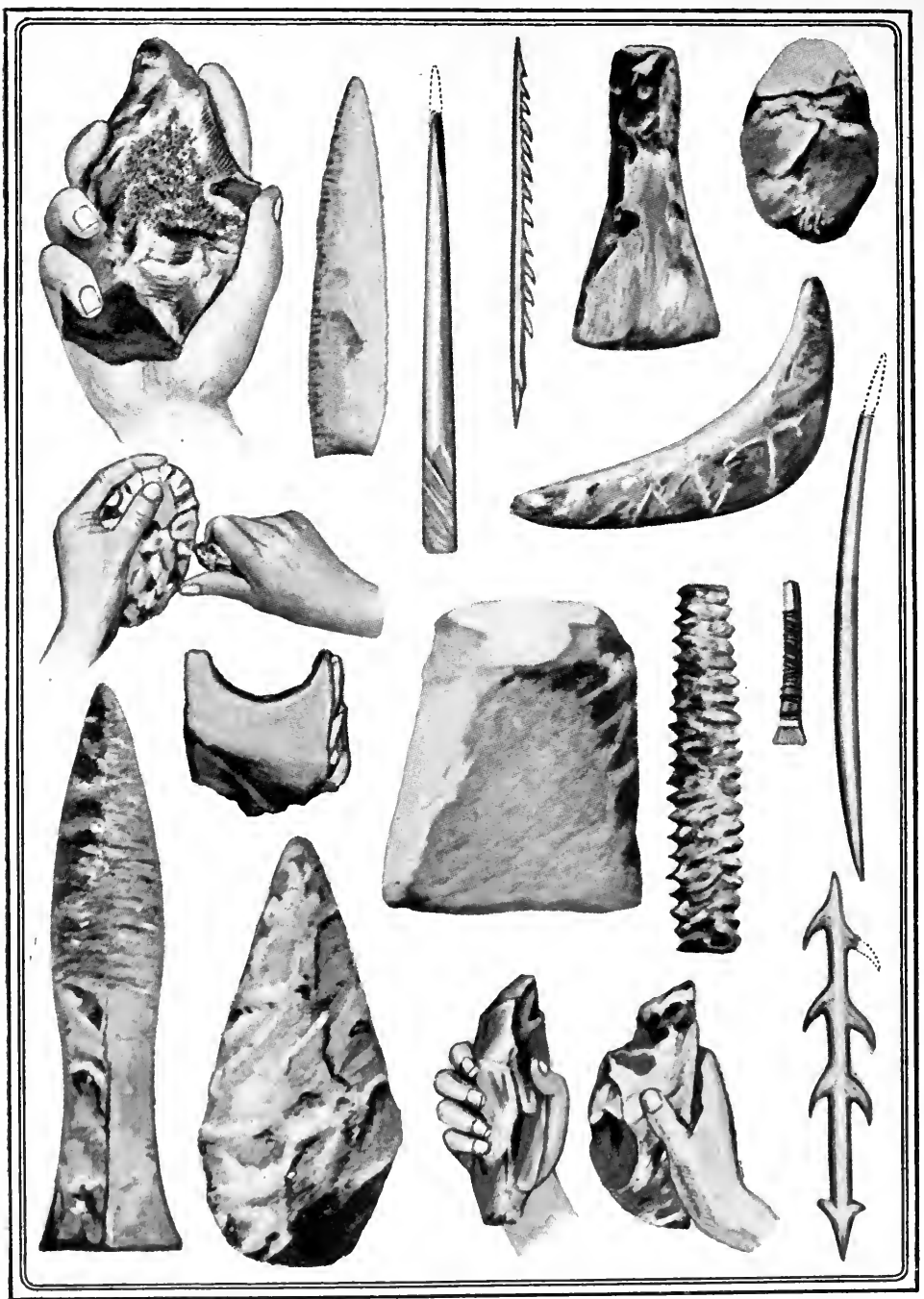

Plate XXVII.-Implements of the Stone Age. From Specimens in the British Museum. 
different types of men. We have, therefore, to take modern man as we find him, and the varieties or races commonly accepted are founded on the characters of man as he is to-day, and have no true evolutionary basis. Our knowledge of early man is chiefly derived $(a)$ from his actual remains; $(b)$ from his weapons and implements ; $(c)$ from a study of rock-shelters, pile-dwellings, mural decorations, " kitchen-middings," and some of his burial places. Amongst the more famous finds of the remains of man, perhaps four stand out as most important. There is a skull in the Provincial Museum at Bonn which was found in a loam in the Neanderthal through which flows the little river Düssel. The Neanderthal skull was studied by Huxley, and has become one of the most famous of the remains of early man. It is distinctly human in character, but of a low grade, and is regarded as being nearer to modern man than to any of the man-like apes. In the loess deposits of the Neckar Valley, east of Heidelberg, a human jaw was found, which is now in the University Museum at Heidelberg. This early Pleistocene relic also indicates a man of a more lowly type than most of the modern savages. In far-away Java a skull and some bones were found in 1892 in strata which were at first thought to be Pliocene in age, but which are now regarded as Pleistocene. This was named Pithecanthropus erectus, that is, ape-like erect man, and certainly indicates a low-grade proto-man, but still more man than ape. A few years ago Mr. Dawson found a skull and part of a jaw in some gravels of the Avon, at Piltdown, in Suffolk, and these have been studied and described by Dr. Smith Woodward and Mr. Dawson. They are regarded as remains of a proto-man or very primitive man, more lowly in type than any savages of to-day. There are many more skulls and odd bones which have 
been found, chiefly in Europe, where of course there has been the most thorough study of likely localities.

In addition to the actual remains, the weapons and implements of men are found almost all over the north temperate and most of the torrid zone. These are made of flint and other hard stone, and were fashioned by early man by knocking one stone with another, and so chipping them until they were of the desired shape. Fine collections may now be seen in most museums. In the earlier stages of man's evolution they were very rudely fashioned, but gradually improvement took place, certainly more quickly in some regions than in others, and in time smooth, well-made weapons became very common. The ruder implements are characteristic of the Palæolithic Period (that is, the older stone age), the more perfectly made ones belong to the Neolithic Period (the newer stone age). There is of course no hard-and-fast line between the two periods, except in so far as students make an arbitrary division in any one district, and the transition from one to the other took place much earlier in some regions than in others. It is not possible to distinguish absolutely the weapons and tools of the one period from those of the other. Palæolithic man had certainly learned to grind his stones, and had anticipated some of the arts of Neolithic times. All this, which would appear to follow from first principles, is fully borne out by extended observation and study. Neolithic man was, of course, a great advance on Palæolithic man in general; he had better weapons and tools, he had acquired some control over fire, and he had begun to bury his dead.

In north-western Europe, Palæolithic man was certainly a contemporary of the glacial period ; he was almost certainly pre-glacial. How far his migrations were influenced by the fluctuations of the ice it is 
difficult to say. The glacialists are still far from agreed as to the number of interglacial periods (of milder conditions) that there may have been. Penck recognises five in the Alps; the late James Geikie claimed as many as eight; some of the Americans believe in three; and Lamplugh and Kendall, well-known English authorities, have argued for an undivided glacial period in Britain at least. It may be remarked that there seems to be no reason why great fluctuations should not have occurred, say, in the Alps, while the ice maintained itself on the whole of Northern Britain. It does not seem necessary to demand the same divisions of the ice age for all parts of the Northern Hemisphere.

Whatever was the precise relation of man to the glacial period, he was a contemporary of the mammoth, the cave bear, the Irish elk, and other extinct animals. He lived in North-West Europe when Britain was still a part of the Continent, and when the Rhine flowed over the North Sea plains. Originating possibly in Indo-Malaysia, he spread to the rest of Asia, with which the land was then connected, and then to Northern Africa.

From there he passed to Europe by the two land connections then existing, Morocco-Spain, and TunisItaly, and established himself throughout the early Europe. After very long years Palæolithic man was replaced by Neolithic man, whether by conquest or by extermination and replacement is not known. After the first settlements of Neolithic man there began the long rise in the knowledge of arts and of phenomena which is the measure of human evolution. The North Temperate zone between the tropic and about latitude $55^{\circ}$ was most favourable, and there he gradually reached his highest physical and mental development. Primitive man of the tropics lagged behind, and the 
peninsulas and islands of the Southern Hemisphere were too restricted to allow of great areas of different rates of development, that is of specialisation.

The Neolithic age gradually passed into the age of metals, first of copper or bronze, then of iron. These persisted for a long time, man slowly developing his powers of expression, first using mere picture-graphs, then conventional signs or ideographs, until phonetic signs led up to alphabets, and the historic age was fully established, which will persist through all future time. With the dawn of history we find the great races of mankind fully established, and it is difficult to establish an unmistakable connection between the various men of Neolithic times and modern races, much more difficult again to work out the relation between Palæolithic men and any races of to-day.

It is supposed that the Tasmanian natives, the last of whom died in 1877 , represented most nearly Palæolithic man in build and manner of life. They had been driven from Australia by the present aborigines, a race superior to them in intelligence. They were hunters; their weapons were of stone or wood; they wore no clothes and had no houses; and they wandered about in search of food, and sheltered themselves from the winds by rude screens made of bark. The Bushmen of South Africa are apparently very similar to other types of Palæolithic men, and in particular made the same kind of mural drawings. Some of the later Palæolithic men were very much like the modern Eskimo.

These Palæolithic men left their remains and weapons all over temperate Europe, but they died out or were exterminated, and the pastoral Neolithic folk took their places. But even the relations of Neolithic man to the present race are not always clear, and we must 
therefore briefly study the distribution of the present races of men as we find them, independently of any history.

Four chief races are recognized, with many subvarieties and groups of mixed origin. These may have developed in the later Neolithic and bronze periods, when it is thought the general typical characteristics became somewhat settled. The four commonly accepted races are: (I) the Ethiopic or Negro; (2) the Mongolian or yellow ; (3) the American or bronze ; (4) the Caucasian or white.

The Ethiopic or negro originally inhabited Africa south of the great deserts, and Madagascar; also Malaysia, the Philippines, New Guinea, and Australasia. In modern times this race has spread somewhat over Northern Africa, and has been transplanted (chiefly as slaves originally) to the Southern United States, the West Indies, Central America, the Guianas, and the coastlands of Brazil.

In this race the head is long, the nose broad and flat, the lips thick and everted, the eyes large, round, and prominent, the hair short, black, and woolly. In temperament they are fitful and generally unprogressive and unintellectual; with few arts, and little religion beyond nature worship and ancestry worship. The Eastern negroes are more cruel and barbarous than the African or Western sections.

The Mongolian or yellow races originally came from the vast plateaux north of the Himalaya. They have spread into Indo-China, Malaysia, China, Japan, Turkestan, Asia-Minor, Turkey, and Hungary; they have relatively short heads, and very small concave noses, thin lips, small oblique black eyes, and long, coarse, black hair. In temperament they are indolent and sullen in tropical regions, but industrious, though 
suspicious in the temperate zone. They are mostly Buddhists and Mohammedans.

The American or bronze race originated in the New World, to which they are still confined, possibly having been an offshoot from the Mongolian race. They have diminished in numbers very greatly since the fifteenth century. They are being " preserved" in certain reserves in the United States and Canada. In South America many tribes are still independent. The men of this race are impassive and wary; their religion is nature worship or some form of polytheism.

The so-called Caucasian or white race seems to have originated in Northern Africa or Western Asia and to have spread in early times all round the Mediterranean Sea ; then it spread over Europe and into Persia and India. In quite modern times the race has peopled much of North and South America, South Africa, Australia, and New Zealand.

The Peoples of Europe.-This continent is inhabited almost entirely by "Caucasian" people; the exceptions are the Turks, Bulgars, Hungarians, Lapps, and Finns, who are Mongolian people. Modern study recognises three divisions which do not correspond with languages. The first, and probably the oldest, " race" is the Mediterranean. This race came from North Africa, probably in Neolithic times, and the ancient Egyptians and the modern Berbers are African branches of the race.

Other branches of this race invaded Europe across the three routes where the sea is most easily crossed. The Iberians crossed by the Straits of Gibraltar and occupied the peninsula. The Ligurians crossed over Sicily and occupied almost the whole of Italy. They passed along the coast until they came into conflict with the Iberians in the south of France. The Pelasgians, 
the third group, came across the eastern Mediterranean and reached Greece and the islands. Mediterranean Man established himself round the great inland sea, probably displacing earlier races of Palæolithic or early Neolithic types. He became thoroughly adapted to the environment of hot, dry summers; and his adaptation has enabled him not only to retain nearly all his early conquests, but also to extend north-westward along the Atlantic seaboard until he had peopled France and most of the British Isles. This race includes the Romance-speaking and Celtic-speaking peoples of South-Eastern and Western Europe.

Possibly from Mediterranean man, and perhaps in later Neolithic times, there developed an offshoot adapted to the forest lands of Central and North-Western Europe. This is Nordic Man, a race tall in stature, with fair hair, blue eyes, and light complexion, in contrast with the lower stature, dark hair, and dark eyes of Mediterranean man. It has been suggested that Nordic man originated as such in Scandinavia; that is, Scandinavia in the wider sense, including Denmark. This race was as perfectly adapted to the moister conditions, to the deciduous forests, coniferous forests and marshes as Mediterranean man was to the dry summers and irrigated alluvial plains of his region. This northern and north-western race is like the Mediterranean race in having a relatively long skull - a most important similarity, and one which divides him sharply from the next race to be considered.

Alpine Man.-Mediterranean man belongs, broadly speaking, to the peninsulas and islands of Southern and Western Europe; Nordic man belongs to the lower hills and the plains of Northern Europe and the northern peninsulas and islands. In Middle Europe is the great wedge of newer mountains, of which the Alps are the 
culmination. Into this region came a great intrusion from the East, a race of man from the great Eurasian plains, probably from beyond the Urals and the Caspian. The men of this race were broad-skulled, or round-skulled as some writers say, and of intermediate colouring. The broad-headed men seem to have pushed themselves right across Europe to the Pyrenees. The race penetrated to Britain, if the evidence of bronze implements and of their peculiar barrows (burial mounds) may be trusted. Broad-headed skulls are comparatively rare among the modern British population, and it is believed that Alpine man was only present for a time as a ruling caste in Britain, to be ultimately absorbed in the general population.

Alpine man, as represented by the broad-skulled elements in the population, now extends from Belgium across southern Germany to Austria and Russia. He also inhabits the Alps and the adjacent highlands of the northern Balkans. He was essentially a pastoral man, of nomadic habits, which he had acquired by long adjustment to the environment of the steppes. Except that he has adapted his pastoral habits to the Alps, and modified his nomadic habits to suit his herdsman's life there, the name Alpine is not a very happy one. Eurasian is better, and some writers have used CeltoSlavic. The old name Slavonic is obviously included in this more modern race-name.

We have thus a picture of Europe inhabited mainly by three varieties of the Caucasian race, Mediterranean, Nordic, and Alpine, with intrusions of Mongolians in Turkey, Bulgaria, Hungary, and Finland. If this modern reading is correct, it is obvious that the connection between race and language is only slender and uncertain, and that it cuts across nationality in many directions. The British Isles may be taken as illustrat- 
ing one of the peculiarities of language and race. Early Mediterranean man had his own language, which has become extinct in Britain. Alpine man came as a ruling class and imposed his Celtic on the earlier inhabitants. Afterwards, across the North Sea, came successive invasions of Nordic man, and again these almost completely imposed their language on the British people. Very nearly the converse has happened in one part of Central Europe. Bohemia is inhabited by Alpine man, but he largely speaks a Nordic language (modern German). There is a Slavonic movement for preserving the Czech language, and in the capital, Prague, there is a Czech university as well as a German one.

A most interesting case of one "race" with different languages is furnished by the Iberian peninsula. That region is geographically well fitted to become the home of one race, and with the exception of some Moorish strains it is almost pure Mediterranean in type. Yet no less than four languages are spoken, all of them probably of Mediterranean origin : Castilian or Spanish, Portuguese, Basque, and Catalan. Catalan and Basque overlap somewhat into France at either end of the Pyrenees. ${ }^{1}$

It would take too long to study the rest of the Great Caucasian race as fully as the branches in Europe have been discussed. It may be remarked, however, that two great linguistic families are recognised: Southern Caucasian and Northern Caucasian. The southern family includes the groups called Hamitic and Semitic, those inhabiting Mesopotamia, Arabia, Egypt, Northern Africa generally, and the south of Spain. The northern family includes the Indo-European or Aryan groups, inhabiting nearly all Europe, Armenia, the Plateau of Iran,

${ }^{1}$ For a study of the Basque problem, see Ripley's The k'aces of Europe. 
Afghanistan, and Northern India, with the well-known offshoots into America, South Africa, Australasia, etc.

It is interesting to note that the three great monotheistic religions arose among the Caucasian peoples : Judaism, Christianity, and Mohammedanism. Relatively few Caucasians have remained polytheistic, the chief exception being the Brahmins of India.

There are naturally many parts of Europe where there has been some fusion of the sub-races, and where there has been long-continued struggle for domination : One such region is where the plain of Russia approaches the middle mountains of Europe ; there some fusion of the Slavonic division of the Alpine race with Nordic man has taken place, and there the struggle between Panslavism and Pangermanism is very keen. In the region immediately to the west of the Rhine is the fundamental antagonism between the two races, Mediterranean and Nordic. In the British Isles there has been a fusion of the long-skulled, darkhaired race with the long-skulled fair-haired race; that is Mediterranean with Nordic, and at least some infusion of the broad-headed Alpine race. At one time it was almost an article of faith to believe that the Nordic overwhelmingly predominated, but opinion has changed considerably of late years, and now the mixed British people are believed by many to be predominantly Mediterranean, with a strong but subsidiary infusion of Nordic, and some leaven of the Alpine. This is usually believed to have been of advantage.

New racial combinations of great interest and probably of great power seem likely to arise in the future in the "New Countries," such as Canada, the United States, Argentina, Chile, South Africa, Australia, and New Zealand. To take North America as an example. It was first colonised largely by Mediterranean man, then 
afterwards the other European sub-races and the mixed peoples have contributed their share. There has been interfusion in varying degree with a remnant of the original American, a strong Ethiopic strain added, and also a considerable infusion of Mongolian blood. The results of such a commingling of races and subraces cannot be foreseen.

Nations, Races, and Languages in Europe--Not one of the great nations of Europe is composed of a race in the strict sense, but in most cases one or other of the three great European " races" predominates. Spain is, as we have already seen, almost entirely Mediterranean, with some intermingling of a foreign element, the Berber (or Moorish); France is also predominantly Mediterranean, but not to the same extent as Spain, for there has been a considerable infusion of Nordic and a powerful leaven of Alpine. Germany is predominantly Nordic, with some Alpine in the south and another strain of Alpine (Slavonic) in the east; Italy is Mediterranean, with some Nordic in Lombardy and Alpine in the north-east. Russia is predominantly Alpine, but there are quite foreign elements of various types, Finnish and Kirghiz being the most obvious. Austria-Hungary was in no sense a nation as determined either by predominance of one race, or as limited by geographical boundaries. It was simply a creation of the diplomatists, and proved to be essentially unstable. Germans inhabit the Valley of the Danube in and near the Austrian Gate. Vienna is the centre of the Germanic lobe. As already mentioned, Bohemia is inhabited by Czechs-a Slavonic peoplewho speak both German and a Slavonic tongue. The racial question is very acute in that part of Central Europe. The great Hungarian plain is inhabited mainly by Magyars or Hungarians, a people of Uralo-Altaic (i.e. 
Mongolian) race. North and north-east of these are Slovaks and Little Russians, both Slavonic peoples, speaking different languages from the Hungarians and Austro-Germans. In eastern Hungary there is Transylvania, inhabited mainly by Roumanians, speaking a Romance language. In this division of Hungary alone there are said to be five "nations," five languages, five creeds-an interesting epitome of the inherent difficulties of the recent Austro-Hungarian Monarchy. The southwestern divisions, Bosnia and Herzegovina, are peopled by Southern Slavs, as also are Croatia and Slavonia more to the north. Italians are predominant in the Trentino, in the coast lands of Istria and in southern Carniola. In addition to these dominant divisions it must be remembered that strong German colonies are scattered through many of the larger population areas, especially in Hungary and in Transylvania.

Four religions are strongly represented-the Greek Church, the Roman Church, the Protestant, and Jewish. The Czechs of Bohemia are Romanists, that religion having been forced on them in the early seventeenth century, in the Thirty Years' War from I6I8 to I648. The Poles of Cracow and western Galicia are also Romanists. The Little Russians are devoted adherents of the Greek Church, as are also the eastern groups of the southern Slavs. The western Slavs of the Southern group-Croats and Slovenes, nearer to the Adriatic, are Romanists. The Roumanians are chiefly of the Greek Church, and the Magyars are chiefly Protestants. German-Austria is essentially Romanist in religion. 


\section{BIBLIOGRAPHY}

There is an immense literature dealing with the subject of this chapter. The following is a selection :

(I) Anthropology. R. R. Marrett. Home University Library. Williams \& Norgate.

(2) The Dawn of History. J. L. Myers. Home University Library. Williams \& Norgate.

(3) The Study of Man. A. C. HAddon. J. Murray.

(4) The Races of Europe. W. Z. Ripley. Kegan Paul, Trench, \& Co.

(5) The World's Peoples. A. H. Keane. Hutchinson.

(6) Ancient Hunters and their Modern Representatives. W. J. Sollas.

(7) Prehistoric Man. Duckworth. Cambridge University Press.

(8) The Human Species. A. DE Quatrefages. International Scientific Series. Kegan Paul, Trench, $\&$ Co.

(9) Man before Metals. N. Joly. International Scientific Series. Kegan Paul, Trench. \& Co.

(ro) The Descent of Man. Charles Darwin. J. Murray. 


\section{THE DISTRIBUTION OF POPULATION AND THE LOCATION OF TOWNS}

THE first need of man is food, and the amount and accessibility of food-supply is the first factor in determining his distribution. As his wants increase with advancing civilisation, other factors connected with clothing, recreation, and pleasure become important. The luxuries of life as well as the pure necessities nowadays play an increasingly important part. Food can be transported with such relative ease compared with former times, that man need not dwell so near the region where his food is produced as formerly. Even yet there are, however, some of the densest aggregates of population where staple foods are produced in large quantities. The relations between man and the food-supply are reciprocal; a dense population grows up on certain favourable fertile lands; and the people produce on these lands every available particle of food, according to their knowledge. This reciprocity is well illustrated in the densely peopled lands of China and India, to which further reference will be made later.

Highly civilised communities have usually passed through three stages in relation to their food-supply and other wants. In the earlier times they are pastoral and more or less nomadic, moving from one region to another as the food-supply for their flocks fail. After this they have become agricultural and settled, and the 
cultivation of grain, roots, and fruits adds to their simpler resources. Finally, they have become commercial and industrial, producing commodities other than foods in exchange for imported supplies of the latter.

The typical nomads are found, of course, in deserts and on steppes and prairies. The inhabitants of the Kirghiz steppes of South-Western Asia live almost exclusively on the products of their flocks and herds, seldom using even bread. Their food is flesh and cheese, and their drink fermented milk.

The agricultural stage is illustrated by many young nations, such as Canada, Argentina, Australia ; and by the peoples inhabiting the rich alluvial plains, such as the Yangtse, the Ganges, the Nile. England has fully reached the industrial stage, and the British Isles, as a whole, produce only a comparatively small proportion of the food required by their people. England was an agricultural country until the industrial revolution of the eighteenth and nineteenth centuries, and between say I700 and I90o has passed quite from one stage to the other. Germany was predominantly agricultural until quite recently, but of late years much food has had to be imported. Even a young country like the United States is apparently passing from the agricultural to the industrial stage. It would, however, be better to regard the United States not as a country in this respect. It is rather to be regarded as a federated continent, some portions of which are pastoral, some agricultural, and some industrial.

In the nature of things population can never be very dense in the pastoral or nomadic stage of development, and all such regions are but sparsely peopled. Some agricultural regions and most industrial regions are densely peopled. The distribution of population ultimately depends upon climate, fertility of soil, mineral 
wealth, and means of intercommunication, using the latter term in its widest sense. The four factors mentioned are of very different values in different regions; and are usually closely interrelated.

Thinly Peopled Lands.-It may be well to indicate, at the outset, some of those regions where population is very sparse; these are: some parts of the hot, wet, tropical forest ; tropical deserts, deserts in the temperate zones, the tundra, the Arctic Highlands, and some high mountain regions and very high plateaux in various parts of the world.

In the hot, wet forests the undergrowth is so dense that communication is very difficult except on the rivers. The soil consists largely of decomposing vegetation, the air is laden with disease germs, and germ-bearing insects abound; little sunlight penetrates the overhead canopy of vegetation, and the glades are gloomy and depressing, and poisonous insects, venomous snakes, and beasts of prey make human life insecure. The dense equatorial forest is, therefore, the home of a few degenerate American Indians, or Negroes, or Malays.

The deserts are permanently inhabited only on the oases, the latter being determined by a spring or a deep well. The Nile Valley is a long narrow oasis in an almost rainless region; it is, of course, the river that is entirely responsible for the habitability of lower and middle Egypt. In a somewhat lesser degree this is also true of the Mesopotamian valley, and of the lower Indus. Outside the oases there are only a few nomads who move from one fertile spot to another. The great Sahara is the conspicuous example; there an area of three million square miles (that is, three-fourths the size of Europe) contains probably at most little more than one million people. Arabia, the highland deserts of mid-Asia, and the Australian desert are also very thinly peopled. 
Beyond the Arctic Circle human habitation is diffcult and the number of inhabitants very small. The continued absence of sunlight during the long winter lowers the vitality of man; food is very scarce, most of it coming from the sea; and there is little to attract the average man. The population is confined to a few Eskimos and similar tribes, who eke out a very precarious subsistence. The Lapps of the far North of Europe, who have the advantage of the gulf of winter warmth caused by the Atlantic drifts and the warm south-westerly winds, are the most advanced of Arctic peoples. Some of them are settled on the northern fiord coast and maintain themselves by fishing; the others are nomads who inhabit the interior, and with their dogs and reindeer wander from place to place in search of pasture for the latter animals. Assuming that the known lands in the Antarctic regions are parts of one great Antarctic Continent, there may be a land mass in the far south with an area almost or quite equal to that of Australia. So far as is yet known, there are no land mammals whatever, and of course no human inhabitants. There are numerous species of birds, and seals and whales are plentiful in places. There does not seem to be any land flora. This, therefore, is almost the largest absolute desert on the earth's surface.

Greenland may serve as the type of Arctic highlands. The land is fringed with fiords like many of the northern lands, and Eskimos inhabit the coast up to about $78^{\circ}-80^{\circ} \mathrm{N}$. It is estimated that there are about 10,000 Eskimos in the whole of Greenland, together with the few Danes who administer the country and carry on its foreign trade. The great inland plateau of ice, which stretches nearly from coast to coast, is uninhabited.

Lastly, among the sparsely inhabited regions may be 
mentioned the high mountains and plateaux where either Arctic highland or tundra conditions are reproduced. Above the snow-line permanent inhabitants must obviously be very rare. A little below the snowline are only a few herdsmen, except in regions such as Switzerland and Norway, where nearness to the dense population of industrial Europe has made of the mountains a playground, and where hotel-keepers, guides, and a few others depend upon the increasing number of tourists who visit the mountains in search of knowledge, pleasure, or adventure. The higher parts of the great Tibetan plateaux, alike with the neighbouring Alpine mountains, such as the Pamirs and Karakorum, form another great region with a sparse population. The intense cold of the winter, the icy blasts, and the low atmospheric pressure, combine to render such lands almost uninhabitable.

Densely Peopled Lands.-We may now turn to the other extreme, where large populations are concentrated on a small area. There are clearly two main types. First, those lands where food is plentiful and cheap, and where a rich soil and a favourable climate produce enough to satisfy the needs of a large, if not very exacting, population. The plains of China at once occur as illustrations. The rich alluvial soils of the Si-Kiang, the Yangtse, and the Hoangho valleys, and of the coast lands support an enormous population. The summers are regularly hot and moist, controlled by the monsoons which blow from the warm seas. Agriculture is regular and the climatic conditions reliable, and almost every inch of the rich soil of the great alluvial plains is utilised. The winters are dry and comparatively cold, and a period of rest for the worker and for the land is insured. Under these conditions there has come to be the densest population of agri- 
culturists and almost vegetarians that the world knows. The plain of the Ganges and the Punjab part of the Indus are similar. The alternation of warm, wet summers and dry "winters," coupled with the wonderful fertility of the immense stretches of rich alluvial deposits, cause the enormous agricultural wealth of India, and are largely responsible for the vast population of the plains. In Bengal and the United Provinces (Agra and Oude), with an area of 186,000 sq. miles (that is, 21,000 sq. miles less than France), there is a population of $92,000,000$ (cf. France again with 39,000,000). ${ }^{1}$ Most of this enormous population is dependent upon India's chief industry, which is now, as it always has been, agriculture.

A remarkable example of a densely-peopled agricultural land is that of the lower Nile trough, set in the great desert. If the desert areas of Egypt are included the population of the country works out at about I2 to the square mile. If the desert be excluded the density is nearly 600 to the square mile, which is very high. The rich silt of the overflowing Nile, deposited over the land from before the dawn of history, has made the support of a dense population possible. As the marshes of the delta are drained and reclaimed this population tends to increase. At present an area of I2,000 square miles supports a population of over II,000,000. Yet another example of a densely peopled agricultural region is the plain of Lombardy. The rivers of the Alps and the Apennines have spread over the sunken block an immense thickness of mixed debris, which has come from the varied geological formations of the mountains. Wheat, maize, and rice are grown in large quantities and support a large population. This

1 Of course there are many relatively infertile parts of France included. 
region is not so purely agricultural as the others mentioned, for manufactures are carried on chiefly in the towns; silk, woollen, and linen spinning and weaving giving employment to a considerable number of people.

All these examples of dense population are of long standing, but there are other thickly peopled regions which are quite modern in origin, and are characteristic of modern civilisation. These are the industrial regions, usually located on or near the coal-fields. The great industrial region of east and south-east Lancashire may be taken as a type. Here the soil is infertile and the climate far from attractive. The rainfall is not heavy, but it is distributed throughout the year, three days out of five having some rain. There is much cloud and consequently not much sunshine. Yet there is aggregated a very closely packed population, chiefly engaged directly and indirectly in coal-mining and cotton manufacture, and the allied engineering and chemical industries. Here is a population of from five to six millions, and the commercial capital, Manchester, has become a focus for almost ten millions of people. It is somewhat outside the scope of the present work to discuss fully the reason for the localisation of industries, but it may be stated briefly that in Lancashire some of the determining factors have been coal, nearness of salt (for chemicals), a humid atmosphere, and plenty of small rivers with soft water from the grit hills.

Other industrial regions with dense populations are the Midland Valley of Scotland, the North-Eastern region of England (Blyth to Middlesbrough), the West Riding with an extension into Derbyshire and even to Nottingham, the great Midland region with Birmingham as a centre, and the South Wales coal-field.

To these, which are largely determined by the presence or nearness of coal, and which are essentially products 
of the Industrial Revolution, may be added Greater London with its 7,000,000 of people, its great and varied industries, its immense shipping trade, and its vast financial interests. London's convenient river mouth, its excellent position facing the continent, its choice in early times as the capital of a progressive country, and perhaps above all the daring foresight and industry of its merchants, have made it the world's greatest port and commercial and financial clearinghouse. The county of London, with Croydon, Rickmansworth, Watford, St. Albans, and many other towns and villages, are all part of greater commercial London, and the extension of electric trains and motor buses is drawing a still wider area into the always extending London.

On the Continent of Europe the chief industrial regions with dense populations are : Belgium, especially south Belgium, in the Sambre-Meuse Valley, where a coal-field extends almost continuously across the country from north-east France to Aix-la-Chapelle. From Lille and Roubaix, through Tournai, Mons, Charleroi, Namur, Huy, and Liège to Verviers and Aix is one busy manufacturing region, with intervals in the dolomitic limestone region of the Meuse, between Namur and Huy, where the population is not so dense as in the other parts. In addition to the coal on the spot there are iron ores not far away, and zinc ores in the vicinity. The rivers Meuse and Sambre and the magnificent system of railways and canals, complete the facilities for transportation. The Westphalian region, in the valleys of the Ruhr and the Lippe, is another busy industrial province, where great iron, textile, and chemical industries are located. The coal of the district is used to smelt the iron brought down the Rhine from Lorraine and Luxemburg, and much ore now comes from abroad. In the immediate district 
there is a population of about $3,000,000$, and a dozen towns of over I00,000 each, thus making a district almost comparable with East Lancashire. The chief towns of that busy region are Düsseldorf, Essen, Duisburg - Ruhrort, Dortmund, Elberfeld, Barmen, Bochum, Crefeld, and Mülheim. In a part of Saxony is one of the densest populations of Europe, where $5,000,000$ people are condensed on about I5,000 square miles. There are found coal and lignite, and much metal-mining is carried on even yet, though the mines have been worked for centuries. There has also grown up a great textile industry, in some measure a rival of that of Lancashire and the West Riding of Yorkshire. Add to these the manufacture of locomotives, machinery, and chemicals, and it will be understood how a great industrial region is located there, the chief towns of which are Leipzig, Dresden, Chemnitz, Meissen, and Zwichau.

The last of the great industrial regions which we shall discuss is that of the coal-field of Pennsylvania and Ohio. Pittsburg may be taken as the centre of the immediate busy manufacturing region. It has immense iron and steel works. The original ore of the district has been nearly worked out, but ore is now brought in enormous quantities from the Lake Superior region. There is abundance of coal, and there are also the large stores of petroleum. To these advantages of raw materials in great bulk must be added the facilities for transportation. The Great Lakes, the Erie Canal connecting to the Mohawk Valley and to the Hudson, and the excellent railway systems give ready facilities for communication with the Atlantic seaboard, with Canada, and with the rich agricultural lands of the interior. It will be readily understood how this has come to be North America's busiest district and the 
region of its densest population. The greater region now under consideration includes the following cities : Pittsburg $(534,000)$, Buffalo $(424,000)$, Cleveland $(561,000)$, Detroit $(466,000)$, Cincinnati $(364,000)$, Columbus (I8I,000), Toledo (I68,000), and Dayton (II7,000).

All these great industrial regions are situated on coalfields or not far from coal supplies, and where the means of communication and transport are excellent. In the present stage of industrial development coal is the strongest factor, but it does not follow that this advantage will be maintained. Already there is taking place a great development of electrical power derived from water-supply. Norway and Sweden, the hilly regions of Saxony, Switzerland, Eastern Canada, and the United States have so far led the way. Power is now transmitted for great distances in both Switzerland and the United States, and this may lead to new distributions of manufactures and of population in the future.

The Location of Towns. - When man passes out of the purely nomadic pastoral stage he needs permanent settlements. Towns therefore grow up where he can exchange his commodities, and in the earlier agricultural stage where he can receive protection for himself and his property. Towns were usually begun in places which could be easily defended, either by means of a commanding fort or by placing the town where it would be safe from attacks. Athens, Edinburgh, Carcassonne, Lincoln, Stirling are famous towns which were under the protection of hill forts. Many towns were built on islands, examples of which are: Paris on an island in the Seine, Ely on an "island" in the Fenland, Venice on an island among lagoons, and Bombay on an island in the sea. Many towns have grown upon land in bends of rivers, where they would be relatively 
difficult to attack: Durham, Toledo, Besançon, are examples.

Another type of town is where routes meet, and of these there are numerous examples. A simple case is where break of bulk occurred owing to a great mediæval roadway crossing a river, and in the case of such towns as Oxford, Hereford, Utrecht, the name refers to the crossing. The old Watling Street of England passed through Fenny Stratford and Stony Stratford. Other well-known English examples are Stratford-on-Avon and Watford. Strassburg stands where the old Crusaders' route passed round the northern end of the Vosges towards the crossing of the Rhine. Orleans stands where the route from Paris to the south crossed the Loire, and numerous other examples might be given.

Confluence towns are perhaps more numerous than any other type ; they are found in all types of civilisation, eastern and western, ancient and modern. The simplest case is where two navigable rivers meet, or two rivers which determine roadways through a country. Reading, Lyons, Namur, Allahabad, Khartum, Hankau, Montreal, St. Louis, may be investigated by the student. The simple crossing of well-used routes provides another group of towns. Vienna on the crossing of the east to west and north to south routes is a good example. Liège is another case where two important mediæval routes crossed, and in modern times important railways cross at the same place.

Important towns often stand where intermont valleys open out into a plain. Consider those eastern Pennine rivers which make up the Yorkshire Ouse. At the "mouth" of the Swale is Richmond; on the Ure is Ripon; on the Nidd, Knaresborough; on the Wharfe, Tadcaster; on the Aire, Leeds ; on the Calder, Wakefield; and on the Don, Doncaster. It is interesting to note 
the difference in development between Leeds and Wakefield on the coal-field and the northern group, which are still comparatively quiet market towns. Doncaster is becoming a great coal centre, though it is not on a coal-field on the geological map. A " buried coalfield " is responsible for its very recent growth.

Perth, Stirling, and Dumbarton are similar gateway towns to the routes into the highlands. Cologne, Liège, and Namur are of this character, as also are Turin, Milan, and Verona.

A large number of famous towns occur at the tidal limits of estuaries ; that is, at the farthest point to which early shipping could penetrate, which was often also the lowest point where the river could be easily bridged or forded. London is a classic example. Bristol, Newcastle, Hamburg, Bremen, Nantes, Bordeaux, may be mentioned among others. As modern shipping has grown bigger and bigger, the trade has either left many an old tidal port, or an outport has enabled the older town to maintain its ground. Glasgow, Newcastle, London, Bristol, Hamburg, Bremen, Nantes, Bordeaux, have all important outports.

Havre has developed as a great port of France because it is on the open sea. Southampton and Liverpool need no outports. In non-tidal seas, towns very often stand on bays or natural harbours, examples being Marseilles and Naples.

The towns at the ends of the drowned valleys on the eastern seaboard of the United States have already been mentioned. Washington, Baltimore, Philadelphia', and Trenton stand just at the head of easy tidal navigation, where the rivers open out into a wide estuary.

Geography can thus explain from obvious natural causes the position of many types of towns. There 
are others which are due to what may be called more artificial causes. Towns where mineral wealth is the first consideration, such as Johannesburg, Wigan, and Coolgardie, may be taken as examples. Rome and Mecca owe much to religious sentiment, without which (especially in the case of the latter) they could scarcely have retained their importance in modern times. Petrograd and Berlin owe much to determined princes who resolved to make them into capitals of kingdoms or empires. Washington and Ottawa have been selected as capitals of federation of states, and in both cases the work of administration maintains a considerable population.

Modern industrial towns are not always easy to explain. In some cases they are very old towns rejuvenated; Leicester, Derby, Nottingham, Liège are cases in point. Manchester, Leeds, and Birmingham trace their origin back to very early times, but their modern importance is shown by such facts as the late period when they were first represented in Parliament. Not one of them was reckoned as of first-class importance in the Civil Wars of the seventeenth century. The Ruhr-Lippe group is of similar modern growth. The great industrial towns of the United States are of necessity modern. Their enormous growth is due to the tremendous natural resources of a rapidly-developing continent.

With the great development of railways, and the almost complete dependence of modern industrial life upon them, new nodal towns have in many cases grown up where a system of lines radiate, or the railways have been attracted to old towns, following more or less the routes of the mediæval roads. Of the new centres, Crewe is a good example. Many of the old and important towns have also developed into modern nuclei 
of railway traffic; Rugby, York, Carlisle, in Britain; Namur, Prague, Warsaw, and many others on the Continent, may be quoted. All great capitals are now the meeting-places of numerous railway lines, and thus towns which were before important have added to them a new source of wealth.

Finally, many new towns in new countries owe much of their importance to the railways converging on them. Montreal, Chicago, St. Louis, Winnipeg may be mentioned as American examples.

\section{BIBLIOGRAPHY}

(1) The Relations of Geography and History. H. B. George. Clarendon Press.

(2) Influences of Geographic Environment. E. C. Sem PLE. Constable.

(3) Human Geography in Western Europe. H. J. FleURE. Williams \& Norgate.

(4) The River of London. H. Belloc. Foulis.

(5) Industrial and Economic Geography. J. R. Sмгтн. Constable.

(6) Economic Geography. J. M'Farlane. Pitman \& Sons.

(7) And the Handbook of Commercial Geography, by G. E. Chisholm; and Lyde's Europe, already quoted in earlier chapters. 
$\because \quad \cdots, \ldots$,

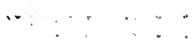




\section{A P P E N D I X}

\section{QUESTIONS SELECTED FROM THE EXAMINA- 'TION PAPERS IN GEOGRAPHY SE'T BY VARI- OUS WELL-KNOWN EXAMINING BODIES.}

THE student is recommended to spend considerable time in this series of questions. It is hoped they will serve the double purpose of assisting him to fully understand and assimilate what he has read, and stimulate him to thought which may carry him beyond the limits of the book. It is not pretended that every question may be fully answered from this book; and it is exactly those questions which are worth the more serious consideration of the student.

A study of question 60 on an isothermal line-using a good map showing those lines-will help the student to fully grasp some of the most important factors of climate. So also a study of the thoroughly' good question I 37 is one of the best possible exercises. In studying a question such as II3, the student will be considerably helped by making a "graph " of the rainfall for the three places. These are, of course, only examples. To the keen student other methods will readily occur.

To the student who wishes to see fuller collections of questions it may be pointed out that some of the series are published regularly in book or pamphlet form. The papers set at Oxford Senior Local and Oxford Higher Local are published by the Oxford University Press; those set at the various London University Examinations are published in extenso by the London University Press, Ltd., St. Paul's House, Warwick Square, London, E.C.--from whom they may be obtained. 


\section{QUESTIONS}

\section{SECTION A.-STRUCTURAL GEOGRAPHY}

\section{OXFORD SENIOR LOCAL}

I. "Lakes are transitory features of a region." Explain carefully why this must be so. What are the various economic uses of lakes? Give examples.

\section{OXFORD HIGHER LOCAL}

2. Compare the distribution of land and sea in the Northern and the Southern Hemispheres. State some of the consequences of these facts.

\section{CAMBRIDGE SENIOR LOCAL}

3. Describe the physical characters of the west coast of Ireland, and point out any resemblances and differences between it and the west coast of Scotland.

4. Describe and explain the characteristic features of the principal types of coast-lines, and mention an example of each.

5. Describe the physical character of the coastal region of the United States between Florida and the Bay of Fundy, and show how it has influenced the progress of colonisation and subsequent development of the country.

6. Describe the mountain systems of South America.

7. Give some account of the Lakes of Asia.

\section{UNIVERSITY OF LONDON : MATRICULATION}

8. Give an account of the Geographical distribution of active and recently extinct volcanoes. Describe the characteristic features of a volcanic district.

9. Give an account of the distribution of volcanoes in the Pacific region. Describe the characteristics of some of the more important volcanoes of that region. 
Io. Describe and explain, as far as you can, the physical character of the west coast of the mainland of Europe, from Southern Norway to Brittany (excluding the Baltic coast).

II. Describe the physical characters of the Mediterranean Sea and its northern coast. Compare the Mediterranean Sea with the Gulf of Mexico.

I2. Describe, or show by a sketch-map, the position of the chalk hills around the London Basin on the north, west, and south. Indicate the places where the main lines of railway cross this chalk rim.

13. Give a description of the characteristics of the mountain systems of Europe.

I4. Give a description of the characteristics of the mountain systems of Asia.

15. What are the principal types of mountains? Mention examples of each. Explain, as far as you can, the way in which each type has been formed.

I6. Write an account of the physical geography of the Himalaya.

I7. Describe the physiography of the Highlands and Western Islands of Scotland.

I8. Describe the principal types of mountain structure and give illustrations of each.

19. Explain the structure of the Weald, and its relation to the drainage system of the area.

20. In what regions of the world does the drainage find no outlet to the sea? Describe the characteristics of one of these regions.

2I. Describe the characteristics of the principal types of lakes. Mention an example of each type.

22. Describe, and, as far as you can, account for the position of the chief lakes of Ireland, mentioning the rivers with which each is connected.

23. Describe the conditions necessary for the formation of $(a)$ a delta ; $(b)$ an estuary. Illustrate your answer by reference to examples.

24. In what ways have plains been formed ? Describe the characteristics of extensive plains in Europe and North America. 
25. What is "loess"? What do you know of its distribution in Europe and in Asia?

26. Describe briefly the extent and character of the Continental Shelf on which the British Isles are situated, and state what advantages these islands receive from such a situation.

\section{UNIVERSITY OF LONDON : INTER. SCIENCE, ECONOMICS}

27. Correlate the coastal features of the Eastern States (U.S.A.) with the character of the land behind them.

\section{UNIVERSITY OF LONDON : INTER. ARTS}

28. Describe the Continental Shelf and discuss its economic importance.

\section{UNIVERSITY OF LONDON : B.A.}

29. Discuss, with illustrations, the importance of the conception of an erosion (or topographical) cycle in the study of land forms.

30. Draw a map and sections of the Pennine Chain of England to show its limits, divisions, and shape. Point out how the topography has determined the course of the chief railway routes across it.

3I. Describe and account for the shapes of the sides and bottoms of Alpine valleys, and the development of such a valley system as that of the Rhone basin above the Lake of Geneva or of the Rhine basin above the Lake of Constance.

32. Describe the two great mountain nodes of Asia, and the courses of the mountain systems which meet in them.

33. "Between the Bay of Biscay and the main streams of the Vistula is a succession of blocks and basins bordered on the north by lowlands which rise to the heights fringing the English Channel, the North and Baltic 
Seas." Discuss this statement and show how far it can be justified.

34. Compare the physical features of the Alps with those of the Scandinavian Highlands, and account for both resemblances and differences.

35. Describe the character of the chalk-scarped ridges in the South of England, and of the gaps through them, noting the utilisation of these gaps as lines of movement, and the position of the more important gap towns. Illustrate your answer by a sketch-map.

36. Describe the structure and physical history of the north German Plain, and trace its influence upon the direction of the rivers which cross it.

37. Write an account of the various types of Lake basins and give examples.

38. Distinguish between the Atlantic and Pacific types of coast, and give any explanation you can.

39. Compare North America, east of the Rocky Mountains, with Europe west of the Urals and north of the Alps, as regards physical structure and configuration.

40. Describe the shape of the ridges and valleys and their general arrangement in such a mountain system as the Central Alps, and give as full explanation as you can of the phenomena described. Draw plans, profiles, and sections to illustrate your answer.

\section{SECTION B.-CLIMATIC GEOGRAPHY}

\section{OXFORD SENIOR LOCAL}

4I. Name and describe the planetary wind systems of the Northern Hemisphere. What are the causes which modify the planetary circulation in Western Europe? What modifications occur $(a)$ in January; (b) in July? How do you account for $(c)$ a strong westerly gale in the English Channel ; $(d)$ a dry east wind in Norfolk? At what times of the year are these most likely to occur?

42. In the Southern Hemisphere the three Continents 
have each an arid region near the West Coast. Name the regions and state the causes of their aridity.

43. What are the chief factors which determine $(a)$ the winter temperature of the British Isles; $(b)$ the rainfall of Southern Europe ?

44. From West to East, Canada may be divided into three climatic regions differing both in temperature and in rainfall. Where would you draw your dividing line? Describe in general terms the distribution of (i) the temperature ; (ii) the rainfall of each region.

\section{OXFORD HIGHER LOCAL}

45. What are the chief factors controlling the climate of South Africa? Explain fully why most of the rain falls during the warmer months of the year.

\section{CAMBRIDGE SENIOR LOCAL}

46. What parts of the British Isles are (a) wettest; (b) driest; (c) warmest in summer; (d) coldest in winter; $(e)$ of least range of temperature? How would you account for the differences?

47. The average January temperature of Cambridge is $38^{\circ} \mathrm{F}$, of Cardigan $42^{\circ} \mathrm{F}$. The average July temperature of Cambridge is $63^{\circ} \mathrm{F}$, of Cardigan $60^{\circ} \mathrm{F}$. The mean annual rainfall of Cambridge is about 25 ins., of Cardigan more than 40 ins. Both of these towns are situated about $52^{\circ} \mathrm{N}$. Lat. Account for these differences.

48. The average January temperature of the Orkneys is about the same as that of the Isle of Wight $\left(40^{\circ}-4 \mathrm{I}^{\circ} \mathrm{F}\right.$.), but the average July temperature of the Isle of Wight is over $62^{\circ} \mathrm{F}$., while that of the Orkneys is less than $55^{\circ} \mathrm{F}$. What explanation can you offer? Which of these places has the heavier rainfall and why?

49. Give some account of the differences in temperature and rainfall in different parts of the British Isles.

50. Contrast the climates of Glasgow and Moscow as regards (i) summer temperature; (ii) winter temperature; (iii) rainfall; accounting for the differences that 
are found. Give the latitude of Moscow, and say what is the time there when it is noon at Greenwich.

5I. Describe and account for the characteristics of the Mediterranean type of climate, and mention the principal regions of the world in which that type occurs.

52. Contrast and account for the climates of the east and west coasts of Canada.

53. It has been pointed out that Japan has a very different climate from that of Britain, the European country with which it is most frequently compared. Describe the climate of Japan, and how it differs from that of Britain. Explain briefly the causes or conditions which determine the climate of Japan.

54. Give some account of the climate of Cape Colony, mentioning any peculiarities in its rainfall. What other part of Africa has a similar climate?

55. Contrast the climates of the Cape York Peninsula and the Island of Tasmania, in both cases explaining the causes of the climate.

56. Give some account of the climate of the southern part of India, with reasons for the facts you give.

\section{UNIVERSITY OF LONDON : MATRICULATION}

57. Give an account of the general arrangement of the winds on the surface of the earth between the Equator and $60^{\circ} \mathrm{S}$. Where are there periodic variations in the arrangements brought about by seasonal changes ? And why do they occur?

58. Give an account of the winds and calms commonly experienced in the following regions:-Doldrums, Trade Wind Regions, Roaring Forties, Horse Latitudes, and draw a diagram showing the positions of these regions upon the earth.

59. How is temperature usually shown on a map ? Give a full account of the various steps by which you would accumulate data for a map of the July temperature in the British Isles.

6o. Trace the course of one important isothermal 
line around the globe, and account for the principal peculiarities which it presents.

6r. What is an isotherm? How do the isotherms of Europe (excluding the British Isles) in winter differ from those in summer? Explain the difference.

62. Describe and account for the characteristics of $(a)$ a Mediterranean climate; (b) a monsoonal climate. Give the geographical distribution of each type of climate.

63. Discuss fully the fundamental considerations affecting the climate of India.

64. Describe and account for the rainfall of SouthEast Asia.

65. Contrast, and explain, the climate of the lands that border the opposite sides of the Atlantic between $5 \mathrm{I}^{\circ} \mathrm{N}$. and $60^{\circ} \mathrm{N}$.

66. Contrast with as much detail as possible the climate of the east coast of Australia with that of the west coast, giving the causes of any differences you mention.

67. Compare the climate of Newfoundland and Vancouver Island. Account for the differences.

68. Describe and account for the distribution of rainfall in India.

69. Describe, and account for, the distinguishing features of the climate of Ireland.

\section{UNIVERSITY OF LONDON: INTER. SCIENCE, ECONOMICS}

70. Compare the climates of England and New England, and explain both the resemblances and the differences.

$7 \mathrm{I}$. State the essential features of a monsoon climate, and illustrate their effects from (a) China and (b) Burma.

\section{UNIVERSITY OF LONDON : INTER. ARTS}

72. What factors determine the temperature of a region? Illustrate your answer by reference to some 
definite country and its temperature both in summer and in winter.

73. Contrast the distribution of temperature over the British Isles in summer with that in winter, and give the causes of the contrasts.

74. Locate, and account for, those areas in the world which have typical summer drought and winter rains.

75. Where, and why, do you find "Mediterranean" climates outside the actual Mediterranean basin ?

\section{UNIVERSITY OF LONDON : B.A.}

76. What are the principal effects of the presence of water or water-vapour in the atmosphere, and of the changes in the condition of water or water-vapour? Intimate parts of the world where the effects referred to are very marked.

77. Mention parts of the world with a more or less elevated seaboard where the climate is $(a)$ very dry; (b) very wet. Explain the differences between the two.

78. Illustrate from North and South America the precise climatic variations due to the movements of the wind system with the sun.

79. Analyse carefully the climates of the following regions and account for the resemblances and differences between them: (a) Nigerian Sudan; $(b)$ the Eastern Deccan ; (c) Southern Japan.

\section{NORTHERN UNIVERSITIES JOINT MATRICULATION}

80. Describe and account for the distribution of temperature over the British Isles in summer and winter respectively.

81. What parts of the British Isles have $(a)$ the rainiest and $(b)$ the most equable climate? In each case state why this is so. 
BOARD OF EDUCATION, CERTIFICATE AND PRELIMINARY CERTIFICATE

82. Why are Western Europe, Eastern Europe, and the Mediterranean lands considered to be distinct natural regions? Name the countries included in each of these natural regions and explain to what their distinguishing features are due.

83. In what parts of the world does a division of the year into four seasons seem inexact and unsuitable? What division would you make in these cases?

\section{SECTION C.-BIOLOGICAL GEOGRAPHY OXFORD SENIOR LOCAL}

84. " Grasslands are usually those regions which are subject either to $(a)$ great extremes of temperatuire or to (b) long droughts." Give an example from the British Empire of $(a)$ and of $(b)$. In each case briefly describe the climate, and the products resulting from these conditions. State as accurately as possible the positions and limits of the areas you select.

85. Select an important wheat-growing region in Canada. State as fully as you can the reasons why wheat is largely produced in it.

\section{OXFORD HIGHER LOCAL}

86. Explain fully why the central part of North America is remarkable for $(a)$ the great variety of its agricultural products and $(b)$ the certainty of the crops.

\section{CAMBRIDGE SENIOR LOCAL}

87. Give an account of the zones of vegetation (in order from north to south) in Russia, and state the natural products of each.

88. Give an account of the vegetation, distribution, and economic importance of tropical forests in South America. 


\section{APPENDIX}

89. Describe the climatic regions of Australia. Mention the vegetable and animal products which are characteristic of each region.

9o. Give an account of the relief, climate, and vegetable products of the Deccan.

9I. Name (a) the principal wheat-growing district; (b) the principal sheep-rearing districts; and (c) the principal cattle-rearing districts in England. State the natural conditions which favour wheat-growing, sheeprearing, and cattle-rearing in the districts you name.

92. Describe the physical character, climate, and vegetation of the great plains of Canada.

93. Into what vegetation belts may Russia be divided? Account for them and broadly indicate their limits. Distinguish between the western and eastern portions of the southern belt, and give reasons for the difference.

94. Draw a map of Australia and indicate the chief physical features. Divide the whole area into $(a)$ forest-land and land affording good cattle pasture ; $(b)$ land suitable for sheep pasture; and $(c)$ desert.

95. In what regions of Asia are (a) tea, $(b)$ rubber, $(c)$ rice, extensively grown? Describe the conditions which favour the cultivation of each.

96. In what parts of North America are $(a)$ cotton, (b) maize, (c) sugar-cane, extensively grown ? Give an account of the conditions which favour the production of each.

\section{UNIVERSITY OF LONDON : MATRICULATION}

97. From what parts of the British Empire do we obtain $(a)$ wine, $(b)$ cotton, $(c)$ tobacco, $(d)$ silk, $(e)$ furs ? Mention the climatic and other conditions necessary for the production of any three of these.

98. Describe and explain the succession of belts of climate and vegetation in Russia from the White to the Black Sea.

99. Describe and explain the succession of belts of climate and vegetation in North America from the Arctic Ocean to the Gulf of Mexico. 
roo. State and account for the sources (excluding North America) from which the United Kingdom imports its chief supplies of meat.

IOI. Describe the distribution of temperate forests, and compare their importance with that of tropical forests.

I02. Give an account of the relief, soil, and climate of the south-eastern United States with reference to the production of cotton.

I03. Explain the relation of the climate to the typical vegetation of $(a)$ France, (b) Egypt, (c) Argentina. I04. Locate, classify, and account for the chief areas of natural forest-lands in the World.

I05. Discuss, with special reference to causes and results, the distribution in Europe of the olive, sugarbeet, and wheat.

I06. State and account for the distribution of rice in the North Temperate Zone.

I07. Give a full account of the conditions that favour the production of wheat on a large scale, and state the chief areas in which it is so produced.

I08. What conditions are necessary for the successful cultivation of cotton? State accurately the areas in which it is produced. Through what port or ports is the produce of each area exported and to what destination does it mainly go ? In what areas has production increased considerably of late?

I09. What are the approximate limits between which the great forest-belt of the Temperate Zone is found ? Say what you know of the character of the forest, and mention the chief forest products.

Iro. In what districts of the British Isles are (i) potatoes, (ii) flax, (iii) hops chiefly grown? Describe the conditions which render the districts you mention particularly suitable for such cultivation.

III. Describe, and account for, the position of the desert regions of the world.

II2. From what plant is cocoa obtained? In what regions and under what climatic conditions is the plant grown? What other important commodities are grown in the same region? 


\section{UNIVERSITY OF LONDON : INTER. SCIENCE, ECONOMICS}

II3. The figures below state in inches the average rainfall for each month of the year at the places named:-

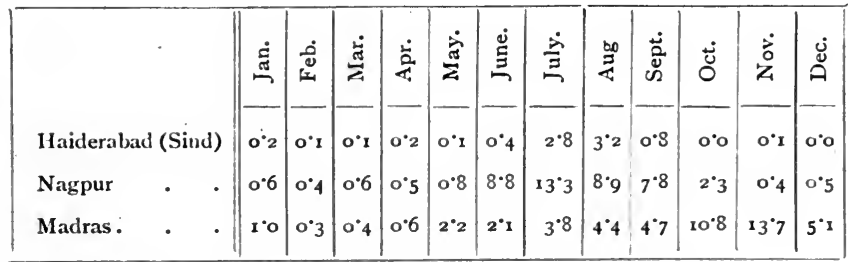

Explain the differences indicated by these figures, and point out how differences in climate affect the condition of agriculture in the regions for which the places named are typical.

II4. Give an account of the climatic and other geographical conditions controlling the distribution of the principal vegetable fibres other than cotton.

II5. Mention the five principal regions which supply the United Kingdom with wheat or wheat-flour or both, and state the circumstances which bring about the great fluctuations from year to year in the relative amounts derived from the different regions.

II6. Discuss the potentialities of Nigeria as a cottongrowing country.

II7. State, and account for, the distribution of the chief flax-growing areas, distinguishing roughly the specifically " oil " from the specifically " fibre " areas.

II8. Discuss, with special reference to the British Isles, how far the productivity of land depends on geological formation.

II9. Discuss the character of the equatorial type of climate, and compare the economic condition of the various lands between the Equator and about $10^{\circ} \mathrm{S}$.

I20. Explain, with reference to climate and soil conditions, the distribution of the chief types of vegetation in European Russia. 
I2I. What are the essential conditions of forest growth? What are the important differences between temperate and tropical conditions?

\section{UNIVERSITY OF LONDON : INTER. ARTS}

I22. Describe the essential geographic conditions involved in the distribution of forest, and estimate the relative value of temperate and tropical forests.

I23. How far, and for what reasons, can you class the Amazon basin and the Congo basin together as natural regions?

I24. From what parts of the world is rubber obtained at present? Describe the conditions under which it is grown, and discuss the prospects of an increased output.

I25. Discuss the relation between the physical structure, climate, and natural vegetative regions of Russia.

\section{UNIVERSITY OF LONDON : B.A.}

I26. Show how an arid and hot climate controls the character of land forms and the nature of vegetation.

I27. Describe and explain the changes in the general character of the vegetation which would be met with in a journey across Africa from the Cape to Cairo.

I28. Describe and explain the characteristics of desert and semi-desert vegetation. Point out the economic value of this vegetation, if any.

I29. Compare and contrast the natural regions of Australia with those of Africa south of the Equator.

I30. Compare Central Canada and Western Siberia with regard to $(a)$ the production of wheat; $(b)$ forest industries.

I3I. Locate, account for, and describe the typical features of the chief areas of savana in the world.

I32. Discuss the geographical distribution of sheep and cattle.

I33. What are the conditions required for the growth of cotton? Consider carefully the possibilities of a greatly increased supply from Africa (excluding Egypt). 


\section{NORTHERN UNIVERSITIES : JOINT MATRICULATION}

I34. Describe the natural vegetation that is typical of the regions with a climate like that of the Mediterranean region; and show how the most characteristic plants are adapted to the climatic conditions.

I35. Into what climatic regions would you divide Canada? State the essential characteristics of each division.

I36. Name the chief wheat-producing areas of the world, and in regard to each give the time at which the harvest occurs and the reason why the harvest comes at that particular time.

\section{BOARD OF EDUCATION : CERTIFICATE AND PRELIMINARY CERTIFICATE}

\begin{tabular}{|c|c|c|c|c|c|c|c|c|c|c|c|c|}
\hline England. & \multirow{2}{*}{\multicolumn{3}{|c|}{$\begin{array}{c}\text { Total Area. } \\
7.4 \text { million acres }\end{array}$}} & \multicolumn{3}{|c|}{$\begin{array}{l}\text { Uncultivated } \\
\text { Land. }\end{array}$} & \multicolumn{3}{|c|}{$\begin{array}{l}\text { Ploughed } \\
\text { Land. }\end{array}$} & \multicolumn{3}{|c|}{ Pasture Land. } \\
\hline East \& N.E. & & & & $1 \cdot 21$ & llion & cres & $4 \cdot 2$ & lio & cres & $2^{\circ} \mathrm{Ol}$ & llio & cres \\
\hline $\begin{array}{l}\text { S.E. and E. } \\
\text { Midland }\end{array}$ & $7^{\circ} 2$ & $"$ & $"$ & 17 & ", & , & $2 \cdot 2$ & $"$ & , & & , & ", \\
\hline $\begin{array}{l}\text { W. Midland } \\
\text { and S.W. }\end{array}$ & 8.0 & ", & " & 17 & " & $"$ & $2 \cdot 1$ & ", & " & $4^{\circ} 2$ & ", & " \\
\hline N. \& N.W. & $9^{\circ} 7$ & ", & " & 35 & ", & $"$ & $1 \cdot 6$ & " & $"$ & +6 & $"$ & $"$ \\
\hline
\end{tabular}

137. What can be learned from the above table concerning the agriculture of each of the four divisions of England? To what causes are the differences due ?

I38. Explain how seasonal changes of warmth and rainfall are indicated by the chief vegetation zones of Europe ?

I39. Bread and butter are two of the principal foodstuffs of civilised man. Show by reference to the great wheat and dairy lands of Europe what physical and climatic conditions are necessary to the production of these articles of diet on a large scale. 
I40. Into what natural regions would you divide either Canada or Australia ? State clearly the principles upon which your division is based.

I4I. What parts of the British Empire lie within the Tropics? What common features and differences of climate and vegetation do they exhibit?

I42. Give an account of the forest regions of Asia, explaining the causes which have produced them. What use is made of the timber which they grow?

r43. Taking Europe and Africa as one land mass, compare its physical features, climatic zones, and characteristic animals and plants with those of the continents of America (North and South).

\section{CHAPTERS XVII. \& XVIII.-HUMAN GEOGRAPHY ; ECONOMIC GEOGRAPHY ; AND MORE GENERAL QUESTIONS}

\section{OXFORD SENIOR LOCAL}

I44. Describe and account for the climate and chief occupations in (a) California, (b) Cuba.

I45. Show how geographical conditions hindered the exploration of Africa.

I46. Describe and account fully for the seasonal distribution of rainfall over the Australian continent. Show how far rainfall determines occupations in the different parts of the Australian Commonwealth.

I47. Divide the United States east of the Rocky Mountains into natural regions.

Describe and account for the climate of the southeast States, and show how far it determines the chief products of the region.

I48. What are the chief requirements for a commercial seaport ?

I49. Give two examples of products which are manufactured at a considerable distance from the source of supply. State fully the conditions under which the raw material is obtained in each case, and the reasons for the position of the manufactory.

I50. Give an example (a) of a region where there is 
a population largely engaged in agriculture; $(b)$ of a region where most of the people dwell in towns. Describe the two regions you select and account for the facts.

\section{OXFORD HIGHER LOCAL}

I5I. Describe fully, and account for, the characteristic features of the equatorial type of climate. Name a large land area where this type of climate prevails. What useful commodities does the area produce?

I52. Give some examples illustrating the fact that a seaport may be either favourably or unfavourably affected by improvements in methods of $(a)$ land transport or $(b)$ sea transport. Discuss the examples you give.

I53. State and explain the conditions which have made south-eastern Asia the habitation of so large a proportion of the human.race.

\section{CAMBRIDGE SENIOR LOCAL}

I54. Describe the delta of the Rhine, giving $(a)$ its position and extent, (b) its physical characteristics, $(c)$ its vegetable products, $(d)$ its towns.

I55. Describe the positions and character of the Llanos, the Selvas, the Pampas, the Falkland Islands, and Lake Titicaca.

I56. Give some account of the Black Earth Region, the Karst, the Landes, the Mer de Glace, the Riviera, the Tyrol.

I57. Describe the following, saying in what parts of Africa examples of each are to be met with :- kloof, oasis, shott, sudd.

How would you account for the increased prosperity of Egypt in recent years?

I58. Describe and explain the origin of $(a)$ the Colorado Cañon, $(b)$ the Chinook Winds, (c) Niagara Falls. Give a brief description of $(d)$ Jamaica, $(e)$ Trinidad.

I59. Write an account of $(a)$ the position and extent, 24 
(b) the climate, $(c)$ the physical features of the desert region of Australia.

I60. Describe the desert regions of America and account for their positions. Name any articles of commerce that are obtained from them.

I6r. What parts of Asia produce (a) tin, (b) tea, (c) silk, $(d)$ camphor, $(e)$ teak ?

I62. Give some account of the position, extent, and character of the deserts of Africa, and explain their origin.

I63. What districts in Africa produce $(a)$ ivory, $(b)$ wine, $(c)$ coffee, $(d)$ wool, $(e)$ cotton ?

I64. From what parts of Central or South America does Great Britain import (a) mahogany, (b) nitrates, $(c)$ rubber, $(d)$ sugar, $(e)$ wheat ?

I65. What is meant by the statement that the Sahara, and not the Mediterranean, really separates Europe and Africa? Support this statement by reference to the climate and productions of Mediterranean Africa.

I66. A population map of the British Isles indicates a dense population in $(a)$ South Staffordshire and portions of adjoining counties, $(b)$ a portion of South Wales. What industries give employment to these large populations in the above districts? Show the connection between the industries and the natural advantages in each case.

I67. What are the most striking features in the river system and coast-line of Australia? Of what races does the present population of Australia consist ? How do you account for their presence there ?

I68. The attraction of the towns, of which we hear so much, is really the attraction of minerals. Consider how far this statement is true, illustrating your remarks by examples from Great Britain and Ireland.

\section{UNIVERSITY OF LONDON : MATRICULATION}

I69. Contrast the climatic conditions on the two sides of the Irish Sea and explain the difference. Point out the chief geographic causes which have influenced 
the nature of the occupations pursued east and west of the sea.

I70. Give instances to show how far the commercial position of a country depends on its productions, geographical position, climate, contour (coastal outline), and relief.

I7I. Point out the chief regions of dense population in England, and in each case show the chief causes to which the density is due.

I72. Compare the situation and configuration of Western Europe and Eastern Asia. Account for the differences in the climate, productions, and trade of the two areas.

I73. Take examples from the United Kingdom to show the relationships existing between the position of large towns and (a) water supply, (b) mineral resources, (c) vegetable products, and (d) transport routes.

I74. Tabulate the principal areas from which the following commodities are obtained:-wheat, maize, steel, salmon, beef. What special facilities are required in the case of each commodity for the carrying on of a large trade?

I75. Divide Russia in Europe into natural regions, and describe briefly the climate, the chief occupations of the people, and the natural products of each region.

I76. Explain what are the most important marks of "Race," and describe the distribution of the chief races in Europe.

I77. State and account for the distribution of textile industries (other than cotton) in Scotland and Ireland.

I78. Discuss the geographic contrasts between the south-east and the north-west areas of the British Isles.

I79. Discuss, with examples, the conditions favourable to the growth of a great port, with examples from Europe.

I80. In what respects can you reasonably compare the British Isles with the Japanese?

$\mathrm{I} 8 \mathrm{I}$. Where in the British Isles is salt found in considerable quantities? How is it obtained? And what industries have grown up in connection with the various " fields"? 
I 82. Describe and compare the past and the present distribution of important wool industries in Great Britain.

I83. Describe the geographical conditions of the Steppe, and show their influence on life there.

I84. Mention four or five areas of dense population in the continent of Europe. State briefly why so dense a population should have gathered in each of the areas you mention.

I85. Explain fully the geographical conditions which have controlled the growth and importance of London.

I86. State the regions or centres in Europe in which silk is $(a)$ produced, and $(b)$ manufactured, in each case giving reasons for the localisation of the industry.

\section{UNIVERSITY OF LONDON : INTER. SCIENCE, ECONOMICS}

I87. Give an account of the distribution of the iron and steel industry of the United Kingdom. Indicate the conditions which have in recent years affected the relative importance of the different seats of that industry, and those which are tending to bring about further changes at the present time.

I88. What are the natural economic regions of Australia, and how far are they controlled by configuration, climate, and facilities for trade?

I89. Show how modern developments in the treatment, handling, and transport of commodities have affected our trade in food products within the last thirty years.

I90. What do you understand by a winter monsoon ? Illustrate from Asia the effects of such a wind on human and plant life.

I9I. Examine the various conditions making for or against the increased use of water-power in the near future.

I92. Indicate the probable "home" of each of three great races,-White, Black, and Yellow,--and show how the climatic factors in each case were favourable to the development of the particular race in the particular area. 
I93. Compare the economic importance of the various areas in the world which have a "Mediterranean" climate.

I94. Give an account of the distribution of iron-ore in Europe, with special reference to $(a)$ output, $(b)$ fuel for smelting purposes.

195. Discuss the distribution of tea and coffeeplanting, taking into account physical features, climatic conditions, labour supply, and access to markets.

UNIVERSITY OF LONDON : INTER. ARTS

I96. What geographical conditions have favoured the localisation of the cotton industry in Lancashire?

I97. Discuss the distribution of sources of power, other than coal, in Eurasia.

I98. Discuss the value of tropical possessions to a State in the temperate regions.

I99. Give an account of the three most important races of Europe, indicating their distinguishing characteristics and the regions now occupied by the races. How far are the people of Britain representative of these races?

200. Describe and account for the typical industries of the following regions :- The Great Karroo, Northern Nigeria, British Guiana, British Columbia.

\section{UNIVERSITY OF LONDON : B.A.}

20I. Discuss instances in which the localisation of manufacturing industries has been largely determined by $(a)$ local supplies of raw material ; (b) local supplies of labour without local sources of power; and $(c)$ a large local market.

202. Describe, in some detail, the morphology of either the Central Plateau of France or of Bohemia and its surrounding highlands, and show how it has controlled the distribution of population.

203. Account for the existence of hot and of cold deserts, and illustrate the effects of each on the character and occupations of " desert" people.

204. What are the fundamental conditions affecting 
the climate of India? And what are their special economic results?

205. What geographical causes have given the United States predominance in the raw-cotton market?

206. Compare the conditions determining the climate of the British Isles with those determining that of Japan, and trace the effects of climate on the economic activities of the two countries.

207. How do you explain the fact that civilisation has developed in Africa to a less extent than in Asia ?

208. Compare the distribution of the rainfall in Australia and New Zealand. Consider the causes of difference, and the chief results on the density of population and the economic activities of the people.

209. Describe the characteristics of an Alpine valley and ridge, paying attention to topographical features, climate, vegetation, and human activities and settlements.

210. Discuss the line of elevation which forms the land edge of the Indo-Pacific basin, with reference to :

(a) Volcanic and seismic phenomena.

(b) Political and economic developments.

2II. Summarise the arrangement of the chief ranges which radiate from the Pamirs. Estimate their relative importance $(a)$ climatic, $(b)$ political.

2I2. Discuss the geographical conditions affecting the position and development of towns, drawing your illustrations from the British Isles and the United States.

213. Examine the utilisation of different types of grassland by peoples at various stages of civilisation.

2I4. Illustrate the control exercised by the Alpine system on human intercourse $(a)$ in past history, $(b)$ at the present day.

\section{NORTHERN UNIVERSITIES: JOINT MATRICULATION}

215. State what you know of the development of the woollen industry in England, and show how geographical conditions have affected its location at different times.

2I6. State the situation of three important manu- 
facturing regions of the former German Empire; in each case name the chief products, and show why the particular industries became important in that region.

2I7. What are the main features of the climate of the temperate grasslands? Explain the causes of such climate, and its effects on (a) the natural vegetation, and (b) the occupations of the people of these regions.

218. State briefly how far geographical conditions have favoured the concentration of so much of the population of the globe in South-eastern Asia and in Western Europe.

219. Name two regions in the United States where each of the following are typical products, and in every case point out the natural advantages for such production:-oranges, tobacco, cotton manufactures, timber, gold.

220. State as precisely as possible the position and extent of the districts which are the most important European sources for the supply of horses, petroleum, iron-ore, and wheat. Explain particularly to what extent climatic conditions or facilities for transport favour these products in each case.

22I. How far do physical features account for the difference of economic development between the east and west of Great Britain ? Compare their influence on such development in the sixteenth and nineteenth centuries respectively.

222. Give some account of the distribution of sugar growing throughout the British Empire.

223. Discuss the effect of climate upon manufactures. Illustrate your answer by reference to the United Kingdom and the Colonies.

224. Give some account of the varying density of population in different parts of British India, and state the causes which account for the greater density in certain districts.

BOARD OF EDUCATION : CERTIFICATE AND PRELIMINARY CERTIFICATE

225. What circumstances have favoured the development on a large scale of the following industries at 
certain centres in North America :-engineering, cornmilling, paper-making, fruit-growing ?

226. Explain the following statement as applied to modern Egypt: "With the Nile regulated and controlled by an immense system of reservoirs and dams; with a fellâhin freed from excessive taxation and given an equitable judicial system; with a network of light railways rendering the produce of the country accessible to foreign markets; Egypt was never more prosperous and its future was never so bright."

227. From the point of view of economic geography, and particularly in relation to import and export trade, compare :

(a) Port Said with Rotterdam.

(b) The Congo with the Danube.

(c) Abyssinia with Switzerland.

(d) Khartoum with Coblenz or Mayence.

(e) Genoa with Port Sudan or Suakin.

228. It is usual to treat the portions of Europe and Africa which border upon the Mediterranean Sea as a distinct geographical region. What characteristics justify this treatment? Illustrate the economic importance of the Mediterranean Sea $(a)$ in the period B.C., $(b)$ in the Middle Ages, $(c)$ since the opening of the Suez Canal.

229. Geography deals largely with climatic conditions and their effect upon man. Show the truth of this statement by contrasting the "geography" of Labrador with that of the Ganges Valley or the "geography" of the Sahara with that of the West Indies.

230. Show how the need for interchange of production has led to the establishment of well-marked trade connections between ports in the British Isles and North America.

23I. Locate the chief industrial areas of Scotland and Ireland : contrast their natural resources, and show how far these explain their respective manufactures.

232. Contrast India with South Africa, or New Zealand with British East Africa, as regards relief, 
rainfall, and natural productions. Give reasons for the contrasts you mention.

233. Arid plains and steppes are found in their greatest extent either in the Trade-wind belts or in vast continental interiors. Wherever they occur, they present the same characteristics of land-surface and natural products, and impose on their inhabitants similar habits and modes of life.

Give reasons for the occurrence of these areas in the regions mentioned; state the characteristics referred to, and show how environment has influenced the homes and settlements of the people.

234. Compare the agricultural products and industries of the Central Lowlands of Scotland with those of the Central Plain of Ireland, in order to show how physical conditions have determined the relative commercial importance of these two regions.

235. During the Middle Ages England was chiefly an agricultural country, but by the end of the eighteenth century had become the leading manufacturing country of the world. What effects did this great change have by the middle of the nineteenth century $(a)$ upon the growth of towns, (b) upon the iron industry, (c) upon the imports of the country?

236. Contrast Iceland with Sicily in respect to relief, rainfall, and natural products. To what causes do you attribute the differences you mention?

237. Write an account of the former Austro-Hungarian Empire, bringing out the physical nature of its component parts and the differences in race of its inhabitants.

238. To what causes would you ascribe $(a)$ the distribution of population in Australia ; $(b)$ the importance of Singapore and San Francisco ; $(c)$ the present influx into the Canadian North-West; and $(d)$ the constantly recurring danger of famine in India?

239. "River valleys tend always to be centres of population." Why is this generally true? Apply the statement to three of the following rivers:-St. Lawrence, Amazon, Euphrates, Indus, Murray, and Yukon. 
- 


\section{GLOSSARY}

Ambas.-Blocks of rocks left by dissection of rivers in Abyssinia ; cf. mesas of Dakota, Colorado, etc. Word of Abyssinian origin. Andesite.-Lava of intermediate composition, i.e. containing about 55-60 per cent. silica; from the Andes, where these rocks are common.

Anthropoid.-Man-like, applied to apes. Greek, anthropos, man.

Anticline.-Applied to stratified rocks; strata curved over in an archlike form. Greek, anti, against; klinō, slope.

Archæan. - Very old (applied to rocks); the oldest rock-system known. Greek, archaios, very old.

Arenaceous.-Sandy ; applied to sedimentary and aqueous rocks.

Argillaceous. - Clayey; applied to sedimentary and aqueous rocks.

Armorican.-A system of earth-folds, and fragments of old mountains in Western Europe. From Armorica, the Roman name for Brittany.

Artesian.-Wells or bore-holes which derive water from a deep syncline ; from Artois, in France, where such wells or bore-holes were first sunk.

Aryan. - A name used to designate a group of Eurasian peoples, and the languages spoken by most of them. From the Sanskrit arya, noble, or of good family.

Asphalte. - Natural pitch, found in Switzerland, Trinidad, etc. Greek and Latin, asphaltos and asphaltum.

Basalt.-Lava of basic composition, i.e. containing less than 55 per cent. silica. The word is one of the oldest in Science, used by Pliny and Agricola ; from Latin basaltes.

Billabongs.-Cut-off lakes, found in the alluvial plains near the Australian rivers ; $c f$. the ox-bow lakes of the Lower Mississippi. Name of Australian origin.

Breccia.-A rock formed of angular fragments cemented together. Of Italian origin ; cf. French brèche, a breach, something broken.

Caatinga.-Tropical thornwood region where the dry season lasts from six to eight months. Thorny bushes and acacias form an important part of the vegetation. Name of South American origin.

Cainozoic.-A group of rock systems; a geological era. Greek, 
kainos, recent, new; zoe, life. Hence, the era of newer or recent life, considered geologically.

Calcareous.-Limey; applied to sedimentary and aqueous rocks. Latin, calc, lime.

Caliche.-A deposit of impure sodium nitrate, $\mathrm{NaNO}_{3}$, found in the dry regions of Chile and Peru.

Cambrian.-A system of rocks. Cambria, the Roman name for Wales. The rocks are well developed in Wales, where they were first thoroughly studied.

Cañons.-Deep, narrow, steep-sided valleys, cut by rivers in approximately horizontal strata. Name of Spanish origin; from caña, a tube.

Carboniferous.-A system of rocks, in Britain and many other regions, containing abundant coal-seams. Latin, carbo, coal, and fero, I bear.

Caribou.-An American variety of reindeer. Word probably of Indian origin.

Cassava. - A starchy food-stuff obtained from the manioc or tapioca plant. French, cassave; Spanish, cassabe.

Chinook. - A warm, dry wind frequently experienced on the eastern side of the Rocky Mountains; cf. föhn, wind of the Alps. Name from Chinook Indians who lived in the Columbia River regions.

Cluses. - Transverse river-gaps cut through the longitudinal folds of the Jura Mountains. Latin, clūsa, clausa, a shut-up place..

Coir.- The husk or outside covering of the coco-nut, used in making ropes, sailcloth, matting, etc. Word of Malay origin; Malay, kayar.

Colza.-A variety of cabbage, the seeds of which, when pressed, yield an oil used for burning. French, colzat; probably from Dutch, kool, cabbage ; zaad, seed.

Copra.-The dried kernel of the coco-nut, the oil having been extracted. Word of Hindustani origin.

Cretaceous.-A system of rocks. Latin, creta, chalk.

Czechs.-A Slavonic people inhabiting Bohemia.

Deciduous. - Applied to trees ; leaves fall in the autumn. Latin, de, down ; cado, fall.

Devonian.-A system of rocks. Name from Devonshire, where the rocks are well developed.

Dolines, dolinas. - Natural funnel-shaped water-sinks found in the limestone of Dalmatia, etc. Word of Russian origin.

Dolomite. - A mineral or rock-constituent composed of calcium and magnesium carbonates. Named after Dolomieu, the French geologist.

Durra.-A species of grain cultivated in India, Arabia, and the Mediterranean lands ; known also as Indian millet, and as Guinea corn. Word of Arabian origin.

Dynamic.-Applied here to pressure as the result of motion; pertaining to motion. Greek, dynamikos, powerful. 
Ecology.-The study of plant life and plant associations as determined by their environment. Greek, oikos, home; logos, speech, discourse.

Eocene.-A system of rocks. Greek, eōs, dawn; kainos, recent.

Equinox.-The time at which the sun crosses the equator (about 2Ist March and 22nd-23rd September). Latin, aquinoctium, aquus, equal ; nox, noctis, night.

Erosion.-Applied to rocks; "eating" or wearing away by frost, rain, rivers, the sea, glaciers, winds, etc. French, éroder; from Latin, $\bar{e}$, out of ; rodere, to gnaw.

Escarpment.-A steep cliff; usually applied to an inland cliff. There is usually a steep face or cliff, and the rocks lie horizontally or with a gentle dip away from it. French, escarper, cut steeply.

Etangs.-Lagoon-like lakes cut off by sand dunes near a coast; especially on north coast of Black Sea. Word probably of Russian origin.

Fiards.-Openings compared with fiords, not so deep.

Fiords.-Long, narrow, deep openings; usually with steep, rocky banks. Type found in west of Norway. Norwegian, fjord.

Föhn. - A warm, dry wind frequently experienced on the northern slopes of the Alpine ranges of Europe. Local name used in the Swiss Alps; possibly from Latin, flavonius. Cf. Chinook wind of Rocky Mountains.

Föhrden.-Branching, shallow openings in the east of Denmark. Name of local origin.

Gabbro.-A basic, plutonic rock, allied in chemical composition to basalt. Name of Italian origin.

Gambier. - A tanning material obtained from the Malay States. Name from Malay, gambir.

Gault. - A clay formation found in the Cretaceous system of Britain. Name of Ėnglish origin.

Geest.-Sandy, dry, and somewhat barren land in the Netherlands. Name of Frisian origin.

Gneiss.-A metamorphic, crystalline rock, having its component minerals arranged in irregular foliæ. German, gneiss; probably an old miner's term.

Haff.-A shallow lagoon or bay inside a long spit of sand on the Prussian Baltic coast. German, haff.

Horst. - A portion of the earth's crust standing above neighbouring portions which have been depressed by faulting. German, horst.

Insolation. - Exposure to the sun's rays ; in modified usage it means effective solar radiation on a part of the earth's surface. Latin; insolation from verb insolo; in, in, and sol, the sun.

Isobar.-A line passing through places which have the same atmospheric pressure. Greek, isos, equal ; baros, weight. 
Isotherm.-A line passing through places which have the same tem. perature. Greek, isos, equal ; therme , heat.

Jurassic.-A system of rocks. The name comes from the Jura Mountains, where rocks of this age are well developed.

Lianas.-Twining tropical plants which climb up the stems and branches of trees in tropical countries. French, lier, to bind.

Limans.-Lagoons on the shore of the Black Sea. Name of Russian origin ; probably from Greek, limen, harbour.

Lithosphere.-The solid part of the earth, as distinguished from the atmosphere and the hydrosphere. Greek, lithos, a.stone ; sphaira, sphere.

Loess.-A pale yellow homogeneous, calcareous loam or clay, or very fine sand. Name of German origin.

Mamelon.-A rounded volcanic hill. French, mamelon, nipple.

Mesas.-Table-lands dissected by rivers in Dakota ; that is, the region is cut up into separate "tables." Spanish, mesa, table.

Mesozoic.-An era of geological time, and a group of rock systems. Greek, mesos, middle ; zo $\vec{e}$, life. Cf. Cainozoic.

Miocene.-A system of rocks. Greek, meion, less; kainos, recent.

Nehrung.-A narrow tongue or spit of land; a long sand-bank on the Baltic coast of Prussia. German, nehrung.

Neolithic.-The later or newer Stone Age. Greek, neo, new ; lithos, stone. Applied to the history of early man as revealed by his weapons and tools.

Oligocene.-A system of rocks. Greek, oligos, few ; kainos, recent. Ordovician. - A system of rocks. Named from the Ordovices, a tribe of ancient Britons who inhabited the region in Wales where these rocks were studied by Lapworth.

Palæolithic.-The earlier or older Stone Age. Greek, palaios, ancient ; lithos, stone. Cf. Neolithic.

Palæozoic.-An era of geological time; and a group of rock systems. Greek, palaios, ancient ; zoē, life. Cf. Cainozoic and Mesozoic.

Pampas.-Treeless, grassy plains in the temperate regions of South America. Spanish, pampa, a plain.

Permian.-A system of rocks. From Perm, in Russia, where rocks of this age are well developed, and where they were studied by Murchison.

Pleistocene.-A system of rocks. Greek, pleistos, most; kainos, recent. Pliocene.-A system of rocks. Greek, pleion, more ; kainos, recent.

Plutonic.-Igneous rocks which have solidified at some depth, and under great pressure. Greek, Pluto, the god of the underworld.

Polyen.-Enclosed valleys in the limestone region of Illyria and Dalmatia. They are usually drained by "water-sinks" in the limestone. Name of local origin. 
Pusstas.-Steppe-like plains in Lower Hungary. Name of Hungarian origin.

Puys.-Conical, volcanic hills in the Auvergne, France. French, appui.

Quader-sandstein.-Quader = square, cubical ; sandstein, German for sandstone. A sandstone in the N.E. of Bohemia which weathers into great cubical blocks.

Rhyolite.-An acid volcanic rock; a lava with a chemical composition similar to granite. Greek, rhyax, stream ; lithos, stone.

Ria.-A river-mouth ; used by Richtofen for a special type of opening. Spanish, ria.

Rift-valley.-A valley let down between two somewhat parallel faults.

Savana or Savanna.-A grassy plain in tropical America; now used for tropical grassy plains with scattered timber. Spanish, savana, sabana.

Schist.-A metamorphic rock that splits into thin irregular laminæ or foliæ. French, schiste; Latin, schistos; Greek, schistos, cleavage or splitting.

Scoria.-Cellular, cindery lava; fragments of lava. Italian, from Latin and Greek, skōria, dung, refuse.

Selvas. - The dense woodlands of the Amazon basin; used for similar equatorial forest plains elsewhere. Latin, silva, forest.

Serpentine.-A mineral or rock consisting chiefly of hydrated magnesium silicate; a much-altered ultra-basic rock; markings supposed to suggest those of a serpent.

Shotts. - Salt-lakes in the Atlas region of North Africa. Name of Arabic origin. Cf. shat, an estuary, Arabic.

Sierra.-Applied to mountain-chains which have a saw-like profile. Spanish, from Latin, serra, a saw.

Sill (igneous).- Used for an intrusive sheet of igneous rock. Remotely connected with Latin, sella, from sedeo, through French, selle.

Silurian.-A system of rocks. Named from the Silures, a tribe of ancient Britons who inhabited the Welsh Borderland, where Murchison studied the rocks.

Sinter.-Material deposited by springs, especially hot springs. Greek, sinter, dross.

Solstice.-The time of the year when the sun reaches its highest declination either north or south of the equator (2Ist June, 2Ist December). Latin, sol, sun; sto, to stand.

Static.-At rest ; opposed to dynamic. Greek, statikos, bringing to rest.

Stratosphere.-The layer of atmosphere some seven or eight miles above the land-surface, beyond which little or no diminution of temperature is supposed to obtain. Latin, stratum, a layer; and sphere, as before. 
Sudd. - A floating mass of vegetation which obstructs the flow of the White Nile. Name of Arabic origin.

Syncline.-Strata dipping towards an axis, in trough-like form. Greek syn, together ; klino, I bend.

Taiga. - The coniferous forest of Russia and Siberia. Name of Russian origin ; now used for such forests elsewhere.

Tchernozoum.-Fertile black soil in S.W. Russia. Name of Russian origin.

Tectonic.-Connected with the building of the earth's crust. Latin, tectonicus; Greek, tektonikos. Greek, tekton, a maker or builder or carpenter.

Terai.-A swampy belt in Northern India, at the foot of the Himalaya. Name of Hindustani origin.

Trachyte.-A lava or volcanic rock of intermediate composition; contains about 60-65 per cent. silica; chemical composition similar to syenite. Greek, trachys, rough.

Triassic.-A system of rocks. Greek, trias, from treis, three. There are three distinct divisions in Central Europe.

Tuff.-Fragmental volcanic matter ejected in explosive outbursts. French, tuf, from Italian, tufa.

Tundra.- The frozen desert plains of Russia, Siberia, and North America. Name of Russian origin.

Váriscan.-Applied to the old, broken and dissected mountains of Central Europe. Variscia, ancient Germany.

Veld (veldt).-The open, pasturage country in South Africa. Dutch, veldt, dry country.

Wadden (watten). - The lagoons behind the sand dunes of the Netherlands. Word of Dutch origin. Cf. old English "wade" and "watter." 


\section{N D EX.}

Aar, I 29, 130.

Aar Gorge, I 12.

Abyssinia, gorges of, 62 .

Acacia bark, 297.

Acid rocks, 10.

Adriatic Sea, 97, I41, 223.

Aiguilles (mountain forms), 30, 75.

Aire Gap, 64.

Akaba, Gulf of, 108, i IS.

Alaska, 23, 32, 5 I.

Alaskan sheep, 314.

Albert Edward, Lake, I IS.

Alcohol, 273.

Aletsch glacier, I 19.

Alfa grass, 254, 306.

Alfa valley, 104 .

Alföld, 96.

Allspice, 286.

Alluvial plains, 78,98 .

Almond, 28 I.

Alpaca, 3 I 6.

Alpine erosion, 30, 3.3.

Alpine man, $33 \mathrm{r}$.

Alpine storm, 26, 34, 36.

Alps, Alpine Mountains, 25, 28, 30, 33, 38, 96, 104, 119,125 , 261,342 .

Alps, Caledonian, 70.

Aleutian Islands, $5 \mathrm{I}$.

Amazon, River, 94, 244.

Ambas, of Abyssinia, 62 .

American, North, plain, 90.

American race, 329.

Amu Daria, River, 89.

Anaconda, 309 .

Anatolia, 38 .

Andalusia, 98, 107.
Andes Mountains, 32, 95 .

Animal life, 307.

Antelopes, 3 IO, 3 I 2.

Anthracite, 7, I 73, 175.

Anthropoid apes, 309, 324 .

Anticline, 25.

Antrim, 45 .

Antwerp, So.

Apennine Mountains, 31 .

Apes, 309, 324.

Appalachian Mountains, 99, I I6, I 58.

Apple, $2 \mathrm{~S}_{5}$.

Apricot, $28_{3}$.

Aqueous rocks, 5 .

Arabian plateau, 38 .

Arachis, 299.

Aragon, 103.

Aral Sea, SS, I I 7, I 68.

Ardennes, I 13, 163.

Arenaceous rocks, 7 .

Argali, 315.

Argiilaceous rocks, 7.

Arkansas, River, 9I.

Arrowroot, 274.

Armorican Mountains, 34, 40.

Artesian wells, 194.

Artificial silk, 293.

Aryan races, 333.

Ash, volcanic, 8, 7 o.

Asia Minor, 38 .

Asphalte, I $8 \mathrm{I}$.

Atlantic coastal plain, 90, 99.

Atlantic coasts, 136 .

Atlantic Mountains, 90.

Atlantic Ocean, I 38 .

Atlas Mountains, 31, 53, 103, I34, 138. 
Alnsosphere, 3, 197.

Australia, I95, 235.

Australian Barrier Reef, I49.

Australian Bight, 236.

Australian plain, 96.

Auvergne Mountains, 46, 49.

Aux Sources, Mont, 62 .

Avernus, Lake, I 24.

Azores Islands, 52.

Bad Lands, Dakota, 39, 6r, 93.

Baffin's Bay, I4I.

Baikal, Lake, I08, I I9.

Baku, 56 .

Balaton, Lake, I 19.

Baltic Sea, 79, 82, 84, I27, I 42.

Banana, 278.

Bandon, River, 105.

Barbary sheep, 315.

Barley, 265.

Barometer, 199.

Bartlett Deep, 143.

Basalt, Io, I2, I 62 .

Basic rocks, Io, 43.

Basins, 102.

Basques, 333 .

Beans, 270.

Bears, 312.

Beech-nut oil, 300.

Beet, 272.

Belchen (Vosges), 37.

Bengal, Bay of, I.35.

Ben Nevis, I20.

Bernese Oberland, IO4, II3, 129.

Betuwe, 243.

Bighorn (sheep), 3 I4.

Bilberry, 286.

Billabongs, 120.

Bison, 308.

Bituminous coal, I73.

Blackberry, 286.

Black currant, 286.

Black Earth region, 86.

Black Forest, 34 .

Black Hills of Dakota, 9I.

Black Sea, 85, 88, I 18 , I2 I.

Blackwater, River, I05.

Block mountains, 34 .

Boa, 309.

Boars, 312.
Bohemia, 38, 40, 46, 63 .

Bombs, volcanic, 44 .

Bonney, Prof., 57, 104.

Boring, Modena, 97.

Bosphorus, I42.

Boundary fault, Highlands of Scotland, 22.

Bowland Fells, 65.

Brahmaputra, River, 99, I I 2, I 5 .

Breccia, 8.

Brienz, Lake, I 29.

British Cotton-Growing Association, 29I.

British Isles, climate of, 214,2 I 9.

Broads of Norfolk, I 2 I.

Brown coal, 7 .

Bruges, 8o.

Buffalo, 3 I I.

Building stones, 156 .

Burnley Basin, I05.

Caatinga, 309.

Cacao, 277, 301 .

Calcareous rocks, 7 .

Calder, River, Lancashire, I03, I05.

Caledonian Mountains, 33, 41, 70, I37.

Caliche, 170.

Camel, 310, 322.

Camels of South America, 315, 323.

Camphor, 302.

Campine (Belgium), 8r.

Campsie Fells, 109.

Canary Islands, 52.

Cannel coal, I73.

Cañons, I IO, II4.

Cantabrian Mountains, I33.

Carbonaceous rocks, 7 .

Carboniferous limestone, 17,63 , 65.

Caribou, 317.

Carpathian Mountains, 31, 54, 86, 96.

Carrots, 272.

Cascade Mountains, North America, 32.

Caspian Sea, 85, 87, I I 7, I68.

Cassava, 274. 
Castle Head, Keswick, 50.

Castor oil, 300.

Catalonian Mountains, I03.

Cattle, 318.

Caucasian race, 329.

Caucasus Mountains, $3 \mathbf{I}$.

Cedars of Lebanon, 305.

Celsius, 24.

Central Valley of Scotland, Iog.

Cereals, 262.

Cevennes, 40, 98.

Ceylon, 233, 277, 279.

Chablais Alps, I 13 .

Chalk, borings in, 26.

Chalk, rock, 16, 25, 73 .

Charas, 293.

Chatt-el-Arab, 9 S.

Chemical industries, 170.

Cherry, 285.

Chestnut, 28I.

Chick-peas, 270.

Chiltern Hills, 25, 74 .

China, 294, 342.

China, climatic type, 213, 217, 255.

Chinook wind, 231.

Christianity, 334.

Chrome leather, 297.

Cinchona, 288.

Cinder cones, 47.

Citron, 281.

Clay, 7, 160.

Cleavage, slaty, $7 \mathrm{I}$.

Cleopatra's Needle, 16r.

Climatic factors, summary, 208.

Cloves, 287 .

Cluses, 105.

Coal, 6, I 7 I, 345.

Coal Measures, 17 .

Coal tar, 295.

Coastal plains, 99.

Coast erosion, $15 \mathrm{I}$.

Coast-lines, 133 .

Coastal openings, 140.

Cockatoos, 309 .

Cocoa, 277, 3 or.

Coco-nut, 279, 301 .

Coffee, 277.

Coir, 279.

Cole, I'rof. G. A. J., 42.
Colorado, i 10.

Columbia plateau, 39 .

Colza oil, 299.

Concordant coasts, I33, 140.

Conduction of heat, 204.

Conglomerate, 6 .

Congo, River, 245.

Coniferous forest, $85,258,305$, 3 II.

Connemara, 164 .

Continental shelf, 99, 140.

Continent-building, 24.

Convection of heat, 204.

Copper, 189.

Copra, 279.

Coral reefs, 148 .

Cork oak, 253.

Coruisk, Loch, 125.

Cotentin, 34.

Cotopaxi, Mount, $48,50$.

Cotton, 290.

Cotton-seed oil, 299.

Cranberry, 286.

Crater, 47.

Crater lakes, I I7, I23.

Craven Fault, 64, 66.

Craven Gap (=Aire Gap), 64.

Crocodiles, 309.

Cross Fell, mountain, 66, I06.

Crustal movements, 24.

Crust blocks, 38, 40, 108.

Crust of earth, $3,22$.

Crystalline schists, I3.

Currants, 282.

Currants, black and red, 286.

Cycle of erosion, 59.

Cyprus Island, 298.

Czechs, 333, 335.

Dakota, Bad Lands of, 39, 61, 93.

Dakota, Black Hills of, 91 .

Dalmatian Coast, 147.

Damson, 284.

Danube, Kiver, 64, 96.

Dardanelles, I 42.

Darwin, C., 23.

Date (fruit), 279.

Davis, Irof. W. M., 68, 75, I10, II 7, 151.

Dead Sea, 108, I18, 168. 
Deccan (India), 99.

Deciduous forests, 86, 258, 305, 3 I2.

de Lapparent, A., 77.

Delta grass, 254, 306.

Deltas, I 29.

Demavend, Mount, 53.

Dent Block, Pennines, 65.

Dent de Morcles, II3.

Dent du Midi, I I3.

Dent Fault, 64, 66.

Dent (tooth), mountain form, 30 .

Denudation, 9, 30, 72, 75, 78.

Derbyshire, gorges of, 63 .

Derwentwater, Lake, I 28.

de Saussure, 75.

Deserts, 340.

Diablerets, Mount, 28, I I3.

Diathermous (air), 200.

Dip-slope, 25, 72.

Discordant coasts, I33, I40.

Dogger Bank, 82.

Dolines, 123.

Dollart See, 82.

Dolomite, I66.

Dolomitic limestone, I66.

Dome, dissection of, 68.

Don, River, 87.

Doubs, River, II 5 .

Dovrefeld, 4I.

Drakensberg Mountains, 62 .

Drave, River, Io4.

Dromedary, 3I I.

Dunes, sand, $8 \mathrm{r}$.

Durra, 268.

Dye-woods, 295.

Dynamic pressure, I 2.

Earthquakes, 22, 55.

Ebony; 304

Ebro, River, I03.

Ecology, 244.

Economic plants, 290.

Ecuador, 248.

Eden, Vale of, 106.

Eifel Mountains, 34, 37, 4I, II3, 163.

Elbe, River, 82.

Elburz Mountains, 31, 38, 53 .

Elephant, 308.
Emu, 310.

Equatorial belt, 2 IO.

Equinox, 203.

Erebus, Mount, 52.

Erie, Lake, 132.

Erosion, 72, 75 .

Erosion by glaciers, 69, 125 .

Erosion, cycle of, 59 .

Erosion in Alps, 30.

Erosion mountains, 58 .

Erosion valleys, I IO.

Erz Mountains, 34, 40.

Escarpment, 26, 72.

Eskimos, 34I.

Esparto grass, 254, 306.

Etangs, 147.

Ethiopian man, 329.

Etna, Mount, 48, 53.

Eucalyptus, 254, 303.

Euphrates, River, 98, 250.

Eurasia, plains of, 78, 89 .

European plains, 79.

Extracts, tanning, 297.

Fairfield Mountain, 68 .

Fall line, 99.

Farina, 266.

Faroe Islands, 45.

Fault valleys, 105 .

Fearnesides, Prot., 69.

Feldberg Mountain, 36 .

Fiards, I44.

Fichtel Mountains, 34 .

Fig, 28I.

Filbert, $28 \mathrm{I}$.

Fingal's Care, 12.

Finland, 14, 41, 84, 125, 127.

Fiords, 107, 145.

Fire clays, I6o.

Fissure-lavas, 8, 45 .

Flagstones, I66.

Flanders, So.

Flavo, Lake, S1. $_{1}$

Flax, 292.

Föhn (wind), $23 \mathrm{I}$.

Föhrden, I 46.

Fold-mountains, 23.

Food plants, 262.

Formosa Island, $5 \mathrm{I}$.

Fox, 316 . 
Frazer River, 39.

Freestone, I 59 .

Frisches Haff, 83 .

Frisian Islands, 82.

Fruits, 278.

Fujiyama Mountain, 48 , 50 .

Furness Abbey, 158 .

Gabbro, Io, 165 .

Gambier, 297.

Ganges, River, 99, I20, 153.

Gas laws, I98.

Gault, 16.

Gazelle, 3 I 2.

Geest, 8 r.

Geikie, Prof. J., 327.

Geneva, I29.

Geneva, Lake, 126, I29.

Geography, definition, I.

Geology, bibliography, 2 I.

Geysers, 56.

Ghats Mountains, to.

Ghent, So.

Giant's Castle, 62.

Giant's Causeway, I2.

Gibraltar, I 4 I.

Gingelly oil, 299.

Ginger, 286.

Girafte, 3 Io.

Glacial erosion, 69, 125.

Glacial mud, 129.

Glen More, I07, I 19.

Glen Roy, 120.

Glens, Highlands of Scotland, 4I, $76,107$.

Gneiss, 13, 67, 162.

Goats, $318,320$.

Gold, 182, 187.

Golden Gate, 104.

Gondwanaland, I39.

Gooseberry, 286.

Gorges, 60, 63, II I.

Gram (cereal), 270.

Grampian Mountains, 35.

Gran Chaco, 95.

Granite, I I, I6I.

Great Glen, 107, I19.

Great Lakes, North America, 90, 132.

Great Salt Lake, Utah, 39.
Great St. Bernard Pass, 31 .

(ireengage, 284 .

Greensand, 16.

Gregory, Prof. J. W., 42, 75, 78, IOI.

Grindstones, 167.

Ground-nut oil, 299.

Guadalquiver, River, 107.

Guanaco, 315 .

Gulf Plain, North America, 90.

Gums, 302.

Gutta percha, 304 .

Haffs, 83, 147.

Hamitic group of men, 333 .

Harker, Dr. A., 57, 125.

Harz Mountains, 34 .

Hawaii, 46.

“I Ieidelberg jaw," 325.

Heligoland, $15 \mathrm{I}$.

I Ielvellyn Mountain, 68.

Hemlock, 297, 305.

Hemlock-spruce bark, 297.

Hemp, 293, 300.

Hemp-seed oil, 300.

Henequen, 293.

Herculaneum, 8.

Hickory nut, 282.

IIighlands of Scotland, 34, 41, 76, 125.

Himalaya Mountains, $31,33,38$, I 12, I $15,233$.

Hindu Kush, 32, 38, 88 .

Hippopotamus, 309 .

Hoang-ho, River, 6o, 143.

I Hobbs, Prof. W. H., 42, I 17.

Holderness, coast of, I 50.

Homer, 285.

"Horn," Alpine mountain name, 3 .

Horses, 308, 311, 322.

Horst, 35 .

Hot springs, 40.

Houses of Parliament, I 59.

Hudson Bay, 90, I4I, I44.

Humming-birds, 309.

Hungarian Plain, 37, 96.

Hungarian Sea, 37 .

Hunsritick, 34, $4 \mathrm{I}$.

Huron, Lake, I 32 . 
Huxley, Prof. T. H., 325.

Hydrosphere, 4, 197.

Hyana, 3 IO.

Ibex, 315 .

Iceland, 45, 52, 56, I 22.

Idaho, 45 .

Igneous rocks, $7,186$.

India, climate of, 217, 23I, 245, 247.

Indian Ocean, 137.

Indigo, 295.

Indo-Gangetic plain, 98.

Indus, River, 98, I I 2, I I 5, 250.

Ingleborough Mountain, 66.

Insolation, 201.

Intermediate igneous rocks, Io.

Intermont plains, 96 .

Intrusive igneous rocks, 9 .

Iquitos, 95, 246.

Iran plateau, 38 .

Irish elk, 327.

Iron ores, I84.

Irrawadi, River, I04.

Isothermal maps, 212, 22 I, 224.

Izalco, Mount, 48.

Jade Bay, 82.

Jaguar, 308 .

Jan Mayen, Mount, 52.

Janina, Lake, I 23.

Japan, I 5, 32, 294.

Japan Sea, 35 .

Jarrah tree, 305 .

Java Island, 32, 47, 53 .

Jordan, River, Io8.

Torullo, Mount, 48 .

Judaism, 334 .

Tudd, Prof. J. W., 54, 57.

Jukes, J. B., 105.

Jukes-Browne, 76 .

Jura Mountains, 27, 63, 72, 105, I 16.

Jute, 293.

Kaiserstuhl, 36 .

Kalahari, 240, 245.

Kamchatka, 32, 5 I.

Kansas, River, 9I.

Karakorum Mountains, 38 .
Kara Kum, 89.

Karoo, 257.

Karst, I23, I 47, 223.

Kashmir, 321.

Kauri gum, 302 .

Kendall, Prof. P. F., I29, 327.

Kenia, Mount, 54 .

Khorassan Mountains, 88.

Kilauea, Mount, 46.

Kilimanjaro, Mount, 55 .

Kiolen Mountains, $4 \mathrm{I}$.

Kisil Kum, 89.

Kopet Dagh Mountains, $3^{8}$.

Korea, 35, 214.

Krakatoa, 53 .

Kropotkin, P., 312.

Kuen Lun Mountains, 38 .

Kurdistan Mountains, 38 .

Kurile Islands, $5 \mathrm{I}$.

Kurisches Haff, $8_{3}$.

Laacher See, I 24.

Labrador, 4I.

Ladoga, Lake, 127.

Lagoons, 80, I21, 146.

Lake District, England, 65, 68, I06, I19, 125.

Lakes, II7, I29, I32.

Lamplugh, G. W., 327 .

Landes, I 2 I.

Land-forms, 22.

Iapilli, 44 .

La Plata River, 94.

Lapps, 34I.

Larch-bark, 297.

Latent heat, 206.

Laurentian climate, 215.

Laurentian plateau, 4I, 93, 125.

Laurvig, 16r.

Lava, 7,45 .

Lava cones, 45 .

Lead, 190.

Lee, River, I05.

Leguminous plants, 270.

Lemon, 28 I.

Lentils, 27 I.

Lentisk, 29 S.

Leopard, 308.

Lianas, 245.

Libreville, 247. 
Ligurian Sea, I4I.

Limans, 146.

Lime (fruit), $28 r$.

Limestone, 6, 17, 158, 166.

Linen, 292.

Linnæus, 24.

Lion, 3 Io.

Linseed, 292, 300.

Linseed oil, 300 .

Lisbon, earthquake, 55.

Lithosphere, 3.

Llama, 316.

Llanos, 95.

Loess, 5, 6o, 86.

Lombardy, Plain of, 37, 97, 343 .

London, 345 .

London Basin, 26.

London Bridge, I6r.

Loo Choo Islands, $5 \mathrm{r}$.

Lorne, Firth of, 107.

Lorraine, 183.

Lucerne, Lake, 28 .

Liineberg Heath, 83 .

Lyde, Prof. L. W., 100.

Lyell, Sir C., 13, 47, 91, I53, 155 .

Lynx, 311.

Macaroni, 265.

Macaws, 309.

Mackenzie River, 9I.

Mackinder, H. J., 100.

Madagascar Island, 239.

Magnesian limestone, I 59.

Magnetite, 186.

Magyars, 335 .

Mahogany, 304 .

Maize, 266.

Malar, Lake, 127.

Malaysia, 32, 138 .

Malt, 265 .

Mamelons, 46.

Man, antiquity of, 324 .

Manchester, a trade centre, 265, 344.

Mangrove swamps, 150.

Manilla hemp, 293.

Manitoba, 93 .

Manych depression, 87 .

Marble, 163.
Marine denudation, plain of, 78 .

Marjeelen See, II9.

Markhor (goat), 315.

Marr, Prof. J. E., 42, 68.

Masurian Lakes, 83, 86.

Maté, 278.

Matra, 54.

Matterhorn, 30 .

Mauna Loa, Mount, 46.

Mediterranean climate, 213, 252.

Mediterranean man, 330.

Mediterranean region, 222.

Mediterranean Sea, 54, I I7, I 40.

Mekong, River, I04.

Memel, River, 82.

Mendips, gorges of, 63 .

Mercalli, 50.

Merino sheep, 319.

Mersey, River, 170.

Mesas, 62.

Meseta (Spain), 34, 40, 98, 137, 188.

Mesopotamia, $9 \delta$.

Metamorphic rocks, 12, 162, 187.

Meteorology, $19 \$$.

Meuse, River, 8o, II 3 .

Mexican plateau, 39 .

Mexico, 47, $5 \mathrm{I}$.

Mexico, Gulf of, 99.

Michigan, Lake, I 32.

Midland Valley of Scotland, 23, I09.

Mill, Dr. H. R., I, 86, 100.

Miller, Hugh, 157.

Millet, 268 .

Millstone grit, 66, I3 I, I66.

Mineral springs, 194.

Minnesota, 92.

Mississippi, River, 91, 105, 140, $153,267$.

Missouri, River, 91 .

Mohair, 321.

Mohair goat, 255, 3 I I .

"Monadnocks," 67.

Mongolian man, 329.

Monsoon climate, 216, 247 .

Monsoon lands, 309 .

Mont Aux Sources, 62.

Mont Blanc, 30, 75 .

Mont St. Michel, 50. 
Monte Nuovo, 47.

Moraines, glacial, 82.

Moray Firth, 107.

Morvan plateau, 35 .

Mouflon, 3 I 5 .

Mountain-building, 24.

Mountain-rims of plateaux, 40.

Mulberry, 294.

Mull Island, 45.

Munkacs, 54.

Murchison, Sir R., II 5.

Muscatels, 282.

Musk ox, 317 .

Natal, 62.

Neanderthal skull, 325 .

Necks, volcanic, 9,50 .

Nehrungs, 83 .

Neolithic man, 262, 326.

Netherlands, 80.

Neutral coasts, I 35 .

Nevada, 108.

Newfoundland, 138 .

Newlands Beck, I 28.

New Zealand, 51, 56, 145, 237.

New Zealand Alps, 32.

Nile, River, 250, 343.

Nomads, 339.

Norfolk coast (England), I 50.

North Downs, 26, 72, 74 .

North Sea ice-sheet, 82 .

Norway, changes of level, 24 .

Norway Deep, 127.

Nutmegs, 287.

Nyassa, Lake, I08, I18, 124.

Oak-bark, 297.

Oasis, 250.

Oats, 266.

Ob, Valley of, 87.

Ochil Hills, I09.

Ohio River, 92.

Oil-cake, 292, 299.

Oil-fields, I79.

Oil-shales, I8r.

Oldenburg Marsh, 82.

Olive, $254,283$.

Olive oil, $283,298$.

Onega, Lake, I27.

Ontario, Lake, I32.
Opium, 287.

Orange, 280.

Oregon, basin of, 45, IoS.

Ores, of metals, 181 .

Urganic rocks, 6.

Orinoco, River, 94.

Ornamental stones, 162.

Ostrich, 3 IO.

Ox, 3 II.

Ox-bow lakes, 91, I 20.

Ozark Mountains, 91.

Pacific coasts, 136.

Pacific Ocean, I36, 138.

Palæolithic P'eriod, 326.

Palm-kernel oil, 301 .

Palm oil, 301.

Pamir Mountains, 38 .

Pampas, 94, 256, 307, 313.

Paper-making, 306.

Para, 246.

Paradise, bird of, 309 .

Paraffin, i8o.

Paraguay tea, 278 .

Parallel Roads of Glen Roy, 120.

Parasitic cones, 49.

Paris basin, 73 .

Paving-stones, 164 .

Peach, 284.

Pears, 285 .

Peas, 270.

Peat, 6, I7I.

P'echili, Gulf of, 140.

Pelée, Mount, 52.

Peneplain (peneplane), 4I, 75, 78 .

Pennine faults, 64, 66, 106.

Pennine Mountains, $65,158$.

Penygent Mountain, 66.

Pepper, 286.

Persian Gulf, 98, I34, I37, I40.

Peruvian bark, 288.

Petrographical provinces, 54 .

Petroleum, I78, 346.

Philippines, Islands, $5 \mathrm{I}$.

Phosphorus, I 83 .

Pickering, Vale of, 103, 105.

Pig, 308, 321 .

Pig-iron, 191 .

Piltdown skull, 325.

Pimento, 286. 
Pineapple, 279.

Pines (and see Taïga), 305.

Pipes, igneous, 9.

Pithecanthropus, 325 .

Piz, mountain form, 30 .

Plains, 78 .

Plants, economic, 290.

Plateau de Langres, 73.

Plateau, Great Lakes, 90.

Plateau-lavas, 8,45 .

Plateaux, 37.

Plateaux of North America, 91 .

Platinum, I82, I84.

Plugs, of volcanoes, 50 .

Plums, 284.

Plutonic rocks, Io.

Po, River, 97, I 2 I.

Poland, I 70.

Polar bear, 316.

Polyen, 123.

Pompeii, 8.

Pontic Mountains, 38 .

Popocatapetl, Mount, 48.

Potatoes, 272.

Prairie, 86, 91 , 3 I 2.

Pressure of atmosphere, 198.

Pripet, marshes of, 86 .

Prunes, 284.

Puget Sound, I04, I 34 .

Pulses, 270.

Pumice, 44.

Punjab, 233.

Pusstas, Hungary, 97.

Puys, Auvergne, 40.

Pyramids of Egypt, I6o.

Pyrenees Mountains, 133.

Quader-Sandstein, I I 2.

(Uuebracho, 297.

(uinine, 288.

Yuito, 248.

Rabbit, 308.

Radial movement, 24 .

Radiation, 204.

Raft lakes, I22.

Railway-towns, 350.

Raised beaches, I54.

Raisins, 282.

Ramie, 293.
Ramsay, Sir A. C., I25.

Rape-oil, 299.

Raspberry, 286.

Red-currant, 286.

Red Sea, 54, 108.

Regional folding, 70.

Reindeer, 316,323 .

Religions, 334, 336.

Renfrew Heights, I09.

Residual niountains, 66.

Resin, 302.

Reuss, River, II2.

Rhea, 293.

Rhine, floods of, I 30.

Rhine, river and valley, 3 I, 35, 55, IO3, IOS, I I 2, I 30.

Rhinoceros, 309.

Rhön Mountains, 34 .

Rhone, river and valley, 28, 30, 98, I03, I I 2, 129.

Rhyolite, IO, 46.

Rias, I 44 .

Ribble, River, I I 5.

Ribblesdale, 66.

Rice, 268.

Richthofen, von, 60, I44.

Riesen Mountains, 34, 40.

Riff coast, I34, I 4 I.

Rift valleys, 35, 54, I O2, I05, I I 3 .

Road-metal, 164 .

Rock-salt, I 68.

Rock-systems, I 8.

Rock tarns, 124.

Rocky Mountains, 39, 45, 93, 105.

Root crops, 27 I.

Rosewood, 304.

Rowley Rag, 166.

Royal Commission on Coast Erosion, I $5 \mathbf{I}$.

Rubber, 303.

Rudolf, Lake, 54, Io8, I I8.

Riigen, Island of, 83 .

Rumanians, 336.

Russell, Prof. I. C., 245.

Russian Plain, 84.

Kussian Platform, 84 .

Rye, 266.

Sacramento River, IO4. 
Sago, 273.

Sahara, 245, 249.

St. Lawrence, Lakes of, 126.

St. Michel, Mont, 50.

St. Vincent, Gulf of, 109.

Salt lakes, I27.

Salt Lake, Utah, 39, I 19, 168.

Salwen, River, I04.

Sand deserts, 89 .

Sand dunes, 8r.

Sandwich Islands, 46.

Saone, River, I30.

Sarakamych depression, 88.

Sardinia Island, 37 .

Savana, 25I, 309.

Save, River, I04.

Saxolny, 63.

Scafell Mountain, 68.

Scandinavia, I4, 4 I.

Scheldt, River, 80.

Schemnitz, 54.

Schists, I3, 67, 162 .

Schollenen gorge, I1 2.

Schyn gorge, I12.

Scoria, 47 .

Scotch pine, 305.

Scotland, Highlands of, 125, 176 .

Scutari, Lake, 123.

Sedimentary rocks, 4,6 .

Selvas, 307 .

Semitic group of men, 333 .

Sequoia, 254.

Serapis, Temple of, 154 .

Serpentine, I63.

Sesame oil, 299.

Shale, 7, 160.

Shasta, Mount, 50.

Shatt-el-Arab (Chatt-el-Arab), 98.

Shea-butter, 30r.

Sheep, 3II, 3I3, 3I 8 .

Shotts, I03.

Siberian plain, 87 .

Sidlaw IHills, rog.

Sierra Morena, 40, 98.

Sierra Nevada, 30, 32, 53, 98, 104.

Sierras, 25, 30.

Silesia, 54 .

Silica, Io.

Silk, 294.
Sills, igneous, 9 .

Silver, 189.

Simplon Pass, 31 .

Sinai, Mount, 35.

Singapore Island, 274.

Sisal hemp, 293.

Slate, $7,160$.

Slaty cleavage, $7 \mathrm{I}$.

Slavonic man, 332, 335 .

Sloths, 308.

Smith, Wm., 17.

Snag Lake, 122.

Snowdon Mountain, 8, 69, 7I, 125.

Soap-making, 298, 301 .

Sodium nitrate, 170 .

Solstice, 202.

Solution lakes, I17, 122.

Somma, Mount, 49, I24.

Soufrière, 52, 124.

South America, plains of, 94 .

South Downs, 26, 72.

Soya beans, 271.

Spencer Gulf, Iog.

Spices, 286.

Springs, 192.

Squirrel, 3 II.

Stabix, 8.

Staffa, I 2.

Starch, 267, 273.

Stassfurt, salt deposits, I69.

Static pressure, I2.

Steppes, 86, 312.

Stratosphere, 202.

Strawberry, 286.

Stromboli, Mount, 53.

Submerged forests, 154 .

Sudd (of Nile), I 22.

Suess, Prof. E., I39, I 55.

Sugar-beet, 272, 275.

Sugar-cane, 274 .

Sulaiman Mountains, 38 .

Sultana, 282 .

Sumach, 297.

Sumatra Island, 32, 53.

Sunda Strait, 53.

Swede (turnip), 27 I.

Synclinal valleys, 102.

Syncline, 25.

Syr Daria, River, 89. 
Taïga, 258, 3 I I.

Tanganyika, Lake, ı08, i 8 .

Tangential movements, 24, 28.

Tanning materials, 297.

Tapioca, 274.

Tapir, 308.

Tarn, gorges of, 63 .

Tasmania, 238.

Tasmanian natives, 328 .

Taunus Mountains, 34, 4 I.

Taurus Mountains, 38, I08.

Tchad, Lake, I 18.

Tchernozoum, 86, 92.

Tea, 276.

Teak, 304.

Tectonic valleys, Io2.

Teleki Mountain, 54 .

Teneriffe Mountain, $48,50$.

Terai, 234.

Terror, Mount, 52.

Teschen, 54.

Thar Desert, 234.

Thames Basin, 26.

Theiss, River, 96.

Thian Shan Mountains, 38,88 .

Thibet (Tibet), 342.

Thirlmere, Lake, I25, I3I.

Thornwood, $25 \mathrm{I}$.

Thuringer Wald, 34 .

Tiberias, Lake, 122.

Tibet (Thibet), 342 .

Tibetan Himalaya, I I 5 .

Tierra caliente, 2 I I, 229.

Tierra del Fuego, 52.

Tierra fria, 2 I I, 229.

Tierra helida, $2 \mathbf{1} \mathbf{1}$.

Tierra templada, 2 I I, 229.

Tiger, 308.

Tigris, River, 98.

Timan Mountain , 85, 90.

Timber, 304.

Tin, 190.

Tin-stone, I 84 .

Titicaca, Lake, 39.

Tobacco, 287.

Tödi Alps, I 13.

Tornadoes, 230.

Torridonian Mountains, 67.

Torridon Sandstone, 157.

Towns, location of, 339,347 .
Trachyte, 165.

Trade winds, 212.

Trans-Siberian Railway, 88.

Transylvania, 54 .

Trient, gorge of, II 2.

Tuff, igneous, $8,44, \mathrm{I} 62$.

Tugela, River, 63 .

Tulare, Lake, 104.

Tundra, 85, 90, 136, 215, 260, 316,340 .

Turkestan, 89 .

Turkoman, Desert of, 89 .

Turnip, $27 \mathrm{r}$.

Turpentine, 302.

Tyrrhenian Sea, 23, 37, I4I.

Uganda, climatic type, 245, $24 \mathrm{~S}$.

Ural Mountains, $8_{5}$, $\$ 8$.

Urial (sheep), 315 .

Ust Urt plateait, 90 .

Utah, Basin of, Io\&.

Valdai Hills, $8_{4}$.

Vale of Pickering, 103, 105.

Valleys, I02, 114.

Valloni, I 48 .

Vanilla, 287.

Van, Lake, 169.

Variscan Mountains, 34, 40.

Vaseline, I So.

Vegetable oils, 298.

Veld, 257.

Veluwe, Netherlands, S2, 243.

Vermicelli, 265 .

Vesuvius, Mount, $8,4 S, 53$, I24.

Via Mala, I 2.

Victoria plum, $2 \mathrm{~S}_{4}$.

Vicuña, 315 .

Vine, 254.

Volcanic ash, 160.

Volcanic rocks, 7 .

Volcanoes, 43, 45, 55 .

Volga, River, 86.

Vosges Mountains, 34, 41, 73 .

Vulcanising rubber, 303 .

Wadden, So, I 47.

Waes, or Wass, So.

Walnut, 28I.

Washington, State, U.S.A., 45. 
Wass, or IVaes, 8 .

Wastdale, 69.

Wastwater, Lake, 69.

Water-power, I77.

Water supply, r9I.

Water vapour in the air, 199.

Weald, 26, II 5, I 84 .

Wener, Lake, I27.

Weser, River, 82.

Westerwald, 34, 1 I 3 .

West Riding of Yorkshire, gorges of, 63 .

Wetter, Lake, 127.

Whalley Gap, 103.

Wharfedale, 66.

Wheat, 263.

Wheat harvests, 264 .

Whernside, Great, mountain, 66.

Whirlwinds, 230.

White River of Dakota, 39.

White Sea, 127, 142.

Wild ass, 310.

Wind-gaps, 74 .
Vine, 282.

Woad, 296.

Wolf, 313, 316.

Wood-pulp, 306

Woodward, Dr. A. S., 325.

Yang-tse-Kiang, River, 104, II2, 143.

Yellow River, 60.

Yellow Sea, I 43.

Yellowstone Park, 56.

Yenisei, River, 87.

Ypres, 80.

Yukon, River, 39.

Zabern Gate, 73.

Zagros Mountains, 38, 98, 139.

Zebra, 3 Iо.

Zebu, 3 II.

Zinc, 190.

Zinc ore, 186.

Zuyder Zee, 81 . 


\section{BELL'S GEOGRAPHICAL SERIES}

EDITED By ALBERT WILMORE, D.Sc.(Lond.), F.G.S.

\section{THE BRITISH EMPIRE BEYOND THE SEAS}

\section{AN INTRODUCTION TO WORLD GEOGRAPHY}

BY

MARION I. NEWBIGIN, D.Sc.(London)

With upwards of zo Maps and Diagrams. Third Edition. 4 s. 6 d.

Intended for use in upper and middle forms, where a rudimentaryacquaintance with world geography and more detailed study of the British Islands may be assumed. In apportioning space to the different regions their importance as types has been so far as possible kept in view. Further, the human side has been kept in the forefront, an attempt having been made throughout to answer such questions ashow do people live? to what climatic conditions are they exposed? what crops do they grow? and so forth, in the different areas considered. Finally, it will be noticed that statistics, especially those relating to trade, have been employed to a somewhat greater extent than is usual in an elementary book. They have been inserted to facilitate comparisons between the different regions of the globe, and to give vividness to such comparisuns.

Educational News: "Dr. Newbigin is now recognised as one of our foremost authorities on geography, and has produced a stimulating book. We cordially commend it to those teachers who desire a manual that will afford much food for reflection and that will vitalise their teaching." 


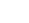





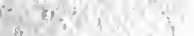




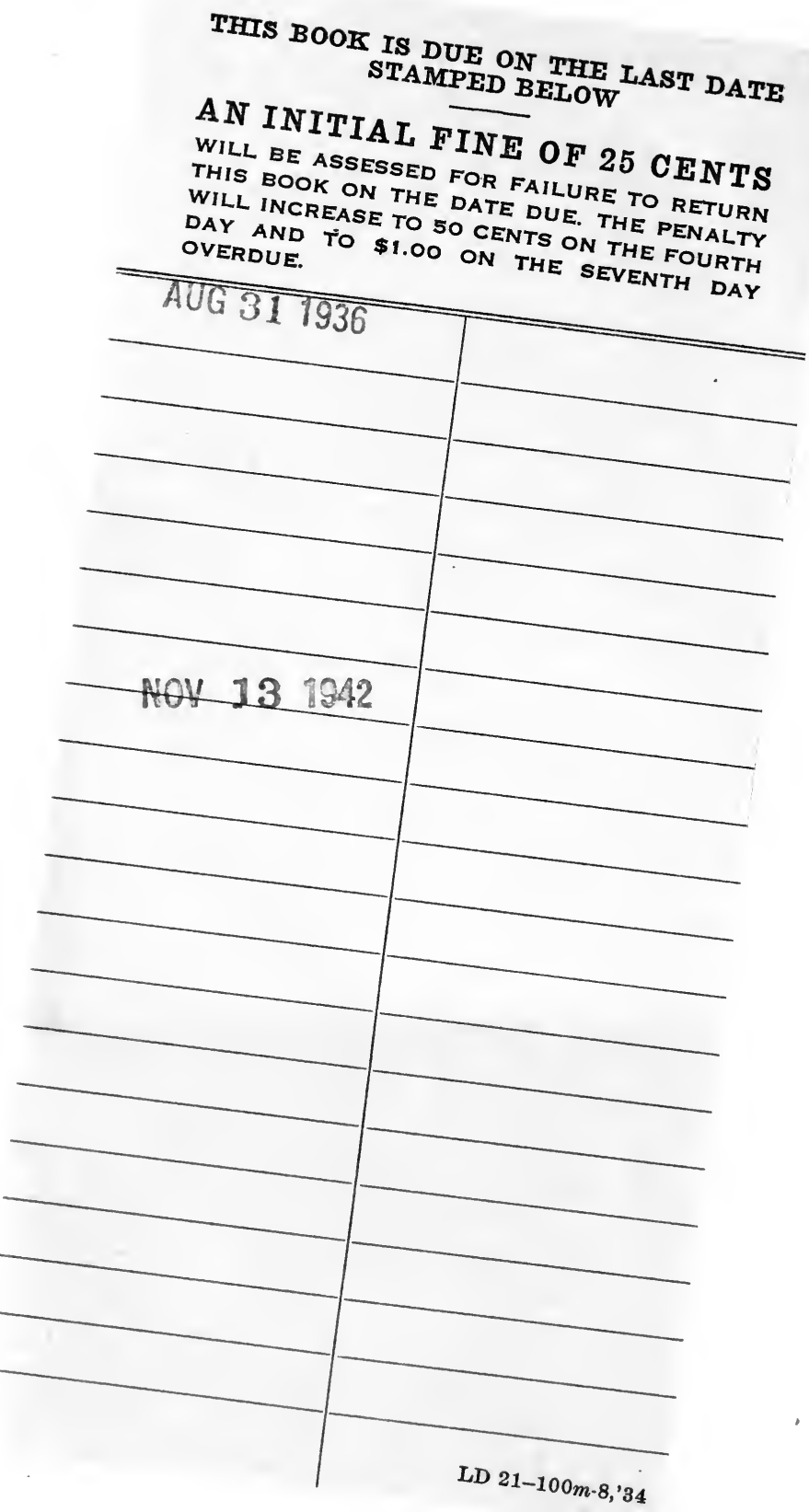


YB $0,270 ́$

GB55

$W_{5} \quad 42341$

UNIVERSITY OF CALIFORNIA LIBRARY 
